\title{
Coping with Emigration in Baltic and East European Countries
}

BALTIO MOBILITY MIGRATI INTRA EU MOBILITY MICRTION DIASPORA MIGRATION DIASPORA BAL

MIGRATION POLICY DIASPORA INTRA EUTIU POLICY INTITY MIGRATION PORA MIGRAIUUIN INTRA EU MUDIIC COUNTRIILO MIGRATION POLICY INIES INTRA EU MOBILITYIES DIASPORA MINTIE COUNTIC COUNTRIES INITY BALTIC COUN DIASPORA BALTIC COUN POLICY INTRA EU MOLICICY DIAS

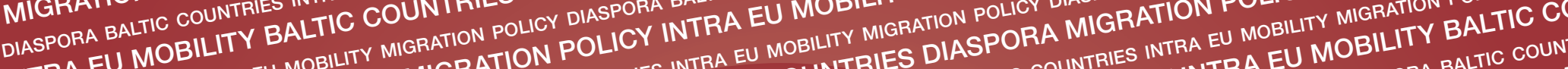
INTRA EU MOB INTRA EU MOBILITY MICRA MIGRATION POLICY INTRA EU MOBILTY INTRA EU COUNTRIES DIASPALTIC COUNTRIES INTRA EU INTRA EU MOBILITY BALTIC COU BALIC COUN

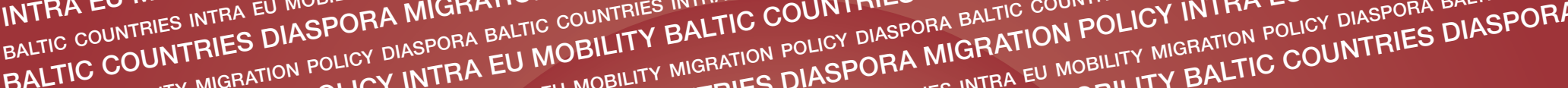

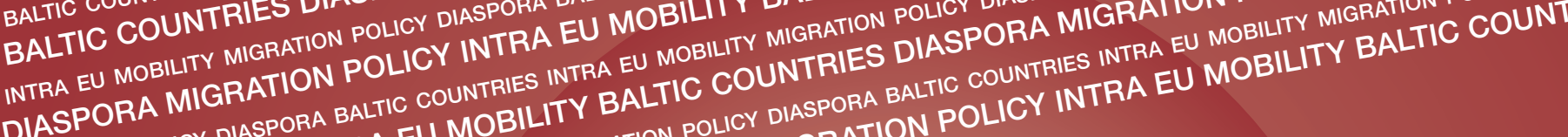
MIGRATION POLICY DIASPORA BALTIC COUNTE MOBILITY BALTIC OLICY INTRA MOLICY DIASPORA BALTIC COU IC DIASPORA BALTIC COUNTRIES INTRA EU MOBILTYRIES DIASPO BALTIC COUNTRIES INTRA EU MOBILITY INTRA EU MIOBITY MOBILITY BALTIC COUNTRIES INTRA EU MOLICY INTRA EU MOE TIC COUN

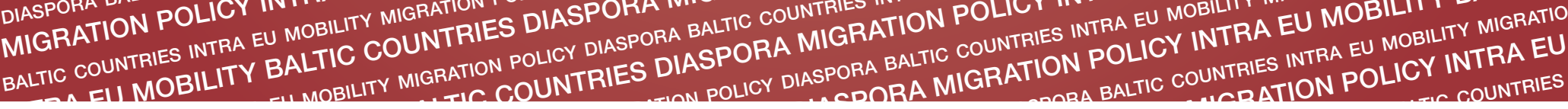

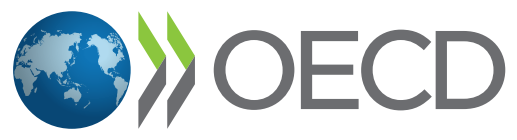





\section{Coping with Emigration in Baltic and}

East European Countries 
This work is published on the responsibility of the Secretary-General of the OECD. The opinions expressed and arguments employed herein do not necessarily reflect the official views of the Organisation or of the governments of its member countries.

This document and any map included herein are without prejudice to the status of or sovereignty over any territory, to the delimitation of international frontiers and boundaries and to the name of any territory, city or area.

Please cite this publication as:

OECD (2013), Coping with Emigration in Baltic and East European Countries, OECD Publishing.

http://dx.doi.org/10.1787/9789264204928-en

ISBN 978-92-64-20491-1 (print)

ISBN 978-92-64-20492-8 (PDF)

The statistical data for Israel are supplied by and under the responsibility of the relevant Israeli authorities. The use of such data by the OECD is without prejudice to the status of the Golan Heights, East Jerusalem and Israeli settlements in the West Bank under the terms of international law.

Corrigenda to OECD publications may be found on line at: www.oecd.org/publishing/corrigenda.

(c) OECD 2013

You can copy, download or print OECD content for your own use, and you can include excerpts from OECD publications, databases and multimedia products in your own documents, presentations, blogs, websites and teaching materials, provided that suitable acknowledgment of the source and copyright owner is given. All requests for public or commercial use and translation rights should be submitted to rights@oecd.org. Requests for permission to photocopy portions of this material for public or commercial use shall be addressed directly to the Copyright Clearance Center (CCC) at info@copyright.com or the Centre français d'exploitation du droit de copie (CFC) at contact@cfcopies.com. 


\section{Foreword}

Emigrants are increasingly seen as a key resource to support long-term economic growth in their countries of origin, not only providing remittances but contributing to development through investment, exchange, and intensification of networks. The worldwide stock of migrants has grown to comprise $3 \%$ of the world population, accounting for more than 232 million people in 2013. The notion of "diaspora" often includes descendants of migrants and more generally persons who maintain ties of some kind with a specific country of origin in relation to their migration background. This makes a broad pool of resources on which countries can draw.

How to gain from emigration is a pressing question in countries which are undergoing large emigration. The Baltic countries, Estonia, Latvia and Lithuania, are a prime example of countries where recent emigration has drawn the attention of policy makers looking to mitigate potential negative impacts of the departure of young and skilled emigrants as well as to support economic development. The latter two countries in particular saw outflows rise after accession to the European Union and peak during the severe recession in which began in 2008. These outflows, which have disproportionately involved young people, exacerbate a demographic situation in which Baltic countries face a rapidly ageing population and receive few immigrants themselves.

This publication underlines how the diasporas of each Baltic countries is far from homogeneous, consisting of individuals with different emigration histories, expectations, skills, degrees of attachment to the country of origin and of integration in the destination country. Designing policies which respond to such a heterogeneous and rapidly changing group is particularly challenging. It requires, as a first step, to have a sufficiently detailed and accurate picture of population groups in question, as well as an assessment of future labour market and skills needs. This is a prerequisite for providing them with more specific and targeted information on economic opportunities.

To shed more light on these issues, the OECD co-organised, with the Latvian Ministry of Foreign Affairs, on 17 December 2012 a conference on the economic impact of emigration, exploring the challenges and policy implications of emigration in the Baltic countries. This was the first time that policy makers in the region came together to discuss the evidence on emigration and its impact, and to exchange their experience with representatives of OECD countries with longer experience of emigration and diaspora relations.

This publication compiles the material developed and discussed at the joint seminar. It takes stock of the current knowledge of emigration from Central and Eastern Europe, including the characteristics of past and present emigrants, their tendency to return or to remain abroad, and the economic impact of this movement on the origin country. It is well known that remittances from emigrants may act as a buffer during a recession in origin countries, but there are other effects on the labour market which are more ambiguous, including changes in the skill composition. 
The publication also identifies policy instruments which have been put in place in OECD and other countries to engage diasporas. This appears particularly important, as recent emigrants are not all likely to return to the Baltic countries, and patriotism alone does not seem to be sufficient to keep ties. Even when migrants do not return to start businesses or put their knowledge to work in their origin country, there are still other means to keep them engaged, financially, scientifically or in entrepreneurial networks.

It was clear from the participants in the conference that there is no single institutional recipe for engaging diasporas and benefiting from emigration, but these countries have taken important steps to ensure that their citizens abroad are considered in policy developments at home.

It is our hope that this publication will contribute to a better understanding of the impact of emigration on countries of origin, and to help structure policies to increase positive impact and cushion any negative impact. 


\section{Table of contents}

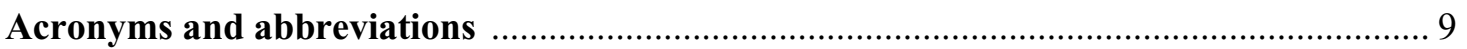

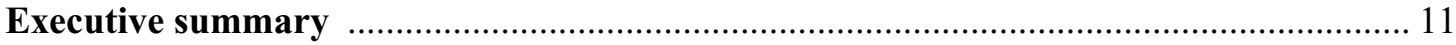

Chapter 1. Emigration from the Baltic States: Economic impact and policy implications ....13

By Godfried Engbersen and Joost Jansen

Introduction

Migration flows from the Baltics: The extent of migration and migrant

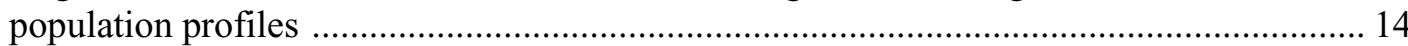

The economic impact of emigration on the Baltic States, Poland and Romania ................ 16

In pursuit of successful diaspora policies: Baltic initiatives and experiences

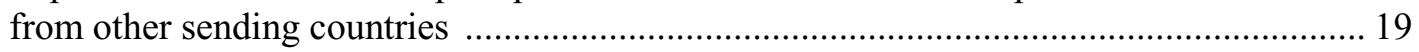

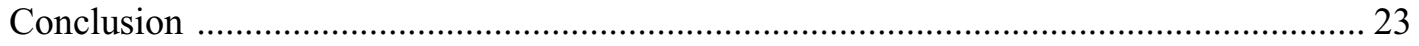

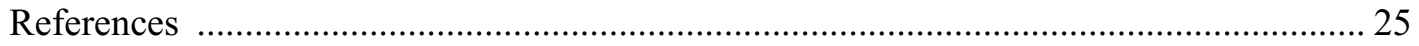

Chapter 2. Emigration from Estonia: Recent trends and economic impact ................... 29

By Veronika Kaska

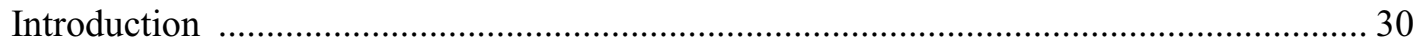

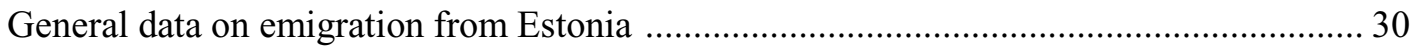

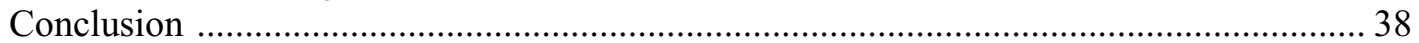

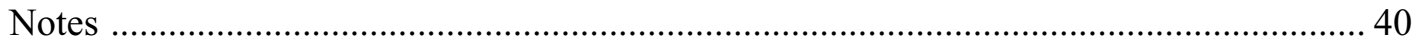

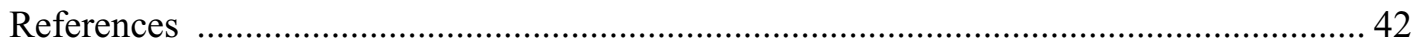

Chapter 3. The social and economic impact of emigration on Lithuania ........................ 45

By Audra Sipavičienè and Vlada Stankünienè

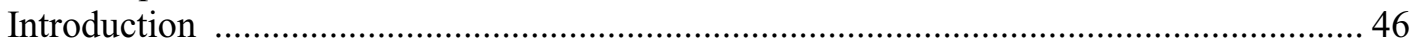

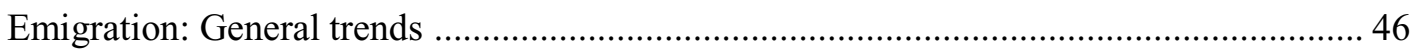

Return migration, chain migration and changes in the geography of emigration ............... 51

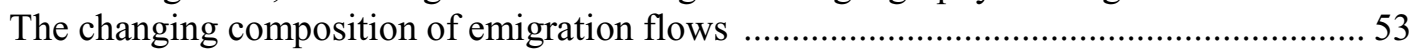

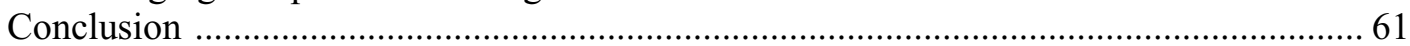

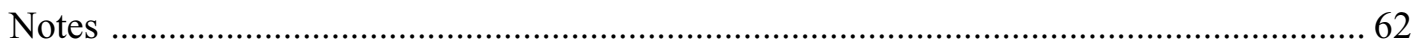

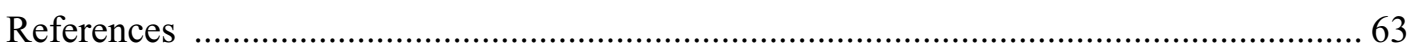

Chapter 4. Emigration from Latvia: Recent trends and economic impact ..................... 65

By Mihails Hazans

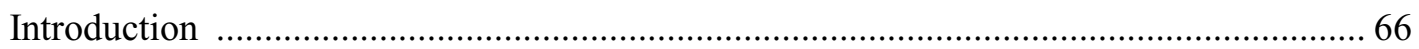

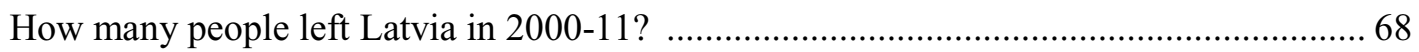

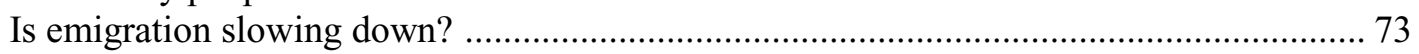

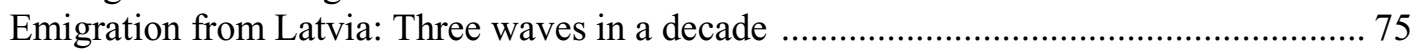

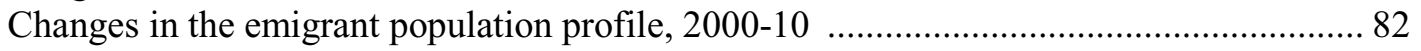

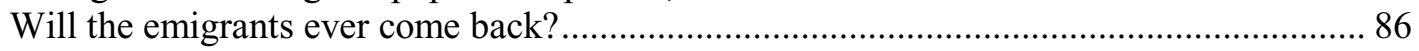

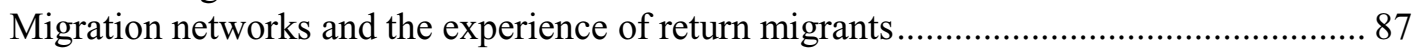

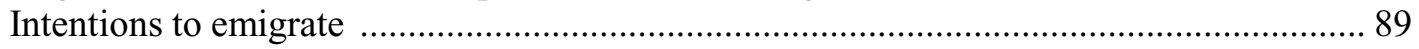




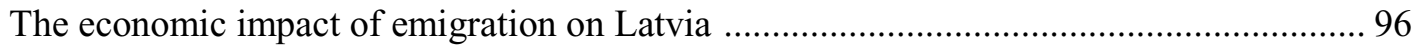

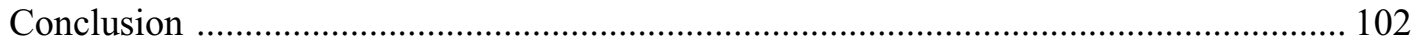

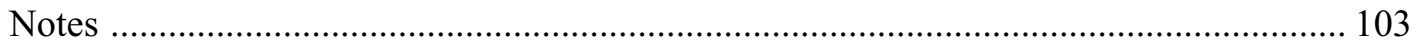

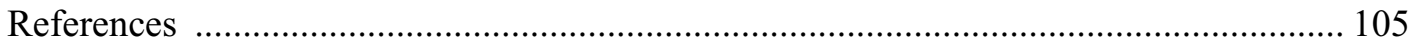

Annex 4.A1. Emigration accounting based on Latvian Population Census

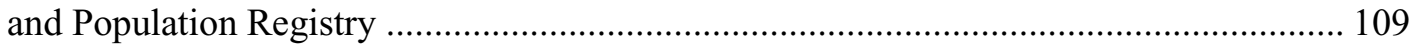

Chapter 5. Matching the skills of return migrants to labour market needs in Poland . 111 By Pawel Kaczmarczyk

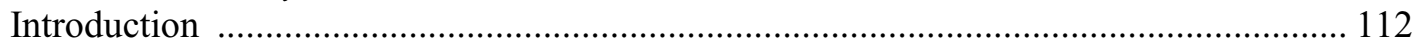

Return migration to Poland - scale and structural features .......................................... 112

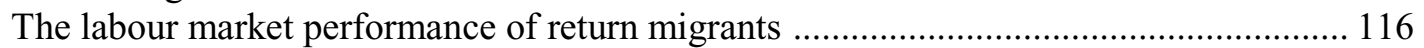

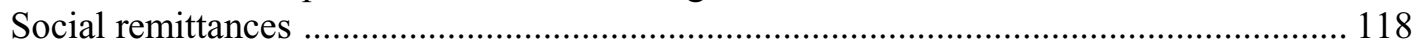

Policies and programmes targeting return migrants .............................................. 120

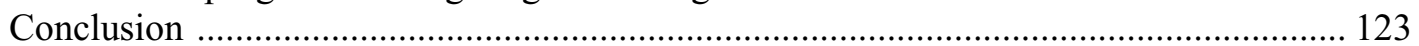

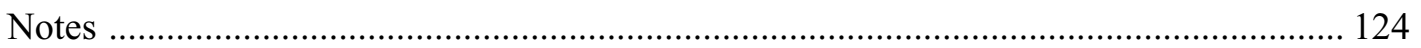

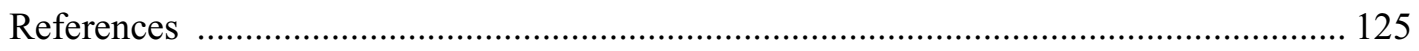

Chapter 6. Mobilising migrants skills and resources in Romania ................................. 127

By Cristina Mereuta

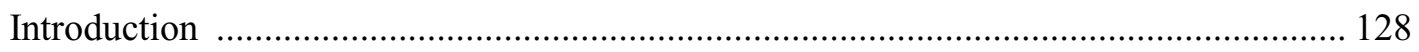

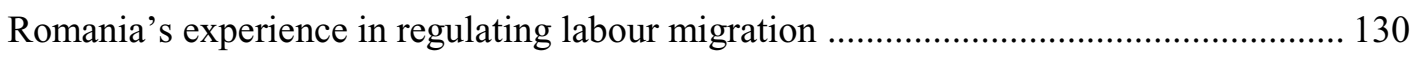

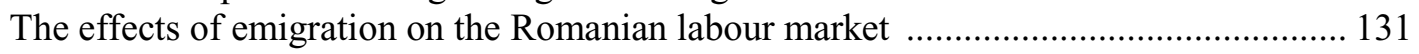

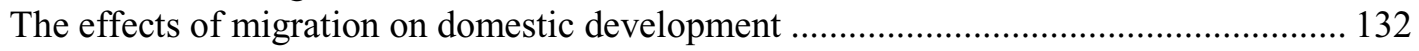

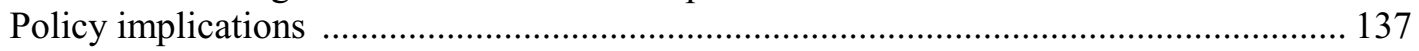

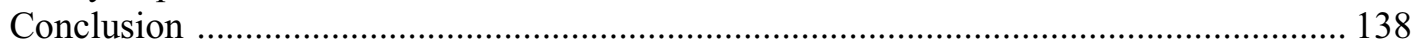

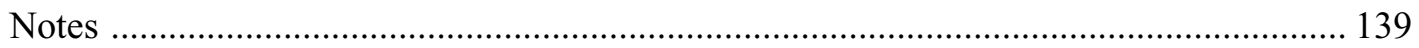

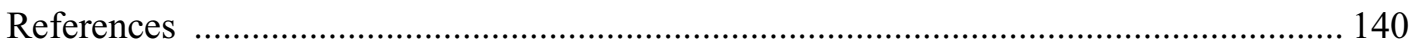

\section{Figures}

Figure 1.1. Patterns of labour migration from Central and Eastern Europe

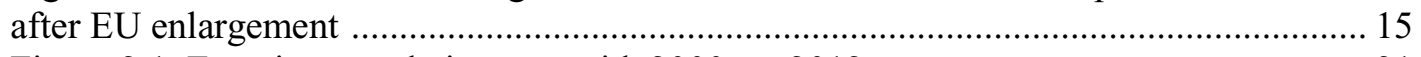

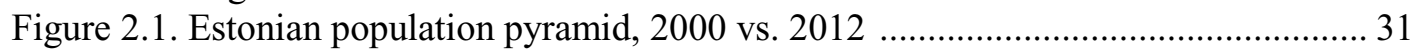

Figure 2.2. Migration to and from Estonia, 2004-11 ..................................................... 31

Figure 2.3. Immigrants to Estonia, by nationality, and the share of Estonian

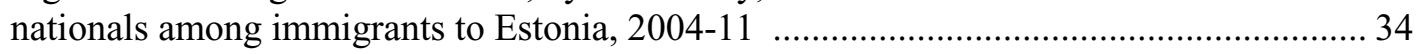

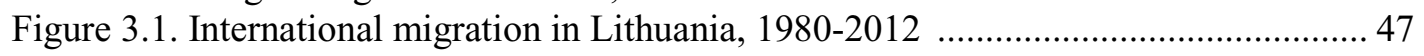

Figure 3.2. Registered and unregistered emigration from Lithuania, 1990-2012 .............. 47

Figure 3.3. Migration and economic indicators in Lithuania, 2000-10 .............................50

Figure 3.4. Total unemployment and youth unemployment, 2005-11 ............................ 50

Figure 3.5. Immigration (foreigners) and return migration (Lithuanian nationals),

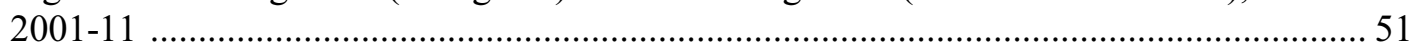

Figure 3.6. Age-sex pyramid of Lithuanian emigrants, 2007 and 2011 ............................... 53

Figure 3.7. Willingness of Lithuanians to move abroad for work, by age group ............... 56

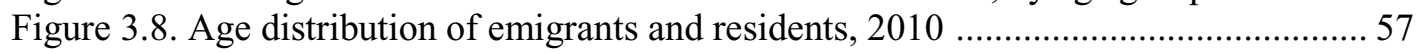

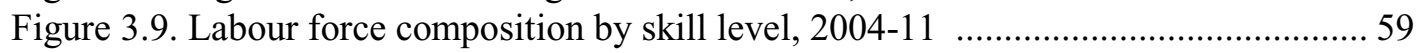

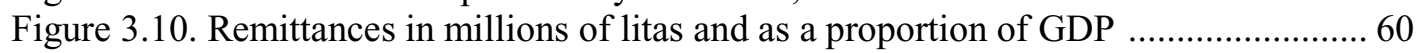

Figure 4.1. Latvian real GDP and employment during the economic crisis ........................ 66

Figure 4.2. Share of Latvia's residents aged 18-74 who perceive the processes

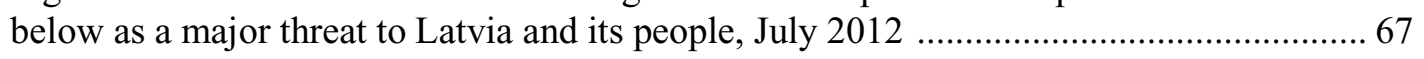


Figure 4.3. Alternative estimates of net emigration from Latvia, 2000-11 …................... 70

Figure 4.4. Net emigration of Latvian nationals by destination, 2000-11 ........................ 70

Figure 4.5. Outflows to main destination countries and registered emigration, 2009-12 ... 74

Figure 4.6. Unemployment and emigration developments in Latvia, 2002-12 ................. 79

Figure 4.7. Total monthly gross earnings from all legal jobs for employed population

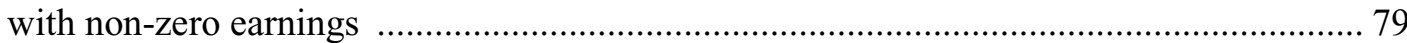

Figure 4.8. Educational attainment among emigrants from Latvia aged 22 and over by period of departure, ethnicity, citizenship and destination ......................................... 85

Figure 4.9. Emigrants' main activity abroad at the end of 2010, by educational attainment, destination and period of departure from Latvia ....

Figure 4.10. Intentions to return within six months and within five years, among emigrants from Latvia, by ethnicity and citizenship, educational attainment, destination and duration of stay abroad, 2010-11

Figure 4.11. Return migrants' assessment of the impact of their time spent abroad on various aspects of their lives

Figure 4.12. Personal net income of individuals employed in Latvia in the second half

of 2010, by their own and their family members' foreign work experience 89 Figure 4.13. Intentions to emigrate among Latvian residents aged 18-65, by educational attainment and main occupation, December 2010 to February 2011

Figure 4.14. Main reasons to reject an offer to live and work outside of Latvia

for a long time

Figure 4.15. Main reasons to accept an offer to live and work outside of Latvia

for a long time

Figure 4.16. Determined stayers and potential emigrants in population aged 18-64 f........96

Figure 4.17. Estimated share of registered unemployed among emigrants with registered labour market experience, and average last monthly amount received in benefits by emigrants before departure, 2005-11

Figure 4.18. Net emigration and job vacancy rate, 2005Q1 to 2012Q3 ........................... 98

Figure 4.19. Proportion of enterprises reporting a shortage of labour as a limiting factor, by sector, 2010 Q3 to 2013 Q2

Figure 4.20. The estimated effect of emigration on real GDP and real wages, 2001-10 .. 100 Figure 4.21. Estimated mean and percentiles of emigrants' last earnings from all jobs as a proportion of median earnings of all legally employed persons in the same month, 2005-11

Figure 4.A1.1. Population outflows from and inflows to Latvia based on Latvian data

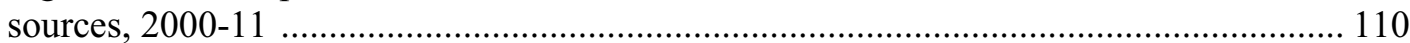

Figure 5.1. Stock of Polish migrants staying temporarily abroad, 2002-11 ..................... 113

Figure 5.2. Return migrant selectivity index by geographical region, Poland ................. 116

Figure 6.1. Romanian citizens settling permanently abroad, by nationality, 1990-2010 . 128

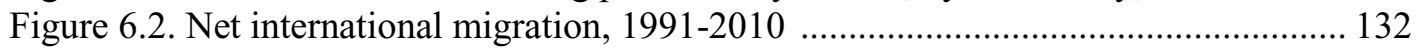

\section{Tables}

Table 1.1. Number of long-term migrants (length of stay $>1$ year) to and from the

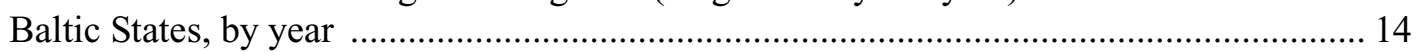

Table 1.2. Overview of the economic effects of labour migration on Romania .................. 18

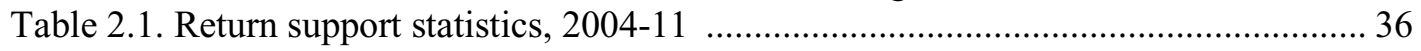

Table 3.1. Unregistered emigrants, reason for departure, 2001-07 ................................ 49

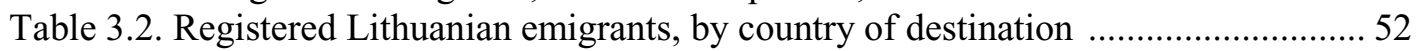

Table 3.3. Distribution of Lithuanian emigrants by age, 2007-12 …............................... 53 
Table 3.4. Parental requests for foster care for children due to parents' emigration, 2007-10

Table 3.5. Distribution of registered Lithuanian emigrants aged 18 and older, by marital status, 2001-11

Table 3.6. Distribution of registered Lithuanian migrants aged 15 and older, by previous employment, 2008-11 55

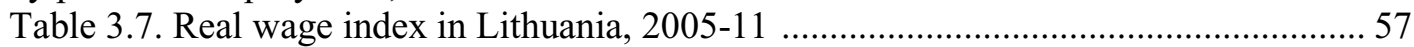

Table 3.8. Labour force, employment and unemployment in Lithuania, 2004-11 ............. 57

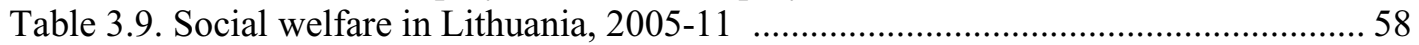

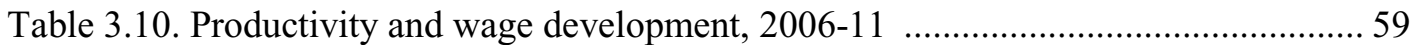

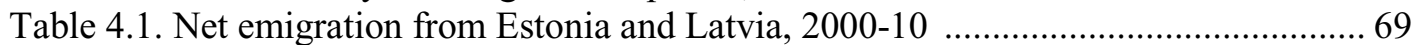

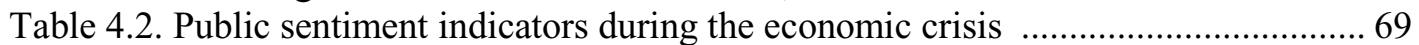

Table 4.3. Net emigration of Latvian nationals by destination, 2000-11 .......................... 71

Table 4.4. Alternative documented estimates of net emigration from Latvia, 2000-11 ..... 71

Table 4.5. Employment and unemployment rates in the working-age population,

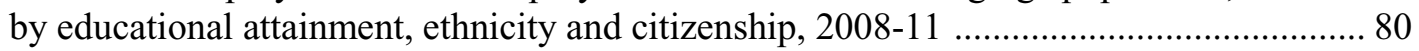

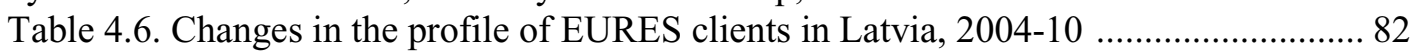

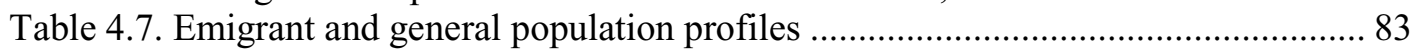

Table 4.8. Impact of demographic and occupational factors on emigration plans, population aged 18-65, December 2010-February 2011 93

Table 4.9. Unemployment or spells of economic inactivity in Latvia during the year prior to departure, among Latvian guestworkers, 2003-10 ............................................ 96

Table 5.1. Stock of Polish migrants residing temporarily abroad, 2002-11 .................... 113

Table 5.2. Selected characteristics of emigrants and return migrants .............................. 115

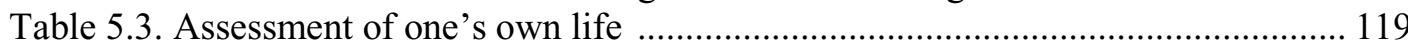

Table 5.4. Assessment of socio-economic reforms started in 1989 .................................. 119

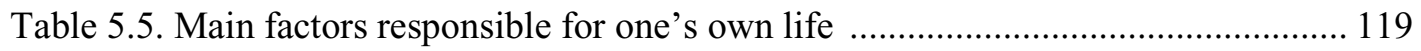

Table 5.6. Programmes/initiatives targeting potential Polish return migrants .................. 120

Table 6.1. Persons left abroad (under and over 12 months), by country of destination ... 130 


\section{Acronyms and abbreviations}

\begin{tabular}{|c|c|}
\hline AFFORD & African Foundation for Development \\
\hline CEE & Central and Eastern European countries \\
\hline CIMO & Centre for International Mobility \\
\hline $\mathrm{CSO}$ & Central Statistical Office (Poland) \\
\hline $\mathrm{DnB}$ & NORD Latvian Barometer \\
\hline EALE & European Association of Labour Economics \\
\hline EEA & European Economic Area \\
\hline EURES & European Employment Services \\
\hline FEDROM & Federation of Romanian Associations in Spain \\
\hline GDP & Gross domestic product \\
\hline GlobalScot & Scottish Enterprise manages an International Business Network \\
\hline $\mathrm{IOM}$ & International Organisation for Migration \\
\hline ISCO & International Standard Classification of Occupation \\
\hline LFS & Labour Force Survey \\
\hline LTL & Lithuanian lita \\
\hline LVL & Latvian lat \\
\hline NIESR & National Institute of Economic and Social Research (United Kingdom) \\
\hline NIPCM & National Identity: Place, Capability, Migration Survey (Latvia) \\
\hline NORFACE & New Opportunities for Research Funding Co-operation Agency in Europe \\
\hline PES & EU Public Employment Services \\
\hline SEA & State Employment Agency (Latvia) \\
\hline SKDS & Marketing and Public Opinion Research Centre (Latvia) \\
\hline SSIA & State Social Insurance Agency (Latvia) \\
\hline SSN & Social security number \\
\hline
\end{tabular}





\section{Executive summary}

The three Baltic countries, Estonia, Latvia and Lithuania, have seen constant net emigration over the past decade. Net emigration over the 2000s was equivalent to almost $6 \%$ of the population in Estonia, 9\% in Latvia and 13\% in Lithuania. While this served as a safety valve in a time of poor employment opportunities and led to high levels of remittances, the longer term implications appear less positive: smaller working-age population, loss of educated youth, and skills shortages. A substantial diaspora has formed abroad, and these countries are starting to develop policies for interacting with these recent emigrants, many of whom are not expected to return definitively, to allay the economic and social impact of their departure. Other European countries are facing similar circumstances, especially Poland and Romania; in Romania, population fell by $7 \%$ over the decade largely due to emigration. The negative demographic situation in these countries - low fertility and ageing populations - exacerbates the impact of emigration. The experience of OECD countries with longstanding diasporas points the way to some innovative responses, if not to large-scale return.

\section{Key findings}

Emigration in these countries rose following their accession to the European Union in 2004 and again with the economic crisis which began in 2008. Outflows peaked in 2010 in the Baltic countries and have not yet fallen back to their pre-crisis levels. Poland, in contrast to the other countries, experienced return inflows in 2008-10.

The main countries of destination were the United Kingdom and Ireland for Poles, Latvians and Lithuanians. More recently Norway has emerged as a destination. Finland was the destination for Estonians; Italy and Spain for Romanians. Most went for employment. Germany has attracted more qualified migrants from these countries.

Emigration from the Baltic countries is increasingly comprised of youth, concentrated between 20 and 35 years old, of highly educated people and of entire families. Estonia is an exception as its emigrants are largely less educated single men. For students, work abroad is now a common post-graduation plan. In Baltic countries, emigrants are increasingly looking for permanent skilled employment abroad. It was not only the unemployed who went abroad to work: many emigrants were employed before they left - three-quarters in the case of Latvia. A large share were employed abroad in jobs for which they were overqualified - two-thirds of Polish migrants,

The economic impact of emigration has been notable and mostly negative, especially when seen in a long-term perspective. Remittances make a significant contribution - almost $5 \%$ of GDP in Lithuania, for example, and 3\% in Romania - and emigration was an important safety valve for the slack labour market in times of crisis. Skills shortages are starting to be felt in these countries, however, and there is evidence of distortion of the wage structure for high and low skilled workers due to disproportionate emigration by the latter. 
Those who return tend to be the less educated. Return migrants are more likely to be unemployed, although are working enjoy higher wages associated with their foreign experience. There is evidence that return migrants are more productive in Romania, and have higher rates of entrepreneurship in Poland.

Return policies have met with limited success, especially where underlying economic conditions are not favourable, or where the salary differential abroad is substantial. Job fairs aimed at emigrants from Romania did not lead to many returns. Polish programmes to bring back emigrants were stymied by insufficient planning, by negative economic conditions and by the requirement not to favour returnees over non-migrants.

Diaspora policies are developing. Diaspora bonds, used in Israel and India, for example, can attract lower cost capital from emigrants and give them a means to contribute to economic development when they no longer have family to which to send remittances. Political representation, as provided by Portugal and Mexico, is another means of ensuring that emigrants stay connected. Diaspora services such as those run by Ireland and Mexico advocate for communities abroad, defending their interests. Language and culture support are traditional activities that allow for stronger ties with the origin country. Symbolic initiatives such as prizes and recognition, or exclusive clubs, can support business networks with positive commercial return.

\section{Conclusion}

Emigration continues to affect the labour markets of the Baltic countries and hinders the growth in the working-age population. Emigration appears to have become a structural feature in these countries and will continue, albeit likely at a lower level than in the crisis years, exacerbating emerging skills shortages.

Most recent migrants are unlikely to return soon. Targeted return policies providing information to emigrants about changing economic and social conditions in the origin country, and allowing employers to reach out to diasporas, may help promote some returns, but good opportunities and salary conditions remain determinant.

Networks can foster links with the origin country even if no return occurs. Smaller scale fellowships and youth mobility initiatives may be feasible. Economic and trade ties can be built on diaspora presence abroad, with more symbolic and emotional contribution than financial investment.

Policies to engage diasporas play a key role in ensuring that emigrants maintain ties with the origin country. Diaspora engagement is not cost-free, as it requires infrastructure, services and better knowledge of the characteristics and intentions of diaspora communities. 


\title{
Chapter 1
}

\section{Emigration from the Baltic States: Economic impact and policy implications}

\author{
Godfried Engbersen \\ Erasmus University Rotterdam \\ and \\ Joost Jansen \\ Erasmus University Rotterdam
}

This chapter analyses the extent and contexts of Baltic migration flows, and sketches a profile of Baltic emigrant populations. The potential economic impact of high negative net migration on these countries is addressed, along with relevant findings from Poland and Romania. Policy strategies and initiatives taken by Baltic States and other emigration countries are presented and discussed. The chapter concludes by identifying areas requiring further research in matters pertaining to rising emigration, its economic impact and the conditions under which diaspora policies contribute to the economic development of home countries. 


\section{Introduction}

Emigration from the Baltic States (Estonia, Latvia and Lithuania) has rapidly increased over the past decades, a phenomenon that has accelerated dramatically since the three countries joined the European Union in 2004. This outflow of population is reflected in very high negative net migration rates and results in considerable depopulation. The governments of the states in question consider this development to be a serious and threatening problem. The Latvian Government, together with the OECD, therefore organised an international conference, held in Riga on December 17, 2012, to discuss the rapidly increasing emigration from the Baltics, its possible economic impact and initiatives to guarantee a healthy socio-economic future for Estonia, Latvia and Lithuania. This chapter summarises the main findings from the papers presented in this volume.

\section{Migration flows from the Baltics: The extent of migration and migrant population profiles}

On September 6, 1991 Estonia, Latvia and Lithuania regained their independence after decades of Soviet occupation. As noted by Hazans (cf. Chapter 4), this historical event led to major changes in population composition and increasing emigration, which resulted in considerable depopulation and negative annual net migration rates in the three Baltic States.

Steady economic growth in the three Baltic States at the turn of the $21^{\text {st }}$ century caused emigration to decline. Moreover, the costs of emigration were relatively high due to the fact that residence and work permits were required by law. In 2004, however, when the Baltic States became members of the European Union and free movement of labour gradually became possible, net migration again plummeted. In several waves of emigration since the beginning of the $21^{\text {st }}$ century, Latvia, for example, lost $9.1 \%$ of its population (including almost $14 \%$ of its labour force) (cf. Chapter 4 ).

Very rapid economic growth following EU accession caused emigration rates to drop slightly. Unfortunately, however, since 2008 emigration rates rose yet again due to the global economic crisis. Lithuania, for example, had the highest negative net migration in the European Union in 2008 (OECD, 2010), and in Latvia negative net migration almost tripled between 2007 and 2008. Table 1.1 presents a more detailed overview of inflows and outflows of population in the three Baltic States. The immigration and emigration data in Table 1.1., from Eurostat, differs from national data reported elsewhere in this volume (from Statistics Estonia and Statistics Latvia, e.g.), raising the question of crosscountry comparability.

Table 1.1. Number of long-term migrants (length of stay $>1$ year) to and from the Baltic States, by year

\begin{tabular}{lrrrrrrrrrrrr}
\hline & $\mathbf{2 0 0 0}$ & $\mathbf{2 0 0 1}$ & $\mathbf{2 0 0 2}$ & $\mathbf{2 0 0 3}$ & $\mathbf{2 0 0 4}$ & $\mathbf{2 0 0 5}$ & $\mathbf{2 0 0 6}$ & $\mathbf{2 0 0 7}$ & $\mathbf{2 0 0 8}$ & $\mathbf{2 0 0 9}$ & $\mathbf{2 0 1 0}$ & $\mathbf{2 0 1 1}$ \\
\hline Estonia & & & & & & & & & & & & \\
Emigrants & 1784 & 2175 & 2038 & 3073 & 2927 & 4610 & 5527 & 4384 & 4406 & 4658 & 5294 & 6214 \\
Immigrants & 35 & 241 & 575 & 967 & 1097 & 1436 & 2234 & 3741 & 3671 & 3884 & 2810 & 3709 \\
Net migration & -1749 & -1934 & -1463 & -2106 & -1830 & -3174 & -3293 & -643 & -735 & -774 & -2484 & -2505 \\
\hline Latvia & & & & & & & & & & & & \\
Emigrants & 7131 & 6602 & 3262 & 2210 & 2744 & 2450 & 5252 & 4183 & 6007 & 7388 & 10702 & 30380 \\
Immigrants & 1627 & 1443 & 1428 & 1364 & 1665 & 1886 & 2801 & 3541 & 3465 & 2688 & 2364 & 7253 \\
Net migration & -5504 & -5159 & -1834 & -846 & -1079 & -564 & -2451 & -642 & -2542 & -4700 & -8338 & -23127 \\
\hline Lithuania & & & & & & & & & & & & \\
Emigrants & 2616 & 7253 & 7086 & 11032 & 15165 & 15571 & 12602 & 13853 & 17015 & 21970 & 83157 & 53863 \\
Immigrants & 1510 & 4694 & 5110 & 4728 & 5553 & 6789 & 7745 & 8609 & 9297 & 6487 & 5213 & 15685 \\
Net migration & -1106 & -2559 & -1976 & -6304 & -9612 & -8782 & -4857 & -5244 & -7718 & -15483 & -77944 & -38178 \\
\hline
\end{tabular}

Source: Eurostat (2012), data accessed from datasets migr_emilctz and migr_immlctz. 
The desire to leave the Baltic countries is strongly related to economic decline and rising unemployment. OECD data (2012) reveal that young men of working age have a higher propensity to emigrate in the presence of unemployment and cutbacks on social welfare, both conditions which are found in the Baltic countries. Destinations vary according to economic opportunities, legal barriers and geographic and linguistic proximity. Finland is the most popular country of destination among emigrants from Estonia. Latvian and Lithuanian emigrants mainly go to the United Kingdom, the United States, Ireland, Norway and Germany (cf. Chapter 3).

The profile of the labour migrant population is crucial to the understanding of the economic impact of emigration on the country of origin. Four ideal-typical patterns of contemporary labour migration within the European Union (especially from Central and Eastern Europe to Western Europe) can be identified (Eade et al., 2007; Düvell and Vogel, 2006; Grabowska-Lusinska and Okolski, 2009; Engbersen et al., 2013). These four patterns are derived from two dimensions of migration and integration, i.e., i) the degree of labour migrants' attachment to their country of origin; and ii) the degree of their attachment to their destination country. These attachments can be "weak" or "strong" (see Figure 1.1). The four patterns can also be consecutive (Engbersen et al., 2013), so that temporary migration can lead to transnational and ultimately to settlement migration, but this process does not necessarily apply to every individual labour migrant. Contemporary labour migration is not only diverse, but also dynamic and changeable (Friberg, 2012).

Figure 1.1. Patterns of labour migration from Central and Eastern Europe after EU enlargement

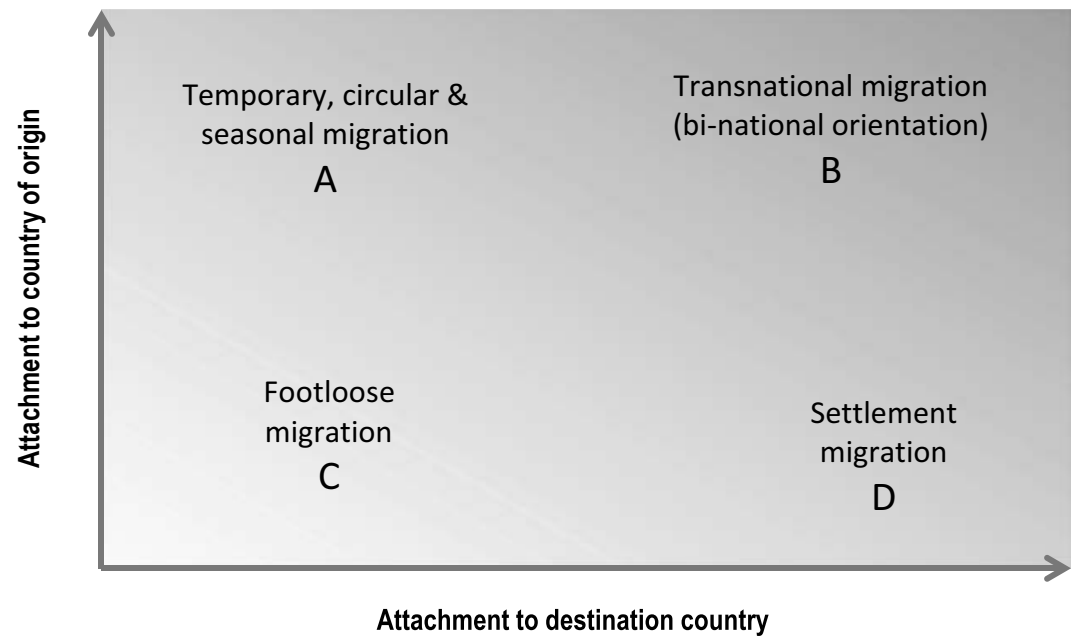

Source: Engbersen, G. et al. (2013), "On the Differentiated Attachments of Migrants from Central and Eastern Europe. A Typology of Labour Migration", Journal of Ethnic and Migration Studies, Vol. 39, No. 6, pp.959-981, http://dx.doi.org/10.1080/1369183X.2013.765663.

Migration patterns from the Baltic States also come in various types. The profile of Latvian emigrants, for instance, has changed significantly in recent years (cf. Chapter 4). The percentage of Latvian emigrants with higher education has been steadily increasing ( $24 \%$ are university graduates), and they are more oriented towards long-term or even permanent migration together with their families (only $23 \%$ plan to return to Latvia within five years). Students have the highest propensity to emigrate among Latvians. This pattern can therefore be characterised as either transnational or settlement migration. 
Latvian emigrants are decreasingly tied to their country of origin and increasingly tied to their country of destination.

The average Estonian emigrant is a male blue-collar worker aged 15-34 who moves to Finland to work in the construction sector (cf. Chapter 4; Anniste, 2012). The profile best matches that of a circular migrant: a labour migrant who works abroad on a temporary basis because of unfavourable labour circumstances in his country of origin. According to Kaska (cf. Chapter 2), the probability of return migration is high during the first five years after arrival, and decreases steadily thereafter.

Lithuanian emigrants are mainly people of working age. In 2011, young people aged 20-34 years formed more than half (55.4\%) of all emigrants (compared with $46.6 \%$ in 2008) (cf. Chapter 3). According to the International Organisation for Migration (IOM) (2011), emigration from Lithuania predominantly involves educated individuals, of which over $50 \%$ completed at least upper secondary vocational education. Also, the emigration of families, whose probability of returning is lower, is increasingly frequent in Lithuania. The pattern of Lithuanian emigration therefore resembles the Latvian pattern, in that emigrants tend to be oriented towards a long-term or even permanent stay abroad. Different migration patterns result in different economic outcomes and thus require differentiated policy approaches. Long-term migrants have relatively weak ties with their countries of origin compared to, circular migrants, for example. Policies targeting permanent emigrants may aim at maintaining (cultural) links with the country of origin or setting up business networks with successful entrepreneurs working abroad, while programmes targeting temporary emigrants may provide them with specific labour market information and consultation on their return.

\section{The economic impact of emigration on the Baltic States, Poland and Romania}

This section draws on current research on the possible impact of emigration on Baltic economies, including documents and discussion at the international conference on "The Economic Impact of Emigration in Latvia and the Other Baltic Countries: Challenges and Policy Implications" (co-organised by the Latvian Ministry of Foreign Affairs and the OECD in Riga on 17 December 2012).

The case of Latvian emigration is discussed by Hazans (cf. Chapter 4). Emigration from Latvia is increasing rapidly and is considered by Latvian policy makers to be an urgent problem. As in the case of Estonia and Lithuania, Latvian emigration is closely related to fluctuations in economic conditions and to external factors such as EU accession. The Latvian economy grew steadily during the years before the economic crisis, which caused emigration to decline. In the years following the outbreak of the economic crisis, the outflow of population rapidly increased. Economic decline, rising unemployment and increasing social insecurity are common reasons for Latvian young adults (mostly students and those with post-secondary education) to leave their country.

An important finding concerns emigrants' intended length of stay abroad (cf. Chapter 4): a recent survey shows that an increasing number of Latvian emigrants are oriented towards long-term or even permanent emigration. This is likely to result in the weakening of ties with their country of origin, and to carry implications for diaspora policies should Baltic governments wish to mobilise financial resources and human capital abroad. Policy makers must take into account that the longer emigrants intend to stay abroad, the less probable their return, and the less inclined they would be to transfer skills and to invest in Latvia. This calls for the development of appropriate policy 
programmes, such as those aimed at maintaining cultural links. Kaska (cf. Chapter 2) discusses recent trends and the economic impact of emigration from Estonia. Here too, as in other Baltic States, emigration occurred in waves: in 1991, when Estonia regained its independence; in 2004, when it joined the European Union; and after 2008, when the economic crisis hit the country. Studies show that currently, Estonian emigrants tend to be young male blue-collar workers. Finland is the most popular destination among Estonian emigrants.

Due to the lack of adequate data regarding the extent and patterns of Estonian emigration, it is unclear whether such emigration can directly affect the composition of Estonia's labour market and reduce unemployment. Data is insufficient also with respect to the composition, or profile, of the population of emigrants (e.g., in terms of their occupations and intended length of stay abroad). Furthermore, insights are needed into the potential benefits of emigration in terms of remittances and human capital flowing back into the country of origin. Estonia has yet to determine how to channel its significant flow of remittances to make the necessary investments for the benefit of the country's economic development.

Sipavičienè and Stankūnienè (cf. Chapter 3) elaborate on the socio-economic impact of emigration from Lithuania. The country tops the list of European countries with high negative net migration. Emigration trends seem to be correlated with economic developments. As in the case of Estonia, most emigrants from Lithuania are young workers. A worsening economic climate leads (almost directly) to an increase in emigration. Vice versa, the socio-economic effects of such emigration on Lithuania remains to be studied.

The large-scale emigration has certainly had a dampening effect on Lithuanian unemployment: all other things being equal, unemployment in Lithuania would have been higher had it not been for such large numbers of emigrants (cf. Chapter 3). An analysis of the association between emigration and labour market structure in Lithuania should, however, take other factors into account as well. Demographic factors, for instance, such as an exceptionally large cohort of young workers entering the labour market, could obfuscate the influence of emigration.

As for migrants' remittances, Sipavičienè and Stankūnienè (cf. Chapter 3) note that these are important to individuals and families in Lithuania, inasmuch as they cushion the consequences of the economic crisis and compensate for financial problems due to drastically reduced incomes. The impact of remittance flows on Lithuanian economic development and investments, however, has thus far not been evaluated. There is an urgent need for a systematic evaluation based on realistic data (Pawson and Tilly, 2008).

Mereuta (2012) discusses the case of Romanian emigration, analysing how emigration can influence economic development. Romania is Europe's largest source of migrants. Most Romanian long-term migrants live in Italy or in Spain. According to this paper, Romanian emigration has had multiple positive effects on its domestic economic situation: lower unemployment rates, for example, and decreased pressure on social protection budgets. Nevertheless, there have also been negative effects, such as labour shortages, skill gaps and even depopulated areas. Table 1.2 provides a synopsis of potential economic effects on sending countries. 
Table 1.2. Overview of the economic effects of labour migration on Romania

\begin{tabular}{l|l}
\hline \multicolumn{1}{c|}{ Positive effects } & \multicolumn{1}{c}{ Negative effects } \\
\hline Lower unemployment rates & $\begin{array}{l}\text { Negative demographic trends (ageing, lack of } \\
\text { territorial cohesion) } \\
\text { Unbalanced distribution of the available } \\
\text { werkforce by sector and geographical area }\end{array}$ \\
$\begin{array}{l}\text { budgets } \\
\text { Remittances support the improvement of } \\
\text { living standards }\end{array}$ & $\begin{array}{l}\text { Business losses due to wage pressure } \\
\text { (especially prior to 2008) and reduced } \\
\text { production } \\
\text { Brain drain (loss of investment in education } \\
\text { Workers abroad facilitate skill transfer and } \\
\text { growth }\end{array}$ \\
$\begin{array}{l}\text { and training, lower competitiveness) } \\
\text { Athreat to the sustainability of social protection } \\
\text { systems (pension, medical care) }\end{array}$ \\
\hline
\end{tabular}

Source: Mereuta, C. (2012), "Mobilising Migrant's Skills and Recourses - The Case of Romania”, Paper prepared for the international conference on "The Economic Impact of Emigration in Latvia and the Other Baltic Countries: Challenges and Policy Implications", co-organised by the Latvian Ministry of Foreign Affairs and the OECD, 17 December 2012, Riga.

Poor data on emigration patterns in Romania have hindered research into the actual impact of emigration from Romania on its economy. For instance, net migration has decreased over the past few years, yet no convincing explanations are given for this development. Hence, the putative positive effects of emigration on the Romanian economy (e.g. lower unemployment, decreased pressure on social protection budgets) may be the outcome of other processes. Precise data regarding the Romanian emigration pattern and its causes is needed for an in-depth analysis of its economic impact.

Kaczmarczyk (cf. Chapter 5) considers the case of Polish returnees and their labour market performance after returning to their country of origin. Poland, like Romania and the Baltic States, can be characterised as a country of emigration. Here too, emigration rocketed when Poland acceded to the European Union in 2004. Every year, large numbers of young emigrants leave the country in search of a job abroad, especially in Ireland, the United Kingdom, Sweden, Norway, the Netherlands. Since Polish migration is often "fluid" (temporary), however, there is also a significant flow of reverse migrants (Engbersen, 2012). The economic crisis is expected to magnify the scale of return migration.

Poland encourages migrants to return to their home country, so that their financial capital and foreign work experience can be mobilised for the benefit of national socioeconomic development. Kaczmarczyk (cf. Chapter 5) reveals, however, that return migrants were more exposed than non-migrants to the risk of unemployment. He shows that a migration background influences labour market performance in a negative way, and thus almost no skill transfer takes place.

In the Polish case, the presumed advantages of luring return migrants back home in order to mobilise their human capital turn out to be doubtful (cf. Chapter 5). The absence of skill transfer is mainly due to the fact that the majority of Polish emigrants work abroad in jobs that do not match their qualifications. The case of Polish emigration questions the common belief that there is a positive association between emigration on one hand and the transfer of human capital on the other. 


\section{In pursuit of successful diaspora policies: Baltic initiatives and experiences from other sending countries}

\section{The ambiguous potential of remittances}

Migration economics teaches that emigration can in time result in economic and social development in sending countries, partly thanks to remittances sent back by emigrants. Remittances have the potential to increase overall income and maybe even improve living standards (e.g. better education, health care) (De Haas, 2007). This economic and social development may eventually lead to declining population outflows.

A key question is whether or not emigration from the Baltic States leads to increasing remittance flows and thus contributes to economic development and social improvement. All three Baltic States actively try to strengthen ties with their emigrants by developing various policies, in order to "to mobilise the financial resources and human capital of the diaspora" (OECD, 2012). Baltic governments try to maximise the potential positive effects of emigration. According to the OECD (2012), remittances have indeed grown into a substantial source of gross domestic income over the last decade. In Lithuania for example, remittance flows now account for over USD 3 billions (which is almost 5\%) of Lithuania's gross domestic product (GDP). In Estonia and Latvia remittance flows have also grown substantially over the past ten years, and currently amount to $2 \%$ and $3 \%$ of GDP, respectively. In times of economic crisis, remittances have the potential to partly compensate for the loss of GDP, as in the case of Latvia (cf. Chapter 4).The magnitude of these capital flows as well as their economic and social impact, remain ambiguous, however. The aggregate numbers do not tell us where exactly the remittances are flowing to, how they are invested or how they contribute to national development. De Haas (2007) states that: "Notwithstanding their often considerable blessings for individuals, households and communities, migration and remittances are no panacea for solving more structural development problems." Consequently, emigration from, and remittances to Baltic States are both strategies to overcome unfavourable economic conditions in the migrants' country of origin. No doubt, remittances have the potential to grant individuals and households a stable income in times of economic misery. The challenge for the governments of the Baltic States is to channel remittances and mobilise the financial resources of the diaspora for the sake of national development.

So-called "diaspora bonds" are one useful response (Handjiski, 2012). The issuance of these bonds enables countries to tap into the savings of emigrants as a stable and relatively cheap source of finance for structural investments. Baltic States may be able to channel remittances and savings and mobilise the financial resources of the diaspora. The experiences of India and Israel, countries which have raised USD 35-40 billion using these bonds (Ketkar and Ratha, 2007), may be useful.

As long as the political and economic conditions in sending countries remain unfavourable, policies to channel remittances will be difficult to develop. Remittances are in fact a strategy to overcome these unfavourable conditions, which is why individuals tend to support their own family members, rather than invest. The chapters which follow in this publication underline that until governments succeed in improving social and economic conditions, remittances will most likely not be allocated to investment in the Baltic States. 


\section{The development of successful diaspora policies}

The chapters in this volume emphasize that there is much to be gained from emigration, especially by mobilising the skills and human capital of return emigrants, and by increasing the economic impact of remittances. For the development of successful diaspora policies, Estonia, Latvia and Lithuania can build on a body of existing academic research and international experience. The International Organization for Migration (IOM, 2006), for instance, has found that policy success in engaging with diasporas depends on the ability to deal with their complex and heterogeneous nature. The IOM also developed a diaspora policy roadmap summarising the key stages of diaspora policy making.

The issue of migration and development, and of successful diaspora policies has regained substantial interest in academia, governments and international agencies over the past few years (De Haas, 2006). Initial pessimism concerning the effects of emigration (e.g. "brain drain") gave way to a widespread optimistic belief regarding the development and poverty-reducing potential of remittances (De Haas, 2006; Adams and Page, 2005; World Bank, 2006). A tremendous increase in remittance flows to emigration countries has strengthened this belief among policy makers (Carling, 2008a).

Despite this optimism, the real economic impact of large-scale emigration on home countries is complex and rather heterogeneous, varying across different emigration patterns and diaspora policies implemented. The fundamental question, therefore, should be, how do different migration policy environments affect the association between emigration and development outcomes (De Haas, 2006, p. 13). In addition, the IOM (2006) points to an urgent need to clearly define the role of governmental diaspora policies in mobilising diasporas to further economic development in home countries.

Because of the substantial increase in remittance flows, virtually all diaspora policy makers aim to enhance the development impact of this financial resource. To do so, they can, for example, aim to increase the volume of current remittance flows, or choose to stimulate the direct investment of remittances (which, as previously noted, is very difficult) (Carling, 2008a). Underlying these different policy strategies, however, there are three central issues that can either make or break diaspora policies on remittances, and thus need to be thought through in advance.

Firstly, policies that explicitly target and favour emigrants should be avoided, as they are liable to create tensions between migrants and non-migrants and thus undermine the development benefits of migration. Secondly, policy makers need to consider the question of remittance ownership. The relationship between senders remitting money and receivers in home countries is often tense and complex, as the financial transaction creates an obligation for receivers, and senders do not have accurate information on how the money is spent. Policies thus have to respect the private nature of remittances. Lastly, there's the issue of the long-term sustainability of remittance flows. As migration gradually becomes permanent, remittance flows tend to decrease due to looser attachments to the country of origin. Therefore, precise information on migration patterns and on the determinants of migrant remittances is crucial for the development of successful remittance policies (Carling, 2008a and 2008b).

Crucial to the success of diaspora policies is the ability to foster co-operation between local (including government) initiatives and different diaspora groups, and to build on already existing initiatives (IOM, 2006; De Haas, 2006; Newland and Patrick, 2004). It is important to acknowledge that fruitful diaspora and development projects often come 
from within diasporas and that state-led initiatives should co-operate with such existing projects. Exemplars of successful initiatives originating in the diaspora are spontaneous movements and associations. For instance, the French-Moroccan Association Migrations et Développement is a grassroots organisation that successfully committed itself to release the development potential of Moroccan emigration in the country of origin. It has implemented numerous effective development projects in over 400 Moroccan villages and is now consulted by the Moroccan Government on future development projects (De Haas, 2006). The African Foundation for Development (AFFORD, founded in the United Kingdom) provides another example of an influential non-governmental organisation that successfully seeks to engage the African diaspora in initiatives to promote economic development in Africa through various activities, such as negotiating with international financial companies to provide a cheap remittance transfer services to migrants (ibid.).

\section{Successful diaspora policies around the world}

The safest and most effective approach to develop diaspora policies is thus to build on and support such successful existing initiatives (cf. also Newland and Patrick, 2004). Historically, countries like Israel, Mexico, Scotland and Ireland have large populations of emigrants living abroad, and a vast experience in the development of diaspora policies, from which much can be learned.

The Irish Department of Foreign Affairs and Trade has initiated the so-called "Irish Abroad Unit" (Gardner, 2012). This is a unit within the Department that co-ordinates the provision of financial support to voluntary and Irish community organisations engaged in the delivery of services to (vulnerable) Irish communities abroad (www.dfa.ie). Its mission is to maintain and strengthen links between Ireland and existing Irish communities overseas. By supporting these existing Irish communities abroad, the Department fully acknowledges its role as facilitator rather than sole-implementer of diaspora engagement.

The Mexican diaspora is one of the largest diasporas worldwide, with over 12 million native Mexicans living abroad. It is also the most concentrated diaspora: approximately 95\% of the Mexicans abroad live in the United States (Diaz de Leon, 2012). Since many Mexican emigrants have no intention to return to Mexico, the Institute for Mexicans Abroad (a decentralised unit of the Mexican Ministry of Foreign Affairs) aims not only to develop links between migrants and their country of origin, but also to promote the integration and empowerment of migrants in their country of destination and increase their quality of life (e.g. in terms of education and health care). Through a decentralised, local and communal approach, often in close co-operation with US public institutions, Mexican consulates carry out effective policies to improve the living conditions of migrants and their families, and hence strengthen links between Mexico and its diaspora.

Birthright Israel is a private organisation (funded by the Government of Israel, Jewish communities around the world and committed philanthropists) that sponsors trips to Israel for Jewish young adults. The organisation aims to "change the course of Jewish history and ensure the continuity of the Jewish people by strengthening Jewish identity, Jewish communities, and solidarity with Israel via an educational trip to Israel for Jewish young adults around the world" (www.birthrightisrael.com). More than 400000 participants have taken the trip to Israel (50 000 annually), of whom over $30 \%$ went back to Israel within a five-year period. Moreover, participants are $46 \%$ more likely than their counterparts to feel very much connected to Israel (Schnytzer, 2012; Saxe et al., 2011). 
With over 4 million citizens living abroad, Portugal tries to maintain links with its emigrant population and engage them through active political participation. Portuguese citizens living abroad have the right to vote for the President of the Portuguese Republic, as well as for the Portuguese Parliament, where four seats are reserved for their representatives (Da Fonseca, 2012). To participate in these elections, Portuguese citizens must be registered with the Portuguese consulate and vote in person. In this way, Portugal encourages its diaspora members to remain closely attached to their country of origin.

Working in close collaboration with the Scottish Government and other private partners, Scottish Enterprise manages an International Business Network named "GlobalScot" with the objective of "harnessing the drive, ambition and talent of high profile, successful Scots (and those with an affinity with Scotland) who are committed to advancing Scotland's economic success" (Reid, 2012). These may not necessarily be Scottish, but are nominated on the basis of affinity or mutual interest. Since its launch in 2001, the network has attracted over 650 senior level members throughout the world. Members of the GlobalScot network are based in markets that are important for Scottish companies to access, and have become important sources of investment in the Scottish economy. Finland has also developed specific diaspora programmes, such as the Centre for International Mobility (CIMO), established in 1991 (Vehkanen, 2012). This organisation, operating under the Finnish ministry of Education and Culture, aims to promote the teaching of Finnish language and culture. Whereas the bulk of funds for the CIMO comes from the Finnish Government, about $70 \%$ of the annual expenditure is drawn from external sources (e.g. the European Commission and the Nordic Council of Ministers, www.cimo.fi). Since its launch, about 25000 people took part in CIMO's programmes at more than 100 universities in over 30 countries around the world.

Estonia, Latvia and Lithuania have also started to develop policies aiming to maximise the positive impact of their respective diasporas. The Estonian Government encourages emigrants to return through the so-called "return support" (cf. Chapter 2). Estonia is trying to lure back long-time emigrants (who have not lived in Estonia for at least ten years) by paying them up to EUR 2000 per adult, but it is unclear how return support can contribute to maximising the positive economic effects of emigration, considering the Estonian migration pattern. An additional Estonian project targeting emigrants is the portal "Talents back home!", providing emigrants with strategic information about job opportunities in the country. The portal was developed by the Estonia Chamber of Commerce and Industry (Gornischeff, 2012).The co-ordination and implementation of Lithuanian diaspora policies fall within the responsibilities of the Lithuanian Ministry of Foreign Affairs. The objective of such policies is to strengthen the relationship between Lithuania and its diaspora. Therefore, in 2011, the "Global Lithuania" programme was launched. Its main goals are: 1) to encourage the maintenance of Lithuanian identity; 2) to promote involvement in the life of Lithuania; 3) to support public diplomacy efforts; 4) to transform the "brain drain" into "brain circulation"; and 5) to strengthen communication (Damusis, 2012). Generally speaking, the programme aims at maintaining links with its community abroad, and therefore matches the reality of Lithuanian diaspora, largely composed of educated individuals oriented towards permanent emigration along with their families.

The Latvian Government has established a return migration policy "to support those Latvian nationals and their families who live abroad, who consider the possibility or have already decided to return and work in Latvia or those who wish to establish their own enterprise or develop business network with Latvia" (Platonova, 2012). Recognising the 
heterogeneous nature of migration patterns, they offer different sorts of practical help to various types of emigrants who wish to return to Latvia.

\section{Conclusion}

The governments of the three Baltic States consider their high emigration to be a serious problem. On the other hand, they also see emigration as a potential resource to support long-term economic growth. Through various programmes they are actively trying to mobilise the financial resources and human capital of the diaspora. Baltic States do not have to start from scratch developing effective programmes to engage diasporas for the purpose of national economic development. They can build on a large body of knowledge and previous experience from other institutions and countries.

To a large extent, the economic and social situation in the country of origin and the characteristics of the migrants themselves (age, level of education, family status, long- or short-term stay abroad) determine the feasibility of diaspora programmes.

The forces driving recent emigration from the Baltic States are different from those of the past, and pose specific challenges. Emigration is strongly related to declining economic opportunities and worsening socio-economic conditions. The emigrant population is consequently evolving in terms of age, education, family status etc. In order to develop realistic diaspora policies, accurate information about the nature and profile of recent emigration from the Baltic countries is necessary. Fortunately, such information is becoming increasingly available.

Programmes and initiatives that encourage emigrants to return are difficult to implement. To some extent, there is a need to provide general information about the labour market situation in the home country. The average emigrant is a young, mediumskilled male, but there is also wide heterogeneity, and students, professionals, circular migrants all have different needs. For those who return, initiatives for labour market reintegration need to reflect these needs. Policies should not unfairly favour emigrants over non-emigrants. This, of course, does not rule out language support and skill recognition for returning emigrants and their families.

Government policies aim at mobilising the human capital and financial resources of the diaspora. The Latvian case shows that the propensity among university-educated Latvians to emigrate permanently increases during times of economic decline. Therefore, not only the probability of investment through remittances, but also the transferability of human capital as a result of emigration should be questioned. This underscores the need for precise data on migration patterns.

Kaczmarczyk's (cf. Chapter 5) example of young Polish emigrants who, after returning to Poland, are more likely than their peers to end up unemployed, shows that "mobilising human capital" is easier said than done. Emigration from the Baltics involves a substantial number of young and low-skilled workers who, like many of their Polish counterparts, will therefore probably fill low-skilled positions upon their return. Hence, a skill transfer is unlikely to occur. Since many of the emigrants will not return, the diasporas of countries in the region are expected to grow. This can be positive, especially if they stay attached to the country of origin. However, maintaining links with the diaspora requires ongoing investment. Business networks require continuous maintenance; political involvement requires infrastructure; identifying and networking professionals requires effort; language training requires ongoing support to teachers, students, and schools. Systematic evaluation of these investments should be taken into 
account in assessing policy impact. State-led and grassroots initiatives each have a role to play. Employers develop initiatives in matching the skills of returning migrants to labour market needs, and business networks play a role in attracting investments and leveraging human and financial capital to promote economic growth, opening markets and fostering innovation. State institutions need to be able to evolve to meet changing economic circumstances and flows of emigration. 


\section{References}

Adams, R. and J. Page (2003), "International Migration, Remittances and Poverty in Developing Countries", World Bank Policy Research Working Paper, No. 3179, December.

Anniste, K., T. Tammaru, E. Pungas and T. Paas (2012), "Dynamics of Educational Differences in Emigration from Estonia to the Old EU Member States", NORFACE Migration Discussion Paper, No. 2012-17.

Carling, J. (2008a), "Interrogating Remittances: Core Questions for Deeper Insight and Better Policies", in S. Castles and R.D. Wise (eds), Migration and Development: Perspectives from the South, International Organization for Migration, Geneva, pp. 43-64.

Carling, J. (2008b), "The Determinants of Migrant Remittances", Oxford Review of Economic Policy, Vol. 24, No. 3, pp. 581-598.

Da Fonseca, E. (2012), "Political Representation of Nationals Abroad", Presentation at the international conference on "The Economic Impact of Emigration in Latvia and the Other Baltic Countries: Challenges and Policy Implications", co-organised by the Latvian Ministry of Foreign Affairs and the OECD, 17 December 2012, Riga.

Damusis, G. (2012), "Global Lithuania: From challenge to opportunity”, Presentation at the international conference on "The Economic Impact of Emigration in Latvia and the Other Baltic Countries: Challenges and Policy Implications", co-organised by the Latvian Ministry of Foreign Affairs and the OECD, 17 December 2012, Riga.

De Haas, H. (2007), "Remittances, Migration and Social Development: A Conceptual Review of Literature", Social Policy and Development Programme Paper, No. 34, UNRISD, Geneva.

De Haas, H. (2006), "Engaging Diasporas. How Governments and Development Agencies Can Support Diaspora Involvement in the Development of Origin Countries. A study for Oxfam Novib", accessible online at www.heindehaas.com/ Publications/de\%20Haas\%202006\%20-\%20Engaging\%20Diasporas.pdf.

Düvell, F. and D. Vogel (2006), "Polish Migrants: Tensions Between Sociological Typologies and State Categories", in A. Triandafyllidou (ed.), Contemporary Polish Migration in Europe. Complex Patterns of Movement and Settlement, Edwin Mellen Press, Lewiston, United States, pp. 267-289.

Eade, J., S. Drinkwater and M. Garapich (2007), "Class and Ethnicity: Polish Migrant Workers in London. Full Research Report. ESRC End of Award Report. RES-000-221294", Economic and Social Research Council, Swindon. 
Engbersen, G. (2012), "Migration Transitions in an Era of Liquid Migration. Reflections on Fassmann \& Reeger", in M. Okólski (ed.), Europe: The Continent of Immigrants: Trends, Structures and Policy Implications, Amsterdam University Press, Amsterdam, pp. 91-105.

Engbersen, G., A. Leerkes, I. Grabowska-Lusinska, E. Snel and J. Burgers (2013), "On the Differentiated Attachments of Migrants from Central and Eastern Europe. A Typology of Labour Migration", Journal of Ethnic and Migration Studies, Vol. 39, No6, pp. 959-981, http://dx.doi.org/10.1080/1369183X.2013.765663.

Friberg, J.H. (2013), "The Stages of Migration. From Going Abroad to Settling Down: Post-accession Polish Workers in Norway", Journal of Ethnic and Migration Studies (forthcoming).

Gardner, K. (2012), "Diaspora Partnerships: An Irish Experience”, Presentation at the international conference on "The Economic Impact of Emigration in Latvia and the Other Baltic Countries: Challenges and Policy Implications", co-organised by the Latvian Ministry of Foreign Affairs and the OECD, 17 December 2012, Riga.

Gornischeff, P. (2012), "Quo Vadis Estonian Talen? Talents Back Home. Lessons Learned", Presentation at the international conference on "The Economic Impact of Emigration in Latvia and the Other Baltic Countries: Challenges and Policy Implications", co-organised by the Latvian Ministry of Foreign Affairs and the OECD, 17 December 2012, Riga.

Grabowska-Lusinska, I. and M. Okólski (2009), Emigracja Ostatnia?, Wydawnictwo Naukowe Scholar, Warsaw.

Handjiski, B. (2012), "Remittance Trends, Diaspora Bonds and Remittance-Backed Securities", Presentation at the international conference on "The Economic Impact of Emigration in Latvia and the Other Baltic Countries: Challenges and Policy Implications", co-organised by the Latvian Ministry of Foreign Affairs and the OECD, 17 December 2012, Riga.

IOM - International Organization for Migration (2011), "Migration Profile: Lithuania”, accessible online at www.iom.lt/documents/Migration profile_EN.pdf.

IOM (2006), "Engaging Diasporas as Development Partners for Home and Destination Countries: Challenges for Policymakers", IOM, Genera, accessible online at www.iom.int/jahia/webdav/site/myjahiasite/shared/shared/mainsite/published docs/se rial publications $/ \mathrm{mrs} 26 \% 20$ interior.pdf.

Ketkar, S.L. and D. Ratha (2006), "Global Economic Prospects 2006: Economic Implications of Remittances and Migration. Development Finance Via Diaspora Bonds Track Record and Potential", World Bank Policy Research Working Paper, No. 4311, Washington, DC.

Mereuta, C. (2012), "Mobilising Migrant's Skills and Recourses - The Case of Romania", Paper prepared for the international conference on "The Economic Impact of Emigration in Latvia and the Other Baltic Countries: Challenges and Policy Implications", co-organised by the Latvian Ministry of Foreign Affairs and the OECD, 17 December 2012, Riga.

Newland, K. and P. Erin (2004), "Beyond Remittances: The Role of Diaspora in Poverty Reduction in their Countries of Origin", A Scoping Study by the Migration Policy Institute for the Department of International Development. 
OECD (2012), Connecting with Migrants: A Global Profile of Diasporas, OECD Publishing, Paris, http://dx.doi.org/10.1787/9789264177949-en.

Platonova, I. (2012), "Supporting Measures to Foster Return Migration", Presentation at the international conference on "The Economic Impact of Emigration in Latvia and the Other Baltic Countries: Challenges and Policy Implications", co-organised by the Latvian Ministry of Foreign Affairs and the OECD, 17 December 2012, Riga.

Reid, J. (2012), "GlobalScot: An International Business Network", Presentation at the international conference on "The Economic Impact of Emigration in Latvia and the Other Baltic Countries: Challenges and Policy Implications", co-organised by the Latvian Ministry of Foreign Affairs and the OECD, 17 December 2012, Riga.

Saxe, L. et al. (2011), "Jewish Futures Project. The Impact of Taglit-Birthright Israel”, accessible online at www.birthrightisrael.com/TaglitBirthrightIsraelStory/Research/ Documents/Jewish.Futures.02.08.11.pdf.

Schnytzer, T. (2012), "Birthright Israel", Presentation at the international conference on "The Economic Impact of Emigration in Latvia and the Other Baltic Countries: Challenges and Policy Implications", co-organised by the Latvian Ministry of Foreign Affairs and the OECD, 17 December 2012, Riga.

Vehkanen, M. (2012), "Finnish Language and Culture", Presentation at the international conference on "The Economic Impact of Emigration in Latvia and the Other Baltic Countries: Challenges and Policy Implications", co-organised by the Latvian Ministry of Foreign Affairs and the OECD, 17 December 2012, Riga. 



\title{
Chapter 2
}

\section{Emigration from Estonia: Recent trends and economic impact}

\author{
Veronika Kaska
}

This chapter analyses the general demographic trends causing concern in Estonia: decreasing population and increasing emigration flows, especially among those of working age. The implications of accession to the European Union and the gradual opening of European labour markets are assessed, in terms of the characteristics of emigrants. The profile of emigrants is explored (age, education, etc.). Possible economic implications of emigration are discussed, in light of data limitations. Government policy in the area is described, as well as specific initiatives to favour return. 


\section{Introduction}

The total population in Estonia has diminished by almost 7\% over the past 15 years due to low birth rates and negative net migration. The Estonian population is ageing; the share of children and young adults has dropped dramatically during the past decade (OECD, 2011).

In recent years, heated public debate has occurred over whether emigration constitutes a problem for Estonia and if so, to what extent. Debate may also be fuelled by a lack of reliable statistical data necessary to assess emigration and its effects. One question is whether the impact is due to emigration itself, or to the fact that people do not come back. For example, a 2009 youth conference of the Estonian Co-operation Assembly considered the latter, rather than the former, as constituting a problem (Tamm, 2009). Emigration has also emerged as a political issue in Estonia, since the Estonian Centrist Party, in their 2011 election campaign, ${ }^{1}$ cited high unemployment and people (especially doctors) going abroad to find work.

This chapter looks at the trends in emigration from Estonia and uses available data to sketch the profile of the average emigrant. The chapter will also give a brief overview of the measures taken to encourage the return Estonian migrants. Finally, the author draws conclusions regarding the economic impact of emigration on Estonia.

\section{General data on emigration from Estonia}

Having regained independence after the collapse of the Soviet Union in 1991, Estonia became a country of emigration, as relocation to Western European countries became easier. Since then, Estonia has experienced two significant waves of emigration, the first in the 1990s and the second in the 2000s. Emigration from Estonia to the older EU member states $^{2}$ increased in the 2000s compared to the 1990s (Pungas et al., 2012). This chapter focuses on the second wage of emigration, concentrating on data from 2004 on. This date is also used because the collection of migration data by Statistics Estonia became more systematic following the entry into force in 2002 of a law regulating resident registration (Anniste, 2009). Nonetheless, data on emigration are still incomplete, as people do not always deregister in Estonia when moving to another country. This is a common phenomenon in most emigration countries (Anniste et al., 2012).

A much-anticipated census was carried out in Estonia between 31 December 2011 and 31 March 2012 (Statistics Estonia, 2011). The results of the census confirmed what was already widely assumed and in line with general demographic trends affecting most countries in Europe.

The trends confirmed by the census are declining population (especially in the age the group 15-64, namely working age), declining births, and an increase in the number of older people. Figure 2.1 illustrates Estonia's population, based on the 2011 census data. A total of 1294236 residents were counted, down from 1370052 in 2000. Moreover, according to Statistics Estonia, preliminary data show that the estimated size of the population in Estonia on 1 January 2013 was 1286540 (and has thus decreased by another $0.6 \%$ ). The decline observed was mainly attributed to increases in emigration and deaths. In 2012, 10871 persons emigrated, 4657 more than the previous year. During the same period, 4416 persons immigrated to Estonia. Thus, in 2012 Estonia recorded the highest negative net migration since the year 2000 (6 455) (Statistics Estonia, 2013).

A country's population increases as a result of births or immigration, and decreases due to deaths or emigration (Narusk, 2012). The aforementioned trends, coupled with the fact that Estonia is increasingly an emigration country, may well explain the 5.5\% decline in the size of the country's population between 2000 and 2011. 
Figure 2.1. Estonian population pyramid, 2000 vs. 2012

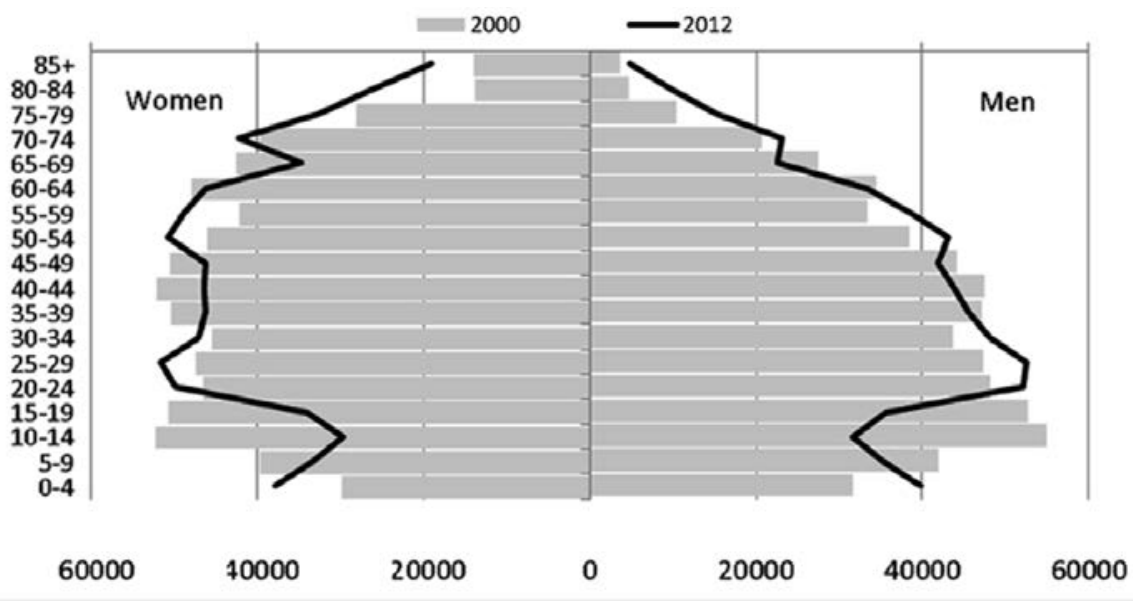

Source: Statistics Estonia.

Population decline between 2000 and 2011 was in fact greater than that estimated by Statistics Estonia, according to which, during the intercensual period, Estonia's population decreased by 54333 persons, with 32409 persons lost due to negative natural increase and 22024 persons lost due to negative net migration. The main reasons for the difference between the census figures and the Statistics Estonia estimates are unregistered migration and census non-compliance. It is estimated that about $2.1 \%$ of permanent residents were not enumerated in the 2011 census for various reasons (Narusk, 2012). The census did reveal however, that 30444 residents (2.4\% of the total population) have left Estonia and moved abroad (ibid.). This number includes both registered and unregistered migration. Unfortunately, these are not exact figures, due to limits in census coverage, but they do provide a better indication of the magnitude of emigration (ibid.). Available data (Figure 2.2) shows that migration to and from Estonia is not large. Still, net migration has remained negative throughout the past eight years, and 2011 emigration data show that the annual number of people who emigrate corresponds to close to $0.5 \%$ of the total population of Estonia.

Figure 2.2. Migration to and from Estonia, 2004-11

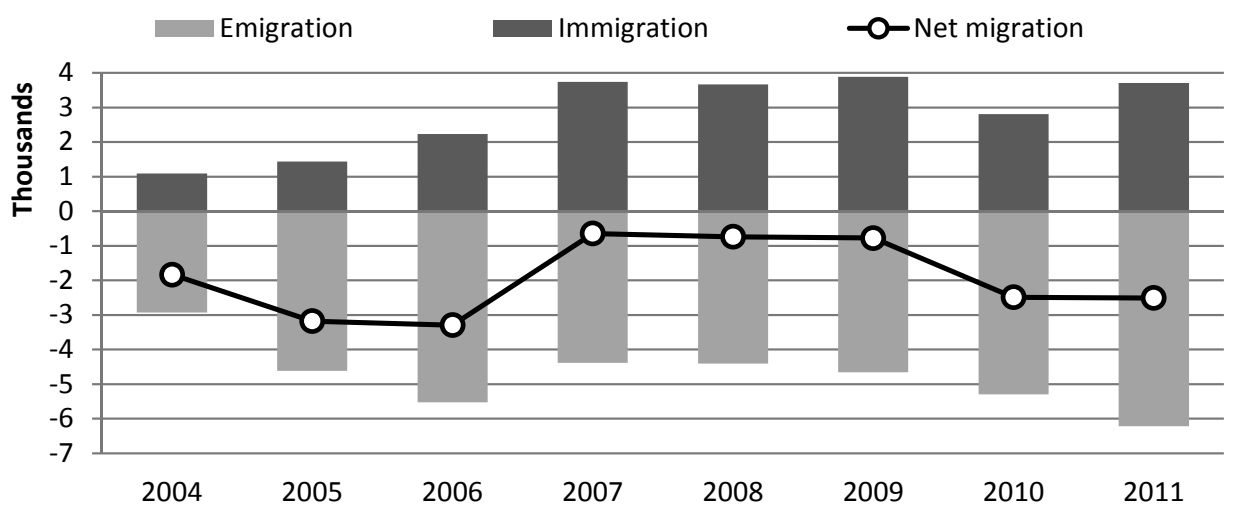

Source: Statistics Estonia. 


\section{Emigrant population profile}

Due to reasons explained above, the available data on emigration are ambiguous. Nonetheless, a few recent studies provide a good basis for putting together an emigrant population profile.

The Bank of Estonia has analysed the structure of the emigrant population on the basis of a survey (Randveer and Rõõm, 2009) carried out in January 2008. The survey targeted company managers and its aim was to collect information on work-related migration to and from Estonia in 2007. The methodological approach to data collection adopted in this study, namely the administration of questionnaires to company managers, is new, and has the limitation that the sample is restricted to employed persons. The survey focussed mainly on emigration patterns: Which types of workers emigrate from Estonia? Are they predominantly young people? What is their average level of education? Are they mostly men or women, native Estonians or people of other nationalities? The survey covered a significant part of the Estonian labour force. The companies that participated in the survey employed 54500 people, corresponding to approximately $9 \%$ of Estonian wage earners (ibid.).

International experience reveals that the likelihood of emigration is higher among individuals that are young, male and have higher education. Studies analysing immigration from new ${ }^{3}$ to old EU member states to the old member states of the European Union have confirmed that indeed younger people are more likely to move than older people (Randveer and Rõõm, 2009). A World Bank report (2006) however, argues that the migration of younger people decreases in the presence of restrictions on immigration (e.g. requirements of tertiary education or substantial work experience).

The gradual lifting of restrictions on immigration after Estonia joined the European Union in 2004 affected the structure of the Estonian emigrant population as well.

The Bank of Estonia survey found that the average migrant from Estonia is a young person (between 15-34 years of age), a blue-collar worker and male. Results also indicated that the tendency to emigrate was strongest among construction sector employees (Randveer and Rõõm, 2009).

The findings were in line with those of another survey, on migration intentions and behaviour among Estonian residents, conducted in 2010 on behalf of the Ministry of Social Affairs. This survey found that working in another country tends to attract people aged 15-24. The preferred jobs abroad were predominantly less skilled, and included the following occupations, in order of preference: construction worker, other elementary worker, cleaner and room attendant, customer service assistant, or chauffeur and bus driver. The preferred sectors of employment abroad were construction, transport and storing and processing industry. Men were three times more likely than women to express a definite wish to work abroad in the future (17.5\% and $6.5 \%$, respectively), and were also more likely to have taken practical steps to that end (Veidemann, 2010).

A study conducted among emigrants from Estonia to Finland confirmed that, compared to the general population of Estonia, migrants are significantly younger and their educational level is lower. The proportion of university-educated people in the emigrant population is much lower than in the general Estonian population, and has further decreased since Estonia joined the European Union in 2004 (Anniste et al., 2012). 
These findings are at odds with evidence both from other countries and from earlier emigration periods, which overwhelmingly show that the tendency to migrate is greater among people with higher education (Randveer and Rõõm, 2009).

This contradiction may be due to the link between restrictions on immigration and the age of emigrants, as suggested in the above-mentioned World Bank report. The gradual lifting of restrictions on immigration by old member states following Estonian accession to the European Union may have increased the proportion of younger and low-skilled individuals (characteristics which often coincide) among Estonian emigrants. These individuals had not been able to qualify under the labour migration regimes in most EU countries prior to accession. Other factors that may have contributed to this phenomenon are the demand for immigrant workers in low-skilled occupations in Western Europe, and the fact that such workers stood to experience a more substantial relative increase in earning after moving abroad (Randveer and Rõõm, 2009; Anniste et al., 2012).

Surveys estimating the emigration potential in the Estonian working-age population were also conducted in 2000, 2003 and 2006. Data from these surveys were compared with data from the 2010 survey to assess current and future trends. The 2010 survey confirmed that, even in times of economic crisis, people view working abroad as a last resort, Compared to earlier years, in 2010 the number of people intending to work abroad had increased. While in 2006 the share of the working-age population who had considered going abroad was $26 \%$ and the estimated migration potential $3.9 \%$ (about 36000 people), in 2010 as many as $38 \%$ had considered migration, and the estimated migration potential had increased to $8.5 \%$ (about 77000 people). Noteworthy is also the fact that $13 \%$ of potential migrants would consider leaving their state of residence (or country of origin) permanently (Veidemann, 2010). It should be borne in mind, of course, that intentions to migrate are more common than migration itself. Estonian emigrants preferred Nordic destination countries, particularly Finland, which has remained the main destination country for westward migration from Estonia. Previously attractive destinations like Ireland and Great Britain have lost their importance. For young people, Australia and the United States of America are popular destinations (Veidemann, 2010; Anniste et al., 2012).

It may thus be concluded that the average migrant from Estonia is a male blue-collar worker aged 15-34, moving to Finland to work in the construction sector.

\section{Measures to encourage return}

Analyses of international migration have recognised that return migration is a central issue in understanding the implications of the international mobility of workers for the origin country. More than $30 \%$ of migrants return to their home country within two decades, and many of them go abroad to enhance their skills (Mayr and Peri, 2009).

Similarly, there is evidence that a large portion of recent migration from new to old EU member states is temporary in nature (Randveer and Rõõm, 2009). This may be due to the motives behind the decision to migrate, the most prevalent of which is the wish to earn a higher salary (Veidemann, 2010). This push factor means that many migrants are undeterred by the prospect of working in a job which does not match their qualifications, as long as they are earning more than they were in their origin country. The frequent consequence is the deskilling of migrant workers (Anniste et al., 2012).

One survey conducted among Estonians in Finland showed that the probability of return is especially high during the first five years after arrival and decreases steadily thereafter. The probability of return was greater for those offered employment in Estonia 
in a more prestigious occupation. Unemployment often increases the probability of migrant return, but in the case of Estonian migrants in Finland, the inclination of the unemployed to leave Finland was much lower than that of the employed, possibly due to better welfare benefits in the host state. Interestingly, the level of education was not associated with the intention to return. Adults were generally more motivated to improve their education once in the country of destination, even if studying was not the primary goal of their departure from Estonia. No association was found between migrants' intentions to return and their occupational category or income (Pungas et al., 2012).

Considering phenomena such as the risk of deskilling, or the potential for upskilling abroad, emigration countries are clearly interested in encouraging migrants to move back home.

In 2008, Estonian citizens made up $48 \%$ of immigrants to Estonia, a share of nationals among immigrants second only to Poland (75\%) and Lithuania (68\%) (Oblak Flander, 2011). The number of Estonian nationals fell slightly in 2009 and 2010, but peaked in 2011, when returning nationals constituted over 50\% of immigrants to Estonia (see Figure 2.3).

The incumbent Government of the Republic of Estonia, a coalition government formed by the Reform Party and the Pro Patria and Res Publica Union, agreed upon a Coalition Programme for the years 2011-15. ${ }^{4}$ While widely acknowledging population decline and increasing emigration as problems, the programme does not contain specific measures to contrast emigration or lure Estonian migrants back home. Instead, it aims to make Estonia a better place to live by increasing the quality of life and stimulating the creation of a living environment with the intended result of increasing life expectancy and births. ${ }^{5}$

Although the Coalition Programme does not include specific measures to be implemented, a population policy is in force, as defined in "The Principles of Estonian Population Policy for 2009-13". 6 This document discusses the importance of measures to encourage return migration, including: informing people of Estonian descent living outside of Estonia about the possibilities of studying in Estonia, and of returning to Estonia (including eligibility for counsel and financial aid), the acquisition and restoration of Estonian citizenship and the facilitation of re-integration.

Figure 2.3. Immigrants to Estonia, by nationality, and the share of Estonian nationals among immigrants to Estonia, 2004-11

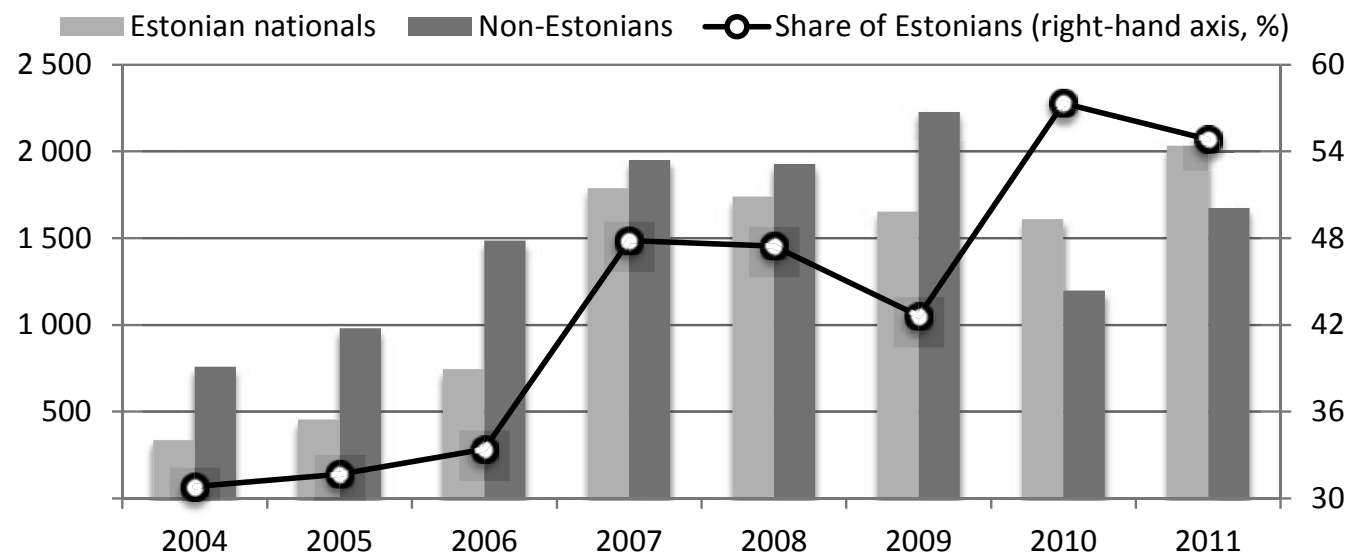

Source: Statistics Estonia. 
The state also emphasizes the importance of developing and maintaining cultural relations with Estonian communities abroad. The government has therefore adopted the Compatriots' Programme in 2003 (including a website ${ }^{7}$ ) to co-ordinate the work of different ministries in supporting Estonian communities abroad as the carriers of cultural identity.

Two measures have been implemented in order to encourage return migration to Estonia. The first, return support, has been in place since 2004 and has aided in the return of 636 people. The second was a two-year project to attract highly educated Estonians back, which resulted in the return of 27 individuals. Though both measures have the same aim, the target groups of these two measures are quite different.

\section{Return support}

An established measure for motivating Estonians all over the world to move back to Estonia is financial and other kinds of "return support". Return support is provided by the Integration and Migration Foundation Our People.

The foundation was originally established by the Republic of Estonia in $1998^{9}$ and is currently managed by the Ministry of Culture. ${ }^{10}$ Its statutory purpose ${ }^{11}$ is to initiate and support activities related to immigration and emigration, including common activities involving both Estonians and non-Estonians, aimed at facilitating the integration of non-Estonians into Estonian society. The foundation also counsels people returning to or leaving Estonia on migration issues, and offers them financial support, if necessary, in case of return migration, emigration or expulsion. Under the Constitution of the Republic of Estonia, every ethnic Estonian and Estonian citizen has the right to settle in Estonia. The terms "ethnic Estonian" and "Estonian citizen" have different meanings. Ethnicity is primarily a matter of self-definition. Possible objective criteria for establishing ethnicity can be knowledge of the Estonian language or direct descent from an ethnic Estonian, but these characteristics do not define someone unequivocally as an Estonian. ${ }^{12}$ This means that the target population of return support is quite large.

Integration and Migration Foundation "Our People" supports return migration to Estonia by paying relocation support (up to EUR 2000 per adult) to ethnic Estonians and Estonian citizens who have resided abroad for at least ten years or were born there.

Application for return support can be submitted only after entry into the Population Register of Estonia, but no later than six months after resettling in Estonia. An entry in the Population Register is made if a person is an Estonian citizen or holds a valid residence permit (for non-EU citizens) or right (for EU citizens and their family members). ${ }^{13}$

Eligibility criteria for return support are:

- emigration from Estonia at least ten years ago or birth in a foreign country

- the person has retained ties with the Estonian culture or wishes to join it

- the person requires financial aid due to his or her financial or social background

- in the course of the programme it has been noted that the main reasons for returning to Estonia are family reunification and better living and work prospects (Kaska, 2010). 
As shown in Table 2.1, the number of returning Estonians applying for support has been rather constant during the last eight years. An exceptionally large number of people returned in 2007 and 2008, which may be explained by rapid economic growth and the subsequent availability of jobs.

Table 2.1. Return support statistics, 2004-11

\begin{tabular}{lrrrrrrrr}
\hline & $\mathbf{2 0 0 4}$ & $\mathbf{2 0 0 5}$ & $\mathbf{2 0 0 6}$ & $\mathbf{2 0 0 7}$ & $\mathbf{2 0 0 8}$ & $\mathbf{2 0 0 9}$ & $\mathbf{2 0 1 0}$ & $\mathbf{2 0 1 1}$ \\
\hline $\begin{array}{l}\text { Number of recipients of } \\
\text { return support }\end{array}$ & 36 & 12 & 40 & 144 & 242 & 42 & 66 & 54 \\
\hline $\begin{array}{l}\text { Total amount paid (EUR) } \\
25373\end{array}$ & 12591 & 50810 & 128143 & 121911 & 44419 & 51257 & 55070 \\
\hline $\begin{array}{l}\text { Average support received } \\
\text { per applicant (EUR) }\end{array}$ & 705 & 1049 & 1270 & 890 & 504 & 1058 & 777 & 1020 \\
\hline
\end{tabular}

Source: "Integration and Migration Foundation Our People. Return Support", available online at www.meis.ee/tagasiranne-eng, accessed on 7 November 2012.

Despite the large target group, restrictive criteria limit the number of potential applicants for relocation support, especially in light of the fact that the probability of return migration decreases after five years abroad (Pungas et al., 2012). To improve the efficacy of the programme, it may be worth reassessing the eligibility criteria for return support, e.g. shortening the required time abroad to five years. If abuse of the measure is feared, then additional post-return residence requirements may be imposed (e.g. five years minimum residency in Estonia prior to new relocation, etc.).

\section{"Talents Back Home!"}

Another measure to attract those who had emigrated was the two-year project "Talents Back Home!" carried out by the Estonian Chamber of Commerce and Industry as of October 2010 and financed by the European Social Fund.

The aim of the project was to entice students who had gone to study in universities abroad, graduates of foreign universities and Estonian citizens who had obtained a significant work experience abroad, to come back to Estonia, by offering them work and self-realisation in either the private or the public sector. ${ }^{14}$ Prior research showed that there were between 4000 and 4500 young Estonians studying abroad, and that about $89 \%$ of them were ready to return to Estonia if a good offer came along. Timing was especially important for the target group, e.g. a job offer in time for graduation or when the children reach school age. The main elements cited by respondents as possible reasons to return were (Niitra, 2012):

- pay which would guarantee a good standard of living (82.9\%)

- challenge $(65.3 \%)$

- work environment $(64.8 \%)$

- a job with an international dimension (61.1\%)

- closeness of family and friends (56.5\%)

- begin career at a higher position (39.7\%)

- $\quad$ ease of return $(23.9 \%)$. 
At the beginning of October 2010, the Estonian Chamber of Commerce and Industry launched an internet portal (www.talendidkoju.ee) where talented young adults studying abroad could find information regarding work and internship offers in Estonia, and where companies could use the contact network of those studying abroad in order to find employees. As early as mid-October 2010 it was reported that interest in the project had been greater than anticipated. Soon, 220 highly qualified Estonians from 35 different countries had registered at the website and expressed an interest in returning to Estonia (Kass, 2010).

The project ended in October 2012, with 27 people having returned to Estonia from abroad. The authors of the final report conclude that, considering the difficulty of return, the result was good. The offer of a challenging and well-paid job was found to be a prerequisite for return. A total of 743 people, most of whom hold Master's or Doctoral degrees, uploaded their resumes on the website (Traks, 2012). This suggests that the programme attracted the highest educated.

\section{Economic impact}

Emigration has become increasingly significant, not only because of its scale but also because of the mounting evidence of its impact on development (World Bank, 2006). The movement of people and jobs means that the challenge of matching skills and jobs, while primarily country specific, also has a global dimension. Migration has implications for living standards and productivity at both the sending and the receiving ends, and they can transform families and entire communities, for better or for worse (World Bank, 2012). Conversely, since the beginning of the global economic crisis in 2007-08, numerous forecasts have been made about the potential effects of the crisis and of ensuing recovery on migration. These predictions, however, pertained to developing countries where the sudden return of large numbers of migrant workers may seriously compromise economic stability, due both to an inability of local markets to absorb them, and to the loss of remittances previously sent back by the now returning migrants. Interestingly, data from the United Kingdom show that, unlike migrants from Africa, Bangladesh and Pakistan, Eastern and Central European nationals were relatively unscathed by the rise in joblessness due to the economic crisis (IOM, 2011). This may explain the ever increasing emigration from Estonia and the stable numbers of returning nationals throughout the economic crisis. The finding that migrants who have a job are more likely to have intentions to return implies that origin countries stand to gain from intra-European migration, while destination countries stand to lose (Mayr and Peri, 2010). These people have accumulated foreign work experience that could be an important factor in stimulating growth in their countries of origin (Pungas et al., 2012).

Similar positive conclusions were drawn by the Estonian Minister of Economic Affairs and Communications, Mr. Juhan Parts, when answering an inquiry by six members of the Estonian Parliament, the Riigikogu, on 14 June 2010. The inquiry addressed the cost to the Estonian economy of worker migration, and included the following questions: How has worker migration influenced the Estonian economy and can such emigration threaten the development of the Estonian economy? What measures is the Ministry of Economic Affairs and Communications planning to take in order to ensure that top specialists do not leave Estonia? How can the Ministry ensure that those who leave Estonia for employment reasons come back to Estonia after the crisis?

The Minister of Economic Affairs and Communications found that the number of emigrants is too small to significantly influence Estonia's wage and employment levels. 
He added however, that temporary emigration might prove useful in case of high unemployment. Positive aspects of temporary emigration are remittances, and the enhancement of people's knowledge and skills. Estonia should therefore not try to suppress emigration, but rather try to encourage return through projects like "Talents Back Home!". The influence of permanent migration, on the other hand, is negative, due to brain drain, decreasing productivity, and the loss of investments made by the state in educating those who end up leaving the country. ${ }^{15}$

As we have seen, adult Estonian emigrants were more motivated than younger emigrants to improve their education once in Finland. Another finding was that the willingness to return to Estonia, on the part of individuals who had obtained at least part of their education in Finland, decreased considerably as the duration of their stay in Finland increased (see note 15). Thus emigration holds promise for the origin country, since migrants obtain valuable work experience and may improve their level of education, but only if the migrant's stay in the destination country is temporary, even short-term, in nature.

As noted, the emigrant population is mostly made up of young blue-collar male workers. The portion of blue-collar workers among emigrants increased in 2010 as compared to 2006 (Veidemann, 2010). These workers also represent the biggest share of registered unemployed persons in Estonia. ${ }^{16}$ Unemployment in the third quarter of 2012 was 9.7\% (68 000 persons) (Statistics Estonia, 2012). In the first half of 2012, levels of education among the registered unemployed were as follows: $17 \%$ with primary education, $57 \%$ with secondary education, and $29 \%$ with vocational secondary or higher education (Viilman and Soosaar, 2012). The European Commission has pointed out that one of the main challenges for Estonia is an insufficient supply of competent human capital. As one-third of the labour force has no professional education, the available skills and qualifications do not match labour market needs (European Commission, 2012).

In light of the apparent compatibility between the profile of the migrant population, and that of the population of (registered) unemployed people in Estonia, would it thus be possible to conclude that emigration is beneficial to the Estonian economy and labour market? To some extent perhaps, but due to the relatively small number of migrants, according to the Minister of Economic Affairs and Communications, such effect would in any event not be significant.

It has been shown that migrants wish to improve their education while in the country of destination. Could Estonia then expect to gain a more experienced and qualified labour force once the emigrants return? Available data do not provide enough of a scientific basis for such a conclusion. In any case, in light of the small emigration flows, it may only come true if a majority of those leaving Estonia do in fact improve their level of education and do eventually return.

\section{Conclusion}

General demographic trends that are causing concern in many countries around the world - decreasing population and increasing emigration flows - can also be observed in Estonia. These trends are especially evident in the working-age population. Accession to the European Union and the gradual opening of European labour markets has meant that more Estonians, especially young and low-skilled workers, move abroad, either temporarily or permanently. As studies indicate that the average emigrant is a blue-collar male, brain drain (the loss of highly qualified individuals) may not constitute a major 
problem. Data is still insufficient, however, to firmly make such a claim. The Estonian diaspora in Finland - Estonian emigrants' major destination country - has been studied thoroughly. These studies provide a good basis for understanding the reasons and nature of Estonian emigration to Finland, but their results cannot necessarily be generalised to all Estonian emigrants.

While aware of the negative aspects of emigration, especially if permanent, the Estonian Government also sees the advantages that can be gained from temporary migration - foreign work experience, improved skills and remittances. The government does not consider it necessary to stop people from leaving Estonia, but has taken measures to encourage the return of Estonian emigrants. Without necessarily attributing the fact to the measures in question, it should be noted that much of the immigration to Estonia is actually return migration.

At any rate, in the absence of reliable data definite assertions cannot be made regarding the influence of emigration to Estonia's economy. The Minister of Economic Affairs and Communications considers the number of people emigrating too small to have any significant impact on either unemployment or wages. Still, with a population as small as that of Estonia's, even the flutter of a butterfly's wings may have an effect. 


\section{Notes}

1. Available on Youtube at www.youtube.com/watch? $\mathrm{v}=3 \mathrm{xFECQcY5L8}$, accessed on 7 November 2012.

2. Denotes those countries that have been members of the European Union prior to 2004, i.e. France, Belgium, the Netherlands, Germany, Luxembourg, Austria, Italy, Greece, Portugal, Spain, Denmark Sweden, Finland, Ireland and the United Kingdom.

3. Denotes those countries that joined the European Union in 2004.

4. The "Coalition Programme of the Pro Patria and Res Publica Union and the Reform Party" is available online at https:/valitsus.ee/UserFiles/valitsus/et/valitsus/ tegevusprogramm/valitsuse-tegevusprogramm/Valitsusliidu\%20programm\%2020112015.pdf, accessed on 7 November 2012.

5. "Report of the Prime Minister Candidate to the Riigikogu on the Bases of Forming a Government", available online at http://valitsus.ee/et/valitsus/peaminister-jaministrid/andrus-ansip/peaministri-koned-ja-seisukohad/31242/peaministrikandidaadi -ettekanne-riigikogule-valitsuse-moodustamise-alustest-5-aprill-2011, accessed on 7 November 2012.

6. "The Principles of Estonian Population Policy 2009-2013", available online at www.valitsus.ee/failid/Rahvastikupoliitika alused muudetud.pdf, accessed on 14 November 2012.

7. Available online at www.eesti.ee/rahvuskaaslased/index.php?lang=en. accessed on 14 November 2012.

8. "Integration and Migration Foundation Our People. Return support", available online at www.meis.ee/tagasiranne-eng, accessed on 7 November 2012.

9. 31 March 1998 Order No. 263 of the Government of the Republic "Establishment of the Non-Estonian Integration Foundation”, RT I 1998, 33, 471.

10. 11 June 2009 Order No. 236 of the Government of the Republic "Amendments of Orders of the Government of the Republic in Relation to Handing Over Tasks of a Minister", RTL 2009, 48, 700.

11. "Statute of the Integration and Migration Foundation Our People", Directive No. 303 of the Minister of Culture, approved on 25 August 2010, available online at www.meis.ee/pohikiri, accessed on 14 November 2012.

12. The Constitution of the Republic of Estonia, Commented Edition, Second supplemented edition (2008), Juura Publishing House, Tallinn.

13. Available online at www.meis.ee/pohikiri, accessed on 14 November 2012.

14. Press Release of the Estonian Chamber of Commerce and Industry, available online at www.koda.ee/uudised/pressiteated/kaubandus-toostuskoja-talendid-koju-projektkutsub-noori-eestlasi-kodumaale-toole/, accessed on 14 November 2012. 
15. Shorthand records of the 7th sitting of the 11th Riigikogu, 14 June 2010, available online at www.riigikogu.ee/?op=steno\&stcommand=stenogramm\&day=15\&date $=1276517100 \&$ pkpkaupa $=1 \&$ paevakord $=6701 \#$ pk6701, accessed on 7 November 2012.

16. Based on data from the Estonian Unemployment Insurance Fund 31 October 2012, available online at www.tootukassa.ee/index.php?id=13558, accessed on 14 November 2012. 


\section{References}

Anniste, K. (2009), "External Migration of Estonia in 2000-2007", in T. Tammaru and A. Tammur (eds.), Migration, Statistics Estonia, Tallinn.

Anniste, K., T. Tammaru, E. Pungas and T. Paas (2012), "Emigration After EU Enlargement: Was There a Brain Drain Effect in the Case of Estonia?", Faculty of Economics and Business Administration Working Paper Series, No. 87, University of Tartu, www.mtk.ut.ee/orb.aw/class=file/action=preview/id=1158427/febawb87.htm.

European Commission (2012), "Position of the Commission Services on the Development of Partnership Agreement and Programmes in Estonia for the Period 2014-2020”, Ref. Ares (2012)1283813, 30 October 2012.

IOM - International Organization for Migration (2011), World Migration Report 2011: Communicating Effectively About Migration, IOM, Geneva.

Kaska, V. (2010), "Temporary and Circular Migration: Empirical Evidence, Current Policy Practice and Future Options in Estonia", Estonian Academy of Security Sciences, Tallinn.

Kass, M. (2010), "Koju pöördumise vastu tunneb huvi oodatust rohkem talente". Postimees online article, www.postimees.ee/326174/koju-poordumise-vastu-tunnebhuvi-oodatust-rohkem-talente/.

Mayr, K. and G. Peri (2009), "Brain Drain and Brain Return: Theory and Application to Eastern-Western Europe", Department of Economics Vienna Economics Papers, No. 0907, University of Vienna, www.econ.ucdavis.edu/faculty/gperi/publications/ mayr peri sept 09.pdf.

Narusk, E. (ed.) (2012), Quarterly Bulletin of Statistics Estonia, No. 4. Statistics Estonia, available online at http://www.stat.ee/57666.

Niitra, S. (2010), "Enamik välismaal õppivaid noori tahab Eestisse tagasi", Tarbija24 online article, www.tarbija24.ee/323216/enamik-valismaal-oppivaid-noori-tahabeestisse-tagasi/.

Oblak Flander, A. (2011), "Immigration to EU Member States Down by $6 \%$ and Emigration Up by $13 \%$ in 2008", Population and Social Conditions, No. 1, Eurostat, Luxembourg.

OECD (2011), Estonia: Towards a Single Government Approach, OECD Public Governance Reviews, OECD Publishing, Paris, http://dx.doi.org/10.1787/ 9789264104860-en.

Pungas, E., O. Toomet, T. Tammaru and K. Anniste (2012), "Are Better Educated Migrants Returning? Evidence from Multi-Dimensional Education Data”, NORFACE Migration Discussion Paper, No. 2012-18, www.norface-migration.org/ publ_uploads/NDP_18_12.pdf. 
Randveer, M. and T. Rõõm (2009), "The Structure of Migration in Estonia: Survey-Based Evidence", Working Paper Series, No. 1, Bank of Estonia, www.eestipank.ee/en/ publication/working-papers/2009/martti-randveer-tairi-room-structure-migrationestonia-survey-based-evidence.

Statistics Estonia (2013), "Press Release No. 9”, 18 January.

Statistics Estonia (2012), "Press Release No. 144”, 14 November.

Statistics Estonia (2011), "Press Release No. 171”, 31 December.

Tamm, M. (2009), "Eesti probleem pole mitte väljaränne, vaid mitte-tagasitulek", Postimees online article, www.postimees.ee/190831/eesti-probleem-pole-mittevaljaranne-vaid-mitte-tagasitulek/.

Traks, K. (ed.) (2012), “Talendid koju!”, Projekt tõi Eestisse tagasi 27 inimest, Juhtimine online article, www.juhtimine.ee/1010730/talendid-koju-projekt-toi-eestisse-tagasi27-inimest/.

Veidemann, B. (2010), "Migration Potential of Working-age Population in Estonia in 2010", Series of the Ministry of Social Affairs, No. 8, www.sm.ee/fileadmin/meedia/Dokumendid/V2ljaanded/Toimetised/2010/series 2010 8eng.pdf.

Viilman, N. and O. Soosaar (2012), "Tööturu ülevaade", Eesti Pank, No. 2, www.eestipank.ee/sites/default/files/publication/20121105_tooturu_ulevaade_2012_2 pa est.pdf.

World Bank (2012), World Development Report 2013: Jobs, World Bank, Washington, DC.

World Bank (2006), World Development Report 2007: Development and the Next Generation, World Bank, Washington, DC. 



\title{
Chapter 3
}

\section{The social and economic impact of emigration on Lithuania}

\author{
Dr. Audra Sipavičienè \\ IOM Vilnius Office
}

and

Prof. Dr. Vlada Stankūnienè

Lithuanian Social Research Centre

This chapter examines migration flows from Lithuania, historically a country with significant emigration. The changing characteristics of this migration since 1990 and their relationship to economic conditions in Lithuania and EU accession are examined. The distinction between declared and undeclared migration is explored. The impact of the 2008-11 economic crisis on migration is described, including its impact on return migration and choice of destination country. The chapter examines the changing characteristics of emigrants, in terms of their age and family situation as well as their education level and employment status. The effect of remittances is discussed, and the chapter concludes with a review of policy responses in Lithuania. 


\section{Introduction}

Socio-economic development and emigration are interrelated and in a relationship of reciprocal causality. On the one hand-socio-economic developments and economic problems are among the main causes of emigration. On the other, emigration, especially mass emigration, as in the Lithuanian case, directly and indirectly influences current and future social and economic development, and in many cases encourages further emigration. Emigration becomes an essential economic strategy, a main source of income for certain portions of the population. The impact of emigration differs depending on the period and on whether the national or the individual/family levels are considered. Nonetheless, in Lithuania, its potential impact on future social and economic development is rarely discussed. There is a widespread faith that return migration - which has yet to occur in large numbers - will mitigate any negative impact. This chapter analyses migration as an integral part of social and economic development in Lithuania, and the challenges it poses for policy makers.

\section{Emigration: General trends}

The Lithuanian population has always been characterised by high emigration rates. This was true during the pre-Soviet and Soviet periods, and it is true today.

According to data from the Statistics Lithuania (based on the 2011 census), over the past 22 years (1990-2011) 728700 people emigrated from Lithuania, the equivalent of approximately $20 \%$ of the Lithuanian population of 1990 s. In addition, population losses due to migration are accelerating: from $7.5 \%$ of the resident population (at the beginning of period) in 1990-2000 to $12.9 \%$ in 2001-11. Immigration remains low, and has only a symbolic compensatory effect. For the past decade Lithuania has had the highest negative net migration in the European Union. This situation, sometimes referred to by politicians as "evacuation", has unfortunately not been effectively contrasted.

High emigration rates, sometimes claimed in media debates to be part of the "Lithuanian genetic code", are the result not only of the current social economic situation, but also of past migration trends, and they reflect a migration culture formed over the past 20 years. A brief overview of past migration may thus contribute to a better understanding of current situations and problems.

\section{A brief overview of past migrations (1990-2008)}

Analysing the phenomenon of emigration from Lithuania over the past decades (Figures 3.1 and 3.2) it is possible to identify several stages ${ }^{1}$ in terms of migration flows, models, strategies, and the interrelation between migration and socio-economic development. 
Figure 3.1. International migration in Lithuania, 1980-2012

Thousands

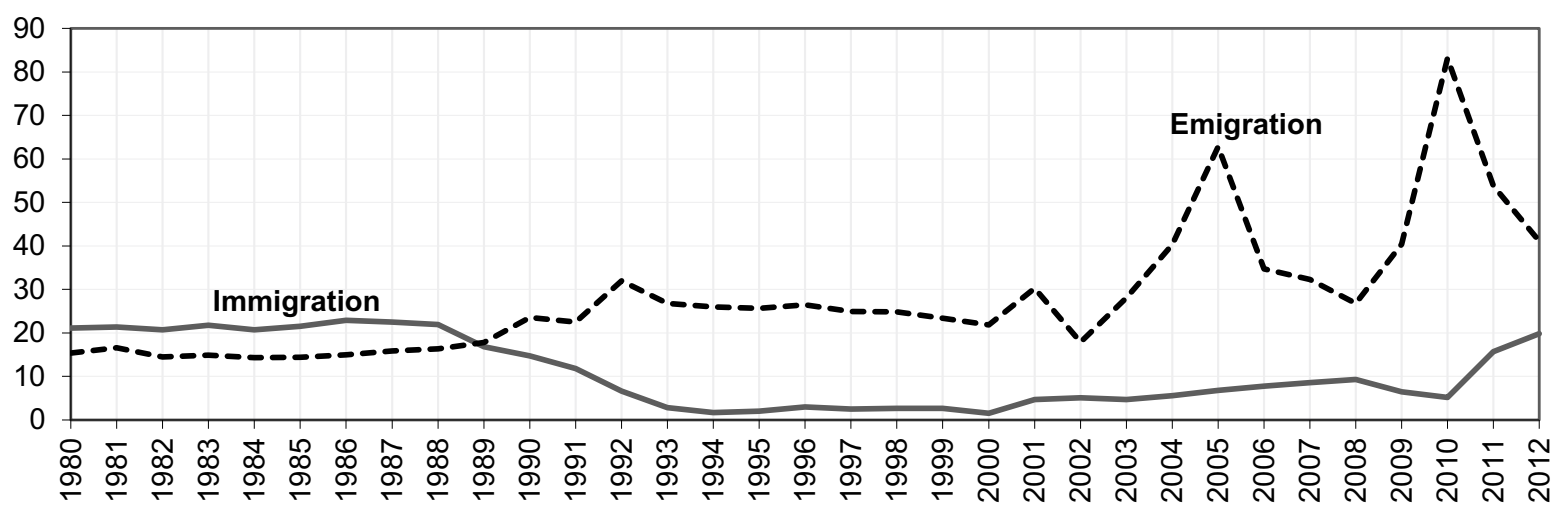

Source: Statistics Lithuania.

Figure 3.2. Registered and unregistered emigration from Lithuania, 1990-2012

Thousands

Unregistered emigrants

Registered emigrants

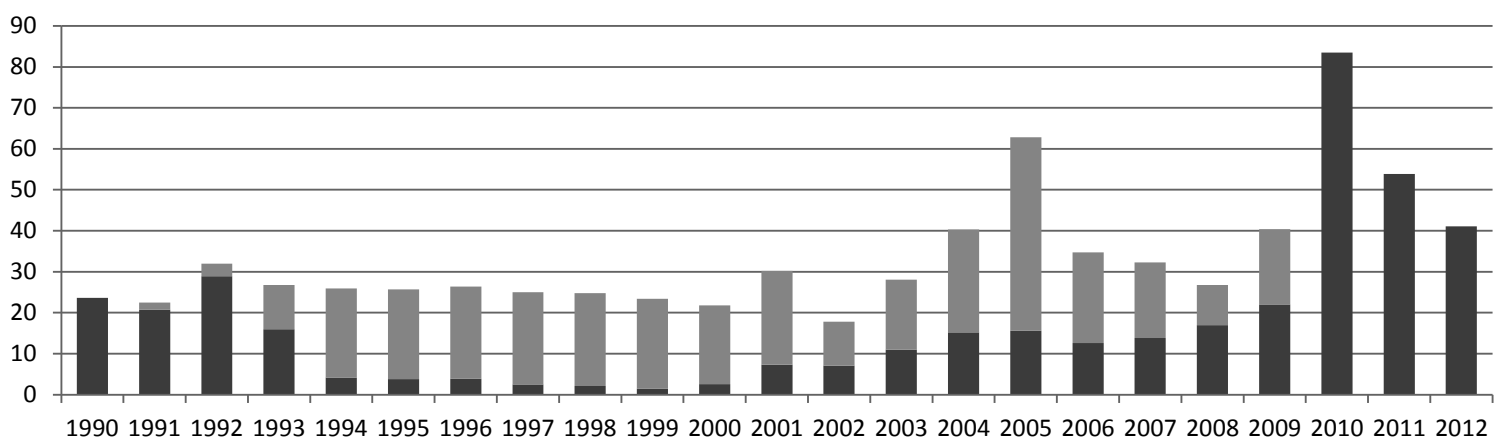

Note: For the years 1990-2000 current emigration statistics have been recalculated based on 2001 census results; for the years 2001-11, statistics have been recalculated based on 2011 census data.

Source: Statistics Lithuania.

\section{9/1990-1993: Repatriation, “de-Sovietisation” (free choice)}

The last decade of the $20^{\text {th }}$ century (1989/90-1993) witnessed an essential turn in migration trends: due to the opening of borders and other political developments, emigration replaced immigration. The emigration of that period can be divided into two main categories: return migration/repatriation Russians, Belarussians, the Ukrainians) and the realisation of emigration potential accumulated during the Soviet period, involving, for example, Jews leaving Lithuania and the first tentative signs of Lithuanian emigration to the West (Sipavičienè and Stankūnienè, 2011). Emigration during this period tended to be long-term/permanent, legal, and declared. 


\section{2/1993-2003: Emigration as an economic/survival strategy}

Since the beginning of the 1990s (1992-93), with the advancement of the market economy, new forms of migration emerged. A "petty trade" migration model first dominated, with short commercial cross-border visits to purchase and sell small volumes of merchandise. Migration turned westward, its geography expanded, long term migration gave way to different types of temporary or circular migration, and migration was often part of a business strategy. A stud carried out in 1993-96 (Sipavičiené, 1997; Frejka et al., 1998) indicated that during the period in question, the purpose of migration also started changing: from choice of residence to important economic (or even survival) strategy. Migrants went not to the closest countries, but to the countries where they could earn the most (e.g., through informal trading or employment) or where study was likely to provide the greatest return (Lietuva, 2004). In those years, over $80 \%$ of emigration was unregistered (Figure 3.2), and the scale of emigration remained high.

\section{Late 1990s-early 2000s: The gradual shift to labour migration}

"Commercial" or "petty trade" migration, which dominated the early 1990s, waned, and other forms of migration, such as labour migration, emerged. Research indicates only rare cases of migrants creating businesses in Lithuania with capital accumulated through working abroad. Labour migration, though still mainly unregistered and often employed in destination countries' "shadow economies", became better organised, frequently characterised by "chain migration" and operating through networks created by earlier migrants. Student migration - which in the early 1990s was mainly viewed as a way to obtain a visa and move abroad, sometimes for employment - gradually became de facto migration for study, an investment in the student's future. Brain drain remains intensive (Stankūnienè, 1996), though cases of direct "brain waste", when highly qualified scientists and specialists move for unqualified jobs, has diminished. Family reunification in destination countries has intensified, which marks the beginning of permanent migration (Sipavičienè, 2006).

Migration models established during this period largely determined further migration developments after Lithuania's accession to the European Union. In Lithuania, expectations were that many Lithuanians already working in EU countries would acquire legal status upon accession. While this did occur, the numbers were not as great as forecast, and the shift to legal labour migration still took time to occur.

\section{4-08: legalisation/freedom of choice}

European integration processes and the opening of EU labour markets heavily affected Lithuanian emigration, and in fact, EU countries are the most popular destinations during this period, with the United Kingdom and Ireland (the first to have opened their labour markets) as absolute leaders. The role of formal and informal migration networks increased (up to $80 \%$ of Lithuanian emigrants indicated that they found jobs abroad with the help of already established relatives, friends, etc.). These networks sometimes engaged in direct recruitment or even criminal activity - trafficking in human beings. Although the main causes of migration remained economic (Table 3.1), non-economic reasons such as "professional ambitions", self-realisation, "adventure", studies etc. became increasingly important, especially among young migrants. 
Table 3.1. Unregistered emigrants, reason for departure, 2001-07

\begin{tabular}{lrrrrrr}
\hline & $2001-02$ & 2003 & 2004 & 2005 & 2006 & 2007 \\
\hline Job contract & 60.8 & 82.1 & 79.8 & 81.8 & 63.2 & 69.3 \\
Studies & 3.9 & 4.3 & 4 & 4.3 & 6.6 & 12.6 \\
Family circumstances & 17.2 & 11.1 & 4.6 & 8.9 & 13.8 & 7.9 \\
Other & 18.1 & 2.6 & 11.6 & 4.9 & 16.4 & 10.2 \\
Total & 100 & 100 & 100 & 100 & 100 & 100 \\
Total (thousands) & 23.2 & 11.7 & 17.3 & 32.5 & 15.2 & 12.7 \\
\hline
\end{tabular}

Source: Statistics Lithuania.

Despite changed circumstances and contrary to broadly held expectations in Lithuania, a significant part of emigration remained unregistered. However, this was less related to immigration restrictions at the destination (as in the previous decade) than to other factors, such as a demand for cheap labour in the shadow economy, unrealistic expectations when emigrating (moving abroad for immediate economic benefit and staying on after failing to "fulfil the plan"), an attempt to retain social benefits or health insurance in Lithuania, etc. (Maslauskaitė and Stankūnienè, 2007).

Emigration declined after 2005, while return migration, albeit almost symbolic, rose.

\section{The economic crisis and migration (2009-12)}

\section{Survival strategy once again?}

Unfortunately, those positive developments stopped with the outbreak of the economic crisis, which initiated a new unprecedented wave of emigration, turning migration once again from an expression of "free choice/freedom of movement" to a desperate search for economic opportunities abroad and a "survival strategy". In 2010 there was an unprecedented peak -83500 Lithuanian inhabitants registered their departure from Lithuania. Such a significant increase in the number of registered emigrants is in all likelihood attributable mainly to the introduction of a statutory duty for all permanent residents of the country to pay compulsory health insurance, a circumstance which may well have also encouraged emigrants who had failed to register their departure from Lithuania earlier, to do so now. Nevertheless, 2011 and 2012 witness continuous high emigration outflows, which may prove to reflect a new, real wave of emigration (rather than an artefact due to improved reporting, as had unrealistically been hoped).

In the absence of in-depth research, it is difficult to establish the determinants of emigration with any certainty. A preliminary analysis of changes in economic development and emigration indicators, however, show an evident correlation between emigration trends and unemployment, and between net migration and GDP dynamics (Figure 3.3). The younger generations in general - and those entering the labour market for the first time in particular - were hit hardest by the economic recession. The level of unemployment among young Lithuanians surpassed 30\% (Figure 3.4). 
Figure 3.3. Migration and economic indicators in Lithuania, 2000-10

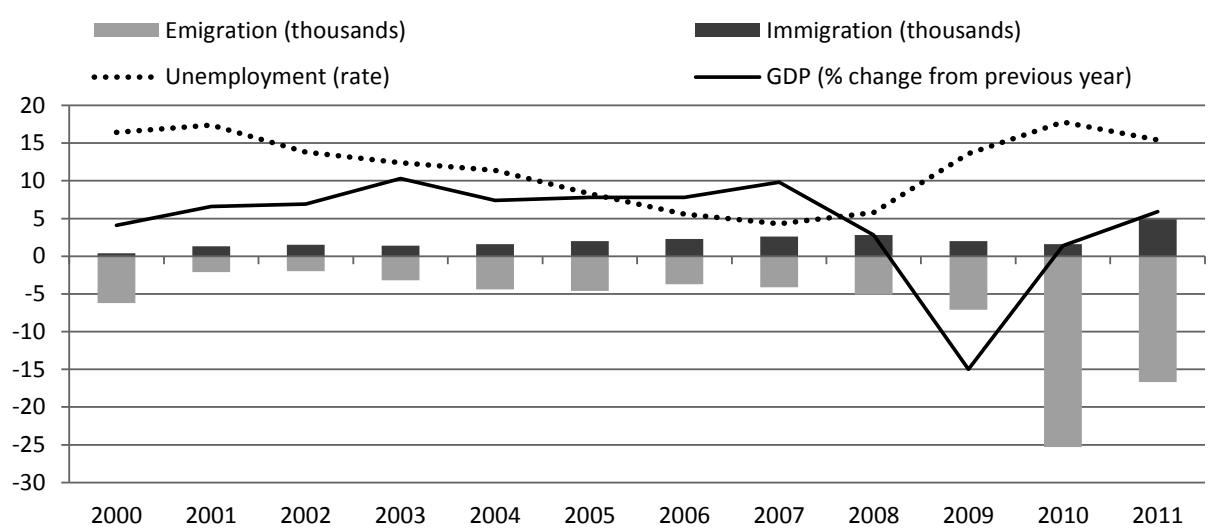

Source: Statistics Lithuania.

Figure 3.4. Total unemployment and youth unemployment, 2005-11

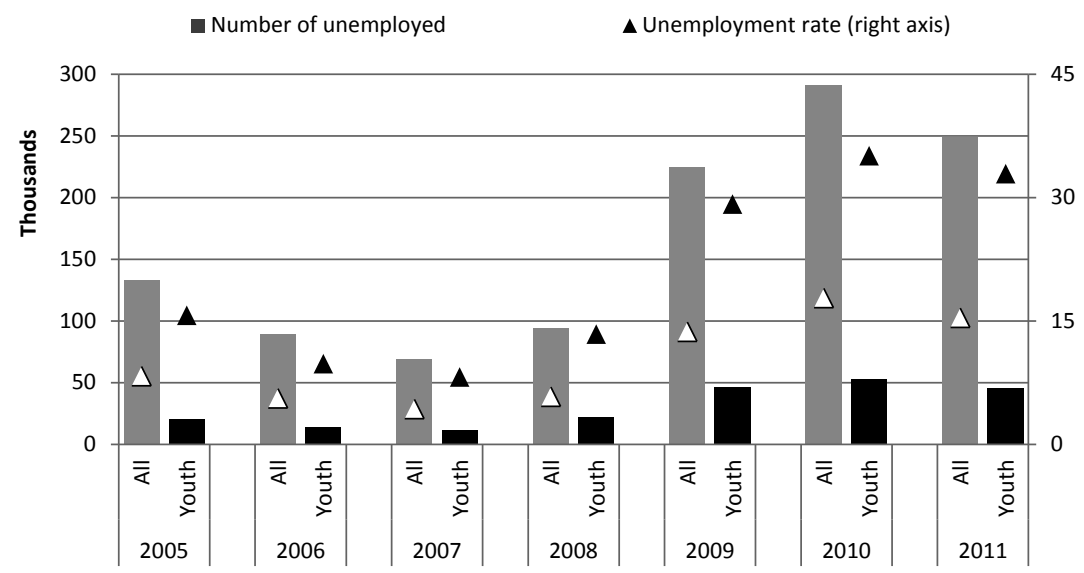

Source: Statistics Lithuania.

Better employment opportunities, higher salaries (three to four times higher, even when purchasing power is taken into account) and better social security benefits, etc., are major economic reasons for Lithuanians to move abroad. In the context of the crisis, in addition to macro-economic factors, new push factors emerged at the micro-economic level, such as the inability to pay back bank loans and other financial commitments (even with a job in Lithuania), mass bankruptcy of small and medium businesses, etc. In many cases, emigration became the only economic survival strategy (Stankūnienè et al., 2012). New phenomena, such as moving abroad due to "personal bankruptcy" (a very complicated procedure in Lithuania) have been documented. The above push factors, coupled with frustration and disillusion with government economic policy, imbue emigration with the features of desertion.

In addition to economics, other reasons, such as social insecurity, social injustice ("social serfdom") or family-related reasons (e.g., family reunion) contribute to increasing emigration flows (Sipavičienè and Stankūnienè, 2011). 
On the other hand, factors related to past migrations, such as the existence of wellfunctioning informal migration networks as well as established support mechanisms at the destination can be identified. These act as pull factors that facilitate the realisation of migration intentions. Two recent studies commissioned by the IOM Vilnius office and carried out in Lithuania (2008 and 2010) reveal that the Lithuanian migration network in destination countries is quite extensive $-30 \%$ of Lithuanian residents have someone from their family/household working/studying/living abroad and $80 \%$ have migrants in their close social environment (friends, relatives, etc.) (Sipavičienè, 2011). An effective migrant support mechanism exists, as can be deduced from the fact that as many as $80 \%$ of emigrants find a job abroad through this channel.

\section{Return migration, chain migration and changes in the geography of emigration}

As the economic crisis spread globally to encompass most destination countries for Lithuanian migrants, return migration was expected to increase. This is because, as a rule, migrants are the first to be fired, especially temporary, seasonal workers in sectors such as construction, manufacturing and tourism. No pronounced increase in return migration was observed, however. On the contrary, the first years of crisis witnessed a decrease in return migration from 6300 people in 2008 to only 4200 people in 2010 (Figure 3.5). The increase in return migration recorded in 2011 should be evaluated with caution, for, rather than real returns, the datum could reflect mere formal return declarations by emigrants seeking to (once again) benefit from the Lithuanian health care system. Only targeted research, or an analysis of emigration data collected over the course of several years, will be able to reveal whether emigrants are indeed returning to Lithuania.

Figure 3.5. Immigration (foreigners) and return migration (Lithuanian nationals), 2001-11

Thousands

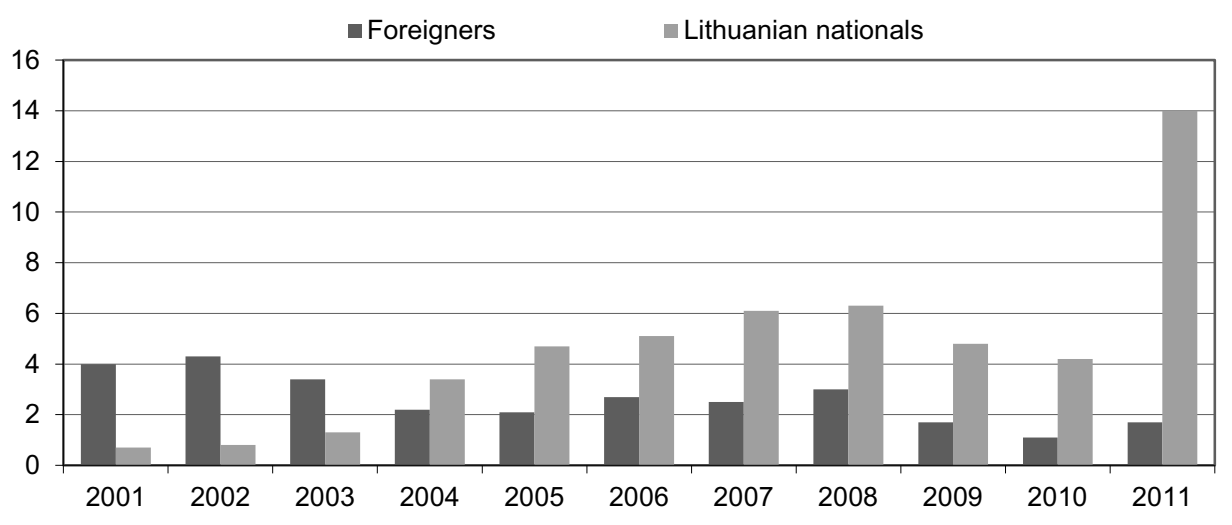

Source: Statistics Lithuania.

As data from some destination countries show, emigrants who lose their jobs, rather than opt for return migration, often choose to remain in the destination country (especially if they are entitled to social benefits) or to migrate to a third country (OECD, 2011). The evaluation of chain migration is rather complicated. Here, too, only scientific studies will be able to assess how widespread this phenomenon is. However, the crisis affects also migrant choice of initial emigration destination, to favour closer, economically more secure and "reliable" countries. Statistical data indicate that, in 2011, 
an absolute majority (94.4\%) of Lithuanian emigration was intra-continental, of which $81.8 \%$ was within the European Union (Table 3.2).

Among destination countries, the leaders remain the United Kingdom (49\%) and Ireland $(10.4 \%)$, though the importance of Ireland continues to diminish. At the same time, new trends can be identified - increased emigration to Scandinavian countries (that are less affected by the economic crisis, that have a better labour market situation, and better social security systems, even for the unemployed). An especially pronounced increase was observed in emigration to Norway. Compared with the pre-crisis period (2008), emigration flows from Lithuania to Norway in 2011 increased more than tenfold (Table 3.2), comprising $7.4 \%$ of Lithuania's total emigration (from only $2 \%$ in 2008 ). On the other hand, the proportion of the Russian Federation, Belarus, and Ukraine in the emigration outflow structure has significantly decreased (from $16.5 \%$ in 2008 to only $4.4 \%$ in 2011); the importance of the United States as a destination country has also decreased (from $10.5 \%$ to $3.3 \%$ during the same period).

Table 3.2. Registered Lithuanian emigrants, by country of destination

\begin{tabular}{|c|c|c|c|c|c|}
\hline \multicolumn{6}{|c|}{ Share } \\
\hline Country of destination & 2005 & 2008 & 2009 & 2010 & 2011 \\
\hline Europe & 83.2 & 83.5 & 86.4 & 95 & 94.4 \\
\hline EU27, of which: & 67.5 & 63.3 & 61.5 & 83.6 & 81.8 \\
\hline Ireland & 13.3 & 11.7 & 12.6 & 15.7 & 10.4 \\
\hline Spain & 5.1 & 5.4 & 6.2 & 4.3 & 3.6 \\
\hline United Kingdom & 27.1 & 26.3 & 26 & 49.2 & 49 \\
\hline Germany & 9.5 & 7.9 & 6.1 & 4.6 & 7 \\
\hline Other European countries & 15.7 & 20.2 & 24.9 & 11.3 & 12.6 \\
\hline Belarus & 4.5 & 5.9 & 9.4 & 1.7 & 1.6 \\
\hline Norway & 1.5 & 2 & 2.4 & 5.9 & 7.1 \\
\hline Russian Federation & 7.1 & 6.3 & 5.2 & 1.8 & 2 \\
\hline Ukraine & 1.8 & 4.3 & 4.6 & 0.8 & 0.8 \\
\hline Africa & 0.2 & 0.2 & 0.3 & 0.1 & 0.2 \\
\hline America & 13.9 & 12 & 8.7 & 3.7 & 3.9 \\
\hline United States & 12.9 & 10.5 & 7.7 & 3.3 & 3.3 \\
\hline Asia & 2.4 & 4.1 & 4.3 & 0.9 & 1.2 \\
\hline Oceania & 0.3 & 0.2 & 0.3 & 0.1 & 0.3 \\
\hline Not indicated & 0 & - & 0 & 0 & 0 \\
\hline Total & 100 & 100 & 100 & 100 & 100 \\
\hline Total (absolute value) & 15571 & 17015 & 21970 & 83157 & 53863 \\
\hline
\end{tabular}

Source: Statistics Lithuania.

The full opening of labour markets in Germany and Austria in 2011 did not have any pronounced impact on the geography of emigration from Lithuania. This full opening, however, simplified migration procedures for skilled workers, expanded recruitment and improved information for aspirant migrants, which could easily have led to an increased share of skilled workers among migrants. Although not yet backed by hard data, such a development arouses concern in Lithuania. Fears are related to the possible loss of skilled workers such as medical doctors and other health care personnel, IT specialists or engineers. 


\section{The changing composition of emigration flows}

The economic crisis not only increased the scale of emigration, but also affected its composition. First, an increase has been documented, in the emigration of people of working age, especially of young people (Table 3.3, Figure 3.6). In 2011, young persons aged 20-34 made up more than half (55.4\%) of all Lithuanian emigrants (compared with $46.6 \%$ in 2008).

Table 3.3. Distribution of Lithuanian emigrants by age, 2007-12

Percentage

\begin{tabular}{lrrrrrr}
\hline Age & 2007 & 2008 & 2009 & 2010 & 2011 & 2012 \\
\hline $0-14$ & 13.9 & 13.7 & 12.1 & 10.2 & 10.5 & 12.6 \\
$15-19$ & 9.8 & 7.0 & 6.0 & 5.9 & 7.1 & 7.1 \\
$20-34$ & 43.3 & 47.4 & 48.4 & 54.9 & 55.4 & 52.9 \\
$35-39$ & 8.8 & 9.4 & 10.3 & 9.4 & 8.6 & 8.8 \\
$40-59$ & 20.9 & 19.4 & 20.7 & 18.7 & 17.1 & 16.8 \\
$60+$ & 3.3 & 3.1 & 2.5 & 0.9 & 1.3 & 1.9 \\
Total & 100 & 100 & 100 & 100 & 100 & 100 \\
\hline
\end{tabular}

Source: Statistics Lithuania.

Figure 3.6. Age-sex pyramid of Lithuanian emigrants, 2007 and 2011

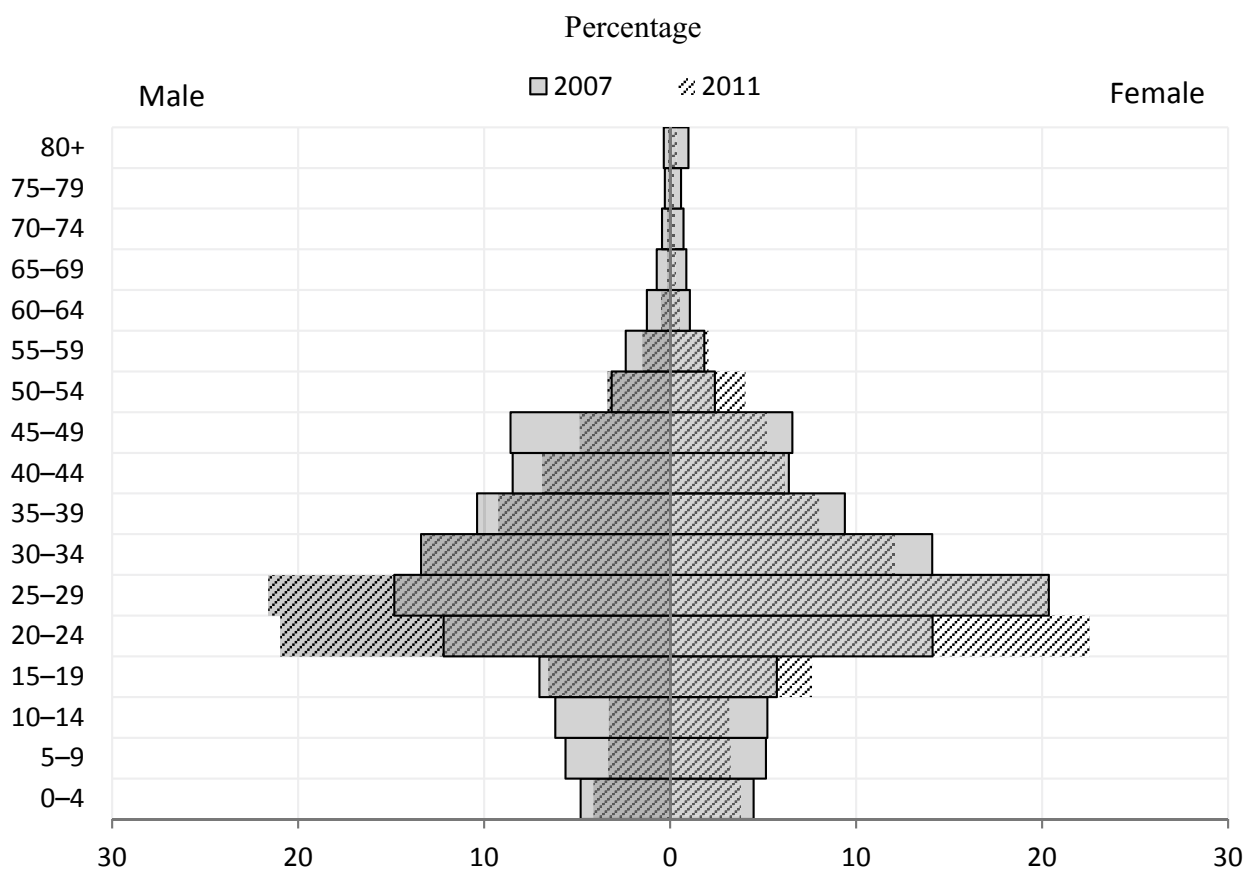

Source: Statistics Lithuania (2012), Demografijos metraštis 2011, Vilnius.

Migration losses that mainly involve young people are known to affect future demographic processes (population ageing, increased dependency ratio, future family formation, fertility, etc.) as well as future labour resources, which may then have to be imported from other countries. The emigration of young people reinforces brain drain, 
i.e. the loss of highly qualified labour force, which may in turn lead to decreasing economic and competitive potential. No data on the emigrants' level of education are available, however, and no studies on possible brain drain have been conducted in recent years.

The low proportion of children among emigrants is also evident. Increasingly, emigrants depart without their children, leaving them to the care of relatives or even strangers; sometimes children are left without any guardians at all. According to data from the State Child Rights Protection and Adoption Service, the number of children left in foster care by migrant parents has more than doubled since the pre-crisis period (from 916 in 2007 to 2134 in 2011; Table 3.4). These are only official data however. More frequently migrants, hoping that emigration will be temporary, fail to arrange for foster care and leave children without any adult guardian. The consequences of this phenomenon for families and children has been studied (Maslauskaite and Stankūnienè, 2007), but its broader effects on future demographic, social and economic development is difficult to forecast.

Table 3.4. Parental requests for foster care for children due to parents' emigration, 2007-10

Annual number of new requests by child's age

\begin{tabular}{|c|c|c|c|c|c|c|}
\hline & & 2007 & 2008 & 2009 & 2010 & 2011 \\
\hline \multirow{5}{*}{$\begin{array}{l}\text { Age of } \\
\text { child }\end{array}$} & $0-3$ & 99 & 131 & 148 & 144 & 132 \\
\hline & $4-6$ & 171 & 275 & 287 & 290 & 326 \\
\hline & $7-9$ & 164 & 354 & 373 & 386 & 392 \\
\hline & $10-14$ & 295 & 674 & 694 & 676 & 721 \\
\hline & $15-17$ & 187 & 518 & 517 & 530 & 563 \\
\hline \multicolumn{2}{|l|}{ Total } & 916 & 1952 & 2019 & 2026 & 2134 \\
\hline
\end{tabular}

Source: State Child Rights Protection and Adoption Service.

Family separation due to migration represents a serious problem in Lithuania, but official statistics do not register an increase in this phenomenon. On the contrary, a decline in the proportion of married people among emigrants can be observed - their share decreased from $56 \%$ in 2001 to $30.4 \%$ in 2011 (Table 3.5 ).

Table 3.5. Distribution of registered Lithuanian emigrants aged 18 and older, by marital status, 2001-11

Percentage

\begin{tabular}{lrrrrrr}
\hline Marital status & $\mathbf{2 0 0 1}$ & $\mathbf{2 0 0 7}$ & $\mathbf{2 0 0 8}$ & $\mathbf{2 0 0 9}$ & $\mathbf{2 0 1 0}$ & $\mathbf{2 0 1 1}$ \\
\hline Single & 29.9 & 38.4 & 43.1 & 42.4 & 50.8 & 55.6 \\
Married & 56 & 44 & 39.9 & 42 & 34.7 & 30.3 \\
Divorced & 8 & 15.3 & 15.1 & 13.8 & 13.3 & 12.8 \\
Widowed & 4.7 & 2.4 & 1.9 & 1.8 & 1.2 & 1.3 \\
Not indicated & 1.4 & - & - & - & - & - \\
\hline Total (absolute value) & $\mathbf{5 9 9 0}$ & $\mathbf{1 1 2 1 8}$ & $\mathbf{1 4 0 9 0}$ & $\mathbf{1 8 ~ 7 8 8}$ & $\mathbf{7 3 \mathbf { 1 8 5 }}$ & $\mathbf{4 7 3 2 9}$ \\
\hline
\end{tabular}

Source: Statistics Lithuania.

\section{Economic activity}

Statistics Lithuania data on emigrants by previous employment show, that even during the economic boom, in 2008, approximately $56 \%$ of all emigrants were 
unemployed prior to departure. The economic crisis appears to have increased their share in the population of emigrants to $82 \%$ in 2011 (Table 3.6). As these figures are based on declared emigration, they do not indicate whether long-term unemployed emigrants had been out of work for more than a year before departure or before the declaration of emigration, since in many cases, the date of declaration was subsequent to that of emigration, often by months or even years.

The majority of employed emigrants had been working in the wholesale and retail trade sectors $(4.6 \%)$, in manufacturing $(3.1 \%)$, transport $(1.9 \%)$, in the hotel/restaurant sector $(1.6 \%)$, and in construction $(1.8 \%)$ (Table 3.6). These are all sectors in which Lithuania itself had experienced labour shortages before 2008. Despite the crisis and dramatically increased unemployment, some sectors in Lithuania are unable to fill positions for certain categories of workers (scientists, engineers, medical staff, IT, etc., but also construction, transport). This type of situation - when labour shortages and emigration coincide - can be attributed to both economic (e.g. wage differentials), and non-economic (e.g., self-realisation) factors. Such conditions are expected to persist in the near future, suggesting that highly skilled workers will continue to emigrate in large numbers.

Table 3.6. Distribution of registered Lithuanian migrants aged 15 and older, by previous employment, 2008-11

Percentage

\begin{tabular}{|c|c|c|c|c|}
\hline Year & 2008 & 2009 & 2010 & 2011 \\
\hline Out of employment for at least one year & 56.0 & 81.3 & 85.0 & 81.8 \\
\hline Employed & 44 & 18.7 & 15.0 & 18.2 \\
\hline Agriculture & 0.6 & 0.2 & 0.2 & 0.3 \\
\hline Mining and quarrying & 0 & 0 & 0 & 0 \\
\hline Manufacturing & 9.3 & 2.4 & 2.3 & 3.1 \\
\hline Electricity, gas and water supply & 0.2 & 0.1 & 0.1 & 0.2 \\
\hline Construction & 5.1 & 2 & 1.5 & 1.8 \\
\hline $\begin{array}{l}\text { Wholesale and retail trade; repair of motor vehicles, } \\
\text { motorcycles and personal and household goods }\end{array}$ & 9.7 & 2.4 & 3.7 & 4.6 \\
\hline Hotels and restaurants & 3.5 & 1.1 & 1.1 & 1.6 \\
\hline Transport, storage and communication & 4.7 & 7.3 & 1.6 & 1.9 \\
\hline Financial intermediation & 0.5 & 0.1 & 0.2 & 0.2 \\
\hline Real estate & 4.2 & 0.2 & 0.2 & 0.2 \\
\hline Public administration & 1.2 & 0.3 & 0.3 & 0.4 \\
\hline Education & 2.1 & 0.5 & 0.6 & 0.7 \\
\hline Health and social work & 1.3 & 0.2 & 0.4 & 0.5 \\
\hline Other activities & 1.6 & 1.9 & 0.0 & 0.0 \\
\hline Total & 100.0 & 100.0 & 100.0 & 100.0 \\
\hline Total (absolute numbers) & 14618 & 19357 & 74674 & 48212 \\
\hline
\end{tabular}

Source: Statistics Lithuania.

Emigration of secondary school graduates is on the rise, and a large proportion of longterm unemployed emigrants are young people who, having graduated from schools and universities, were unable to find jobs in Lithuania. The highest rates of unemployment are among youth, as are the highest rates of emigration. An inadequate match between high school curricula and the needs of the Lithuanian labour market acts as a push factor 
contributing to brain drain, especially among young people. An additional contributing factor is the recent (2008-09) rise in university tuition fees in Lithuania, making studies abroad - especially in more prestigious foreign universities - relatively cheaper and more attractive.

\section{Emigration potential}

Still, the biggest concern in Lithuania stems from the fact that, mostly due to the economic crisis, emigration potential - as reflected in emigration intentions - is increasing rather than diminishing. A number of studies and public opinion poll surveys indicate that nearly half of the Lithuanian adult population is considering emigration and would like to move abroad for employment (48.4\% in 2012, compared with $37 \%$ in 2011 , 29\% in 2010 and 23\% in 2008) (Apklausa, 2011; Apklausa, 2012; Požiūris, 2008; Sipavičienė et al., 2011). Migration intentions among young adults have taken on unprecedented dimensions, reaching almost 60\% among people under 30 (Sipavičienè et al., 2011). These tendencies have been accelerating since the onset of the crisis and represent a real threat to Lithuania's future (Figure 3.7).

Figure 3.7. Willingness of Lithuanians to move abroad for work, by age group

Percentage

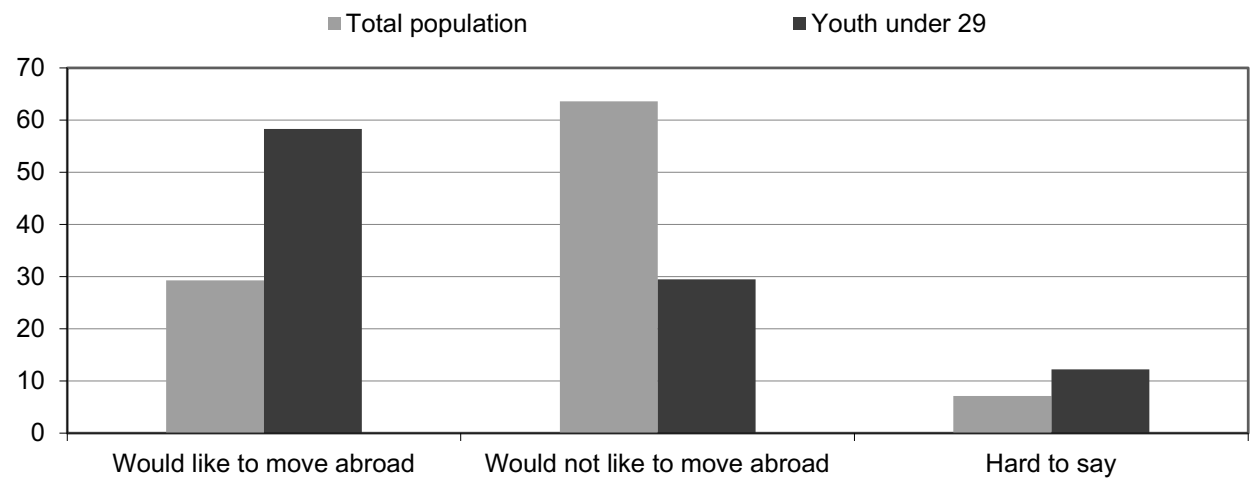

Source: IOM Study, 2008 and 2010 Public Opinion Surveys.

\section{Social and economic impact}

The first and most obvious consequence of mass emigration is a decreasing population. Mass emigration, coupled with very limited immigration and return migration, reduced the Lithuanian population by nearly one sixth over two decades, from 3.7 million residents in 1990 to 3 million in 2011 . While natural increase fully or partially compensated for migration losses prior to 1994, since 1995 the population has been decreasing. In the years of economic crisis (2009-11), emigration accounted for approximately $90 \%$ of total population decline. While depopulation is the aspect most often emphasized by politicians and the media when discussing emigration, changes in population composition due to emigration may be even more problematic. The skewed distribution of outflows towards the younger age-groups (Figure 3.8), and the mirrorimage age composition of the remaining population, increase the dependency ratio and the burden on the active population, indirectly acting as an additional push factor. In addition, the real wage index continues to decrease (Table 3.7). 
Figure 3.8. Age distribution of emigrants and residents, 2010

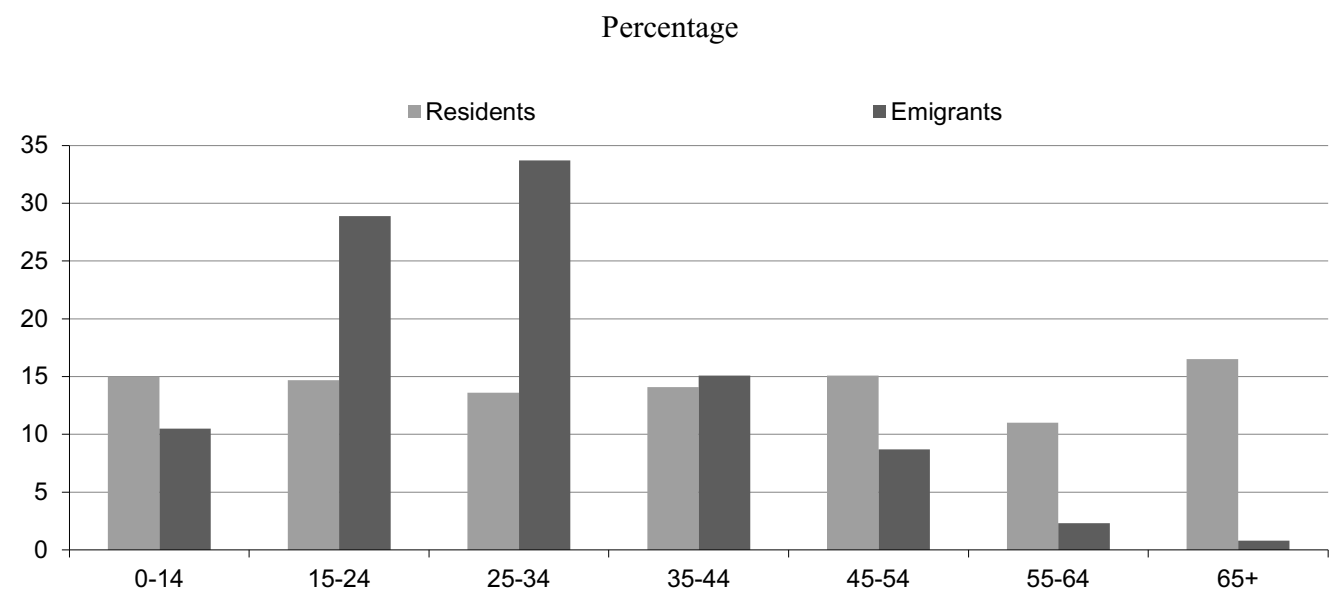

Source: Statistics Lithuania.

Table 3.7. Real wage index in Lithuania, 2005-11

Percentage change compared to previous year

\begin{tabular}{ccccccc}
\hline $\mathbf{2 0 0 5}$ & $\mathbf{2 0 0 6}$ & $\mathbf{2 0 0 7}$ & $\mathbf{2 0 0 8}$ & $\mathbf{2 0 0 9}$ & $\mathbf{2 0 1 0}$ & $\mathbf{2 0 1 1}$ \\
\hline 106.8 & 114.9 & 117.0 & 110.1 & 92.8 & 95.7 & 98.5 \\
\hline
\end{tabular}

Source: Statistics Lithuania.

The economic impact of emigration is not easy to evaluate on the basis of standard statistical data. A simple comparison of economic development and emigration indicators sometimes reveals paradoxical situations, raising more questions than it answers.

First, such intense emigration clearly predominated by people of working age would be expected to correspond to shrinking labour force indicators. Still, as can be seen from the statistical data (Table 3.8), this was not the case. During the years 2007-09 the labour force was growing. This was a temporary phenomenon, mainly due to an exceptionally large cohort entering the labour market (the cohort born in 1989-91, when due to political reasons, birth rates increased dramatically). The labour force began shrinking in 2010, and is expected to exhibit further and more drastic drops due both to smaller age-cohorts entering the labour force and emigration, potentially causing serious labour supply shortages should the economy recover.

Table 3.8. Labour force, employment and unemployment in Lithuania, 2004-11

\begin{tabular}{lrrrrrrr}
\hline & $\mathbf{2 0 0 4}$ & $\mathbf{2 0 0 5}$ & $\mathbf{2 0 0 6}$ & $\mathbf{2 0 0 7}$ & $\mathbf{2 0 0 8}$ & $\mathbf{2 0 0 9}$ & $\mathbf{2 0 1 0}$ \\
\hline Activity rate (\%) & 57.1 & 56.6 & 55.9 & 56.3 & 56.7 & 57.7 & 58.1 \\
Population aged 15+(thousands) & 2837.1 & 2840.2 & 2842.9 & 2846.8 & 2849.4 & 2844.9 & 2814 \\
Labour force (thousands) & 1620.6 & 1606.8 & 1588.3 & 1603.1 & 1614.3 & 1640.9 & 1634.8 \\
Employed (thousands) & 1436.3 & 1473.9 & 1499 & 1534.2 & 1520 & 1415.9 & 1343.7 \\
Unemployed (thousands) & 184.4 & 132.9 & 89.3 & 69.0 & 94.3 & 225.1 & 291.1 \\
Unemployment (\%) & 11.4 & 8.3 & 5.6 & 4.3 & 5.8 & 13.7 & 17.8 \\
\hline
\end{tabular}

Source: Statistics Lithuania. 
Another apparent paradox: even though more than $80 \%$ of adult emigrants are longterm unemployed, the number of unemployed people in Lithuania, as well as unemployment rates, steadily increased between 2007 and 2010. The prevailing explanation is that without emigration unemployment would have been much higher and social tensions greater. In fact, emigrants tend to be resourceful people, able and willing to work, who shun social benefits. Even if their departure helped to reduce unemployment, the country lost an important segment of the labour force. As noted above, the fact that the composition of the emigrant population by sectors echoes the labour shortage list, might lead to labour market imbalances when the economy starts to recover. Furthermore, if - in the context of persisting high emigration rates - immigration policy remains restrictive, the Lithuanian labour market will also face general labour shortages, which are likely to slow down economic recovery (Maldeikienè, 2009). Finally, emigration does not appear to have reduced pressure on the social welfare system (Gruževskis, Zabarauskaite, 2012). Statistical data indicate that, since 2007, both the number of beneficiaries and the sums paid on welfare have been on the rise (Table 3.9).

Table 3.9. Social welfare in Lithuania, 2005-11

\begin{tabular}{lrrrrrrr}
\hline & $\mathbf{2 0 0 5}$ & $\mathbf{2 0 0 6}$ & $\mathbf{2 0 0 7}$ & $\mathbf{2 0 0 8}$ & $\mathbf{2 0 0 9}$ & $\mathbf{2 0 1 0}$ & $\mathbf{2 0 1 1}$ \\
\hline Number of recipients & 54145 & 37849 & 36621 & 37292 & 73512 & 181285 & 221060 \\
Expenditures (thousands LTL) & 52822 & 43800 & 52135 & 78927 & 190660 & 510586 & n.a. \\
\hline
\end{tabular}

Source: Statistics Lithuania.

Conceivably, the loss of a very active and labour/business oriented segment of the labour force, even under conditions of unemployment, could result in missed opportunities and jobs not created, leading to increased unemployment and pressure on the social system. These are only speculations, however. Research is needed to elucidate the mechanisms by which emigration affects the Lithuanian economy.

Official emigration statistics do not register the level of education or professional qualifications of migrants, but several studies indicate that emigration of low-skilled people has been particularly high (Sipavičienė and Jeršovas, 2010; Karpavicius, 2006). Emigration could thus be among the factors contributing to the reduction in the share of unskilled workers, and the consequent rise in the share of highly skilled workers, registered in the Lithuanian labour force since 2004 (Figure 3.9).

The result is that low-skilled workers are disproportionately in demand, and before the crisis these workers saw greater relative wage increases than those seen by highly skilled workers. This in turn served as an additional push factor for highly qualified specialists. In this way, imbalances in the wage system created by migration act as a catalyst for further emigration (Maldeikienè, 2010).

On the other hand, wages have not kept pace with general work productivity (Table 3.10), creating imbalances in the economy (Maldeikiene, 2010). During the economic boom wages were rising faster than productivity, and the opposite occurred during the crisis. . Emigration reacts not only to changes in economic growth per se, but also to internal economic imbalances, and as such is difficult to predict. 
Figure 3.9. Labour force composition by skill level, 2004-11

Percentage

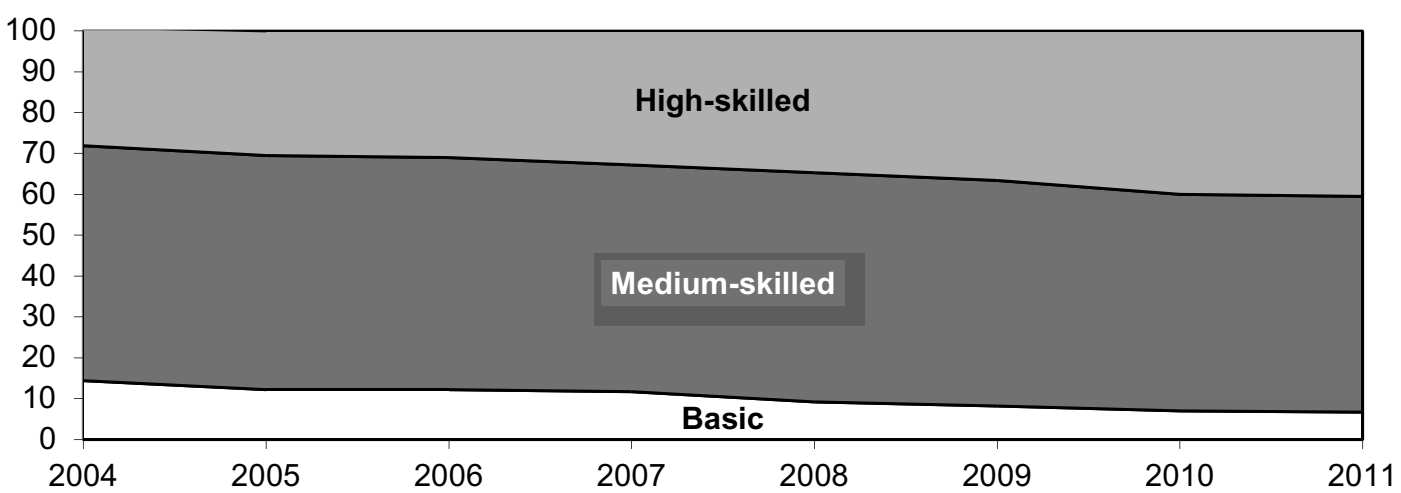

Source: Statistics Lithuania.

Table 3.10. Productivity and wage development, 2006-11

\begin{tabular}{lrrrrrr}
\hline & $\mathbf{2 0 0 6}$ & $\mathbf{2 0 0 7}$ & $\mathbf{2 0 0 8}$ & $\mathbf{2 0 0 9}$ & $\mathbf{2 0 1 0}$ & $\mathbf{2 0 1 1}$ \\
\hline Work productivity (value added for one hour worked, LTL) & 27.2 & 31 & 34.7 & 31.5 & 33.9 & 37.6 \\
Percentage change from previous year & 12.9 & 13.9 & 11.9 & -9.2 & 7.6 & 10.9 \\
Average monthly wage (LTL) & 1496 & 1802 & 2152 & 2056 & 1988 & 2046 \\
Percentage change from previous year & 17.2 & 20.5 & 19.3 & -4.4 & -3.3 & 2.9 \\
\hline
\end{tabular}

LTL: Lithuanian litas.

Source: Statistics Lithuania.

Remittances are a potentially positive aspect of emigration. As can be seen in Figure 3.10, remittances rebounded from a drop in 2009, and in 2011 constituted LTL 4.84 billion, equivalent to $4.6 \%$ of GDP or approximately $25 \%$ of all salaries paid in Lithuania. The importance of remittances to families and households, especially during the crisis, has been enormous - it cushioned the consequences of the economic crisis, and in many cases compensated for financial problems due to drastically reduced incomes in Lithuania. No in-depth research regarding the use of remittances has been carried out in Lithuania, but the experience of other countries suggests that the money is often squandered, and only an insignificant part is used for investments, business or job creation. Thus, remittances, albeit very important for family consumption, have probably had a much smaller impact on the country's economy.

Other positive effects - e.g. expertise acquired abroad, joint projects/ventures, etc. could not be evaluated due to the small numbers of return migrants, and the lack of studies and relevant statistical information. 
Figure 3.10. Remittances in millions of litas and as a proportion of GDP

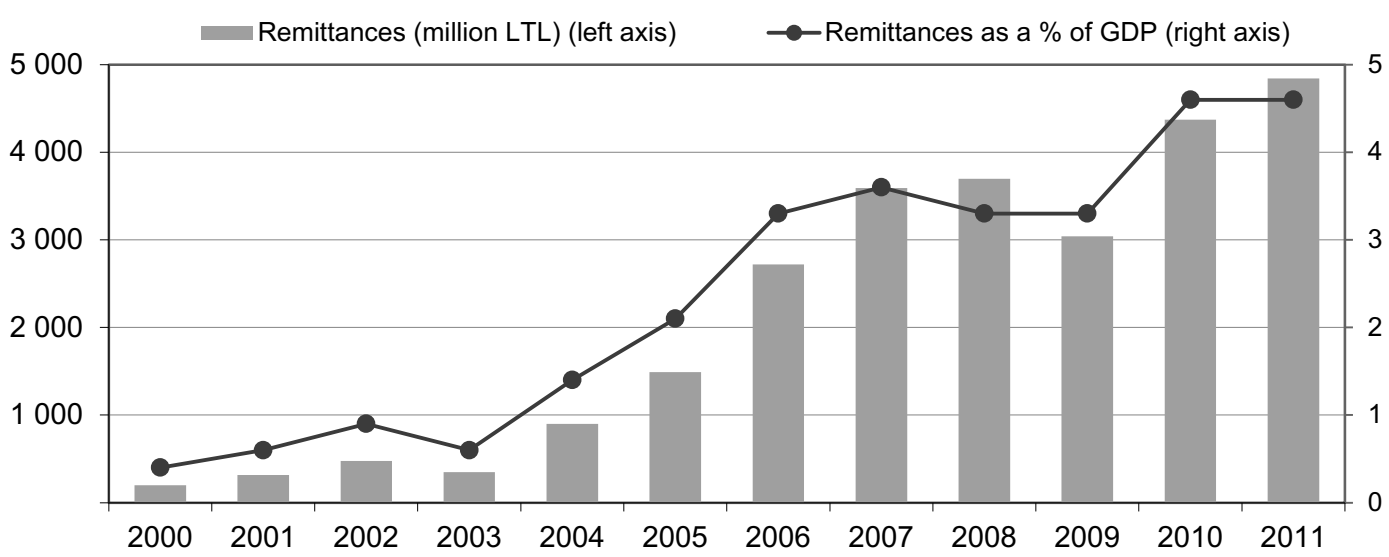

Source: Central Bank of the Republic of Lithuania; Statistics Lithuania.

\section{Policy response}

Lithuania's policies regarding migration, asylum and other issues related to the movement of people are not concentrated in any single document. Nonetheless, migration policy provisions contained in separate documents show that the return of Lithuanian citizens to Lithuania is considered a very important goal (IOM/EMN, 2012), and the immigration of third-country nationals ${ }^{2}$ is merely seen as an additional means of solving the economic problems of the country. Among such political and strategic documents, the following are worthy of mention:

- Long-Term Development Strategy of the State ${ }^{3}$ which only mentions the problems linked to emigration, but does not envision measures to tackle them.

- $\quad$ National Demographic (Population) Policy Strategy ${ }^{4}$ stipulates the strategic goal of economic migration policy - to ensure that, in case of fast economic growth, Lithuania would not experience labour shortages and would avoid the negative consequences of migration.

- Economic Migration Regulation Strategy ${ }^{5}$ (adopted April 2007) identifies two goals - to meet the needs of the Lithuanian labour market and to encourage the return of economic migrants to their respective countries of origin. Workers from third countries must be attracted only in sectors facing labour shortages, where workforce from Lithuania or other EU member states cannot be engaged, and only for a limited duration. Among other goals, reaching zero net migration by 2012 was envisioned. Due to the economic crisis, by 2010 almost all activities under the strategy had been terminated.

- $\quad$ Lithuania's Immigration Policy Guidelines ${ }^{6}$ (adopted December 2008) - the first and only political document presenting the position of the state on migration, including the immigration of third-country nationals. The Guidelines stipulate the following goals for the country's immigration policy: i) to ensure that Lithuania does not experience labour shortages or other detrimental effects of emigration, such as an ageing population; ii) to ensure the effective management of immigration flows; iii) to participate, in an active and targeted manner, in the formulation of EU immigration policy. 
- The document clearly affirms that the guiding principle for the immigration of aliens must be the benefit of the state, whereas meeting the needs of the labour market is to be considered secondary. Priority should be given to returning Lithuanian citizens. No steps followed, to convert this political document/declaration into an Action Plan. This was partly due to the expectation (and promises made by the Ministry of Foreign Affairs) that a new Programme for the Creation of a "Global Lithuania" (see below) would encompass all issues pertaining to emigration, return migration and immigration taking into account imminent demographic and economic/labour market problems and needs. As it turned out, however, when the awaited programme was finally approved, it included only a policy for maintaining ties with the diaspora.

- The Programme for the Creation of a "Global Lithuania" (Involvement of Lithuanian Emigrants in the Life of the State) for 2011-19, as approved in 2011, introduced a new approach to emigrant Lithuanian citizens, one that acknowledges the fact that they may be an asset to their country even if residing abroad. The aspiration to promote the return of Lithuanian citizens to their homeland remains, but the target group of the programme has been expanded to include citizens who do not intend to return to Lithuania, as well as aliens of Lithuanian descent or who have other links with Lithuania. The programme aims to ensure that emigrants from Lithuania preserve their national identity, promoting their involvement in the cultural, political and economic life of Lithuania, encouraging Lithuanians to return to Lithuania, and turning "brain drain" into "brain exchange", by involving the emigrants in the exchange and dissemination of information. The immigration of foreigners or the economic problems related to emigration are not addressed.

\section{Conclusion}

Emigration from Lithuania continues to be identified as one of the most urgent national problems, posing demographic as well as labour market problems, yet until recently very little has been done to stop such massive emigration, to encourage return migration (Sipavičienė et al., 2009) or to attract foreign labour force. 


\section{Notes}

1. The stages identified in this report are not absolute, of course. Migration does not always directly and immediately react to social, economic or political changes, and there is no clear-cut moment in time in which one migration model transforms into another. As a rule, these develop gradually, with different models co-existing for quite some time.

2. Third country national - a person who is not a citizen of an EU member state, or of a member of the European Free Trade Association (Norway, Switzerland, Lichtenstein and Iceland).

3. Resolution No. IX-1187, approved by the Seimas of the Republic of Lithuania on 12 November 2002 (Official Gazette, No. 113-5029, 2002).

4. Resolution No. 1350, approved by the Government of the Republic of Lithuania on 28 October 2004 (Official Gazette, No. 159-5795, 2004).

5. Resolution No. 416 approved by the Government of the Republic of Lithuania on 25 April 2007 (Official Gazette, No. 49-1897, 2007).

6. Resolution No. 1317 approved by the Government of the Republic of Lithuania on 3 December 2008 (Official Gazette, No. 143-5706, 2008).

7. Resolution No. 389 approved by the Government of the Republic of Lithuania on 30 March 2011 (Official Gazette, No. 42-1969, 2011). 


\section{References}

Apklausa: apie emigraciją vienaip ar kitaip mąsto puse šalies gyventojų [Poll: Half of the population somehow thinks about emigration] (2011), Delfi: www.delfi.lt/news/daily/ lithuania/apklausa-apie-emigracija-vienaip-ar-kitaip-masto-puse-salies-gyventoju.d?id =51966417; $\quad$ Spinter: $\quad$ www.spinter.lt/site/lt/vidinis/menutop/9/home/publish/ MzI5Ozk7OzA=.

Apklausa: daugelis lietuvių emigruoti visam laikui netrokšta [Poll: Many Lithuanians wish to emigrate permanently] (2012), Spinter: www.spinter.lt/site /lt/vidinis/menutop/9/home/publish/MzUyOzk7OzA=.

Frejka, T., M. Okolski and A. Sipavičienè (1998), "Economic and Social Consequences of International Population Movements in Central and Eastern Europe in the Early 1990s", International Population Conference, Peking, Vol. 1, pp. 7-19.

Gruževskis B. and R. Zabarauskaitè (2012), "Ekonominio nuosmukio socialinès pasekmès Lietuvoje", Lietuvos Socialine Raida, No. 1 [Social impact of the economic downturn in Lithuania, Lithuanian Social Evolution, No. 1].

IOM/EMN (2012), "Organization of Asylum and Migration Policy in Lithuania", IOM/EMN, Vilnius, http://emn.lt/wp-content/uploads/2013/06/3.Publication-ofOrganisation-of-Asylum-and-Migration-Policy-in-Lithuania-EN.pdf.

Karpavičius, K. (2006), "Emigracijos poveikis Lietuvos ekonomikai”, Pinigu studijos, No. 2 [Effects of emigration on the Lithuanian economy, Monetary Studies, No. 2].

Lietuva Stojant į Europos Sajungą. Ekonominè, sociologinė ir demografinè padèties analizè [Lithuanian accession to the European Union. Economic, sociological and demographic analysis], Vilnius.

Maldeikienè, A. (2010), "Macroeconomic Consequences of Migration", unpublished document.

Maslauskaitè, A. and V. Stankūnienè (2007), "Šeima abipus sienų. Lietuvos transnacionalinès šeimos genezè, funkcijos, raidos perspektyvos", Tarptautinè migracijos organizacija, Socialiniu tyrimu institutas [The family on both sides of the walls. Lithuania transnational family genesis, function, development prospects, International Organization for Migration, Institute for Social Research], Vilnius.

OECD (2011), "Free Mobility as an Adjustment to Economic Shocks? The Experience of Crisis", Growing Free Labour Mobility Areas and Trends in International Migration, http://dx.doi.org/10.1787/9789264177185-en.

Požiūris ị emigraciją ir emigrantus (2008), Tautinių mažumų ir išeivijos departamentas prie LRV, Tarptautinè migracijos organizacija [Approach to emigration and emigrants, National Minorities and Lithuanians Living Abroad under the Government, the International Organization for Migration], Vilnius. 
Sipavičienè, A. (2011), "Recent Developments in International Migration in Lithuania 2010”, SOPEMI Report for Lithuania, Report submitted to the OECD Expert Group on Migration, December 2011.

Sipavičienè, A. (2006), Tarptautine gyventoju migracija Lietuvoje: modelio kaita ir situacijos analyze, Tarptautinè migracijos organizacija, Socialinių tyrimu institutas [International population movement in Lithuania: change the model and analysis of the situation, International Organization for Migration, Institute for Social Research], Vilnius.

Sipavičienè, A. (ed.) (1997), "International Migration in Lithuania: Causes, Consequences, Strategy", Lietuvos filosofijos ir sociologijos institutas, Vilnius.

Sipavičienè, A. and V. Gaidys (2008), Požiūris i emigracija ir emigrantus, Tautiniu mažumų ir išeivijos departamentas prie LRV, Tarptautinè migracijos organizacija [Approach to emigration and emigrants. National Minorities and Lithuanians Living Abroad under the Government, the International Organization for Migration], Vilnius.

Sipavičienè, A. and M. Jeršovas (2010), Darbo jègos migracija: poreikis ir politika Lietuvoje [Labour migration: Lithuanian policy requirements], IOM, EMN, LSTC, Vilnius.

Sipavičienè A. and V. Stankūnienè (2011), "Lietuvos gyventojų (e)migracijos dvidešimtmetis: tarp laisvès rinktis ir išgyvenimo strategijos" [Migration of Lithuanian population over two decades: between freedom and survival strategy], Filosofija. Sociologija, No. 4.

Sipavičienè, A., V. Gaidys and M. Jeršovas (2009), Grį̌tamoji migracija: teorinès ižvalgos ir situacija Lietuvoje, Tarptautinè migracijos organizacija, Europos migracijos tinglas, Socialinių tyrimų Institutas, Tarptautinè migracijos organizacija, Socialinių tyrimų institutas [Return migration: theoretical insights and the situation in Lithuania. International Organization for Migration, Social Research Institute], Vilnius.

Stankūnienè, V. (ed.) (2002), Lietuvos gyventojai 1990-2000 [Lithuanian population 1990-2000], LFSI, Vilnius.

Stankūnienè, V. (1996), "Mobility of Scientists in Lithuania: Internal and External Brain Drain", Lithuanian Institute of Philosophy and Sociology, Vilnius.

Stankūnienė V., A. Sipavičienė and D. Jasilionis (2012), "Ekonominių nestabilumų poveikis demografiniams procesams", Lietuvos Socialinè Raida, No. 1 [Effects of economic instability on demographic processes, Lithuanian Social Evolution, No. 1].

Statistics Lithuania (2012), Demografijos metraštis, 2011-2012, Statistikos departamentas Statistics Lithuania [Demographic Yearbook, 2011-2012. Lithuanian Department of Statistics], Vilnius. 


\title{
Chapter 4
}

\section{Emigration from Latvia: Recent trends and economic impact}

\author{
Mihails Hazans
}

University of Latvia and Institute for the Study of Labour (IZA), Bonn

This chapter examines the substantial outflows of population from Latvia since 2000, which has major implications for the demography and development of Latvia as well as its social security system. Different statistical sources are described and compared. The chapter examines the characteristics of emigrants relative to the resident population, in terms of education, age, employment experience and income. The chapter examines the relationship between growth and emigration, as well as emigration potential, exploring the role of non-economic factors. The changing characteristics of emigrants from Latvia are discussed. The current and future impact of emigration on the labour market is examined. The chapter concludes by indicating some means for alleviating negative impact. 


\section{Introduction}

Since the beginning of the $21^{\text {st }}$ century, Latvia has lost $9.1 \%$ of its population (including almost $14 \%$ of its working-age population) in several waves of emigration. Three quarters of adult emigrants are younger than 35 at the time of their departure. Combined with a large negative natural increase, this causes the Latvian population to shrink and to age very quickly, much faster than that of the countries hosting Latvia's emigrants.

The main reasons for emigration, the most popular destinations, as well as the profile of the emigrant population and emigrants' plans, have changed substantially during this relatively short period. The most recent wave of emigration is associated with the economic crisis, which affected Latvia much more than most European countries. Figure 4.1 presents the economic and labour market context of this wave. At the end of 2009, Latvian GDP was $24 \%$ lower than the pre-crisis maximum. It took only six months longer for the number of legally employed persons to also shrink by one-fourth, while employment in full-time equivalents fell by almost one third.

Figure 4.1. Latvian real GDP and employment during the economic crisis

$$
2008 / \mathrm{Q} 2=100
$$

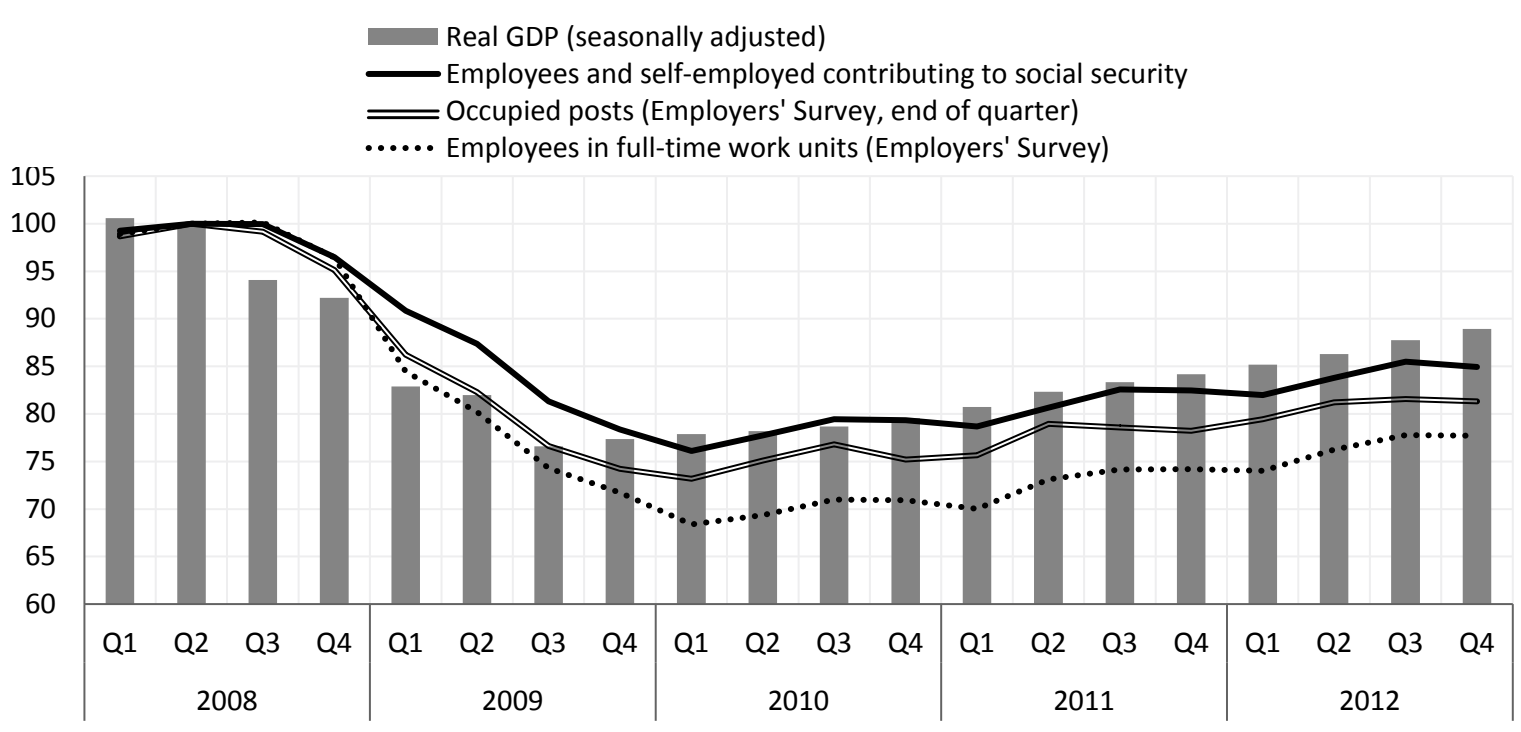

Source: Author's calculations based on data from Statistics Latvia and the State Social Insurance Agency.

Three years later, only half of the GDP decline and much less than half of the employment loss had been recovered.

Latvian emigration during the crisis stands out in the European Union as the most dramatic response to the crisis. According to the 2011 EU Labour Force Survey (EU-LFS), between 2008 and 2011 the stock of Latvian citizens aged 15-64 who arrived in another EU member state within the last three years increased by $47 \%$. A parallel increase for Hungarian and Estonian citizens was modest $(15 \%$ and $1 \%$, respectively, while a decrease was recorded for citizens of other CEE countries (ranging from $-4 \%$ for Bulgaria to $-17 \%$ for Lithuania and $-60 \%$ for Poland), see Aujean (2012). Moreover, Latvia is the only country among the EU8+2 for which the estimated impact of recession 
on net migration to EU15 countries in 2008-09 was positive (see European Commission, 2012, Chapter 6, Table 9, based on Holland et al., 2011). In terms of overall mobility rate (measured as the percentage of working-age population living in another EU member state) Latvia (6\%) is fourth among CEE countries, following Romania (12.5\%), Lithuania $(8.5 \%)$ and Bulgaria (7\%) and followed by Poland, Slovakia and Estonia (4\% to 5\%), as well as Hungary and Slovenia (2\% each) and Czech Republic (1.5\%), see Aujean (2012); see also European Commission (2012) for similar results based on EU-LFS 2010.

After EU enlargement in 2004, and especially during the crisis years of 2009-11, emigration reached levels that pose a threat to the reproduction of the Latvian population, the country's economic development and the sustainability of its social security system. Thus, some positive side effects notwithstanding, emigration has become a serious obstacle to human development and economic growth in Latvia. According to a recent survey, three quarters of Latvia's population perceive emigration as the single largest threat to the country and its people (Figure 4.2).

Figure 4.2. Share of Latvia's residents aged 18-74 who perceive the processes below as a major threat to Latvia and its people, July 2012

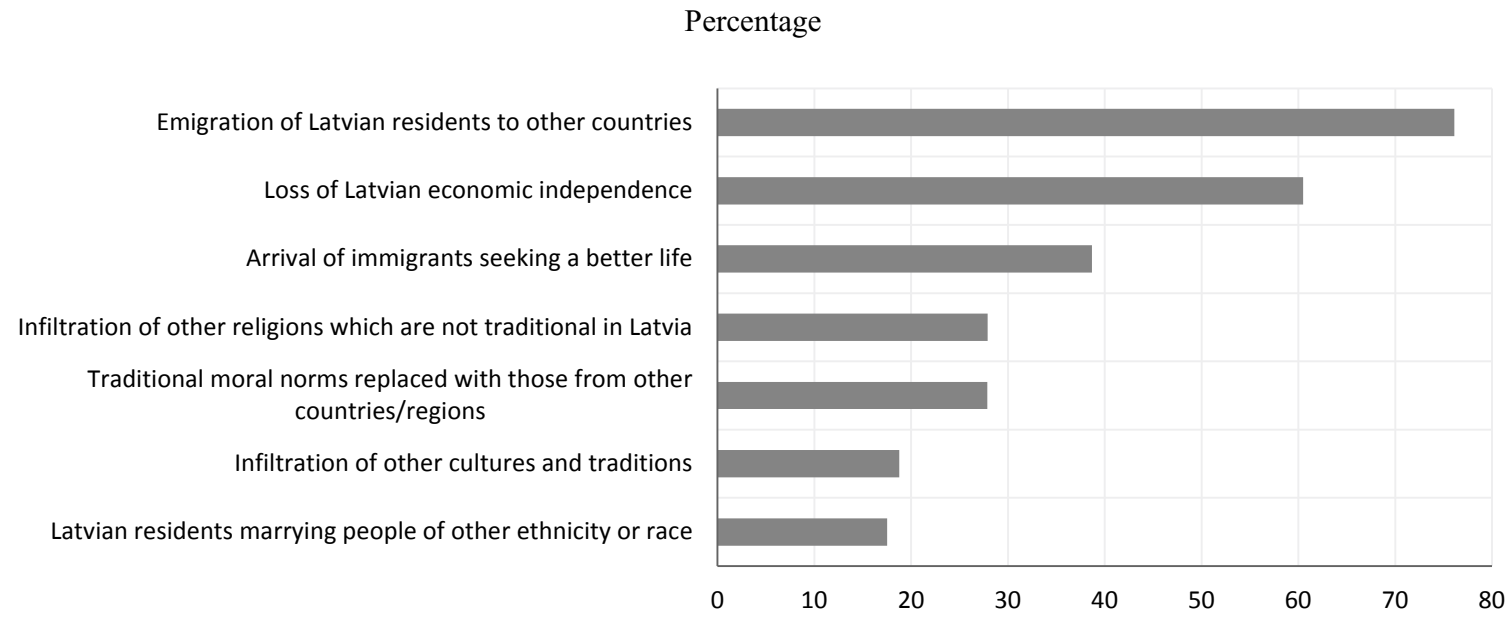

Source: SKDS (2012), The Popularity of National Ideas in Society Survey, Marketing and Public Opinion Research Centre (Latvia).

This chapter opens with an updated, revised and extended version of our previous emigration estimates for 2000-11. In this section we also compare Latvian and Estonian emigration in 2000-10. It then discusses whether there is evidence to suggest that emigration is substantially slowing down and will soon return to pre-crisis levels. It then presents a brief description of the history of three recent emigration waves shaped by economic and institutional developments in Latvia and in potential destination countries: i) the pre-accession period (which we have treated as loosely corresponding to 2000-03, although it also included the first four months of 2004); ii) the post-accession period, characterised by economic growth, corresponding to 2004-08 (the crisis hit Latvia in the last quarter of 2008, but its effect on emigration appears only in the data of 2009-11); iii) the crisis period, 2009-11 (data for 2012 are scarce). A number of hypotheses (or stylised facts) regarding the nature of the emigration flows in each of the periods will be put forward. We will then test these hypotheses through a quantitative analysis of migration processes and the migrant population profiles, using administrative and survey 
data. The next section explores changes in emigrant population profiles over time and compares emigrants, non-migrants and return migrants along various dimensions. The prospects of return migration are addressed, as are the development of migration networks, and the impact on return migrants of having lived abroad. The chapter then analyses intentions to emigrate in the Latvian population since the onset of the economic crisis. In conclusion, there is a discussion of the economic impact of emigration on Latvia.

\section{How many people left Latvia in 2000-11?}

Until late 2011, according to official Latvian statistics, net emigration from Latvia between 2000-10 amounted to 33000 persons. Hazans (2011a, 2011b) combined destination country (and, in some cases, Latvian) statistics on population and on bilateral migration flows by citizenship and/or country of birth, data on social security number (SSN) allocation in the United Kingdom and Ireland, and estimates of return migration to Latvia based on several population surveys, to arrive at an estimate of net emigration of the Latvian population during 2000-10 of at least 169000 (the most recent update of this estimate is 194000 , see Table 4.1 below). Estimates are essential due to the inevitable incompleteness of migration data as well as circumstances specific to Latvia: e.g., as of $2005,20 \%$ of the population aged 15-74 were not Latvian citizens, although most of them held Latvian (non-citizen) passports; 14\% were foreign-born; moreover, some destination countries classify persons born in Latvia in 1940-91 as born in the Soviet Union. The preferred expert estimate of net emigration during the period in question, as reported in Hazans (2011a, 2011b) was 200 000, while the upper expert estimate (total net emigration of 250000 persons) accounts for the fact that the 2011 census data yielded only 1880000 directly collected records (Statistics Latvia, 2012), or 348000 less than the population figure previously published on March 31, 2011.

Three months later, Krasnopjorovs (2011) published an independent but very close estimate of the outflow from Latvia $(178000)$ based on the difference between the numbers of passengers departing and arriving via Riga airport and sea port (this methodology is of course far from perfect, as it ignores migration by land).

Hazans $(2011 \mathrm{a}, 2011 \mathrm{~b})$ also presents a breakdown of net emigration by periods as described above as well as a comparison between Estonia and Latvia (Hazans, 2012). Table 4.1 below is based on these results, with updated entries for Latvia (labelled [2] and [3]) (see Tables 4.3 and 4.4 below for details).

In both countries, emigration rates at least doubled after accession to the European Union. Furthermore, during the crisis years (2009-10) the Latvian annual net emigration rate more than doubled again (compared to the post-enlargement period of 2004-08). In Estonia, the increase in the rate of emigration during the crisis was not nearly as sharp as in Latvia, despite a similarly deep recession: in 2009, GDP and employment (in full-time equivalents) in both countries were about 20\% below 2007 levels (see Figure 4.1 for Latvia).

However, Estonia, which created a stabilisation fund during the years of economic growth, managed without external help, and experienced more modest wage cuts than Latvia (European Commission, 2011, Graph I.3.1). Moreover, the crisis in Latvia was perceived by the majority of the population as a systemic - rather than merely financial crisis, which was not the case in Estonia. Table 4.2 illustrates these differences. 
Table 4.1. Net emigration from Estonia and Latvia, 2000-10

Sending and receiving country estimates

\begin{tabular}{|c|c|c|c|c|c|c|c|c|c|c|c|c|c|c|}
\hline & \multicolumn{7}{|c|}{ Estonia } & \multicolumn{7}{|c|}{ Latvia } \\
\hline & \multirow{2}{*}{\multicolumn{3}{|c|}{$\frac{\text { Persons }}{\text { (thousands) }}$}} & \multicolumn{4}{|c|}{ Net migration rate, $\%$} & \multirow{2}{*}{\multicolumn{3}{|c|}{$\frac{\text { Persons }}{\text { (thousands) }}$}} & \multicolumn{4}{|c|}{ Net migration rate (\%) } \\
\hline & & & & \multicolumn{2}{|c|}{ Annual average } & \multicolumn{2}{|c|}{$\begin{array}{l}\text { Period total } \\
\text { (vs. initial } \\
\text { population) }\end{array}$} & & & & \multicolumn{2}{|c|}{ Annual average } & \multicolumn{2}{|c|}{$\begin{array}{l}\text { Period total } \\
\text { (vs. initial } \\
\text { population) }\end{array}$} \\
\hline & [1] & [2] & {$[3]$} & [2] & {$[3]$} & [2] & [3] & [1] & [2] & [3] & [2] & {$[3]$} & [2] & [3] \\
\hline 2000-03 & 7.3 & 12.2 & 15 & 0.22 & 0.27 & 0.9 & 1.1 & 13.3 & {$[30.0 ; 40.0]$} & 45 & 0.38 & 0.48 & 1.5 & 1.9 \\
\hline 2004-08 & 9.7 & 35.1 & 44 & 0.54 & 0.65 & 2.6 & 3.2 & 7.2 & {$[83.6 ; 90.4]$} & 87 & 0.78 & 0.78 & 3.8 & 3.8 \\
\hline 2009-10 & 3.3 & 18.5 & 25 & 0.72 & 0.94 & 1.4 & 1.9 & 12.6 & [71.4; 72.5] & 80 & 1.68 & 1.89 & 3.3 & 3.7 \\
\hline 2000-10 & 20.2 & 65.8 & 84 & 0.46 & 0.56 & 4.8 & 5.9 & 33.1 & 194.5 & 212 & 0.79 & 0.88 & 8.2 & 8.9 \\
\hline
\end{tabular}

1. Official sending country estimates (as of September 2011).

2. Conservative documented estimates based on receiving countries' population and/or migration statistics by citizenship and/or country of birth (for countries outside the European Union and OECD, sending country statistics was used). Inflows into Ireland and the United Kingdom are estimated using data on the allocation of social security numbers, while data on outflows from the United Kingdom and Ireland have been adjusted upwards (especially for 2004-08) using Latvian and Estonian LFS and other population surveys.

3. Realistic expert estimates based on [2] and accounting for the fact that receiving countries' immigration statistics are incomplete both in general and especially regarding inflows from Latvia and Estonia due to large proportions of non-citizens and foreign-born in these two countries.

Source: Eurostat, OECD, Statistics Latvia, Statistics Estonia, other national statistical offices, Department of Work and Pensions (United Kingdom), Department of Social Protection (Ireland), author's calculation and compilation.

Table 4.2. Public sentiment indicators during the economic crisis

\begin{tabular}{|c|c|c|}
\hline & Estonia & Latvia \\
\hline & (Nov. 2008 - Feb. 2009) & (Apr. 2009 - Aug. 2009) \\
\hline Satisfaction with the state of the country's economy & 3.53 & 1.81 \\
\hline Satisfaction with the national government & 3.53 & 1.8 \\
\hline Satisfaction with the state of education & 5.86 & 4.62 \\
\hline Satisfaction with the state of health services & 5.07 & 3.53 \\
\hline Satisfaction with the way democracy works in the country & 4.52 & 3.27 \\
\hline Trust in the country's parliament & 3.88 & 1.95 \\
\hline Sample size & 1661 & 1980 \\
\hline
\end{tabular}

Note: Satisfaction and trust are measured at the 0-10 scale. The table reports mean values (excluding non-response). Standard errors in all cases are between 0.04 and 0.06 .

Source: Author's calculations based on data from the European Social Survey (2008-09).

While current (February 2013) official estimates of emigration from Latvia are more realistic than those published a year earlier, the underlying methodology of the 2011 population census suffers from limitations both in terms of data collection and in terms of allocating unregistered outflows to particular years (see Annex 4.A1 for details). Figures 4.3 and 4.4, as well as Tables 4.3 and 4.4, present our alternative estimates, which update, revise and extend those by Hazans (2011a, 2011b) and rely heavily on receiving country data (see Box 4.1 for details). 
Figure 4.3. Alternative estimates of net emigration from Latvia, 2000-11

Thousands

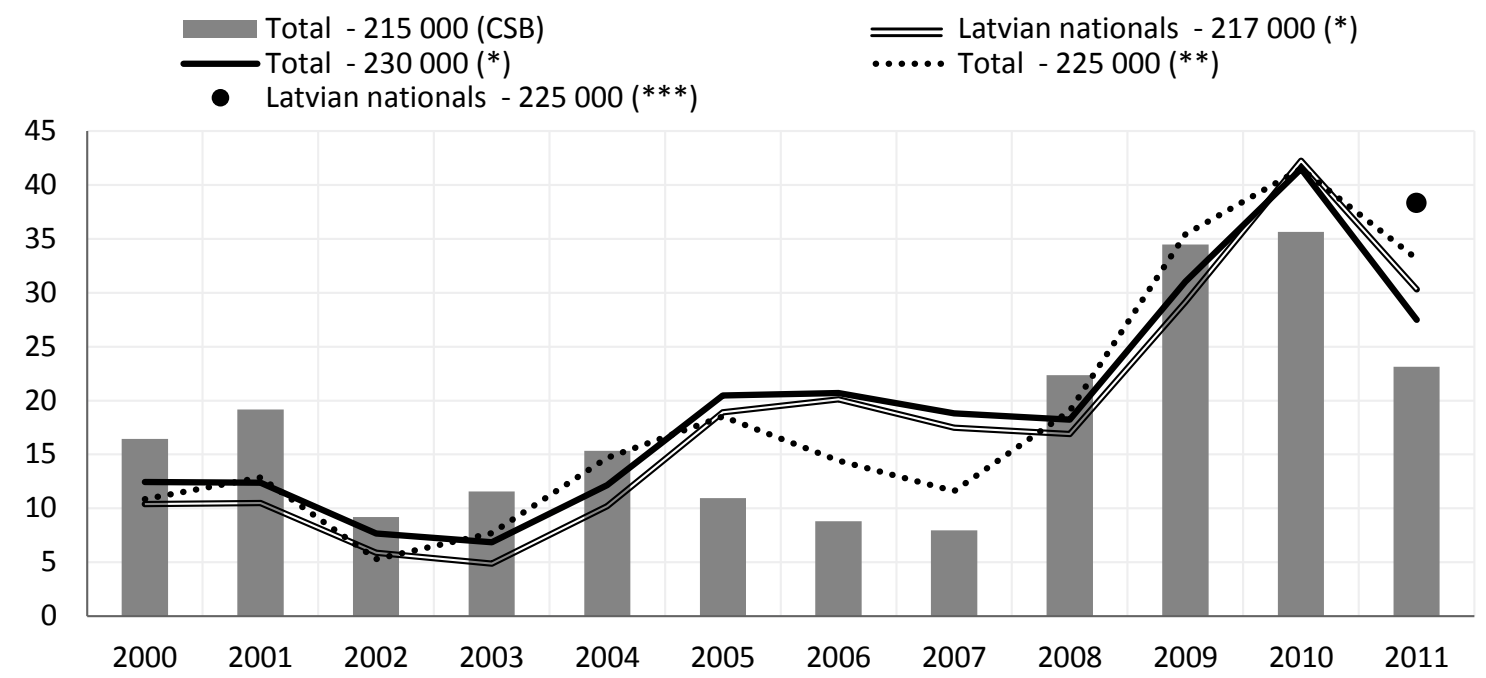

Source: CSB - official data (Statistics Latvia, as of January 2013). (*) Receiving country data compiled by the author and complemented with Latvian data for countries outside the EEA and OECD. (**) Statistics Latvia data corrected by the author. $(* * *)$ Emigration data as in $(*)$ combined with Statistics Latvia immigration data for 2011.

Figure 4.4. Net emigration of Latvian nationals by destination, 2000-11

Thousands

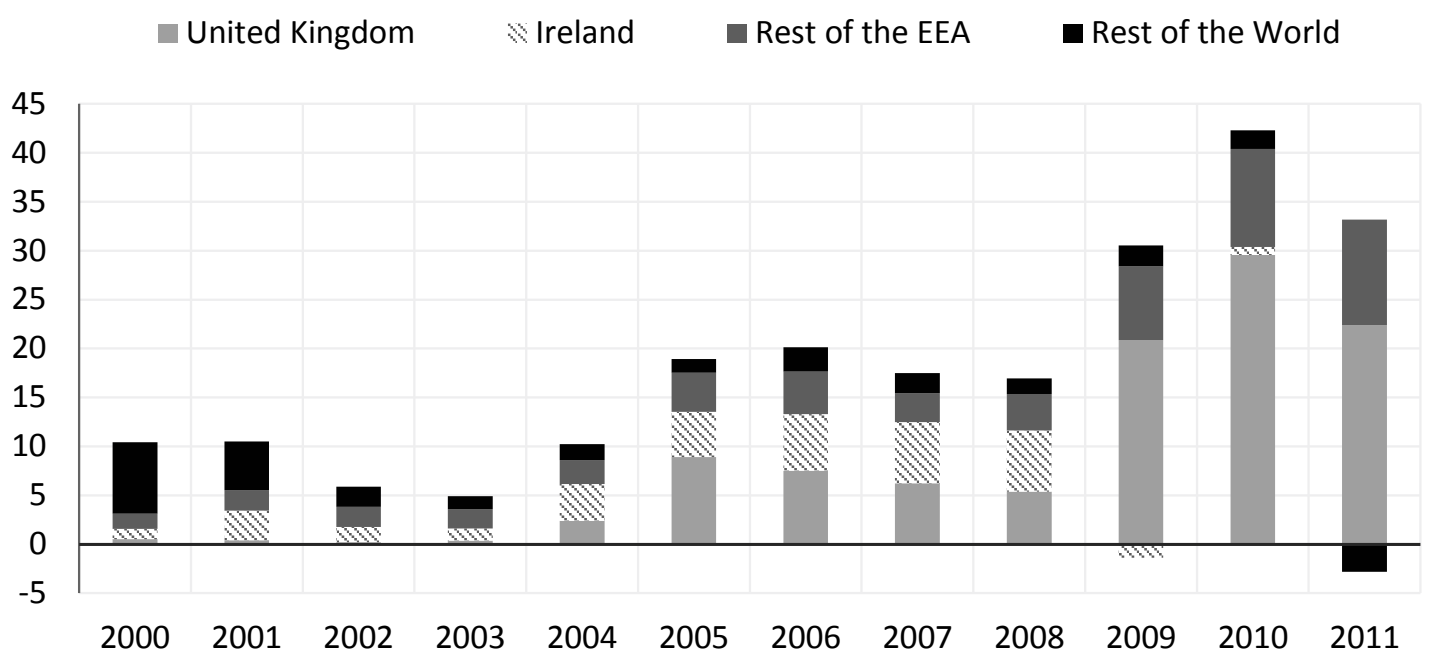

Source: Eurostat, OECD, Statistics Latvia, other national statistical offices, Department of Work and Pensions (United Kingdom), Department of Social Protection (Ireland), author's calculation and compilation and Box 4.1. 
Table 4.3. Net emigration of Latvian nationals by destination, 2000-11

Thousands

\begin{tabular}{c|cccccccc}
\hline$[1]$ & {$[2]$} & {$[3]$} & {$[4]$} & {$[5]$} & {$[6]$} & {$[7]$} & {$[8]$} \\
\hline & & & & & Former Soviet \\
Union & Rest of the \\
Year & $\begin{array}{c}\text { United } \\
\text { Kingdom }\end{array}$ & Ireland & Rest of the EEA & $\begin{array}{c}\text { OECD } \\
\text { countries }\end{array}$ & Rest of World & Total \\
\hline 2000 & 0.50 & 1.05 & 1.58 & 0.74 & 2.76 & 3.77 & 10.40 \\
2001 & 0.40 & 3.02 & 2.10 & 0.97 & 1.12 & 2.89 & 10.49 \\
2002 & 0.21 & 1.54 & 2.07 & 0.90 & 1.08 & 0.08 & 5.88 \\
2003 & 0.37 & 1.23 & 1.97 & 0.54 & 0.69 & 0.07 & 4.88 \\
2004 & 2.38 & 3.76 & 2.44 & 0.65 & 0.95 & 0.03 & 10.22 \\
2005 & 8.88 & 4.64 & 4.00 & 0.76 & 0.59 & 0.05 & 18.91 \\
2006 & 7.50 & 5.79 & 4.34 & 0.93 & 1.47 & 0.08 & 20.10 \\
2007 & 6.23 & 6.22 & 2.98 & 0.70 & 1.32 & 0.03 & 17.47 \\
2008 & 5.38 & 6.22 & 3.75 & 0.40 & 1.15 & 0.02 & 16.91 \\
2009 & 20.84 & -1.39 & 7.55 & 0.57 & 1.44 & 0.13 & 29.15 \\
2010 & 29.56 & 0.79 & 10.02 & 0.64 & 1.14 & 0.12 & 42.26 \\
\hline 2011 & 22.37 & -0.03 & 10.79 & 0.80 & -3.71 & 0.11 & 30.33 \\
\hline $2000-11$ & 104.61 & 32.84 & 53.59 & 8.50 & 10.90 & 7.38 & 217.00 \\
\hline
\end{tabular}

Note: In columns [6] and [7] we report total net emigration rather than emigration of nationals.

Source: Eurostat, OECD, Statistics Latvia, other national statistical offices, Department of Work and Pensions (United Kingdom), Department of Social Protection (Ireland), author's calculation and compilation.

Table 4.4. Alternative documented estimates of net emigration from Latvia, 2000-11

Thousands

\begin{tabular}{lr|r|r|r}
\hline & $\begin{array}{c}\text { Latvian } \\
\text { nationals }\end{array}$ & Total $^{1}$ & Total $^{2}$ & $\begin{array}{c}\text { Air and sea } \\
\text { passengers }\end{array}$ \\
\hline 2000 & 10.4 & 12.4 & 16.4 & .a. \\
2001 & 10.5 & 12.4 & 19.2 & n.a. \\
2002 & 5.9 & 7.7 & 9.2 & 5.5 \\
2003 & 4.9 & 6.9 & 11.6 & 5.5 \\
2004 & 10.2 & 12.2 & 15.3 & 10.3 \\
2005 & 18.9 & 20.5 & 11.0 & 7.5 \\
2006 & 20.1 & 20.7 & 8.8 & 13.1 \\
2007 & 17.5 & 18.8 & 7.9 & 10.6 \\
2008 & 16.9 & 18.2 & 22.4 & 23.8 \\
2009 & 29.1 & 31.0 & 34.5 & 47.5 \\
2010 & 42.3 & 41.5 & 35.6 & 43.2 \\
2011 & 30.3 & 27.5 & 23.1 & 27.6 \\
$\mathbf{2 0 0 0 - 1 1}$ & $\mathbf{2 1 7 . 0}$ & $\mathbf{2 2 9 . 7}$ & $\mathbf{2 1 5 . 0}$ & $\mathbf{1 9 4 . 6}$ \\
& & & & $\left(\mathbf{2 1 4 . 5}{ }^{4}\right)$ \\
\hline
\end{tabular}

1. Receiving country data compiled by the author and supplemented with Latvian data for countries outside the EEA and OECD.

2. Statistics Latvia data (see Annex 4.A1 for details). The data are as reported in January 2013. Statistics Latvia (2013a) revised the 2011 figure to 20100 , using methodology which is not comparable with previous years and may underestimate both gross and net emigration (Baltic Course, 2013; LETA, 2013).

3. Krasnopjorovs (2012), based on data from Statistics Latvia.

4. Assuming figures from the first column for 2000-01.

Source: Eurostat, OECD, Statistics Latvia and other national statistical offices; Department of Work and Pensions (United Kingdom), Department of Social Protection (Ireland), Krasnopjorovs, O. (2012), "Vai emigrācijas vilnis izsīkst?" (Does emigration slow down?), www.makroekonomika.lv/vai-emigracijas-vilnis-izsikst and author's calculation and compilation. 


\section{Box 4.1. Our methodology for estimating net emigration}

For every destination country $\mathrm{F}$ and every year between 2000 and 2011, we have calculated all available estimates of net emigration (based on Eurostat, OECD and national statistics data):

1) net inflow of Latvian citizens to $F$ based on migration flows; 2 ) net inflow of Latvian citizens to $F$ based on the population figures by citizenship, and acquisition of citizenship by former Latvian citizens; 3 ) net inflow of persons born in Latvia into F based on migration flows; 4) net inflow of persons born in Latvia into F based on the population figures by country of birth; 5) total net inflow from Latvia to F based on migration flows by country of previous or next residence.

For each year, the largest of the above estimates (1)-(4) was used as the component of our first time series, net outflow of Latvian nationals to F, reported in Table 4.3 and presented in Figure 4.4.

On the other hand, estimate (5) was calculated using all available combinations; the maximum figure was used in each case as the component of our second time series, total net emigration from Latvia to F. For countries/years where the component of one of the series was missing, the respective component from the other has been used instead. In most cases, net emigration of "foreigners" was positive, thus the second series gives somewhat higher emigration figures.

Inflows into Ireland and the United Kingdom are estimated using full-coverage data on allocation of social security numbers (SSNs); for the United Kingdom these data are for adults only, so they have been adjusted using the age structure of migration flows from Latvia to other EEA countries for the respective years. SSNs are issued only once, at the first migration, so do not capture exits and subsequent returns. Data on outflows from the United Kingdom and Ireland to Latvia during the post-enlargement period of 2004-08, when migration was predominantly short-term and circulatory, have been adjusted to account for $40 \%$ of gross registered inflows from Latvia to these countries during this period (according to estimates from the Latvian LFS, as well as various population surveys, see Hazans and Philips (2010), Hazans (2011b) for details). Note that total outflows from other EEA countries to Latvia in 2004-08 matched the 40\% estimate well, and did not require correction. During the crisis years 2009-11, return migration to Latvia was less intensive. We thus applied a $10 \%$ return rate to gross inflows into the United Kingdom in these years, while uncorrected migration statistics were used for other countries.

Ireland is a special case which requires more explanations. For 2005-10, net emigration of Latvian nationals to Ireland was much larger when calculated as change in stock (which was actually used) rather than as net flow (even if gross outflows are based on allocation of the Irish social security numbers to Latvia's nationals); the overall difference, strongly positive in 2007-08 but negative in 2009, amounts to 5400 . Note that substantial outflows of Latvian citizens from Ireland have been recorded in 2009-10, but survey and anecdotal evidence indicate that many left for countries other than Latvia. Yet the estimated total (rather than only Latvian citizens) net outflows from Latvia to Ireland in 2008-10 are positive (these alternative data are used in the second time series reported in Table 4.3).

1. The term "foreigners" is not limited to recent immigrants, as it may also include persons born in Latvia or living there for more than 20 years who hold other citizenships (mostly Russian, Ukrainian, Belarusian and of other former Soviet republics) or who are Latvian non-citizens. The latter category appears separately in Latvian statistics, but appears neither separately nor as "recognised non-citizens" or "stateless" in Eurostat data for most years, nor is it accounted for as a sub-category of Latvian citizens.

Figure 4.3 and Table 4.4 present, for each year from 2000 to 2011, two of our net emigration estimates: one refers to Latvian nationals, while the other looks at total migration flows (see Box 4.1 for details). Two of our series are quite close to each other in terms of both size and dynamics and are consistent with the expectation (supported also by evidence from the EU-LFS, see e.g. Brucker et al. (2009), Fic et al. (2011), and the European Commission (2012), that emigration after EU enlargement has been substantially higher than pre-enlargement emigration. An analysis of the dynamics of the net outflow of passengers from Riga airport and Riga port (Krasnopjorovs, 2012a; shown 
in Table 4.4) is also consistent with our estimates. Statistics Latvia figures are shown alongside our estimates.

Our estimates imply a slightly higher overall outflow between 2000 and 2011 than the estimates of Statistics Latvia. The important difference, as already mentioned, mainly concerns the dynamics. Data sources for our estimates are predominantly those of destination countries, while Statistics Latvia estimates combine Latvian administrative data with information provided by respondents of the 2011 population census using a mathematical procedure which ignores the difference in selectivity patterns between registered and unregistered emigrants (see Annex 4.A1 for details). Figure 4.3 includes (as the dotted line labelled $* *$ in the legend) another time series which for years 2000-10 is based on the same Latvian data used by Statistics Latvia but different (in our opinion, more realistic) assumptions (see Annex 4.A1 and Figure 4.A1.1, Panel B).

Our methodology (see Box 4.1 for details) is based on two well-known facts: migration is better captured at the receiving rather than at the sending country; most migration estimates are incomplete (in the Latvian case, as mentioned above, there are also special reasons for the latter).

Figure 4.4 breaks down net annual outflows of Latvian nationals by four destinations: the United Kingdom; Ireland; other EEA countries (an area which includes, apart from the EU member states, two important destinations for Latvian emigrants: Norway and Switzerland); and the rest of the world. Underlying statistics are presented in Table 4.3, which further subdivides the destinations outside of the EEA into three groups: OECD countries (here, non-negligible outflows to the United States, Canada, Australia and Israel can be observed), former Soviet republics, and other destinations.

\section{Is emigration slowing down?}

Since the beginning of 2011, the above question has been the focus of public debate. Some observers (Krasnopjorovs, 2011, 2012a among others) argued that 2011 was a turning point, and that in 2012, emigration slowed down further. Let us have a careful look both at the question and the data.

Emigration may have slowed down from the 2010 peak, but has it reached pre-crisis levels? The 2008 outflows should serve as the benchmark in this case, while the outflows observed in 2009 indicate the "height" of the crisis-triggered emigration wave. Only when emigration falls well below the 2009 level, one can talk about the turning point; and only when the absolute size of the outflow will become comparable to that observed in 2008 , one can say that the "exodus" is more or less over (strictly speaking, one should compare emigration rates, and this test is even harder to pass, as the population size is declining).

Should one use gross or net outflows to judge emigration trends? While net outflows are, arguably, more important in terms of impact, gross outflows can be measured more accurately, at least when data on SSN allocation are available from the countries of destination (as is the case of the United Kingdom and Ireland).

As far 2011 is concerned, our estimates based on destination country data (the first two columns in Table 4.4; see also lines in Figure 4.3) do not suggest that net emigration returned to levels close to the pre-crisis ones or significantly lower than the ones observed in 2009. ${ }^{1}$ Nor does this seem to have happened in 2012. In 2012, gross outflows to the United Kingdom (which exclude children), Germany and the Nordic countries, along with 
data for flows to the Russian Federation from Statistics Latvia, sum up to 29200 . This is higher than the official Statistics Latvia (2013a) estimate for emigration to all destinations, 25 200, based on a methodology (Statistics Latvia, 2013b, 2013c) which is not comparable with previous years and may underestimate both gross and net emigration (Baltic Course, 2013; LETA, 2013).

Figure 4.5 presents, across the years 2008-12, reliable information (available as of August 2013) on dynamics of gross outflows to the United Kingdom, Ireland, Germany, the Nordic countries and the Russian Federation, as well as net emigration from Latvia to Germany and the Nordic countries. Registered emigration (to all destinations) as well as the official estimate of total emigration are shown for comparison.

Figure 4.5. Outflows to main destination countries and registered emigration, 2009-12 Index $100=2008$ for each destination

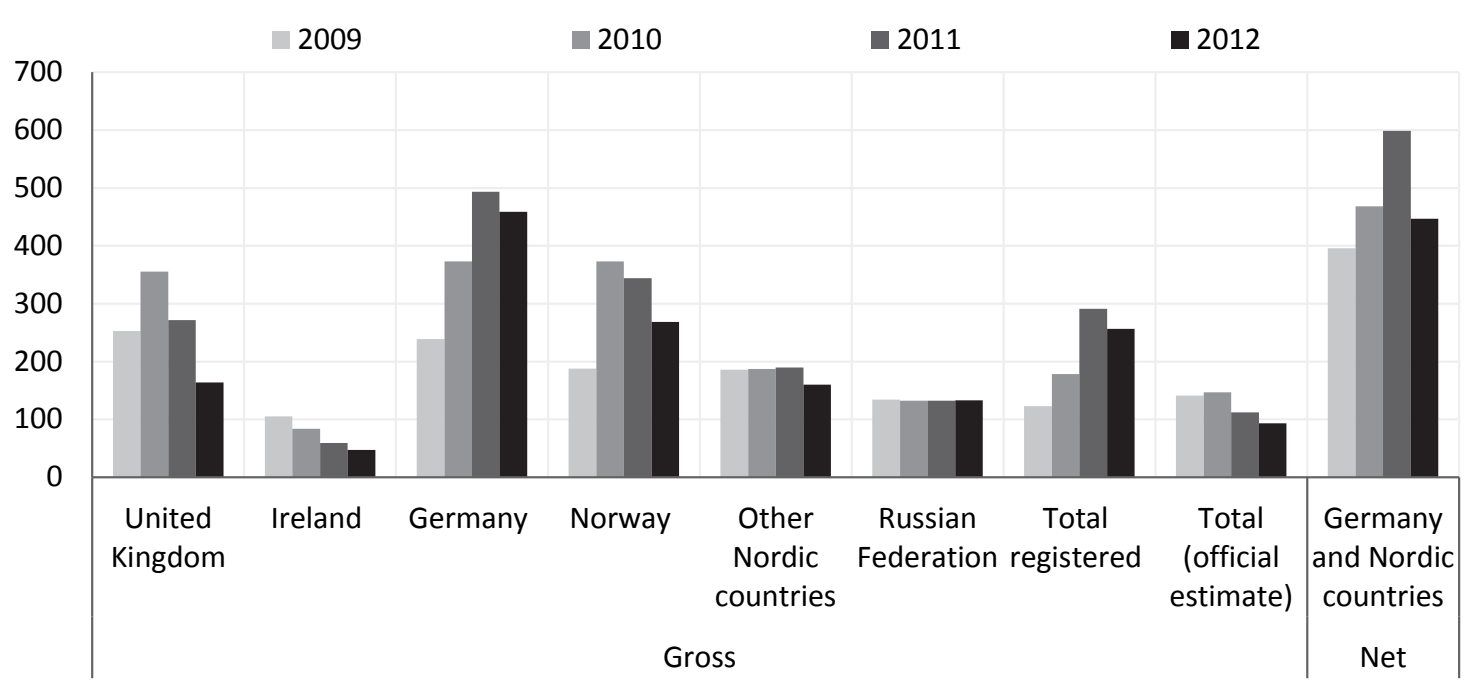

Note: Total registered emigration data for 2012 is a forecast based on the first nine months.

Source: Author's calculations based on data from the Department of Work and Pensions (the United Kingdom), the Department of Social Protection (Ireland), the national statistical offices of Norway, Sweden, Denmark, Finland and Germany, Statistics Latvia. German data for 2012 as reported by Düll, N. (2013), "Geographical Labour Mobility in the Context of the Crisis: Germany", European Employment Observatory.

With the exception of Ireland (where worsening economic conditions explain the decline), gross outflows to all main destinations in 2012 remain well above the pre-crisis level: the ratio of the 2012 outflow to the 2008 one is 1.6 for the United Kingdom, 4.6 for Germany, 2.7 for Norway, 1.6 for other Nordic countries (taken together) and 2.6 for total registered emigration. ${ }^{2}$ Likewise, net outflow to Germany and all Nordic countries together was 4.5 times higher in 2012 than in 2008. This evidence contradicts the official estimate indicating that the gross outflows in 2012 fell back to 2008 levels.

On the other hand, the data indicate a clear decline of emigration in 2012 as compared to 2011. Gross outflows to Norway declined by $22 \%$, to other Nordic countries by $16 \%$, to Ireland by $20 \%$ and to Germany by $9 \%$. Emigration to the United Kingdom fell by $40 \%{ }^{3}$ Total registered emigration in the first nine months of 2012 fell by $12 \%$ against corresponding period of 2011. Net emigration to Germany and Nordic countries declined by $25 \%$, a steeper decline than the fall in gross emigration, indicating a higher level of return. 


\section{Emigration from Latvia: Three waves in a decade}

According to the human capital model of migration (Sjaastad, 1962; Borjas, 1987, 1999), an individual (or a family) decides whether to move by comparing expected benefits and costs associated with migration. In order to assess [net] benefits, one should account for all factors that can affect the quality of life in the country of origin and in the potential country of destination: job-finding and job-losing probabilities, expected earnings, legal status, career prospects, working and living conditions, generosity of the social security system, social and cultural norms, perceived life prospects for children, etc. These factors can interact with each other in a variety of ways. For instance, the attractiveness of longterm migration is significantly undermined if, in the case of job loss in the country of destination, the immigrant has to apply for a work permit repeatedly. The same is true if employment protection and/or unemployment assistance legislation in the country of destination does not cover the immigrants to the same extent as it does native workers.

The determinants of migration flows are often subdivided into two groups: push factors are related to negative (undesired) circumstances in the country of origin, whereas pull factors are those which make potential destination countries attractive (Lee, 1966). A factor can play both roles either simultaneously (for instance, in 2009-10, high unemployment in Latvia was a push factor, but low unemployment in Norway was a pull factor) or depending on circumstances (for instance, the wage level is a pull factor for professionals who earn LVL 600 (EUR 854) per month in Latvia but can earn three to five times more abroad, while it is a push factor for those whose earnings in Latvia are not sufficient to support their family).

The costs of migration, in turn, include monetary as well as non-monetary costs (e.g., effort) and can be subdivided into the following categories: i) costs related to acquiring the necessary information and job search costs; ii) transportation costs; iii) costs of maintaining contact with the country of origin; iv) psychological costs related to missing people and the environment one has left behind, uncertainty associated with life in the new country, and adaptation to the new reality.

This framework will help us to understand the individuals' migration decisions, as well as the characteristics which drive emigrants' self-selection, in other words, which groups have a higher propensity to emigrate in a specific situation.

\section{The pre-accession wave: Personal initiative and effort}

Between 2000 and 2003, Latvia featured rather high unemployment (above 10\% according to Latvian Labour Force Survey data), combined with very low wages. Average earnings in the public sector (at purchasing power parity) were well below those of an unskilled worker in the United Kingdom, Germany or the Nordic countries. ${ }^{4}$ Therefore, many people in Latvia were dissatisfied with their material well-being and were considering permanent or temporary emigration as a solution to their problems. According to a survey of the economically active population conducted in 2000 (see Rose, 2000, or Hazans, 2003, Table 3.3), 8\% of ethnic Latvians and 25\% of their minority counterparts said that they (or some family member) would like to work abroad (at least) for a number of years, when their country enters the European Union. Moreover, $4 \%$ of Latvians and $9 \%$ of non-Latvians were ready to emigrate permanently. Higher propensity to emigrate among non-Latvians can be explained by the fact that their labour market situation at that time was, on average, worse than that of the ethnic (titular) Latvian population (Hazans, 2010, 2011a), as well as by their relatively weaker sense of 
belonging to Latvia (see Zepa and Kḷave, 2011). These data imply that in the year 2000, about $15 \%$ of the economically active population of Latvia was willing to work abroad, and half of them were considering permanent emigration. According to the same survey, another $25 \%$ of the labour force were considering emigration as a possibility. Thus, a sizeable emigration potential existed.

Actual emigration rates were of course much lower (see Table 4.1). Emigration was limited not only by hopes for a better life in Latvia (in 2000-03, unemployment was slowly but steadily decreasing and earnings were growing faster than consumer prices), but also by an institutional environment which was not favourable to economic migration, and by very high migration costs. Both residence and work permits were necessary unless one was ready to take on the risk of illegal immigration and/or employment. In addition, Latvian non-citizens needed visas to enter most EU member states. Looking for a job abroad was much more difficult and expensive than it is now. International phone calls from Latvia were very expensive; internet access was limited, slow, and expensive; air travel was costly. Moreover, there were no convenient extensive sources of information on vacancies and living and working conditions abroad such as the European Employment Services (EURES) portal, ${ }^{5}$ developed after 2004, where this information is available even in Latvian.

The services of private recruitment firms were expensive and often associated with a high risk of fraud. In an online survey conducted in Latvia in 2003, among 2100 respondents who said that after EU accession they would be ready to work in another EU country, $89 \%$ asserted that they would move only with a work contract in hand, and only $20 \%$ considered a contract with a licensed Latvian recruitment firm as a sufficient guarantee (Hazans, 2003, Tables A2.12, A2.13).

In brief, rather high de facto thresholds having to do with people's own initiative, access to information, and willingness to accept risk limited economic emigration in the pre-accession period. In such a situation, emigration costs would have been relatively lower for potential emigrants with a high level of initiative, professional or at least private contacts in possible destinations, good foreign language and IT skills, and opportunities to use the internet for private purposes at the workplace. Clearly, all these attributes are more often found among university graduates.

Emigrants' choice of destination was also probably affected by cost considerations: while some tried to minimise information and adaptation costs using social networks associated with previous waves of migration to/from the United States, Canada, Australia, Sweden and Germany, as well as the Russian Federation, Ukraine and Belarus, others were oriented towards relatively new directions, mainly the United Kingdom and Ireland (which combined lower language barriers than other EU countries with being much closer than other English-speaking countries), but also to other countries of "Old Europe".

Thus, theoretical considerations suggest that:

\section{(H1) In 2000-2003, economic emigrants from Latvia featured:}

a) a higher than average proportion of people with tertiary education

b) a higher than average proportion of ethnic minorities

c) a high degree of geographical diversification.

Note that the latter point is well supported by data presented in Figure 4.4. 


\section{Post-accession emigration: Institutional and market factors}

During Latvia's first five years within the European Union (before the effect of the crisis on migration patterns became apparent), migration flows were shaped mainly by two factors: i) gradual implementation of free movement of labour within the European Union (see Brucker et al., 2009, Table 2.1); ii) economic growth in Latvia as well as in potential destinations.

Economic growth in Old Europe resulted in an increased demand for labour, thus enhancing expected gains for potential economic emigrants and stimulating migration. On the other hand, due to strong economic growth in Latvia, the unemployment rate was falling while real wages were rising, gradually reducing expected gains from emigration. As a result, motivation to move abroad was falling, whilst motivation to return among recent emigrants was on the rise. ${ }^{6}$

For Latvians, the introduction of free movement of labour within the European Union lowered both the monetary and the non-monetary costs of job search abroad and migration, thus stimulating emigration. By contrast with the relatively slow changes in Latvia's labour market, the institutional changes had an almost immediate effect. Since May 1, 2004, citizens of Latvia and other new member states have been able to compete for jobs in Ireland, the United Kingdom and Sweden on equal terms with local workers. ${ }^{7}$ This reduced the psychological and adaptation costs of migration, as well as the risk of failed labour migration. At the same time, the European Mobility Portal and consultants of the EURES started to work in Latvia (and elsewhere in Europe). EURES consultants provided about 10000 consultations in 2004-05, followed by 12000 in 2006-07. This substantially reduced information and job search costs for potential emigrants.

Migration-friendly institutional changes boosted demand for international transportation and telecommunication services. As a result, the lower end of the passenger and cargo transportation market grew significantly across Europe (including Latvia), causing air and land transportation costs, as well as international phone call tariffs to fall. Communication costs were also reduced due to increased coverage and speed of internet connections. This, in turn, further reduced both direct and indirect (e.g., job search) costs of migration. Another side effect of the EU provisions for free movement of labour are the growing Latvian diasporas in Ireland, the United Kingdom, Sweden, Germany and elsewhere in Europe. Rich social infrastructure (including printed and electronic media) within these diasporas (see SKDS, 2006; Hazans and Philips, 2010) also helped to reduce the risk of "failed emigration" as well as the information, job search and psychic costs of migration.

Several factors contributed to a further decline in emigration costs and related risks. First, thanks to ongoing emigration and return migration, potential emigrants could increasingly rely on relatives and friends as a source of information about work abroad (this is known as social network or migrant network effect). Second, a number of countries (Finland, Greece, Italy, Portugal and Spain; in part also Norway) opened their labour markets in 2006; the Netherlands and Luxembourg followed in 2007 (see Brucker et al., 2009, Table 2.1 for details).

As the result of these developments, the threshold for potential emigrants with respect to personal initiative and risk taking was not as high as before EU accession. Hence, in 2004-08 emigrants' self-selection in terms of human capital was driven not so much by individuals' relative advantage in terms of [falling] migration costs, but mainly by expected gains in terms of income and working conditions. These gains were, on average, greater for 
persons with secondary education or less. For instance, in 2005 employees with tertiary education in Latvia earned 54\% more than otherwise similar workers with secondary education and $76 \%$ more than those with less than secondary education (Hazans, 2007). On the other hand, $40 \%$ to $50 \%$ of tertiary educated Latvian migrant workers abroad in 2004-07 held jobs which did not require a higher education (Hazans and Philips, 2010) and hence could not earn much more than other emigrants from Latvia. ${ }^{8}$

The effect of ethnicity and citizenship on the propensity to emigrate has also changed. Due to strong economic growth and labour shortages caused by emigration (see, for example, Hazans and Philips, 2010, Section 7 and Figure 12), as well as gradual improvements in language skills among minorities (Hazans, 2010, Figure 3; Hazans, 2011a, Tables 8.8 and 8.9), the labour market position of ethnic minorities in 2004-07 steadily improved. Economic activity and employment rates among non-Latvians were growing faster than among Latvians, thus reducing the ethnic employment gap (which disappeared completely by 2007 , see Hazans, 2010, 2011a). In addition, a substantial part of the minority population - those without Latvian citizenship - was not covered by the legal provisions on free movement of labour. ${ }^{9}$

To sum up, theoretical considerations suggest that:

\section{(H2) Between 2004 and 2008, compared to the pre-accession period:}

a) the rate of economic emigration from Latvia substantially increased due to the introduction of free movement of labour within the European Union, decreasing migration costs and social network effect

b) migration flows redirected, to a large extent, towards the United Kingdom, Ireland and Sweden

c) the proportion of tertiary-educated persons among emigrants decreased and is now lower than their proportion in the [adult] population of Latvia

d) the proportion of non-Latvians (especially non-citizens) among emigrants declined

In addition:

e) in the second half of the period, the intensity of emigration declined due to strong economic growth in Latvia.

It is worth noting that hypotheses (a), (b) and (e) have been confirmed in previous studies (Hazans, 2009; Hazans and Philips, 2010; Brucker et al., 2009) and are also supported by the data shown in Table 4.3 of this chapter. Hypotheses (c) and (d) have been confirmed earlier (using Latvian LFS data) with respect to guest workers who worked abroad while still being considered as household members in Latvia (Hazans, 2009, pp. 9, 14; Hazans and Philips, 2010, Figures 3 and 11); here we will provide broader evidence. The relative decline in the emigration of tertiary-educated Latvians is reflected also in the decreasing share of Latvian-born university graduates in OECD countries from $42 \%$ in 2000 to $40.6 \%$ in $2005 / 06$ (OECD, 2012, p. 244).

Another important feature of this emigration wave (which could not be predicted based on theoretical considerations alone) is its mixed nature: while migration was to a large extent short-term and/or cyclical (Krišjāne et al., 2007; Hazans and Philips, 2010), there was a steady growth in the number of Latvians staying long enough abroad to be captured in statistics and considered in expert estimates of diaspora size. 


\section{Crisis-driven emigration (2009-11): Lost jobs and lost hopes}

The economic crisis which began at the end of 2008, in a short time left a segment of Latvian population jobless (see Figures 4.1 and 4.6 for employment and unemployment developments; Figure 4.6 illustrates emigration response to growing unemployment).

Figure 4.6. Unemployment and emigration developments in Latvia, 2002-12

Thousands

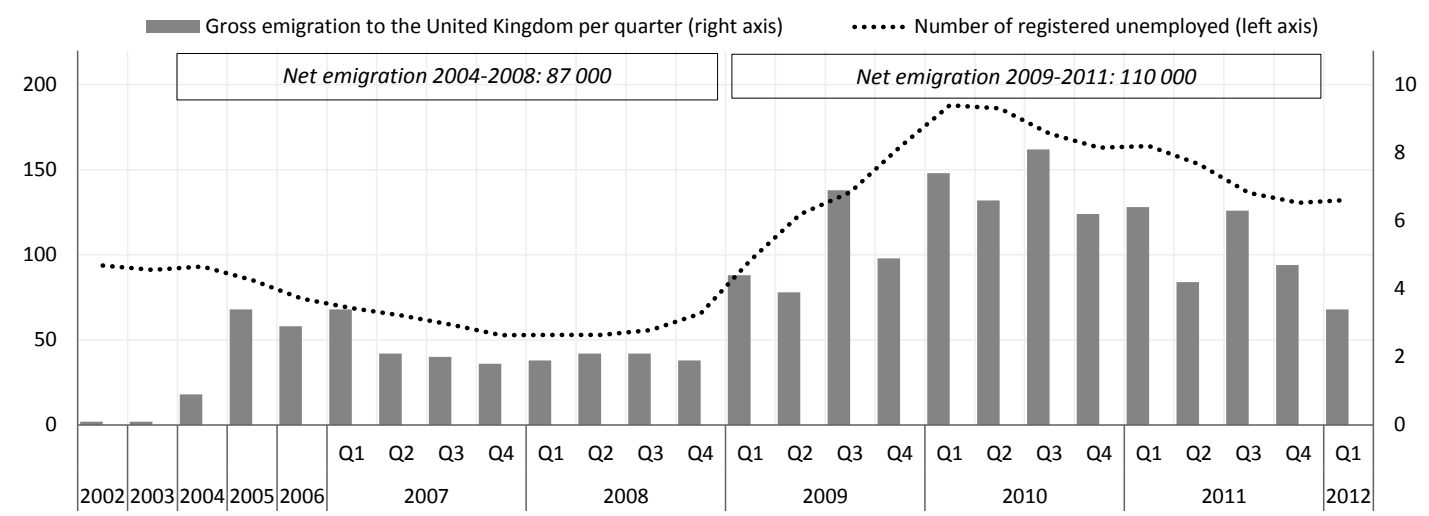

Source: Department of Work and Pensions (United Kingdom), Latvian State Employment Agency, Eurostat.

In the second quarter of 2008 , slightly more than $6 \%$ of economically active males and females were jobseekers. A year later, this rate more than tripled among males and more than doubled among females. By the end of 2009, the unemployment rate had reached $25 \%$ among males and $16 \%$ among females. ${ }^{10}$ Only one out of three jobseekers received unemployment benefits. Benefit recipients with less than 20 years of social insurance record (which was the case for most potential emigrants) faced the prospect of benefit reduction to just LVL 40 (EUR 57) per month. Those who were lucky enough to keep their jobs experienced wage cuts: median real earnings from all jobs fell by nearly 25\% during 2009 and stayed at this level at least until June of 2012 (Figure 4.7). The psychological shock was no less painful: a large proportion of people of working age (including those who managed to keep their jobs) lost confidence in the future.

Figure 4.7. Total monthly gross earnings from all legal jobs for employed population with non-zero earnings

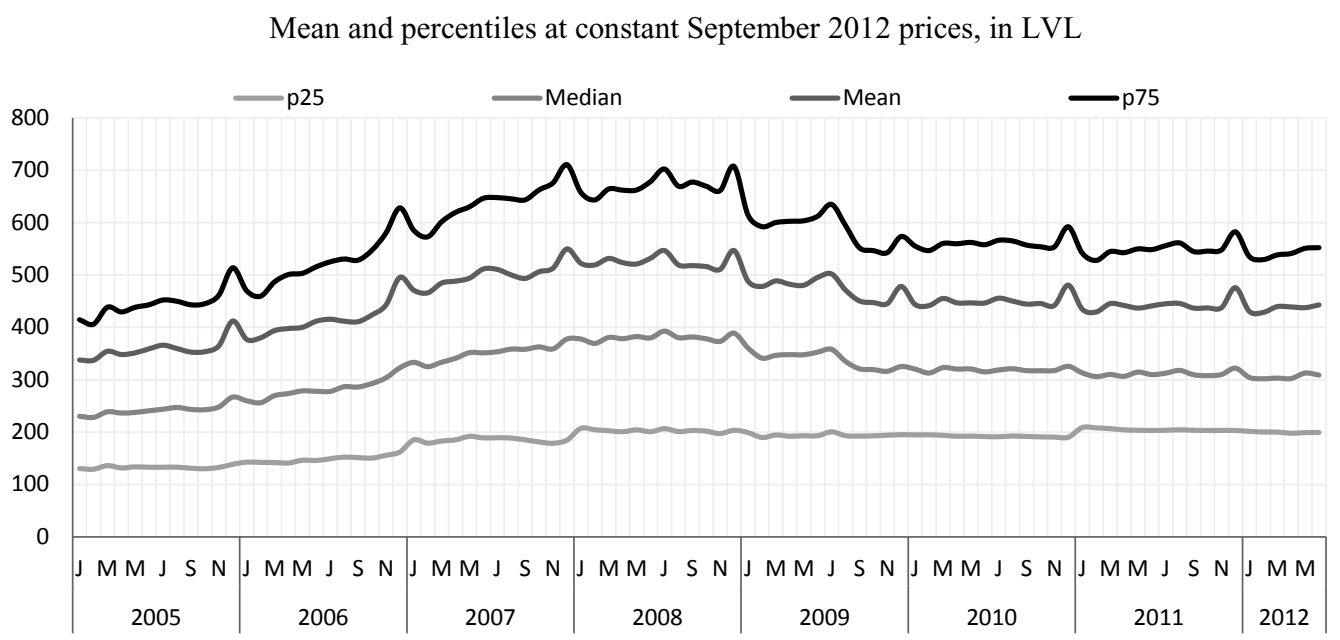

Source: Author's calculations based on data from the State Social Insurance Agency. 
In order to assess the propensity to emigrate by socio-economic group, let us look at the differences in employment and unemployment rates depending on ethnicity, citizenship and education before and during the crisis (Table 4.5). Unemployment, a strong push factor, increased particularly among individuals having no higher education (and even more so among those having no secondary education), as well as for nonLatvians, especially those without Latvian citizenship.

Despite the crisis, finding a job in Western Europe was possible, although not as easy as before (hence, the role of diasporas and informal networks increased). The rate of unemployment was very low ( 3 to $4 \%$ ) in Norway, the Netherlands and Austria, and remained modest (about 8\%) in the United Kingdom, Germany, Sweden, Denmark and Finland (European Commission, 2010, Table 24). During 2009-10, the job vacancy rate (i.e. the number of vacancies relative to the sum of vacancies and occupied posts) in these countries was five to eight times higher than in Latvia (European Commission, 2010, Chart 6). Moreover, across Old Europe nominal earnings continued to rise, while real earnings did not decline (European Commission, 2011, graphs I.1.8 and III.A3.5). Thus, expected gains from emigration in terms of employment and earnings are higher than they were during the pre-crisis period.

Table 4.5. Employment and unemployment rates in the working-age population, by educational attainment, ethnicity and citizenship, 2008-11

Population aged 15-64

\begin{tabular}{|c|c|c|c|c|c|c|c|}
\hline & & \multicolumn{3}{|c|}{ Educational attainment } & \multicolumn{3}{|c|}{ Ethnicity and citizenship } \\
\hline & & Tertiary & Secondary & $\begin{array}{c}\text { Below } \\
\text { secondary }\end{array}$ & Latvian & $\begin{array}{l}\text { Minority } \\
\text { (Latvian } \\
\text { citizens) }\end{array}$ & $\begin{array}{c}\text { Minority } \\
\text { (other) }\end{array}$ \\
\hline \multirow{4}{*}{ Employment $^{1}$} & 2008 & 86.9 & 74.5 & 37.1 & 68.8 & 68.3 & 69.1 \\
\hline & 2009 & 82.3 & 64.6 & 29.4 & 62.4 & 60.4 & 57.4 \\
\hline & 2010 & 80.6 & 61.5 & 28.4 & 61.4 & 57.1 & 54.7 \\
\hline & 2011 & 83.4 & 62.4 & 29.0 & 63.0 & 57.0 & 57.8 \\
\hline \multirow{4}{*}{ Unemployment $^{2}$} & 2008 & 4.2 & 7.7 & 14.6 & 6.5 & 8.8 & 11.3 \\
\hline & 2009 & 8.4 & 18.7 & 31.4 & 15.3 & 18.2 & 23.6 \\
\hline & 2010 & 10.5 & 20.4 & 32.3 & 16.2 & 21.5 & 26.2 \\
\hline & 2011 & 7.3 & 18.5 & 30.0 & 13.4 & 20.9 & 22.1 \\
\hline
\end{tabular}

1. Employment rate is defined as the proportion of the population (in a particular age group) that is employed.

2. Unemployment rate is defined as the proportion of the economically active population (in a particular age group) that is seeking a job.

Source: Author's calculations based on data from the Latvian Labour Force Survey.

The issue of social protection, previously neglected by the middle class, has gained importance. In contrast with the United Kingdom, Ireland, the Nordic countries, Germany and the Netherlands - where a worker with a sufficient contribution record and earnings between $67 \%$ and $100 \%$ of the average, receives (in benefits) about $70 \%$ of previous net earnings even in the case of long-term unemployment - in Latvia, after only nine months of unemployment (or even six, depending on contribution record - and, indirectly, age), the income replacement rate is about $40 \%$ even once social assistance and housing benefits, if any, are accounted for (European Commission, 2011, graph II.2.4). Moreover, Latvian child benefits (LVL 8, or EUR 11.5 per month) are negligible in comparison with 
those paid, for every child younger than 16 years, in Old Europe (e.g. EUR 140 per month in Ireland and GBP 20.3/GBP 13.4 per week for the first/next child in the United Kingdom). ${ }^{11}$

The above factors converged to make emigration a real option in the minds of Latvian residents, even those who had not considered such a possibility before. This category consists of two groups: i) individuals who are inherently not very mobile but did not see another way out of trouble; and ii) persons who were not satisfied with the developments in Latvia and with their own prospects here. In the latter group, one can expect to find a higher-than-average proportion of university graduates, because people who have opted to invest in higher education are usually future-oriented. As far as the propensity to emigrate among persons with less than secondary education is concerned, the direction of change is theoretically ambiguous a priori. On the one hand, representatives of this group suffered more than others from crisis-related unemployment (see Table 4.5); on the other hand, in times of crisis, it would have been difficult for them to compete with secondary school graduates for jobs abroad (one of the reasons being poor language skills).

There are two reasons why one should expect ethnic non-Latvians to be overrepresented among the post-crisis emigrants (in fact, among both of the above mentioned groups). First, the proportion of workers who lost their jobs during the crisis was higher among non-Latvians (Hazans, 2010, Table 1), resulting in the re-emergence of a significant ethnic employment gap, especially wide among university graduates (Hazans, 2010, Figures 6 and 7; see also Table 3.5 above). Second, in July 2009 (despite objections by employers' associations), the government adopted new regulations on state language proficiency requirements, which substantially expanded the list of occupations (both in private and public sectors), which require certified intermediate or advanced Latvian language skills. Given that the previous regulations were perceived by most workers (Latvians and non-Latvians alike) as adequate or in some cases even too strict (Hazans, 2010, pp. 151-153), non-Latvians saw this as a measure undermining the labour market position of minority workers and, in a wider context, signalling the radicalisation of language policies. Such a signal of course works as an additional push factor increasing the inclination to emigrate among non-Latvians. Taking into account that the EU provisions for free mobility of labour do not apply to those who are not citizens, one should expect the largest increase in the propensity to emigrate among non-Latvians holding Latvian citizenship.

To sum up, in the beginning of 2009 one could expect (as formulated in Hazans, 2009) an intensification of emigration, as well as changes in both reasons for emigration and migrant population profile:

\section{(H3) In 2009-2010, compared to the pre-crisis period:}

a) the intensity of emigration from Latvia increased

b) migration flows have further diversified; with a decline in the share of Ireland, heavily hit by the crisis, and an increase in the shares of other (also non-European) destinations

c) the role of push factors in shaping migration flows increased (especially unemployment and wage cuts, but also lack of prospects, loss of hope and uncertainty of Latvia's development path); among pull factors, the role of destination countries' social protection systems increased 
d) migrants are much more oriented towards long-term or permanent emigration and are more likely to move as entire families

e) the proportion of tertiary-educated individuals among emigrants increased significantly, exceeding the corresponding proportion among those who stayed

f) the proportion of individuals oriented towards self-employment or opening their own business among emigrants increased

g) the proportion of ethnic minorities (especially those holding Latvian citizenship) among emigrants increased.

Note that evidence supporting points (a) and (b) is presented in Figure 4.4. Point (d) and the part of (c) related to social security are supported by an interesting account of the changes in the profile of potential emigrants from Latvia (EURES clients) based on the daily records of EURES consultants summarised by Žanna Ribakova, former EURES manager in Latvia, and presented in Table 4.6.

Table 4.6. Changes in the profile of EURES clients in Latvia, 2004-10

\begin{tabular}{l|l}
\hline \multicolumn{1}{c|}{$2004-07$} & \multicolumn{1}{c}{$2008-10$} \\
\hline Planning to move alone & Planning to move with family \\
Looking for temporary, low-skilled job & Looking for permanent, skilled job \\
Minimal knowledge of foreign languages & Better knowledge of foreign languages, higher qualifications \\
Planning to return & Interested in legal employment and social security \\
\hline
\end{tabular}

Source: Ribakova, Z. (2009), "EURES - An Instrument for Facilitating Free Movement of Labour with 15 Years of Experience in European Employment Services", Presentation at the State Employment Agency conference.

\section{Changes in the emigrant population profile, 2000-10}

Table 4.7 presents the statistical portrait of adult emigrants at the end of 2010. The portrait is based on data from a representative population survey - the National Identity: Place, Capability, Migration (NIPCM) survey - in which Latvian residents were asked about their family members and close relatives who left Latvia in 2000-10 (and were living abroad during the survey). The population of emigrants is divided into three groups by period of departure.

For the sake of comparison, Table 4.7 presents two additional population profiles - the profile of a non-migrant - a Latvian resident (as at March 2011), as derived from the 2011 population census, and the profile of a return migrant (a person who, during the past decade, lived abroad for three or more months at a time). Data for the latter profile is based on the NIPCM survey. According to the same survey, return migrants accounted for about $10 \%$ of the population aged 18-74. While our definition of return migrant also includes individuals who have not spent a sufficiently long time abroad to be included in partner countries' population or migration statistics, the same three-month threshold has been used for identifying return migrants in many surveys, including the Eurobarometer (March-April 2010). Note also that while in the literature the term "non-migrant" or "stayer" often excludes return migrants (see e.g. Hazans, 2011b), column "All" in Table 4.7 refers to the entire resident population. 
Table 4.7. Emigrant and general population profiles

\begin{tabular}{|c|c|c|c|c|c|c|c|}
\hline & \multicolumn{4}{|c|}{ Emigrants (by year of departure) } & \multicolumn{3}{|c|}{ Latvian population, March 2011} \\
\hline & \multicolumn{4}{|c|}{$\%$ distribution $^{1}$} & \multicolumn{3}{|c|}{$\%$ distribution $^{2}$} \\
\hline & \multirow[b]{2}{*}{$2000-03$} & \multirow[b]{2}{*}{ 2004-08 } & \multirow[b]{2}{*}{$2009-10$} & \multirow[b]{2}{*}{$2000-10$} & \multicolumn{2}{|c|}{ All } & \multirow{2}{*}{$\begin{array}{c}\text { Return } \\
\text { migrants }\end{array}$} \\
\hline & & & & & Age-adjusted $^{4}$ & Aged 18-74 & \\
\hline Males & 46.5 & 45.2 & 39.9 & 42.8 & 49.1 & 46.5 & 61.3 \\
\hline Females & 53.5 & 54.9 & 60.1 & 57.2 & 50.8 & 53.5 & 38.7 \\
\hline \multicolumn{8}{|l|}{ Age } \\
\hline $18-24$ & 6.9 & 23.4 & 32.7 & 22.6 & 22.6 & 13.7 & 20 \\
\hline $25-34$ & 54.3 & 48.1 & 38.8 & 44.9 & 44.9 & 18.3 & 37.6 \\
\hline $35-44$ & 29.7 & 18.3 & 17.9 & 19.6 & 19.6 & 18.3 & 22.8 \\
\hline $45-54$ & 7.2 & 8.3 & 9.3 & 8.5 & 8.5 & 19.5 & 12.8 \\
\hline \multicolumn{8}{|l|}{ Educational attainment } \\
\hline Below secondary & 5.3 & 5.4 & 4.6 & 6.0 & 21.0 & 21.0 & 11.6 \\
\hline Secondary & 53.8 & 70.6 & 59.9 & 61.8 & 51.9 & 54.2 & 70.2 \\
\hline Tertiary & 32 & 21.5 & 27 & 24.2 & 27.1 & 24.8 & 18.1 \\
\hline Unknown & 8.9 & 2.5 & 8.6 & 8 & 0 & 0 & 0 \\
\hline \multicolumn{8}{|l|}{ Main occupation } \\
\hline Wage earner & 55.2 & 84.8 & 79.9 & 78.3 & 54.5 & 47.7 & 59.4 \\
\hline Self-employed or employer & 0.0 & 1.8 & 3.6 & 2.1 & 6.0 & 5.9 & 6.2 \\
\hline Student & 1.7 & 6.2 & 5.7 & 5.0 & 10.3 & 5.6 & 6.6 \\
\hline Unemployed & 0.0 & 0.6 & 1.5 & 0.9 & 14.7 & 12.4 & 16.9 \\
\hline Other or n.a. ${ }^{5}$ & 43.1 & 6.7 & 9.3 & 13.7 & 14.5 & 28.4 & 10.9 \\
\hline Number of observations & 57 & 215 & 144 & 471 & 1880 & 000 & 89 \\
\hline
\end{tabular}

1. The distribution of emigrants is based on information provided by their close relatives in Latvia in the framework of the NIPCM survey commissioned by the Faculty of Social Sciences, University of Latvia and conducted between December 2010 and January 2011 by the SKDS public opinion research centre. For $12 \%$ of emigrants, year of departure is unknown; these emigrants have been included in the 2000-10 column, and are not shown separately.

2. Population census results (Statistics Latvia, 2012c) and author's calculations.

3. Return migrants - persons who, between 2000 and 2010, spent three months or more abroad at a time but were living in Latvia during the survey. Their profile is derived from the NIPCM survey (see Note 1 above).

4. Using the emigrant population (2000-10) as standard.

5. "Other" include housekeepers, pensioners and other economically inactive persons; "n.a." refers only to emigrants.

Source: Author's calculations based on NIPCM survey and Statistics Latvia.

\section{Gender and age structure}

According to the NIPCM survey (Table 4.7), women accounted for $57 \%$ of adult emigrants who left Latvia during the first decade of the $21^{\text {st }}$ century, as compared to $51 \%$ among similarly aged non-migrants and only $39 \%$ among returnees. Similarly, according to demographic data from other EU countries, the proportion of females among Latvian citizens residing abroad is $57 \%$. Foreign data also confirm that the share of females among those returning to Latvia is smaller than among those leaving Latvia for these countries. This suggests that male emigrants are more likely to return than their female counterparts. The gender imbalance among emigrants puts the reproductive potential of the Latvian population at risk. A much greater risk for Latvia's demographic prospects 
however, is associated with the age structure of the emigrant population. By the end of 2010, two thirds of emigrants were younger than 35 (at departure, this proportion is at least three quarters). This is more than twice as high as the share of this age-group among non-migrants. Persons aged 35-44 are proportionally represented among emigrants, while just one out of ten emigrants is older than 54 years. Return migrants are, on average, slightly older than emigrants but much younger than non-migrants.

\section{Educational attainment}

By the end of 2010, 24\% of emigrants were university graduates; this was similar to the proportion among residents aged 18-74 (25\%) but somewhat lower than among residents of the same age distribution as emigrants (27\%). Among emigrants who left during the crisis, however, $27 \%$ have higher education. The share of universityeducated individuals among economically active post-enlargement working-age emigrants (24\%) is slightly higher than the corresponding figure among all EU10 emigrants in EU countries (22\%, see European Commission, 2012, p. 272), but the difference is not statistically significant. The proportion of individuals with a low level of education among emigrants is between $6 \%$ and $14 \%$, and is probably closer to the latter, since those $8 \%$ of emigrants whose relatives were unaware of their educational attainment, are less likely to have had a high level of education. Given that $21 \%$ of the resident population lacks secondary education, emigrants, especially the most recent ones, appear to be better educated. Among return migrants, both the lowereducated and the university graduates are under-represented in comparison with the general population, while $70 \%$ hold secondary education. The share of university graduates among returnees $(18 \%)$ is lower than among emigrants, suggesting that emigrants with higher education are less likely to return; Hazans (2012, Figure 5) supports this hypothesis using Latvian LFS data.

When the share of university graduates is compared across the three waves of emigration, a U-shaped curve emerges $(32 \%-21 \%-27 \%)$, which is consistent with hypotheses (H1)-(a), (H2)-(c) and (H3)-(e) above, regarding the propensity to emigrate among tertiary-educated residents of Latvia. This becomes even more obvious when only emigrants aged 22 or older are considered (note that this group includes all but two tertiary-educated emigrants in our sample): among pre-accession emigrants, the proportion of university graduates is $31 \%$, in the post-accession period this proportion falls to $24 \%$, but then rises again to reach $32 \%$ among those who left Latvia in 2009-10 (Figure 4.8).

Figure 4.8 also presents differences between the educational profiles of emigrants depending on their ethnicity, citizenship and the country of destination. The largest proportion of university graduates is found among non-Latvians holding Latvian citizenship. This is well in line with two already mentioned circumstances: a relatively low employment rate among tertiary-educated non-Latvians and restrictions faced by Latvian non-citizens in EU labour markets. When emigrants in different destination countries are compared, the lowest proportion of university graduates is found in Ireland. 


\section{Figure 4.8. Educational attainment among emigrants from Latvia aged 22 and over by period of departure,} ethnicity, citizenship and destination

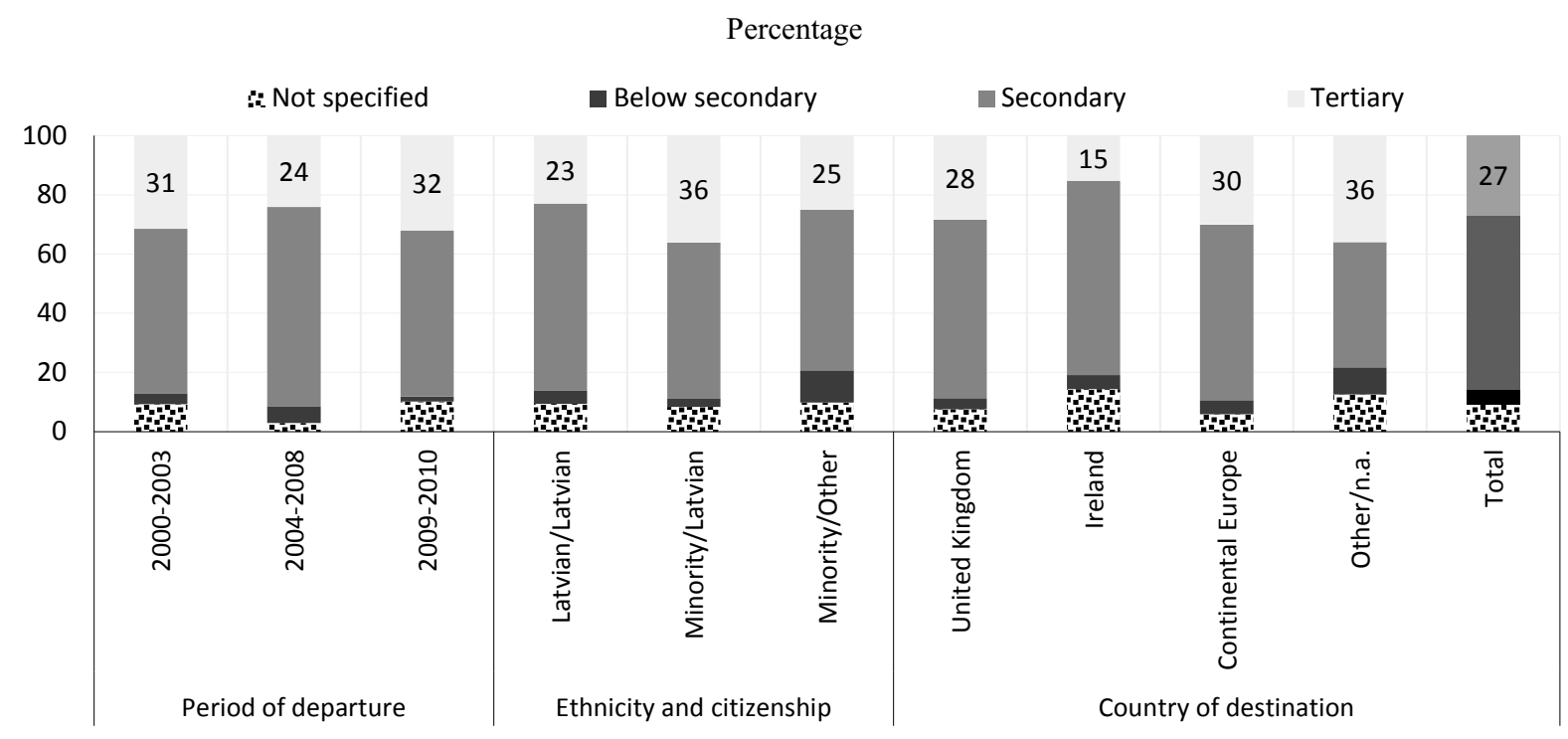

Note: Educational attainment - the highest level of education completed by the end of 2010; Ethnicity and citizenship are proxied by attributes of the emigrant's relative who provided the information.

Source: Author's calculations based on data from NIPCM.

\section{Labour market status and occupation}

A striking feature of the emigrants' situation in the host countries' labour markets is an extremely high employment rate: at least $87 \%$ among those who left Latvia in 2004-08 and at least $84 \%$ among crisis-period emigrants. ${ }^{12}$ For the sake of comparison, only $54 \%$ of non-migrants aged 18-74 were employed in March of 2011, while the age-adjusted rate of employment for non-migrants was $61 \%$. Unfortunately, the rate of employment among emigrants who left Latvia before 2004 could not be calculated with any degree of certainty due to the high percentage of missing values $(43 \%)$, but it is surely higher than among non-migrants. Note that return migrants in Latvia also feature a higher employment rate (about $66 \%$ ) than stayers. On the other hand, they also feature a higher unemployment rate, but this might be because they can afford to search longer due to savings from earnings abroad (Hazans, 2008).

The proportion of self-employed and entrepreneurs among crisis-period emigrants doubled in comparison with the previous period, confirming hypothesis $(H 3)-(f)$.

Even under the most radical (and unlikely) assumption that all emigrants with an "unknown" employment status were in fact unemployed, emigrants of the last two waves feature a much lower unemployment level than the one observed in Latvia during the crisis. To sum up, emigrants' labour market outcomes are significantly better than those of non-migrants.

Figure 4.9 provides a more detailed breakdown of Latvian emigrants' main activities abroad (by education, destination country and period of departure from Latvia). On average, only $26 \%$ of emigrants held a paid job in which they used their qualifications (education). This proportion is higher (and the incidence of brain waste smaller) in continental EU15 countries, where it reaches $36 \%$, than in other countries of destination. 
The lowest rate (19\%) is found among emigrants living in Ireland and in countries outside Old Europe (United States, Canada, the Russian Federation, Ukraine, etc.). Tertiaryeducated emigrants are more likely to use their qualification than those with a secondary education or less. Those who emigrated during the crisis were less choosy with respect to their job abroad: only $23 \%$ of them use their qualification, whereas this is the case for $29 \%$ of emigrants who left Latvia during the previous two waves of migration (the difference is statistically significant).

Figure 4.9. Emigrants' main activity abroad at the end of 2010, by educational attainment, destination and period of departure from Latvia

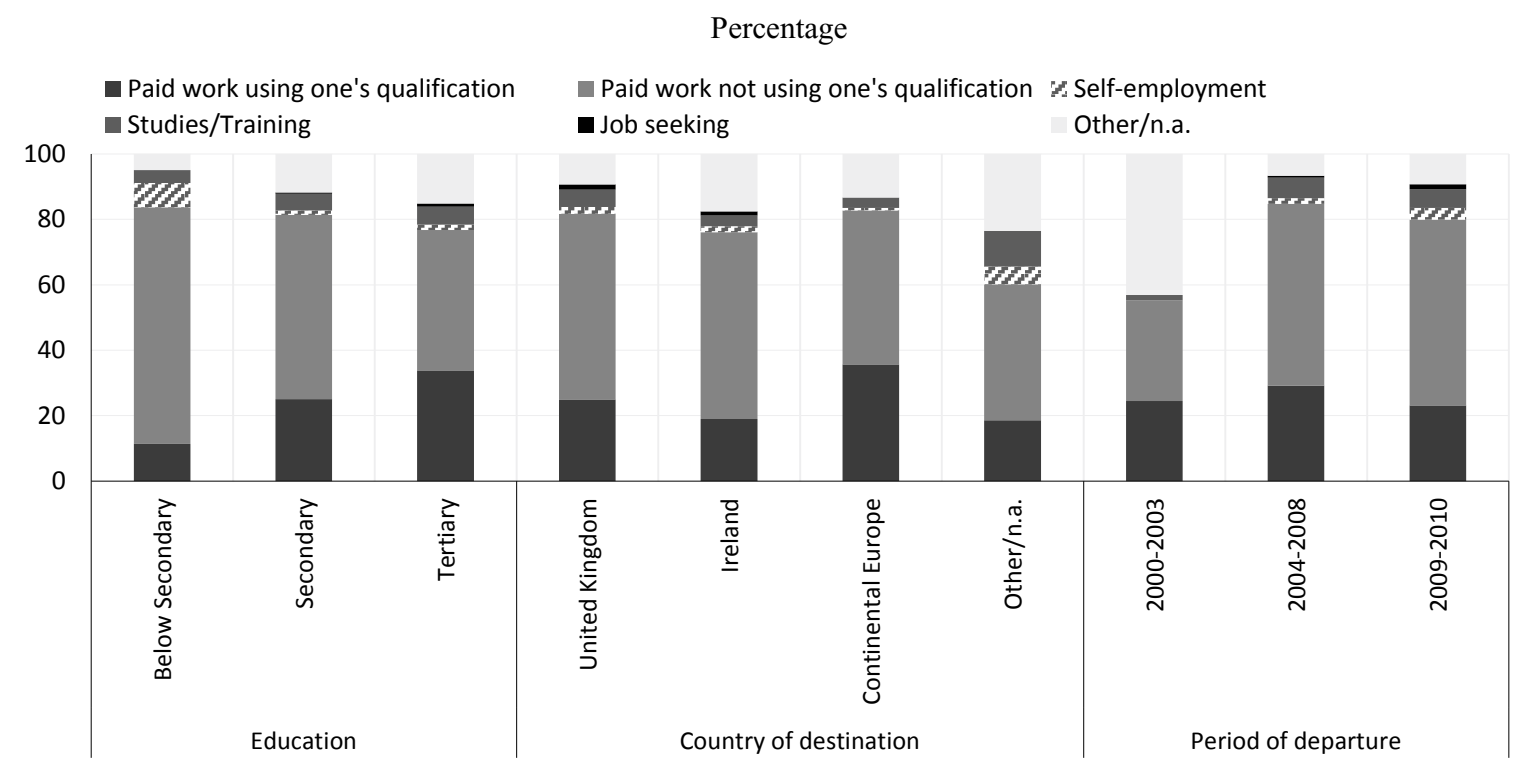

Note: "Continental Europe" refers to the EU15 (without the United Kingdom and Ireland), Norway and Switzerland.

Source: Author's calculations based on data from NIPCM.

\section{Will the emigrants ever come back?}

Given Latvia's deteriorating demographic situation, the possible return of emigrants can be extremely important. Figure 4.10 summarises information on Latvian emigrants' intentions to return, as reported in the NIPCM survey. On average, $8 \%$ of emigrants intend to (or would like to) return within six months, while about $20 \%$ of emigrants entertain the possibility of returning within five years. A more recent survey of users of the Latvian social network Draugiem.lv residing in the United Kingdom, Ireland, Germany, Norway and Sweden produced a similar result: only $23 \%$ of respondents plan to return to Latvia within the next five years, $65 \%$ plan to stay abroad longer than five years, and $12 \%$ plan to move to another country (Krišjāne et al., 2012). These findings are in striking contrast with the situation observed in 2005-06, when two-thirds of emigrants having left Latvia in 2004-05 were planning to return within two years, most of them (almost half of all emigrants) even within one year (Hazans and Philips, 2010, Figure 9). In fact, in 2002-07, more than half of Latvian guest-workers ${ }^{13}$ returned home within one year, according to the Latvian LFS (Hazans, 2009, p. 19; Hazans and Philips, 2010, Figure 10). These data support hypothesis (H3)-(d) namely that Latvian emigrants who left during the crisis are to a much larger extent oriented towards long-term or permanent emigration. 
Ethnicity and citizenship are also associated with intentions to return, with non-Latvians having no Latvian citizenship show the lowest propensity to return: only $8 \%$ within five years (Figure 4.10). Tertiary- and secondary-educated Latvian emigrants are more likely to return than their counterparts who do not have a secondary education. When different destination countries are compared, it appears that Latvian emigrants in Ireland have the lowest propensity to return within five years (Figure 4.10).

The proportion of emigrants intending to return sharply declines as the duration of stay abroad increases. Thus, among those who left Latvia less than a year ago, one-fifth plan to return within six months, and more than one-third contemplate return within five years. By comparison, these proportions fall to $3 \%$ and $15 \%$, respectively, among emigrants who stayed abroad between three and five years.

Figure 4.10. Intentions to return within six months and within five years, among emigrants from Latvia, by ethnicity and citizenship, educational attainment, destination and duration of stay abroad, 2010-11

\section{Percentage}

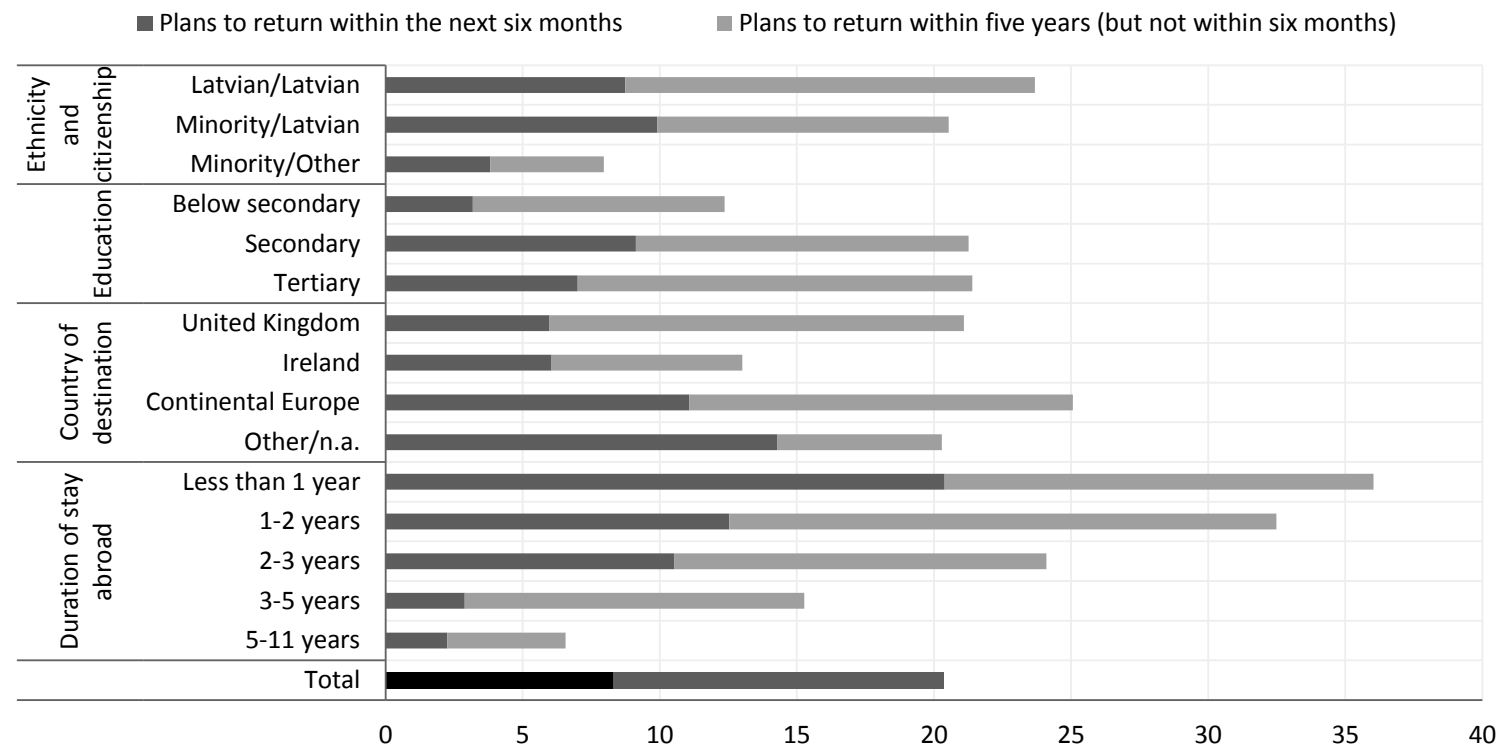

Source: Author's calculations based on data from NIPCM, December 2010 to January 2011.

\section{Migration networks and the experience of return migrants}

As shown in Hazans (2011b, Box 2.25), among those aged 18-65, the proportion of individuals who had some relative or friend with foreign work experience reached $75 \%$ as early as the end of 2005 and increased to $82 \%$ by the beginning of 2011 . Both at the end of 2006 and in the middle of 2008, 15\% of working-age individuals were able to obtain information about work abroad from recent (of the last two years) experience, either their own or that of a close relative. Moreover, at the end of $2010,28 \%$ of respondents indicated that some of their close relatives were working abroad (i.e., during the survey), and $10 \%$ had personal foreign work experience (including $9 \%$ during the last five years).

These data confirm the emergence of powerful migration networks. This, as noted above, significantly reduces information and job search costs, as well as psychic and adaptation costs for potential emigrants. Another (possibly, even more important) 
conclusion from these data is that in recent years, work abroad has become an integral part of Latvian national identity.

Let us now look at how return migrants assess their experience abroad. The NIPCM survey (December 2010-January 2011) identified 89 respondents who spent at least three months abroad (in a single visit) during the last ten years, but have returned to Latvia. Figure 4.11 presents information on the impact of this experience on various aspects of their lives (health, family, etc.), according to their own assessment. Generally speaking, migrants seem to view their experience abroad as having affected their lives favourably.

A majority of respondents were of the opinion that the time spent outside of Latvia had a positive effect on their lives in terms of health $(60 \%)$, relationships with family members $(82 \%)$, material well-being (73\%; only $8 \%$ reported a negative impact) and self-confidence $(82 \%)$.

Figure 4.11. Return migrants' assessment of the impact of their time spent abroad on various aspects of their lives

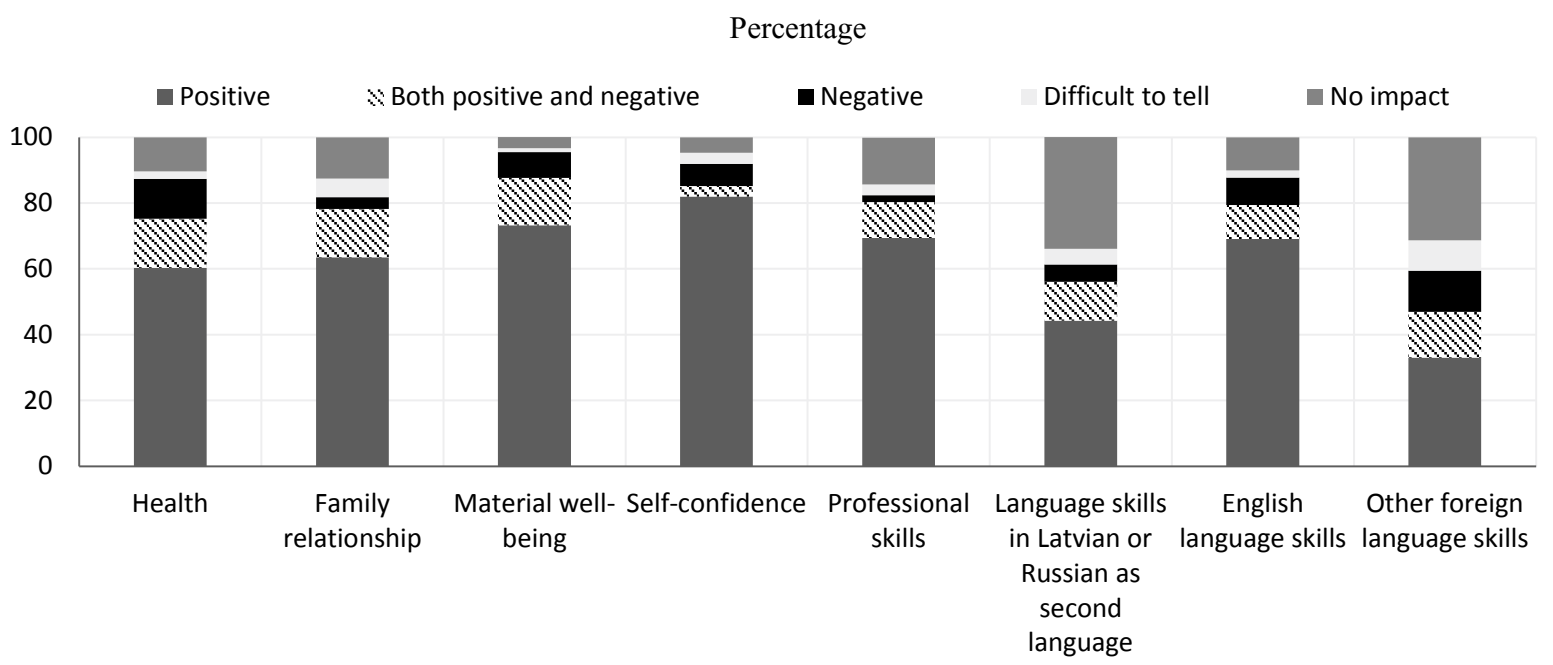

Source: Author's calculations based on data from NIPCM.

Respondents were also asked to assess the effect of their stay outside of Latvia on their professional skills. Again, most (69\%) considered the experience to have affected their lives positively in this respect (Figure 4.11). The effect of time spent abroad on language skills in Latvian or Russian as second language is less pronounced but very interesting. $44 \%$ of respondents reported a positive effect, one-third noticed no effect, while a negative assessment was very rare (Figure 4.11). As could be expected, most respondents (69\%) felt that their English language skills had improved.

With respect to other foreign languages, a perceived negative effect of time spent abroad is more common (13\%) than in the case of English, yet a perceived positive effect prevails (33\%).

Return migrants have higher employment levels than people without a migration background. An econometric analysis (omitted here), however, showed that this association can be accounted for by differences in the age and gender distributions of the two groups. 
Figure 4.12 sheds some light on the question of whether foreign work experience helps to earn more in Latvia. For this purpose, we look at the personal net income of individuals employed in Latvia in the second half of 2010, depending on their (and their family members') post-accession foreign work experience. Among those respondents who did not have family members working abroad during the survey, those who had personal work experience abroad have, on average, an 18\% higher income than those without such experience (LVL 306 vs. LVL 261 per month). On the other hand, among respondents who did have a family member working abroad during the survey (and, therefore, were likely to receive remittances), return migrants' average income exceeds the average income of individuals without recent foreign work experience by $25 \%$ (LVL 383 vs. LVL 306 per month). Comparing median rather than average income of these groups does not change the results qualitatively. Econometric analysis (details omitted) confirms that even after controlling for educational attainment, age, gender, region and family members working abroad, employed return migrants collect a $13 \%$ higher income than their employed counterparts without post-accession foreign work experience. Moreover, this difference is due to experience abroad rather than to differences in productivity between return migrants and other workers. A study based on 2007 data yielded similar results (Hazans, 2008).

To sum up, both the respondents' opinions and their labour market outcomes suggest that the effect of foreign work experience on various aspects of the lives of return migrants has been largely positive.

Figure 4.12. Personal net income of individuals employed in Latvia in the second half of 2010, by their own and their family members' foreign work experience

LVL per month

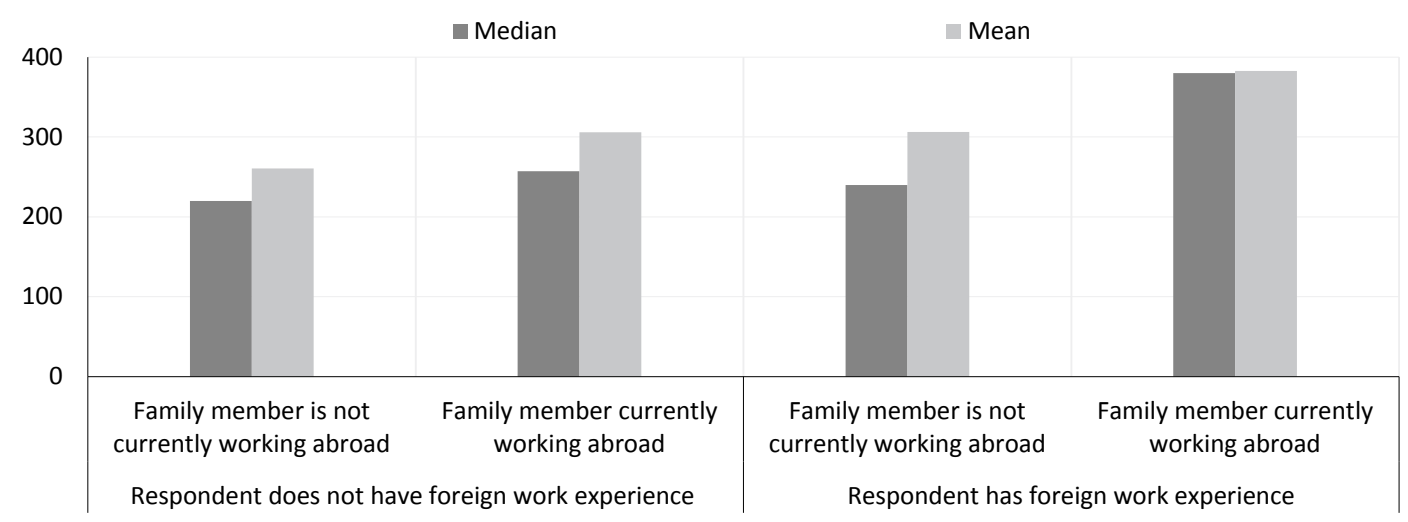

Source: Author's calculations based on data from NIPCM.

\section{Intentions to emigrate}

This section explores emigration intentions of Latvian residents aged 18-65 in the period between December 2010 and February 2011, after more than two years of recession, accompanied by a powerful wave of emigration. The results, based on two surveys, are broken down by respondents' level of education, main occupation (status), ethnicity, citizenship, region, type of settlement and a background of migration.

The NIPCM survey asks whether the respondent plans to move from Latvia in the near future in order to improve material well-being for themselves or their families. 
Those who answered "Yes" or "I do not exclude such a possibility" are categorised as potential emigrants; the former group is further referred to as having concrete plans.

To analyse reasons for emigration, we used the "DnB NORD Latvian Barometer survey No. 35" conducted in February 2011 (DnB NORD), which sampled from the same reference group (Latvian residents aged 18-75) as the NIPCM survey. The DnB NORD survey asked "Do you plan to live and work abroad?", followed, in the case of a positive answer, by a multiple choice question in which the respondent was asked to specify one or more reasons from a given list. We divided potential emigrants into two categories. The first one includes those who mention one of the following economic reasons (no jobs available in Latvia; no possibility to earn a living in Latvia; elsewhere one can earn much more; better social protection abroad), possibly together with one or more other (non-economic) reasons. The second category includes those who did not mention any of the economic reasons, but plan emigration only for non-economic reasons - namely, one or more of the following: an opportunity to see the world, to get new impressions, to meet new friends; education and career possibilities; no future in Latvia; does not like what is going on in Latvia; does not like the political environment; wants to live in a stable country; influence of other people.

Overall, in December 2010-January 2011, 9\% of the population aged 18 to 65 planned to leave Latvia in the near future to improve their material well-being and another $17 \%$ did not exclude such a possibility. Potential emigrants (both groups) thus constituted 26\% of the population. In February 2011, in the framework of the DnB NORD survey, $20 \%$ of respondents reported plans to emigrate for economic reasons, and another $10 \%$ only for non-economic reasons, thus raising the proportion of potential movers to about $30 \%$ (note however, that in this case, plans do not necessarily refer to the near future and are not restricted to emigration for economic reasons).

According to the NIPCM survey, the highest propensity to emigrate in the near future is found among those with a secondary education: $28 \%$ of them are potential movers, including 10\% with concrete plans. The other two groups are not far behind, however: $25 \%$ of those with less than secondary education and $22 \%$ of the tertiary-educated are potential emigrants, in both cases including 7\% with concrete plans (Figure 4.13, top).

Larger differences are observed with respect to reasons for emigration (Figure 4.13, bottom). The proportion of those who plan to move abroad for economic (and possibly other) reasons decreases with educational attainment: from $29 \%$ among respondents with a basic education to $13 \%$ among university graduates. By contrast, the proportion of those who plan emigration only for non-economic reasons increases from $8 \%$ among respondents with less than secondary education to $14 \%$ among respondents with tertiary education.

From an occupational perspective, the highest propensity to emigrate in the near future is found among students: more than half of them are potential emigrants, including $18 \%$ with concrete plans (Figure 4.13, top). A lower, yet significant propensity to emigrate is found among the unemployed, manual workers and non-manual workers, with between $23 \%$ and $30 \%$ potential emigrants, including $7 \%$ to $12 \%$ with concrete plans (Figure 4.13 , top). On average, one-third of potential movers mention only non-economic reasons for emigration. The only occupational group in which most potential movers do not mention any economic reasons for their plans, is that of non-manual workers (Figure 4.13, bottom). 
Figure 4.13. Intentions to emigrate among Latvian residents aged 18-65, by educational attainment and main occupation, December 2010 to February 2011

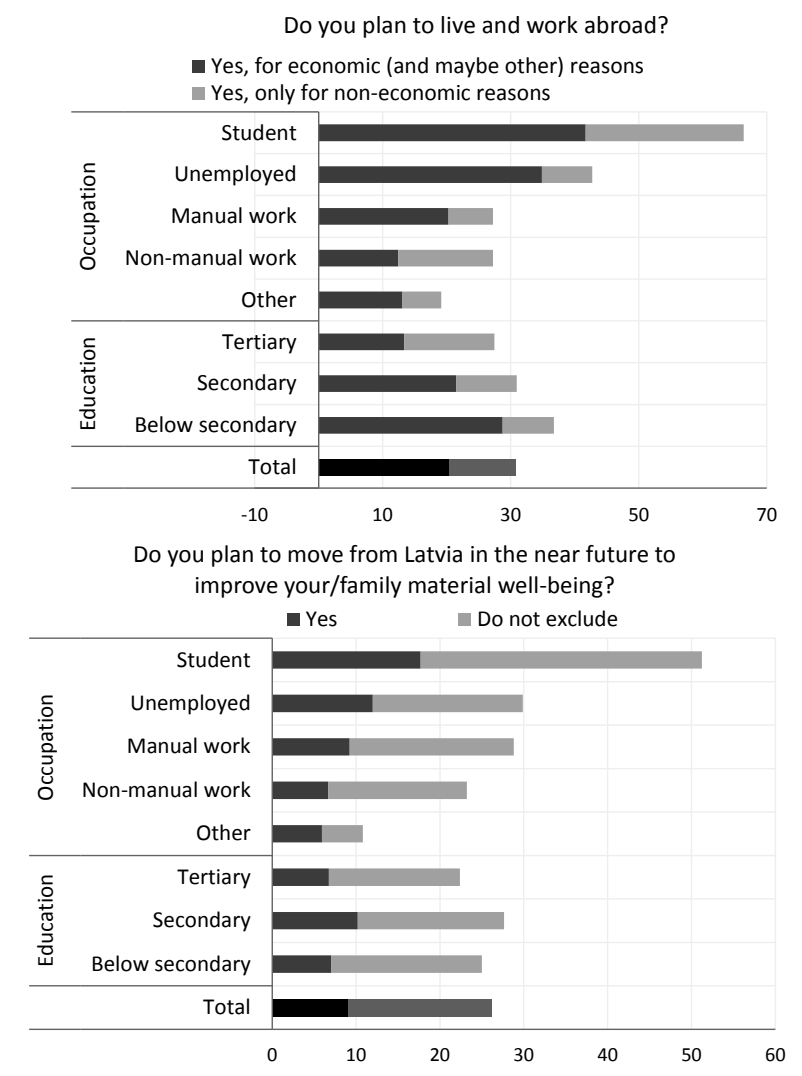

Source: Author's calculations based on survey data: top - "DnB NORD Latvian Barometer", No. 35; bottom - NIPCM.

Noteworthy is the very high propensity to emigrate (37\% overall, including almost $9 \%$ with concrete plans) among persons who did not complete their higher education and who are not students (this result is not shown in Figure 4.13).

The unemployed are more often inclined to leave Latvia due to economic, or a combination of economic and non-economic reasons (this is the case for $35 \%$ of all jobseekers), than for non-economic reasons alone (8\%). A similar situation is found among manual workers ( $20 \%$ and $7 \%$, respectively). Among non-manual workers, on the other hand, $15 \%$ plan to leave Latvia only for non-economic reasons, while $12 \%$ mention economic reasons. Interestingly, total emigration potential is equally large (27\%) among both manual and non-manual workers (Figure 4.13, bottom).

In order to gain a more in-depth understanding of the motivations and concreteness of intentions to emigrate in various population groups, we used an econometric model, which evaluates the impact on the individual's emigration plans, of each of the following variables: gender, age, family status, educational attainment, ethnicity and citizenship, main occupation, region and degree of urbanisation, while holding all other variables constant. The main results of this analysis - presented as the mathematical difference, in percentage points, between the adjusted proportion of potential emigrants in each category and that in the reference category - are summarised in Table 4.8. 
Other things being equal, females and males without under-age children do not differ much in terms of propensity to emigrate, although the probability of an emigration plan in the near future is 2.6 percentage points higher for a female than for an otherwise similar male. By contrast, when a woman with children is compared to an otherwise similar man with children, the probability for the woman to plan emigration in the near future or in general is 5.5 to 6 percentage points lower, and her probability to plan emigration for economic reasons 9 percentage points lower, while probability to plan emigration due to non-economic reasons alone is 3 percentage points higher. ${ }^{14}$

The presence of children in the family significantly increases males' propensity to emigrate due to economic reasons, while for females this effect is negative with respect to plans for the near future but is not significant with respect to emigration in general or due only to non-economic reasons (note that for females, the effect of the presence of children in each of the five columns of Table 4.8 can be obtained by summing the rows "Lives with children" and "Female with children"). This supports hypothesis (H3)-(d) namely, that since the onset of the economic crisis, potential emigrants are oriented towards longterm or permanent emigration and tend to move as entire families.

While intentions to emigrate vary significantly by age group, it is worth noting that the 25-34 year-olds have practically as strong a propensity to emigrate as those aged 18 to 24 . For both groups, the probability of a plan to emigrate in the near future is 23 percentage points higher than for 55-65 year-olds, the probability of a more general plan to emigrate (without specifying the time) 30 to 35 percentage points higher, and the probability of a plan to emigrate due to economic reasons 26 to 34 percentage points higher. For population aged 35 to 44 years, all the above probabilities are 6 to 11 percentage points lower than for the 25-34 year-olds, but for those aged 45-54 years, another 6 to 10 percentage points lower. When the average probability for each model is taken into account (see row "Proportion of positive answers" in Table 4.8), it appears that the strongest age effects, which exceed the average prevalence of emigration plans by a factor of two-and-a-half, are related to concrete plans to move abroad in the near future.

It is worth noting, that the highest propensity to emigrate due to non-economic reasons alone, is found in 25-44 year-olds.

When other factors are controlled for, the difference between persons with secondary and tertiary education with respect to propensity to emigrate becomes insignificant, with the exception of emigration due only to non-economic reasons. In the latter case, university graduates feature a 4.3 percentage points higher probability of contemplating emigration. These findings once again support our hypothesis (H3)-(e) regarding a significant increase in the proportion of individuals with higher education among emigrants during the crisis. On the other hand, for a person whose education is below secondary, the probability of a plan for [economic] emigration in the near future is 6 to 7 percentage points lower than for an otherwise similar person having completed secondary education. This is despite the fact that people of low educational attainment suffered more than others from recession-related lay-offs (see Table 4.5). 
Table 4.8. Impact of demographic and occupational factors on emigration plans, population aged 18-65, December 2010-February $2011^{1}$

Mathematical difference between proportions of potential emigrants as compared to reference category, in percentage points

\begin{tabular}{|c|c|c|c|c|c|c|}
\hline & & \multicolumn{2}{|c|}{$\begin{array}{c}\text { Do you plan to move from Latvia in } \\
\text { the near future to improve your/family } \\
\text { material well-being? }\end{array}$} & \multicolumn{3}{|c|}{ Do you plan to live and work abroad? } \\
\hline & & \multirow[b]{2}{*}{ Yes } & \multirow[b]{2}{*}{ Yes or do not exclude } & Yes & Yes & Yes \\
\hline & & & & for any reason & $\begin{array}{l}\text { for economic } \\
\text { (and possibly also } \\
\text { other) reasons }\end{array}$ & $\begin{array}{l}\text { for non-economic } \\
\text { reasons alone }\end{array}$ \\
\hline \multicolumn{2}{|c|}{ Proportion of positive answers } & $9 \%$ & $26 \%$ & $31 \%$ & $20 \%$ & $10 \%$ \\
\hline \multicolumn{7}{|c|}{ Factors $^{1,2}$} \\
\hline \multirow[t]{5}{*}{ Gender and family } & Male without children & Ref. & Ref. & Ref. & Ref. & Ref. \\
\hline & Female & $2.6^{* *}$ & -3 & -1.2 & 0.7 & -1.5 \\
\hline & Married or lives with a partner & 1.3 & $-7.0^{* * *}$ & -2.6 & -0.7 & -2.9 \\
\hline & Lives with children & $3.6^{* *}$ & $8.0 * * *$ & 4.6 & $7.8^{* * *}$ & -3.6 \\
\hline & Female with children & $-8.1 * * *$ & $-6.4 *$ & $-5.1 *$ & $-9.6 * * *$ & $4.9 * *$ \\
\hline \multirow[t]{5}{*}{ Age } & $18-24$ & $22.9 * * *$ & $33.0 * * *$ & $34.5^{* * *}$ & $33.4^{* * *}$ & 2.2 \\
\hline & $25-34$ & $23.0^{* * *}$ & $32.4^{* * *}$ & $30.4^{* * *}$ & $25.6^{* * *}$ & $8.0^{* *}$ \\
\hline & $35-44$ & $17.0^{* * *}$ & $20.9 * * *$ & $22.8^{* * *}$ & $19.2^{* * *}$ & $6.3^{* *}$ \\
\hline & $45-54$ & $11.4^{* * *}$ & $14.1 * * *$ & $13.2^{* * *}$ & $13.2^{* * *}$ & 2.6 \\
\hline & $55-65$ & Ref. & Ref. & Ref. & Ref. & Ref. \\
\hline \multirow[t]{3}{*}{ Education } & Below secondary & $-6.0 * * *$ & $-7.1^{* *}$ & -3.4 & -1.9 & -1.9 \\
\hline & Secondary & Ref. & Ref. & Ref. & Ref. & Ref. \\
\hline & Tertiary & -2.7 & -2.5 & 2.3 & -3 & $4.3^{* * *}$ \\
\hline \multirow[t]{3}{*}{ Ethnicity \& citizenship } & Latvian & Ref. & Ref. & Ref. & Ref. & Ref. \\
\hline & Non-Latvian, Latvia citizen & -2 & $7.3^{* * *}$ & $7.4^{* * *}$ & $8.3^{* * *}$ & -0.5 \\
\hline & Non-Latvian, non-citizen & $2.6^{*}$ & 2.4 & 0.9 & $6.7^{* *}$ & $-6.4^{* * *}$ \\
\hline \multirow[t]{4}{*}{ Main occupation } & Wage earners & Ref. & Ref. & Ref. & Ref. & Ref. \\
\hline & Unemployed & $4.8^{* * *}$ & $6.0^{* *}$ & $14.9 * * *$ & $14.3^{* * *}$ & -1.1 \\
\hline & Student & 1.7 & 6.8 & $19.4^{* * *}$ & 6.3 & $11.1^{* * *}$ \\
\hline & Other & 1.1 & $-10.7 * * *$ & 1.4 & 2 & -0.8 \\
\hline Monthly household & Up to 80 & $5.4^{* *}$ & -1.9 & -2.3 & $-5.1^{*}$ & 3.2 \\
\hline income per capita, & $81-120$ & $4.3^{* *}$ & 1.8 & 1.5 & -4.5 & $8.0 * * *$ \\
\hline \multirow[t]{4}{*}{ LVL } & $121-160$ & Ref. & Ref. & Ref. & Ref. & Ref. \\
\hline & $161-200$ & 3.3 & 1.8 & -1.1 & $-8.8 * * *$ & $9.3^{* * *}$ \\
\hline & $>200$ & 1.3 & -3.3 & -4.4 & $-7.8^{* *}$ & $5.2^{* *}$ \\
\hline & Unspecified & $4.3^{*}$ & -0.3 & 0.5 & $-9.3^{* * *}$ & $11.2^{* * *}$ \\
\hline $\begin{array}{l}\text { Other controls } \\
\text { (region and } \\
\text { urbanisation level) }\end{array}$ & \multicolumn{6}{|c|}{5 regions and 3 urbanisation levels (indicator variables) } \\
\hline $\begin{array}{l}\text { Number of } \\
\text { observations }\end{array}$ & & 869 & 869 & 868 & 868 & 868 \\
\hline
\end{tabular}

Note: $*, * * * * *$ - estimates significantly different from zero at the $10 \%, 5 \%, 1 \%$ levels, respectively.

1. Factors and reference categories are given in bold. Cells report the mathematical difference, in percentage points, between the adjusted proportion of potential emigrants in each category and that in the reference category.

Source: Author's calculations based on survey data: the first two columns are based on "DnB NORD Latvian Barometer", No. 35; the last three columns, on the NIPCM 2010 survey.

After controlling for the above variables, Non-Latvians with Latvian citizenship are 7 to 8 percentage points more likely than ethnic Latvians, to plan or consider moving abroad ("in the near future", "in general" and "for economic reasons"). On the other hand, non-Latvians without Latvian citizenship are not significantly different from ethnic Latvians with respect to the first two of the above-mentioned probabilities (i.e., "in the near future" and "overall"). The probability of planning emigration due to economic reasons among non-citizens, however, is 7 percentage points higher than among ethnic Latvians. This, in turn, is partly offset by a 6 percentage points lower probability of planning emigration due to non-economic reasons alone. Finally, among non-Latvians 
with Latvian citizenship the propensity to move abroad due to non-economic reasons alone is the same as among ethnic Latvians.

While findings reported in the previous paragraph suggest that non-citizens are less inclined to emigrate than non-Latvians with Latvian citizenship, results from the first column of Table 4.8 are slightly different: holding other variables constant, the probability of planning economic emigration in the near future for non-citizens is, on average, 2.5 percentage points higher than for Latvians and 4.5 percentage points higher than for minority citizens. In all likelihood, this is attributable to the difficult labour market situation of non-citizens (see Table 4.5). Overall, the results of the econometric analysis support hypothesis (H3)- $(\mathrm{g})$ above, regarding changes in the role of ethnicity after the onset of the economic crisis: the propensity to emigrate among minority individuals - especially among those holding Latvian citizenship - appears to be higher than among Latvians. Official data on ethnic composition of emigrants in 2011-12 (Statistics Latvia, 2013a) also support this conclusion: estimated proportion of ethnic Latvians among emigrants is below $50 \%$, while their share in general population is about $61 \%$.

As can be expected, the unemployed are much more likely than the employed, to plan emigration ("in the near future", "in general", "for economic reasons").The impressive size of this effect is demonstrated by the fact that the difference in probabilities between the unemployed and employed (respectively, 5, 15 and 14 percentage points), is very large relative to the average proportion of potential emigrants of the given kind (respectively, 9\%, 31\% and 20\%) in population aged 18-65. If those who do not exclude the possibility of moving abroad in the near future are also considered potential emigrants (along with those having specific plans), then the likelihood to belong to this group for an unemployed person is 6 percentage points higher than for an employed person. By contrast, with respect to plans to move abroad only for non-economic reasons, an unemployed person does not differ significantly from an employed individual.

Finally, students are much more oriented towards emigration for non-economic reasons alone, than those whose main activity is work: the difference in probabilities is 11 percentage points, which is a very large effect given that overall just $10 \%$ of population falls into this category.

Results reported so far refer to early 2011 . Figure 4.14 provides evidence from a more recent (August 2012) survey, in which respondents were asked to choose from a list (or to suggest) three main reasons that would cause them to reject an offer to live and work outside Latvia for a long time.

According to this survey, 4\% of respondents aged 18-64 are "determined movers" people who, while ready to move under certain conditions, could not think of a reason which would stop them.

In the same survey, respondents were asked about the main conditions that would need to be met for them to accept an offer to live and work outside Latvia for a long time. Figure 4.15 ranks the most frequent answers. Higher income, better living conditions and (notably) better social policies in the potential country of destination lead the list. Just one out of eight respondents mentioned warranted possibility to return as a precondition. 
Figure 4.14. Main reasons to reject an offer to live and work outside of Latvia for a long time

Proportions of population aged 18-64 who chose each answer

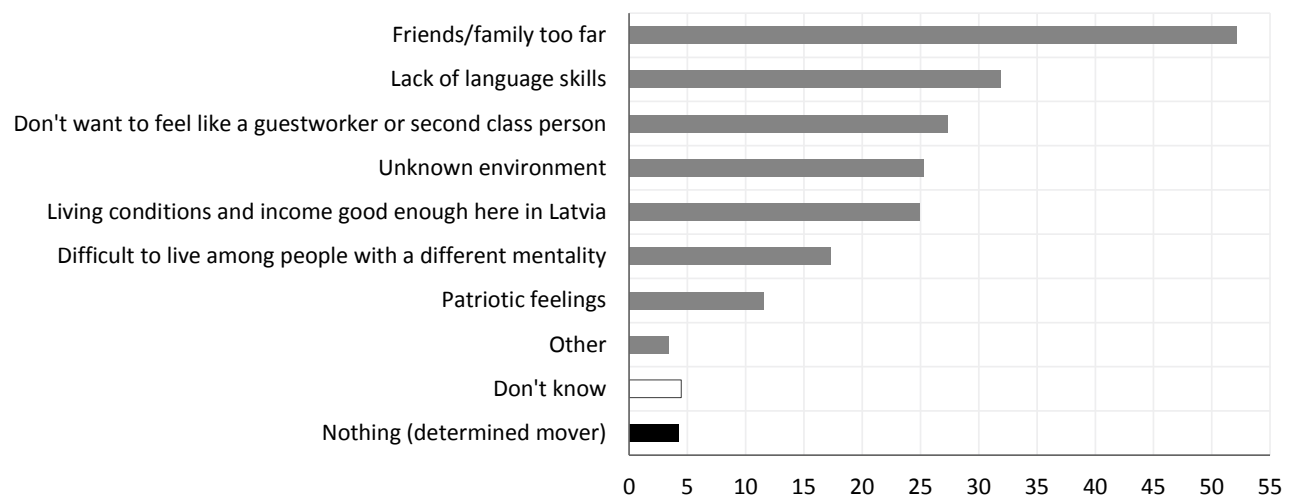

Source: Author's calculations based on data from the "DnB NORD Latvian Barometer", No. 51 (August 2012).

Only $22 \%$ of respondents are "determined non-migrants" - under no conditions would they move abroad.

Questions similar to those reported in Figures 4.14 and 4.15 were asked in another survey conducted by the same agency early in 2010. Figure 4.16 compares the results regarding determined non-migrants (as defined above) and potential emigrants - those who would accept an offer to work and live abroad, at least under certain conditions. ${ }^{15}$ The lists of conditions differed somewhat across years, but in both surveys there was an open-ended option to list "Other conditions". Thus, the results are comparable (although not perfectly). In two and a half years, the share of potential emigrants increased from $54 \%$ to $68 \%$ at the expense of the proportion of determined non-migrants, while the share of the undecided remained at $10 \%$. This suggests that emigration potential has increased - despite the intensive emigration that took place in the period between the two surveys (see Table 4.4), restored economic growth $(5.7 \%$ in the first three quarters of 2012 vs. $-2.4 \%$ in the same period of 2010) and declining (yet high) unemployment (14.2\% in the third quarter of 2012 vs. $20.5 \%$ in the first quarter of 2010 , seasonally adjusted).

Figure 4.15. Main reasons to accept an offer to live and work outside of Latvia for a long time

Proportions of population aged 18-64 who chose each answer

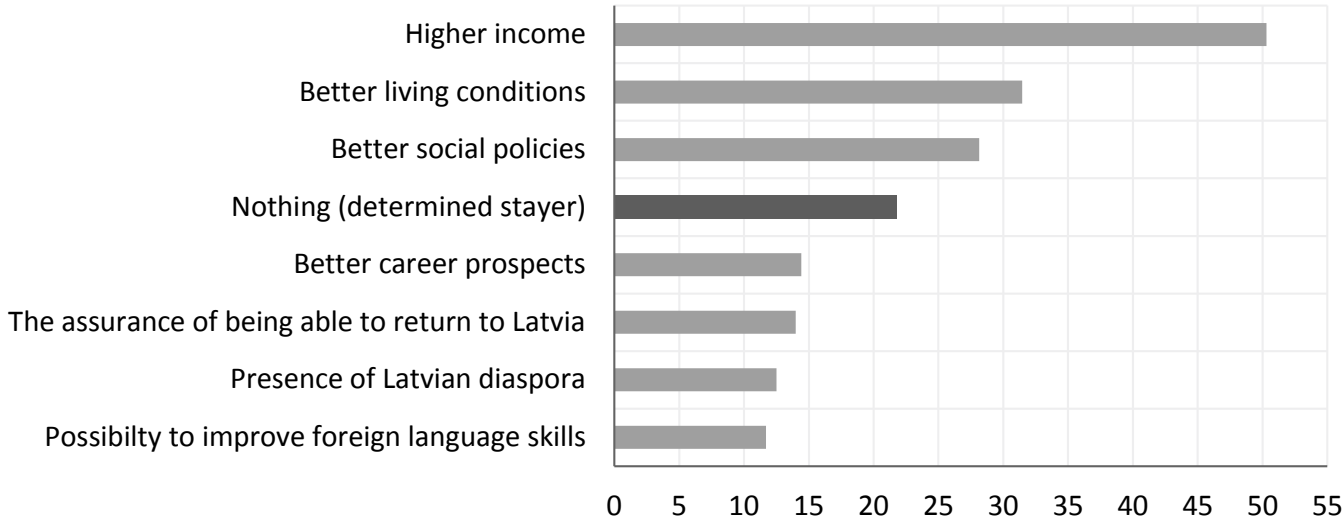

Note: The five least popular answers are not shown.

Source: Author's calculations based on data from the "DnB NORD Latvian Barometer”, No. 51 (August 2012). 
Figure 4.16. Determined stayers and potential emigrants in population aged 18-64

August 2012 vs. February 2010

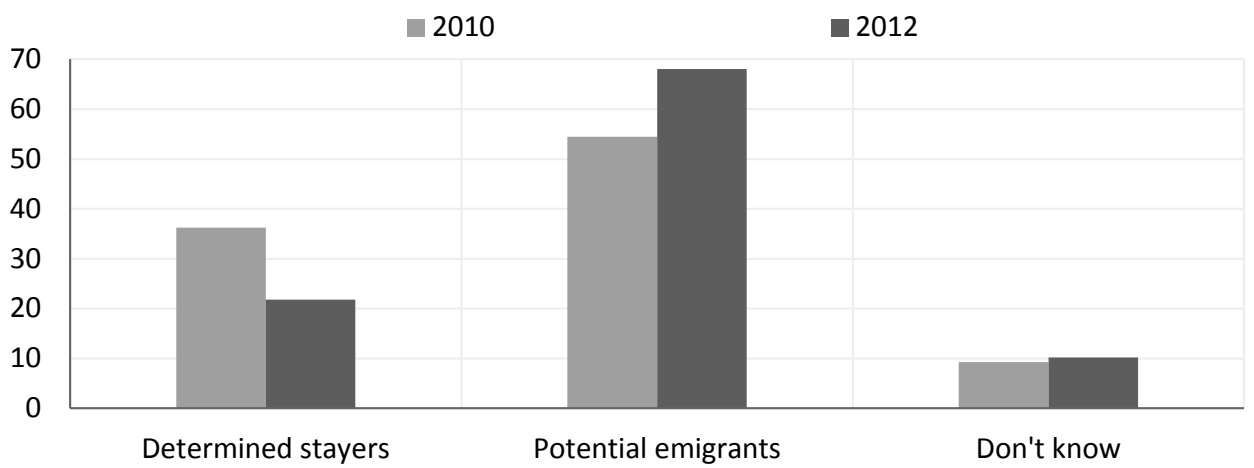

Source: Author's calculations based on data from the "DnB NORD Latvian Barometer", No. 22 and No. 51.

This result is consistent with the increasing importance of non-economic reasons for emigration, or reasons that are economic in nature but rooted in the past rather than linked to current economic trends, such as credit liabilities. Indeed, Krišjāne et al. (2012), based on a survey among users of a Latvian social network residing outside of Latvia, found that debt repayment was the most popular main reason for emigration $(22 \%$ of respondents), followed by uncertainty about one's future (19\%), difficulties in finding a job (17\%) and insufficient career prospects (15\%).

\section{The economic impact of emigration on Latvia}

Emigration may affect the sending country's labour market in a number of ways. First, it tends to reduce unemployment below the levels expected under a zero-emigration scenario, because actual or potential unemployed, and economically inactive individuals move abroad or fill the vacancies left behind by previously employed emigrants. Table 4.9 (based on LFS data) indicates that in 2003-10 one-fifth to one-third of Latvian guestworkers experienced unemployment or economic inactivity in Latvia during the year prior to their departure.

Table 4.9. Unemployment or spells of economic inactivity in Latvia during the year prior to departure, among Latvian guestworkers, ${ }^{1}$ 2003-10

Percentage

\begin{tabular}{lrrrrrrrr}
\hline & 2003 & 2004 & 2005 & 2006 & $2007^{2}$ & $2008^{2}$ & 2009 & $2010^{3}$ \\
\hline Unemployed & 11.9 & 16.0 & 19.9 & 25.5 & 10.3 & 10.0 & 18.7 & 19.0 \\
Inactive & 9.9 & 14.3 & 10.0 & 12.8 & 9.2 & 7.4 & 6.8 & 4.0 \\
Total & 20.8 & 30.4 & 29.0 & 33.4 & 19.5 & 16.5 & 24.0 & 23.0 \\
\hline
\end{tabular}

1. Guestworkers here are labour emigrants still considered household members back home.

2. For 2007-08, the results are not comparable with the other years due to a change in LFS design in 2007.

3. Data for 2010 refer to "one year ago" rather than "during the previous year" and hence should be seen as lower bounds.

Source: Author's calculations based on data from the Latvian Labour Force Survey. 
Moreover, among all emigrants with legal work or registered unemployment experience in Latvia, the share of those whose last registered activity before leaving was unemployment, rose from 10\% in 2005 to $48 \%$ in 2011 (Figure 4.17).

\section{Figure 4.17. Estimated share of registered unemployed among emigrants with registered labour market} experience, and average last monthly amount received in benefits by emigrants before departure, 2005-11

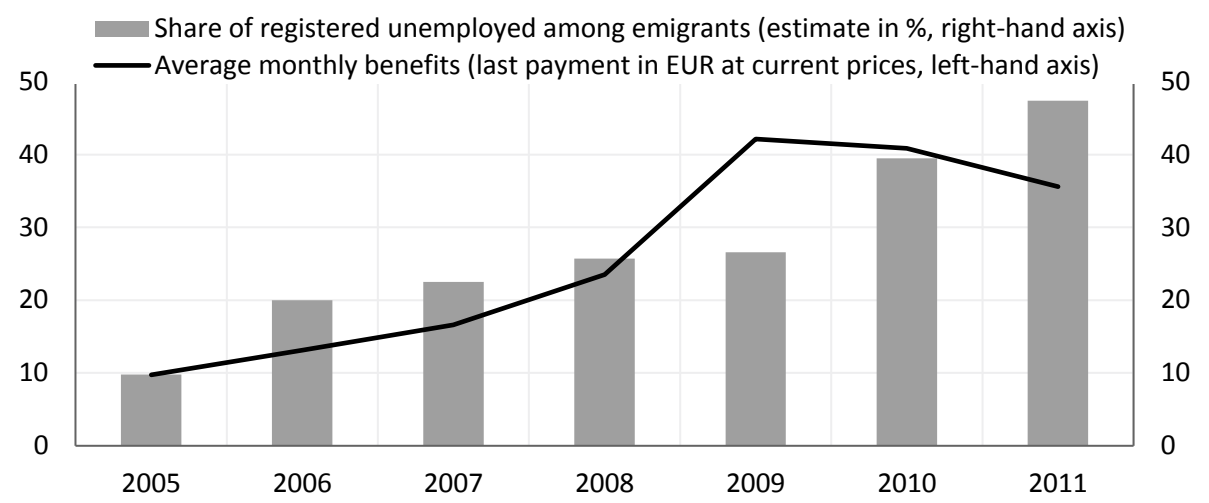

Note: Emigrants' age structure is used for assigning weights to individuals (excluding retirees) permanently leaving both SSIA and SEA datasets in between January 2005 and August 2011 (to allow one year abroad for those who left most recently).

Source: Author's calculations based on data from the State Social Insurance Agency (SSIA) and the State Employment Agency (SEA).

These data suggest that, were it not for emigration, there would have been fewer vacancies, and unemployment would have been much higher, at least in 2009-12, a period in which vacancies were scarce (Figure 4.18). Moreover, emigration led to significant fiscal savings on state and social benefits (Figure 4.17). Note that whether, during a period of intensive emigration, unemployment actually falls and job vacancy rate grows depends on the business cycle. Unemployment was falling in 2004-07, then growing until the first quarter of 2010 and then again falling (Figure 4.6); job vacancy rate "predicted" the coming recession earlier than did unemployment, and resumed growth later (Figure 4.18).

As discussed in detail in Hazans and Philips (2010), during the growth period, emigration was not the only cause for the decline of unemployment. Increase in job vacancy rate (especially in manufacturing and construction, as well as for semi-skilled manual workers) outpaced emigration in 2005-07 (even more so in 2005-06), see Figure 4.18. By contrast, during the jobless recovery of 2010-11, job vacancy rate was either roughly constant at a very low level or growing at a much slower pace than emigration. Moreover, the fastest growth in job vacancy rate refers to high-skilled nonmanual jobs (Figure 4.18). This is consistent with an increasing share of university graduates among the emigrants.

Several studies have used large macro-econometric models to estimate the effect of emigration on the rate of unemployment in sending countries, including Latvia; see Holland et al. (2011) and European Commission (2012, pp. 275-276) for a summary. In particular, Barrel et al. (2007, Tables 3 and 4) estimate that migration contributed to reduce the rate of unemployment in Latvia by 2.4 percentage points over the four-year period of 2005-08. Holland et al. (2011), however, find a much smaller effect. Zasova (2012) developed a model which sets the estimated contribution of emigration to the decline in the non-accelerating inflation rate of unemployment (NAIRU) after EU enlargement, at 0.4 points (applying our emigration estimates). 
Figure 4.18. Net emigration and job vacancy rate, 2005Q1 to $2012 Q 3$

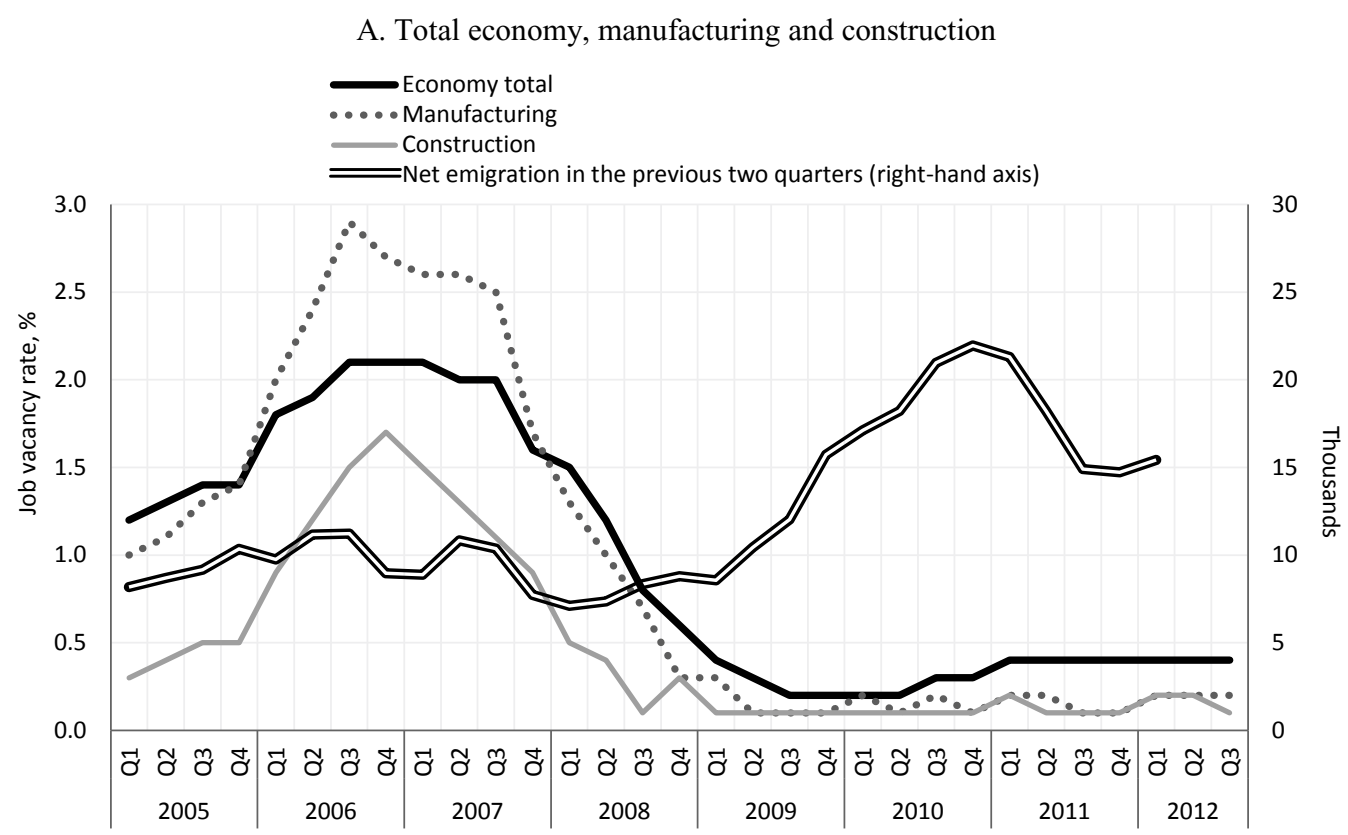

B. Trade, finance $\&$ insurance, and information $\&$ communication

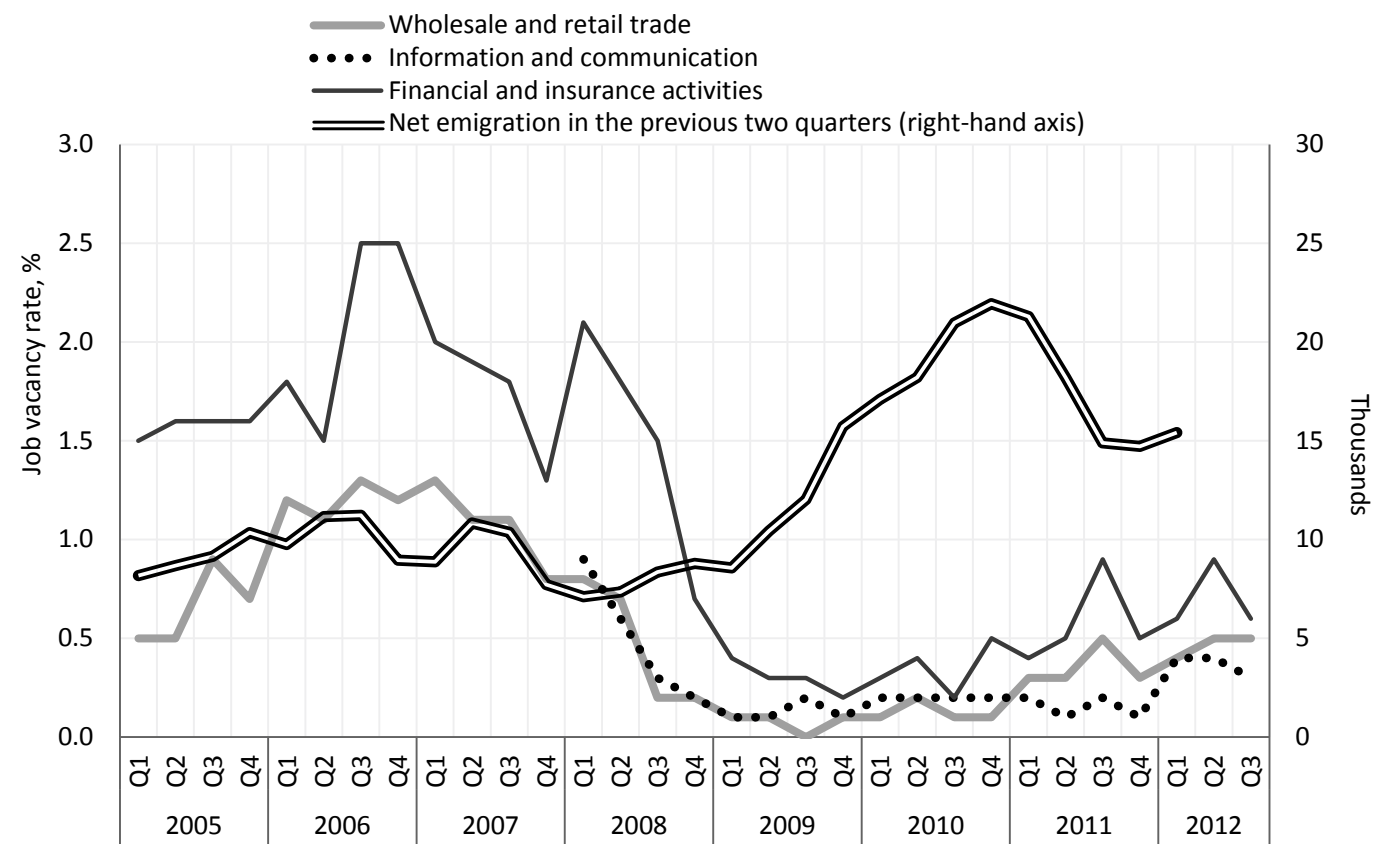


Figure 4.18. Net emigration and job vacancy rate, $2005 \mathrm{Q} 1$ to $2012 \mathrm{Q} 3$ (cont.)

C. Total economy, by occupation

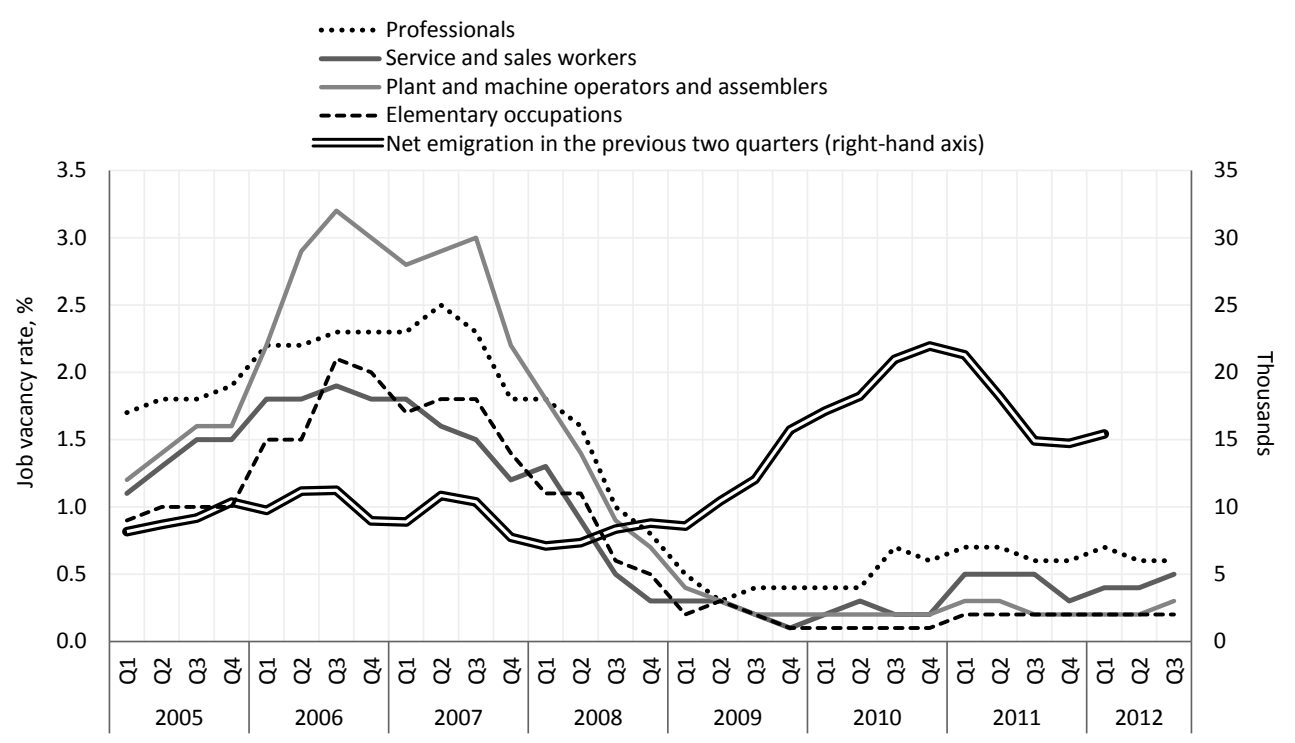

Note: Annual outflows are transformed into quarterly ones assuming the dynamics of social security numbers (NINos) in the United Kingdom.

Source: Vacancy rates from Eurostat and immigration data from Eurostat, OECD, Statistics Latvia, other national statistical offices, Department of Work and Pensions (United Kingdom), Department of Social Protection (Ireland), author's calculation and compilation.

A major focus of public debate in Latvia is the question whether emigration has already led to labour shortages, as it had in 2005-07 (see Hazans and Philips, 2010; and Rutkowski, 2007 for discussion and evidence). Employers and potential investors complain that despite high unemployment they cannot find qualified workers, suggesting that unemployment in Latvia is largely structural. Survey data, however, provide only limited support for these claims. The highest proportion of enterprises reporting labour shortages is found in the construction sector and among large manufacturing firms, but even there it peaks at about $20 \%$ in late 2012, and at any rate remains below $10 \%$ in trade and services (Figure 4.19). A more detailed analysis by Anosova et al. (2012) and Hazans (2013a, 2013b) also seems to refute the hypothesis that Latvian unemployment is structural (i.e. that available unemployed are not suited for most of the vacancies offered). Difficulties in finding relevant employees concern only a small share of businesses and a small proportion of available vacancies. Nevertheless, labour shortages will inevitably become a serious challenge in the near future, seeing that the cohorts of labour market entrants are expected to be smaller than those of leavers (a situation exacerbated by emigration, but that would have occurred in any case).

Increased propensity to emigrate tends to reduce labour supply and make it more elastic, thus increasing real wages and narrowing the gap between the marginal productivity of labour and pay, but also forcing employers to lower hiring standards (for a discussion of the latter point, see Hazans and Philips, 2010). Through real wages, emigration also contributes to increases in consumer prices. At the same time, however, through falling domestic demand, it also exerts influence in the opposite direction. Holland et al. (2011) do not provide estimates for emigration impact on real wage growth in Latvia, while Barrel et al. (2007, Tables 3,4) estimate that over the four-year period of 2005-08 emigration contributed 0.8 percentage points of inflation in Latvia and Lithuania, 
and 0.2 points in Estonia. Figure 4.20 presents estimates of the effect of emigration on real wages in Latvia for the period 2001-10, based on a macro-econometric model developed by Zasova (2012). By 2010, the estimated cumulative effect is an increase of real wages by $2.5 \%$ (compared to a zero-emigration scenario). These estimates seem quite low. The European Commission (2012, p. 276) notes that this might be due to aggregation bias and that the effects for specific skill groups, occupations or sectors might be significantly larger. Hazans and Philips (2010) discuss other reasons why macro-models might underestimate the effect of emigration on real wages: macro-models do not account for the monopsonistic structure of the labour market, in particular the threat of a substantial fall in labour productivity when a firm loses not just a marginal worker but, say, half of its workforce. Scale effect, work organisation problems, and the inability to compete for publicly financed projects can all be underlying factors.

Figure 4.19. Proportion of enterprises reporting a shortage of labour as a limiting factor, by sector, 2010 Q3 to 2013 Q2

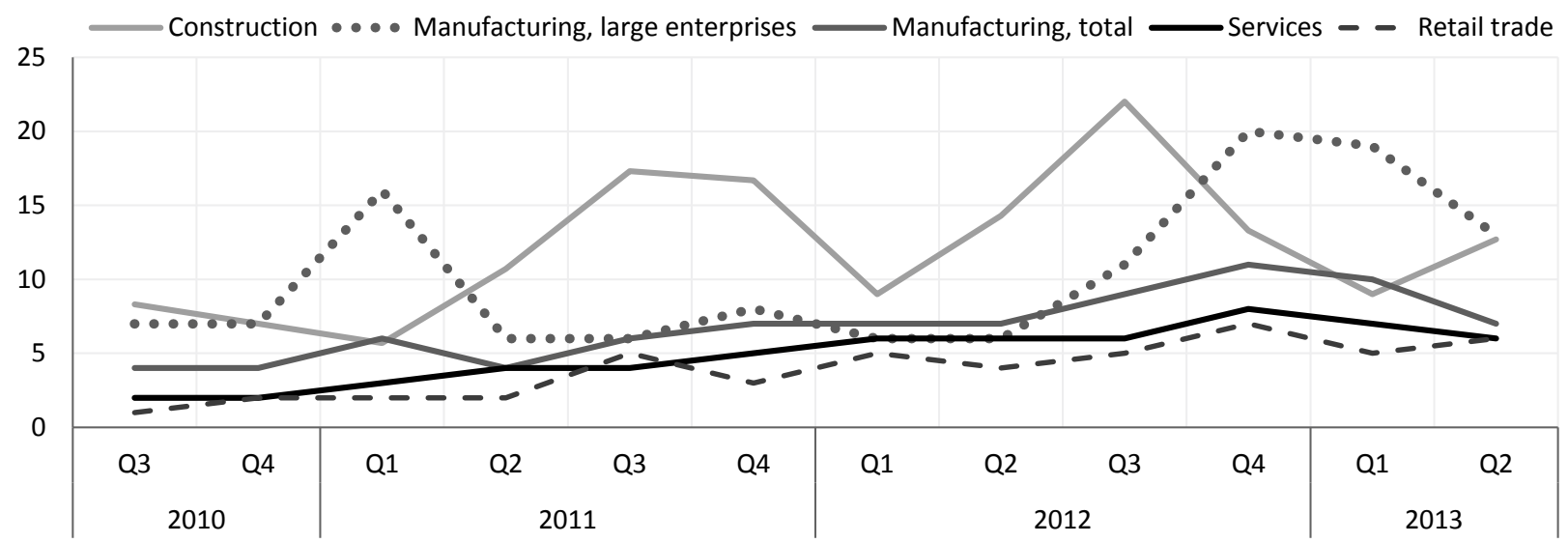

Source: Author's calculations based on surveys of economic sentiment provided by Statistics Latvia.

Figure 4.20. The estimated effect of emigration on real GDP and real wages, 2001-10

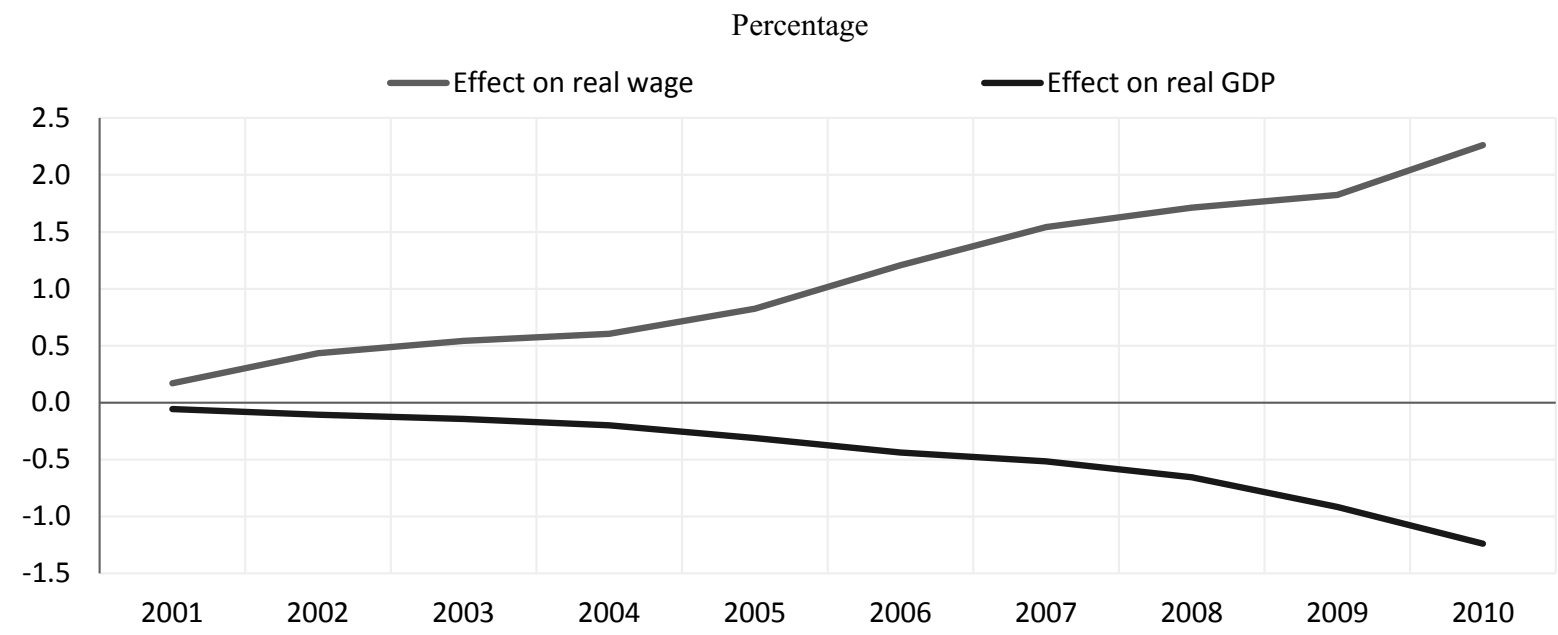

Source: Author's calculations based on macro-econometric model by Zasova, A. (2012), "Econometric Assessment of Performance of Latvian Labour Market”, PhD Thesis, University of Latvia, Riga. 
The overall economic impact of emigration results mainly from a reduction of the labour force. This effect might be reinforced if emigrants are on average more skilled than non-migrants or mitigated if they are less skilled. Emigrants' remittances, on the other hand, can partly or fully compensate the loss of output, but this is unlikely to last forever, especially when emigration becomes increasingly permanent, as in the case of Latvia. For the period of 2004-09, Holland et al. (2011), assuming a net outflow of only $2.5 \%$ of the population (this study focused on outflows to EU15) estimated the long-term effect on Latvian real GDP to be $-3.3 \%$; only half of which has been compensated by remittances during the same period (European Commission, 2012, p. 278). Clearly, the overall long-term effect of losing $9 \%$ of a country's population (and $14 \%$ of its labour force) would be much larger, but estimating it using the same model is beyond the scope of this chapter. A simpler model by Zasova (2012) produced a smaller impact of $-1.5 \%$ (Figure 4.20). On the other hand, introducing the loss of $14 \%$ of the labour force into the production function with the share of labour being 0.64 (as in Krasnopjorovs, 2012b; a number of previous studies arrived to similar estimates), one gets a permanent reduction of 9 percentage points in potential output. ${ }^{16}$

Figure 4.21 suggests that the latter estimate is too high since domestic productivity of at least three quarters of emigrants was below median productivity of all legally employed persons in Latvia. At the same time Figure 4.21 provides strong evidence to support to the hypothesis that during the crisis the emigrants (especially the top half) are relatively much more productive than before, and the brain drain risk is increasing.

Figure 4.21. Estimated mean and percentiles of emigrants' last earnings from all jobs as a proportion of median earnings of all legally employed persons in the same month, 2005-11

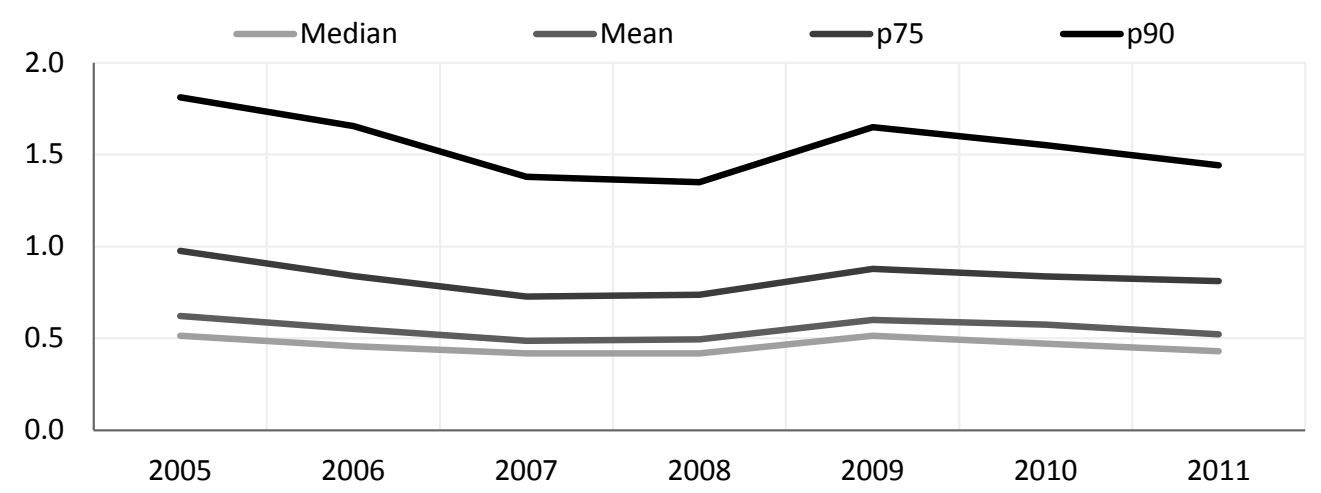

Source: Author's calculations based on data from the State Social Insurance Agency (SSIA) and the State Employment Agency (SEA). Annual ratios shown in the figure are obtained as averages of respective monthly ratios. Emigrants' age structure is used for assigning weights to individuals (excluding retirees) permanently leaving both SSIA and SEA datasets in between January 2005 and August 2011 (to allow one year abroad for those who left most recently).

As noted above, return migrants are on average more productive than non-migrants, but as long as their number is small, this will not be sufficient to compensate for brain drain.

Due to space constraints, we are unable to cover all aspects of the economic impact of migration at length, but let us briefly mention a number of factors not addressed here.

By reducing population and hence domestic market size, emigration discourages investment - both foreign and domestic. This is reinforced by the threat of labour shortages (Kugler and Rapoport, 2005; Javorcik et al., 2011; Gormsen and Pytlikova, 
2012). While theoretical considerations suggest that investment from and trade with countries hosting large numbers of recent emigrants from Latvia should substantially increase, this is yet to happen. Should Latvian diasporas in the United Kingdom, Ireland, Germany, Norway, Sweden, etc. be considered as potential trade partners and foreign direct investment sources?

\section{Conclusion}

The negative demographic effects of emigration on the Latvian economy (and especially on the sustainability of its social security system) suggest the need for measures which would address both causes and consequences of emigration. Direct job creation measures, as well as tax policies stimulating labour demand would address lack of jobs. Given that most emigrants come from the lower part of the distribution of earnings, raising non-taxable income thresholds and allowances for dependents, increasing the role of targeted rather than universal benefits and other ways of promoting progressivity seem to be the right direction in further development of the tax and benefit system. Given a high proportion of former registered unemployed among emigrants, investments in training programmes for the unemployed are welcome. Latvia should avoid policy changes - and discard existing policies - which increase motivation to emigrate among large groups of population, especially in such fields as education, employment, health care, taxation and benefits. State and local governments should actively foster diaspora engagement in economic and social development and expand Latvia's "virtual borders". At the EU level, Latvia (together with other new member states) should actively promote creation of a mechanism to compensate the countries of origin of migrants for the loss of human capital, labour force and reproductive potential. 


\section{Notes}

1. The fact that the net outflow of air and sea passengers in 2011 fell below the 2009 level (see Table 4.4) can be explained by reasons other than an actual decline in total emigration such as a reduction in the number of Air Baltic flights, or a shift in preferences towards land transport following the complete opening of the German labour market and a growing share of families among the emigrants.

2. Outflow to the Russian Federation remains stable, although at a level $30 \%$ higher than in 2008 .

3. For the period between 2012Q2 and 2013Q1, however, the issuance of new SSNs fell just $27 \%$. By this measure, migration to the United Kingdom from Estonia and Lithuania in 2012 was $30 \%$ lower than in 2011, while emigration from Poland declined by less than 5\% (Department for Work and Pensions, 2013).

4. Hazans (2003, Tables A4.1-A4.4) provides a detailed comparison of earnings.

5. EURES - The European Job Mobility Portal, available at http://ec.europa.eu/eures/

6 See Hazans and Philips (2010, Section 7) for a detailed discussion of the impact of emigration on Latvia's labour market and economy in 2004-07.

7. In Ireland and in the United Kingdom, the citizens of new member states need to register to obtain living and working permits, but if the documents are in order, permits are guaranteed without any specific prerequisites (Brucker et al., 2009, Table 2.1).

8. Brucker et al. (2009, Tables 6.7 and 6.8) showed that in 2004-07 returns to schooling for post-accession immigrants from new member states in the United Kingdom were quite low: just $2 \%$ per year of schooling. Moreover, $82 \%$ of tertiary-educated representatives of this group worked in medium- or low-skilled jobs.

9. Indirectly - via spouses holding Latvian citizenship, as well as via social networks new migration possibilities emerged also for non-citizens. Nevertheless, their position in terms of mobility options worsened compared to that of citizens.

10. Latvian Labour Force Survey data, 2009/Q4 and 2010/Q1 average.

11. See www.citizensinformation.ie/en/social_welfare/social_welfare payments/; www.hmrc.gov.uk/childbenefit/, accessed on 15August 2011 and refer to year 2011.

12. The actual level could be even higher given that information on labour market status is missing for $7-9 \%$ of emigrants in these two waves.

13. Guestworkers include also short-term and seasonal migrant workers. On the other hand, in the context mentioned here (due to LFS design) guestworkers are still considered as household members back home (those who moved as entire families are therefore not guestworkers).

14. These results are obtained by summing the effects from the rows "Female" and "Female with children". 
15. The concept of potential emigrants here is somewhat broader than the one used earlier in this section. Here, it refers to accepting a hypothetical offer rather than planning emigration.

16. The effect of emigration on total labour force participation is theoretically ambiguous. Changes in the age structure caused by emigration suggest a negative effect, while higher real wages and lower hiring standards tend to increase the participation rate, especially among disadvantaged groups (Hazans and Philips, 2010; Hazans, 2011a). In fact, the activity rate of the Latvian working-age population was much higher in 2011-12 than in the pre-accession period, but it could have been even higher in absence of emigration. 


\section{References}

Anosova, D., A. Zasova, K. Sonin and A.Vanags (2012), "Structural or Cyclical? Unemployment in Latvia since the 2008-09 Financial Crisis", available at SSRN, http://dx.doi.org/10.2139/ssrn.2255130.

Aujean, L. (2012), "Recent trends in Intra-EU Mobility: A Focus on CEE Member States", Presentation at Advisory Committee on Free movement of Workers, 30 October 2012.

Baltic Course (2013), "Hazans: Official Migration Data Not in Line with Actual Situation in Latvia", www.baltic-course.com/eng/analytics/?doc=78062.

Borjas, G.J. (1999), "Immigration and Welfare Magnets", Journal of Labour Economics, Vol. 17, No. 4, pp. 607-637.

Borjas, G.J. (1987), "Self-selection and the Earnings of Immigrants", American Economic Review, Vol. 77, No. 4, pp. 531-553.

Brucker, H., T. Baas, S. Bertoli, T. Boeri et al. (2009), "Labour Mobility within the EU in the Context of Enlargement and the Functioning of the Transitional Arrangements", European Integration Consortium (IAB, CMR, fRDB, GEP, WIFO, wiiw), Nuremberg.

Department for Works and Pensions (2013), "National Insurance Number Allocations to Adult Overseas Nationals Entering the United Kingdom - Registrations to March 2013", https://sv.stat-xplore.dwp.gov.uk/views/.

Düll, N. (2013), "Geographical Labour Mobility in the Context of the Crisis: Germany", European Employment Observatory.

European Commission (2012), Employment and Social Developments in Europe 2011.

European Commission (2011), Labour Market Developments in Europe, 2011, http://ec.europa.eu/economy finance/publications/publication summary-20110809 en.htm.

European Commission (2010), Employment in Europe 2010, Publications Office of the European Union, Luxembourg, http://ec.europa.eu/social/main.jsp?catId=738\&langId $=$ en\&pubId $=593$.

Fic, T., D. Holland, P. Paluchowski, A. Rincon-Aznar and L. Stokes (2011), "Labour Mobility within the EU - The Impact of Enlargement and Transitional Arrangements", NIESR Discussion Paper, No. 379 (Revised August 2011).

Gormsen, C. and M. Pytlikova (2012), "Diasporas and Foreign Direct Investments", Paper presented at EALE Annual Conference, Bonn, 20-23 September 2012, www.eale.nl/Conference2012/program/Parallel\%20session\%20B.htm. 
Hazans, M (2013a), "Structural or Cyclical? Unemployment in Latvia since 2008-09 Financial Crisis", Public presentation, March 1, 2013, www.sseriga.edu/en/news-andevents/upcoming-events/event-archive/2013/presentation.html.

Hazans, M. (2013b), "Developments in the Latvian Labor Market", Presentation at the conference "Beyond Recovery: Foundations for Inclusive Growth in Latvia", Riga, June 3-4, 2013, www.worldbank.org/content/dam/Worldbank/Feature\%20Story/ ECA/Poland $\% 20$ presentations $\% 20$ merged.pdf.

Hazans, M. (2012), "Selectivity of Migrants from Baltic Countries Before and After Enlargement and Responses to the Crisis", in B. Galgóczi, J. Leschke and A. Watt (eds), Intra-EU Migration in Troubled Times: Skills Mismatch, Return Migration and Policy Responses, Farnham, Ashgate, United Kingdom, pp. 169-207.

Hazans, M. (2011a), "Labour Market Integration of Ethnic Minorities in Latvia", in M. Kahanec and K.F. Zimmermann (eds), Ethnic Diversity in European Labour Markets: Challenges and Solutions, Cheltenham, United Kingdom, Northampton, Edward Elgar, United States, pp. 163-197.

Hazans, M. (2011b), "The Changing face of Latvian Emigration, 2000-2010", in B. Zepa and E. Kḷave (eds), Latvia. Human Development Report 2010/2011: National Identity, Mobility and Capability. Advanced Social and Political Research Institute of the University of Latvia, Riga, pp. 77-101.

Hazans, M. (2010), “Ethnic Minorities in Latvian Labour Market, 1997-2009: Outcomes, Integration Drivers and Barriers", in N. Mužnieks (ed.), How Integrated is Latvian Society? An Audit of Achievements, Failures and Challenges, University of Latvia Press, Riga, pp. 125-158.

Hazans, M. (2009), "Migration of the labour force of the Baltic countries", Public presentation, 21 April 2009, www.politika.lv/temas/fwd eiropa/17224/.

Hazans, M. (2008), “Post-enlargement Return Migrants' Earnings Premium: Evidence from Latvia", EALE 2008 Paper, No. 541, available at SSRN, http://ssrn.com/abstract $=1269728$.

Hazans, M. (2007), "Coping with Growth and Emigration: Latvian Labour Market Before and After EU Accession", available at SSRN, http://dx.doi.org/10.2139/ssrn.971198.

Hazans, M. (2003), "Potential Emigration of Latvian Labour Force after Joining the EU and its Impact on Latvian Labour Market", available at SSRN, http://dx.doi.org/10.2139/ssrn.739305.

Hazans, M. and K. Philips (2010), "The Post-Enlargement Migration Experience in the Baltic Labor Markets", in M. Kahanec and K.F. Zimmermann (eds), EU Labor Markets After Post-Enlargement Migration, Springer, Berlin-Heidelberg, pp. 255-304, also available as IZA Discussion Paper No. 5878, http://ftp.iza.org/dp5878.pdf.

Holland, D., T. Fic, A. Rincon-Aznar, L. Stokes and P. Paluchowski (2011), "Labour Mobility within the EU - The Impact of Enlargement and the Functioning of the Transitional Arrangements", Study commissioned by the Directorate-General for Employment, Social Affairs, and Equal Opportunities, NIESR, London, http://ec.europa.eu/social/BlobServlet?docId=7120\&langId=en, case studies available at http://ec.europa.eu/social/BlobServlet?docId=7191\&langId=en. 
Javorcik, B.S., Ç. Özden, M. Spatareanu and C. Neagu (2011), "Migrant Networks and Foreign Direct Investment", Journal of Development Economics, Vol.94, pp. 231-241.

Kaczmarczyk, P., M. Mioduszewska and A. Żylicz (2010), "Impact of the Post-accession Migration on the Polish Labour Market", in M. Kahanec and K.F. Zimmermann (eds), EU Labor Markets After Post-Enlargement Migration, Springer, Berlin-Heidelberg, pp. 219-253.

Krasnopjorovs, O. (2012a), "Vai emigrācijas vilnis izsīkst?" [Does the emigration slow down?], www.makroekonomika.lv/vai-emigracijas-vilnis-izsikst.

Krasnopjorovs, O. (2012b), "Factors of Economic Growth in Latvia", $\mathrm{PhD}$ thesis, University of Latvia, Riga.

Krasnopjorovs, O. (2011), "Cik cilvēku Latviju pameta, un cik vēl pametīs?” (How many people have left Latvia and how many will leave?), www.makroekonomika.lv/cikcilveku-latviju-pameta-un-cik-vel-pametis.

Krišjāne, Z., E. Apsīte-Beriņa, A. Lulle, M. Bērziņš and J. Auzāns (2012), "Mobilo draugu raksturojums" [Profile of mobile friends], Public presentation 6 November 2012, University of Latvia, Riga.

Krišjāne, Z., M. Brants, Z. Cunska, P. Eglīte, B. Ivbulis, A. Lulle, I. Markausa, N. Titova et al. (2007), Geographic Mobility of Labour Force, University of Latvia Press, Riga.

Kugler, M. and H. Rapoport (2005), "Skilled Emigration, Business Networks and Foreign Direct Investment”, CESifo Working Paper Series, No. 1455.

Lee, E.S. (1966), “A Theory of Migration”, Demography, Vol. 3, No. 1, pp. 47-57.

LETA (2013), "Publiskotie migrācijas dati neatspoguḷojot patieso situāciju" [Published migration data do not reflect real situation], www.tvnet.lv/zinas/viedokli/472148publiskotie_migracijas_dati_neatspogulojot_patieso_situaciju.

OECD (2012), Connecting with Emigrants. A Global Profile of Diasporas, OECD Publishing, Paris, http://dx.doi.org/10.1787/9789264177949-en.

Ribakova, Z. (2009), "EURES - An Instrument for Facilitating Free Movement of Labour with 15 years of Experience in European Employment Services", Presentation at the conference of the State Employment Agency.

Rose, R. (2000), "New Baltic Barometer IV: A Survey Study”, Centre for the Study of Public Policy, University of Strathclyde, Glasgow.

Rutkowski, J. (2007), "From the Shortage of Jobs to the Shortage of Skilled Workers: Labor Markets in the EU New Member States", IZA Discussion Paper, No. 3202, Bonn.

Sjaastad, L.A. (1962), “The Costs and Returns of Human Migration”, Journal of Political Economy, Vol. 70, No. 5, pp. 80-93.

SKDS - Marketing and Public Opinion Research Centre (2006), "A Study on Latvian Diasporas”, Part I, SKDS, Riga.

Statistics Latvia (2013a), "Long-term migration", http://data.csb.gov.lv/, Tables IBG01, IBG021, IBG022, IBG04, IBG041. 
Statistics Latvia (2013b), "Iedzīvotāju skaits un ilgtermiņa migrācija" [Population figure and longterm migration. Methodology note, in Latvian], www.csb.gov.lv/sites/ default/files/dati/demstat_metodologija_ver09.pdf.

Statistics Latvia (2013c), "Long-term international migration: Data Collection", www.csb.gov.lv/en/statistikas-temas/metodologija/long-term-migration-population37180.html\#Data_collection.

Statistics Latvia (2012a), “On Population Census 2011”, Press Release, 10 February, 2012, www.csb.gov.lv/en/statistikas-temas/population-census-2011-33604.html.

Statistics Latvia (2012b), "Largest Population Decrease in Latvia Recorded in 2009 and 2010", Press Release, July 31, 2012, www.csb.gov.lv/en/notikumi/largest-populationdecrease-latvia-recorded-2009-and-2010-35950.html.

Statistics Latvia (2012c), "Results of Population Census 2011”, www.csb.gov.lv/statistikas-temas/tautas-skaitisana-28290.html.

Zasova, A. (2012), "Econometric Assessment of Performance of Latvian Labour Market", PhD Thesis, University of Latvia, Riga.

Zepa, B. and E. Kḷave (eds) (2011), Latvia. Human Development Report 2010/2011: National Identity, Mobility and Capability, Advanced Social and Political Research Institute of the University of Latvia, Riga. 


\section{Annex 4.A1}

\section{Emigration accounting based on Latvian Population Census and Population Registry}

Preliminary results of the Latvian Population Census (Statistics Latvia, 2012a, 2012c) report net emigration of 189000 persons between the censuses of 2000 and 2011. While this estimate is very close to independent estimates (Hazans, 2011a, 2011b; Krasnopjorovs, 2011, 2012a), the underlying methodology suffers from a number of shortcomings. First, since a significant part of the information was collected online, the physical presence of the respondent in Latvia was not always verified. Second, the census questionnaire asked about living abroad after 1989 (rather than after 2000). By covering such a long period, respondents may have been reluctant to answer this question and thus emigration may have been underreported. Third, 188000 persons have been recognised as present in the country (and 160000 , absent) based solely on their appearance (or lack thereof) in the State Social Insurance Agency data, Health Payment Centre data, local government data or data of the Ministry of Education and Science during the 12 months before the census.

Finally, the estimate in question was obtained by summing three components: i) "official" emigration based on Population Registry data (treating the difference between identified change in population and natural increase as net migration rather than, as it was done before, accounting only for declared emigration); ii) emigration of family members, as reported by the census respondents; iii) persons recognised as emigrants based on lack of information. The exact year of departure for these people remains unknown. While the latter component accounts for the majority of emigrants, however, Statistics Latvia $(2012 b, 2012 c)$ applied the dynamics of registered and reported emigration (driven mainly by the former) on this unregistered/undeclared emigration, thus overestimating pre-enlargement emigration at the expense of post-enlargement emigration and emigration during the crisis (see Figure 4.3, as well as Figure 4.A1.1).

In Figure 4.A1.1, Panel B, we construct an alternative time series (for years 2000-10), based on the same data used by Statistics Latvia under a different assumption, namely that, between 2000 and 2010, the [gross] outflow of emigrants for whom the year of departure is unknown, followed the same pattern as our estimated [gross] outflows of Latvian nationals to EEA countries. The latter have been obtained by summing inflows to the United Kingdom and Ireland as measured by allocated social security numbers, and inflows to other EEA countries estimated by the statistical authorities of these countries; see Box 4.1 for details. The resulting dynamics of net emigration is similar to that derived from our estimates completely based on receiving countries' statistics but suggests somewhat smaller outflows in 2006-07 and larger ones in 2009 and 2011. 
Figure 4.A1.1. Population outflows from and inflows to Latvia based on Latvian data sources, 2000-11

Thousands

A. Official estimate
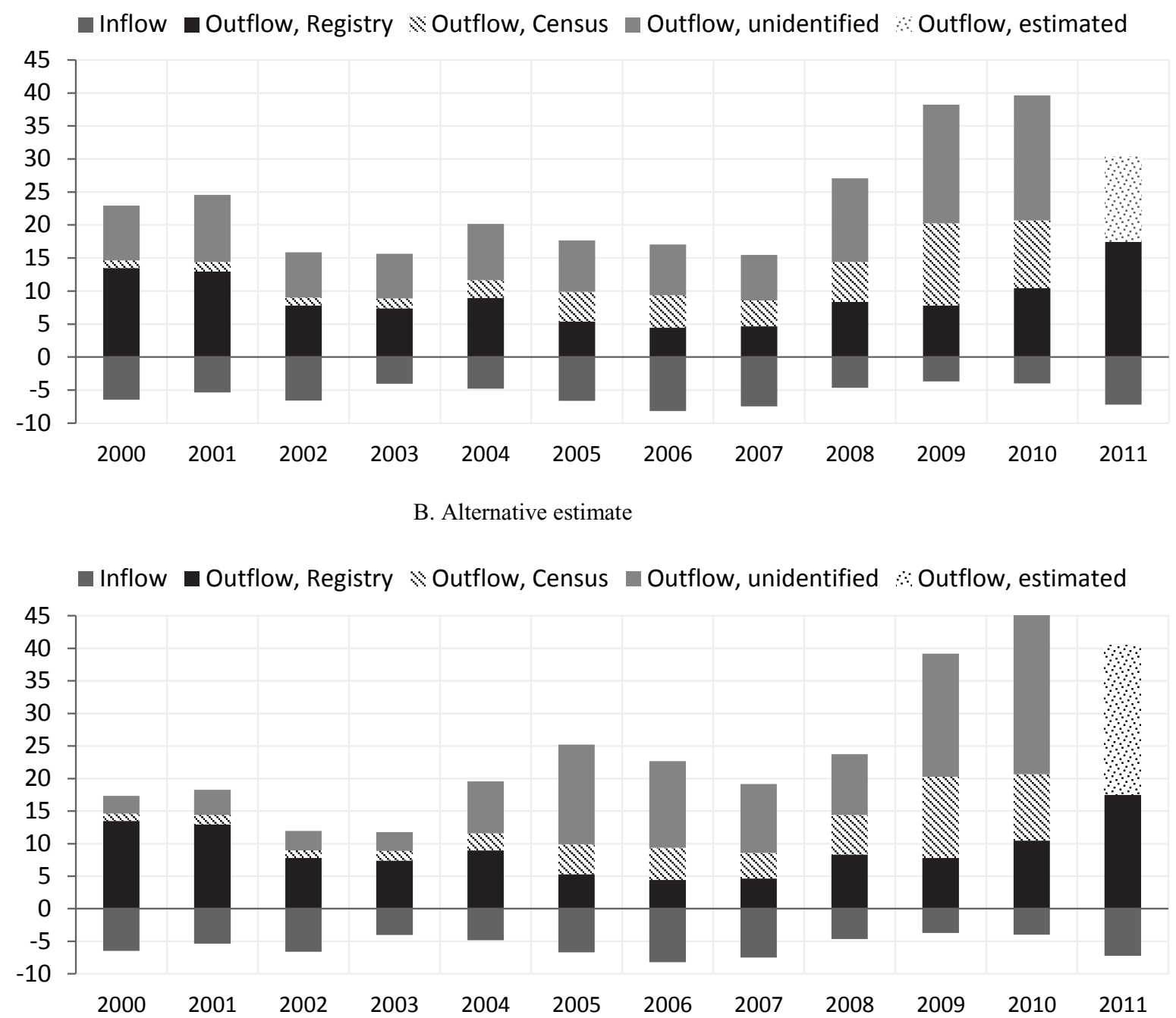

Note: "Outflow, Registry" and "Outflow, Census" refer to emigrants identified from Population Registry and Population Census 2011 records, respectively. "Outflow, unidentified" stands for the number of persons recognised as emigrants, but for whom the exact year of their departure is unknown. In the official estimate (Panel A), the latter component is assumed to have followed the weighted dynamics of "Outflow, Registry" and "Outflow, Census". In the alternative estimate (Panel B), we assumed unregistered emigrants to follow the same pattern as gross outflows to EEA countries, estimated on the basis of receiving country statistics (see Box 4.1 for details). "Outflow, estimated" is the difference between estimated gross outflow and registered emigration in 2011. Our estimate of gross outflow (in Panel B) is larger than the official one (in Panel A) mainly because we take into account United Kingdom data on the allocation of National Insurance numbers. Inflows for all years are as reported by Statistics Latvia.

Source: Author's calculations based on data from Statistics Latvia and receiving countries. 


\title{
Chapter 5
}

\section{Matching the skills of return migrants to labour market needs in Poland}

\author{
Paweł Kaczmarczyk
}

Centre of Migration Research, University of Warsaw

The chapter looks at the phenomenon of recent return migration to Poland with special emphasis on the labour market performance of returnees. The chapter examines the post-2004 migration in terms of its characteristics, including the extent to which it has been temporary migration, and assesses the share of the population with migration experience. Differences between migrants and those without migration experience are examined, and a distinction is made returning migrants who left before or after 2004. The impact of migration experience on labour market outcomes is examined, including in terms of unemployment and entrepreneurial activity, and some explanation for this impact is provided. The chapter concludes with a discussion of policies to support returning migrants and lessons from these programmes. 


\section{Introduction}

Poland is undoubtedly an emigration country, with a century-old tradition of international emigration. The country witnessed transcontinental migration to the United States, large flows of labour migration to Western European countries prior to World War I, significant outflows during the Solidarity era and numerous "incomplete migrants" in the 1990s. ${ }^{1}$ Even so, accession to the European Union marks a turning point in migration trends from Poland. The post-accession years saw a spectacular increase in the scale of Polish emigration which, in the regional context, can only be compared to that of Romanian citizens. The increase in the number of Polish migrants abroad (reaching roughly 7\% of the total population in 2007) was accompanied by growing public interest in migration as a socio-economic phenomenon. Massive emigration after EU enlargement sparked an intense debate about (expected) return migration and its impacts. The chapter will assess the scale and structure of recent return migration to Poland and the performance of returnees in the Polish labour market. Special emphasis will be placed on skill transfer and the match between migrants' skills and labour market needs, with an eye to policy implications. The chapter hypothesises that due to particular features of recent migration from Poland (temporary, labour migration, significant scale of underemployment abroad) well-tailored migration policies would be needed to efficiently improve labour market performance of returnees upon return.

This chapter examines the scale and structural features of return migration to Poland, especially short-term or circular migration practices. It then looks at the labour market re-integration of Polish returnees, and explores the issue of "social remittances". Finally, it summarises official programmes and initiatives which aim to create incentives for returnees and / or to improve their return to Poland.

\section{Return migration to Poland - scale and structural features}

How to assess the scale of return migration to Poland? Traditionally, temporary mobility constituted a significant portion of Polish migration, both before and during the post-enlargement period. How we define (and understand) the return movement thus becomes a critical question. Contrary to the classic case of settled migrants returning to their country of origin, for many Polish migrants "return" can often mean only a short break between periods spent abroad. We shall thus refer to both "typical" return migrants and persons with migratory experience (mostly temporary migrants currently residing in Poland but who may emigrate again in the future). The term liquid or fluid migration is increasingly used (Engbersen et al., 2012; Grabowska and Okólski, 2010) to refer to this phenomenon involving Polish as well as other Central and Eastern European (CEE) migrants. It points to very flexible migration plans or strategies which, to some extent, are the consequence of the free movement regime introduced in 2004. In statistical terms, recent migrants are extremely difficult to follow. Administrative data sources capture only a portion of the phenomenon, while stock data are usually more reliable. At any rate, most estimates point to the massive scale of the phenomenon.

According to stock estimates, the number of Polish nationals staying temporarily abroad peaked in 2007, reaching 227 million persons (Fihel, 2011; Kaczmarczyk, 2011) - see also Figure 5.1 and Table 5.1. 
Figure 5.1. Stock of Polish migrants staying temporarily abroad, 2002-11

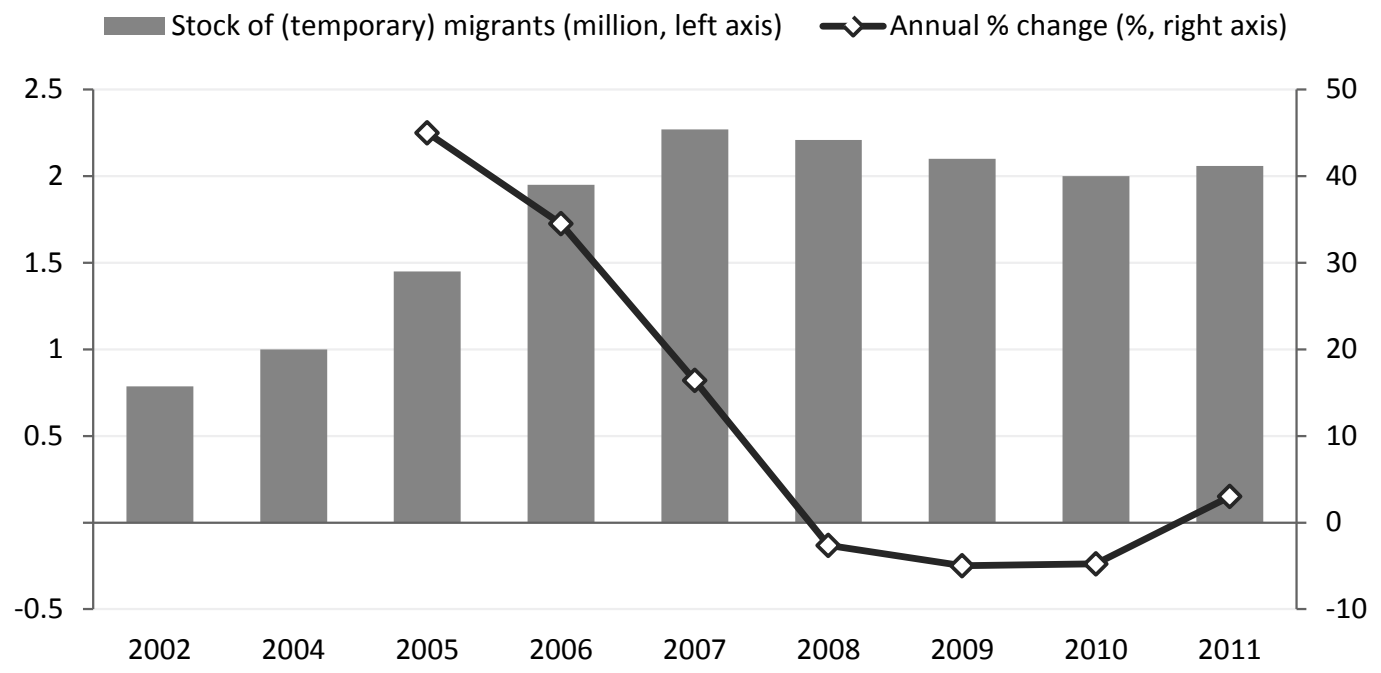

Note: "Temporarily abroad" is defined as "permanent residents who have stayed in a foreign country for longer than three months".

Source: Author's calculations based on data from the Central Statistical Office (CSO).

Table 5.1. Stock of Polish migrants residing temporarily abroad, 2002-11

Main destination countries, thousands

\begin{tabular}{|c|c|c|c|c|c|c|c|c|c|}
\hline Destination & $\begin{array}{c}\text { Population census } \\
\text { (May 2002) }\end{array}$ & 2004 & 2005 & 2006 & 2007 & 2008 & 2009 & 2010 & 2011 \\
\hline Total & 786 & 1000 & 1450 & 1950 & 2270 & 2210 & 2100 & 2000 & 2060 \\
\hline of which : Europe & 461 & 770 & 1200 & 1610 & 1925 & 1887 & 1765 & 1685 & 1754 \\
\hline \multicolumn{10}{|l|}{ of which: } \\
\hline Austria & 11 & 15 & 25 & 34 & 39 & 40 & 36 & 29 & 25 \\
\hline Belgium & 14 & 13 & 21 & 28 & 31 & 33 & 34 & 45 & 47 \\
\hline Czech Republic & . & . & . & . & 8 & 10 & 9 & 7 & 7 \\
\hline Denmark & . & . & & . & 17 & 19 & 20 & 19 & 21 \\
\hline Finland & 0.3 & 0.4 & 0.7 & 3 & 4 & 4 & 3 & 3 & 2 \\
\hline France & 21 & 30 & 44 & 49 & 55 & 56 & 60 & 60 & 62 \\
\hline Germany & 294 & 385 & 430 & 450 & 490 & 490 & 465 & 440 & 470 \\
\hline Greece & 10 & 13 & 17 & 20 & 20 & 20 & 16 & 16 & 15 \\
\hline Ireland & 2 & 15 & 76 & 120 & 200 & 180 & 140 & 133 & 120 \\
\hline Italy & 39 & 59 & 70 & 85 & 87 & 88 & 88 & 92 & 94 \\
\hline Netherlands & 10 & 23 & 43 & 55 & 98 & 108 & 98 & 92 & 95 \\
\hline Norway & & & & & 36 & 38 & 45 & 50 & 56 \\
\hline Portugal & 0.3 & 0.5 & 0.6 & 1 & 1 & 1 & 1 & 1 & 1 \\
\hline Spain & 14 & 26 & 37 & 44 & 80 & 83 & 84 & 48 & 40 \\
\hline Sweden & 6 & 11 & 17 & 25 & 27 & 29 & 31 & 33 & 36 \\
\hline United Kingdom & 24 & 150 & 340 & 580 & 690 & 650 & 595 & 580 & 625 \\
\hline
\end{tabular}

Source: CSO - Central Statistical Office (2012), "Informacja o rozmiarach i kierunkach emigracji z Polski w latach 2004-2011 notatka informacyjna" [Information on the scale and destinations of Polish emigrants, 2004-2011. Press Release], CSO, Warsaw. 
In 2009, this number was as high as 2.1 million, i.e. it decreased slightly and remained more or less stable in the following years. The difference between these two stocks (around 150000 ), is obviously lower than the actual number of returnees (see below) but may point to the significance of the phenomenon. As shown in Table 5.1 below, the decline in the stock of Polish migrants abroad, is mostly due to a decrease in a few countries: those that experienced the highest inflows in the post-2004 period (the United Kingdom, Ireland, and the Netherlands) on the one hand; and those that were hard hit by the economic crisis on the other (most notably Spain and Ireland, with a spectacular increase in the stock of migrants between 2002 and 2007 followed by a significant drop).

Polish Labour Force Survey (LFS) data may represent a better source of information on return migration. Moreover, having introduced, in the second quarter of 2008, a special module dedicated to migrants, the Polish LFS reported 580000 return migrants (or persons with migratory experience, as the figure includes both long-term and short-term migrants) between 2004 and the second quarter of 2008 (213 000 in 2007 alone). If we consider a longer time span, the figures are much higher. According to the 2008 LFS, around $4.2 \%$ of Poles (i.e. 1.28 million) had a migration experience (had been abroad for at least three months), most of whom (1.05 million $-2.7 \%$ of the total population) returned after 1989 (CSO, 2008). In 2008, the total number of Polish emigrants and return migrants was 3.5 million, i.e. $9 \%$ of the total population of Poland (Anacka and Fihel, 2012b).

The highest number of return migrants was provided by the Public Opinion Research Centre survey, and equalled 2.9 million persons (over $9 \%$ of the adult population). These were people who had worked abroad sometime between 1997 and 2008, and were residing in Poland at the time of the survey (i.e. 2008) (Fiałkowska and Szczepański, 2012). The most valid data on return migration to Poland is expected with the publication of the final results of the 2011 national census (first quarter of 2013).To sum up, massive migration in the post-accession period led to a significant reverse flow of return migrants. This is clearly consistent with the observation expressed many years ago by Ernst Ravenstein, to the effect that return migration often accompanies migratory movements.

\section{Structural features of return migration to Poland}

Generally, the profile of return migrants reflects the structure of migration from Poland. As estimated by Fiałkowska and Szczepański (2012) on the basis of LFS data, return migrants who came back to Poland after 2000 are younger and better educated than the population without migration experience. The largest differences were found with respect to the attainment of tertiary and primary education $(24.4 \%$ for returnees vs. $14.9 \%$ for non-migrants; and $8.7 \%$ for returnees vs. $27.2 \%$ for non-migrants, respectively). With respect to other socio-demographic characteristics, return migrants also tend to be male and single (Fiałkowska and Szczepański, 2012).

According to the 2008 LFS, only $35 \%$ of return migrants stayed abroad for a period longer than one year, which again reflects the structure of recent outflows characterised by a significant share of temporary migrants. Most of those coming back to Poland returned from Germany (more than 30\%), the United States and the United Kingdom (about 11\% from each country) (CSO, 2008). The share of returnees from EU countries, including the United Kingdom, was as high as 60\%-70\% (depending on the period) and significantly increased in recent years. Anacka and Fihel (2012a) offer a different perspective. They performed a detailed analysis of migrant selectivity, comparing emigrants and returnees. This kind of analysis is extremely useful, as it may point to possible causal factors related to return migration. Table 5.2 presents the most important findings of this analysis. 
Table 5.2. Selected characteristics of emigrants and return migrants

\begin{tabular}{|c|c|c|c|c|}
\hline & Characteristic & Emigrants (\%) & Return migrants (\%) & Selectivity index ${ }^{1}$ \\
\hline \multirow{2}{*}{ Sex } & Male & 61.1 & 64 & 0.05 \\
\hline & Female & 38.9 & 36 & -0.07 \\
\hline \multirow{5}{*}{ Level of education } & University degree & 14.1 & 10.2 & -0.28 \\
\hline & Secondary & 14.1 & 12.9 & -0.09 \\
\hline & Secondary vocational & 30 & 29.7 & -0.01 \\
\hline & Vocational & 33.4 & 38.6 & 0.16 \\
\hline & Primary & 8.4 & 8.5 & 0.01 \\
\hline \multirow{2}{*}{ Type of settlement } & Urban & 57.1 & 43.2 & -0.24 \\
\hline & Rural & 42.9 & 56.8 & 0.33 \\
\hline \multirow{14}{*}{ Country of destination } & EU-15 & 80.8 & 82.6 & 0.02 \\
\hline & Austria & 2 & 1.4 & -0.3 \\
\hline & Belgium & 2.4 & 2 & -0.18 \\
\hline & France & 3.4 & 3.8 & 0.12 \\
\hline & Germany & 23.3 & 30.9 & 0.33 \\
\hline & Greece & 1.3 & 1.3 & -0.01 \\
\hline & Ireland & 6.6 & 3.7 & -0.43 \\
\hline & Italy & 8.9 & 9.8 & 0.1 \\
\hline & Netherlands & 4.8 & 5.5 & 0.13 \\
\hline & Spain & 2.9 & 3.1 & 0.1 \\
\hline & Sweden & 1.4 & 1.7 & 0.2 \\
\hline & United Kingdom & 22.8 & 18 & -0.21 \\
\hline & Norway & 1.8 & 2 & 0.09 \\
\hline & United States & 11.8 & 8 & -0.33 \\
\hline
\end{tabular}

1. The selectivity index compares the proportion of return migrants falling in each category with the respective proportion among migrants abroad (who did not return to Poland).

Source: Anacka, M. and A. Fihel (2012), "Return Migration to Poland in the Post-Accession Period", in J. Leschke, B. Galgoczi and A. Watt (eds), Migration and Labour Markets in Troubled Times, Ashgate, Aldershot.

No significant differences between migrants and return migrants were found with respect to age or sex. In contrast, marked differences were noted with respect to education - the difference between migrants and return migrants was greatest with regard to vocational education (in favour of returnees). Interestingly, among returnees there was a clear overrepresentation of those originating from villages and small towns, which is not necessarily in line with commonly expressed expectations concerning potential return migrants who were supposed to target rather large cities with efficient labour markets (Kaczmarczyk and Okólski, 2008). On the other hand, selectivity indexes for destination countries (countries of residence before return) reveal the highest propensity to return among migrants to countries such as Italy, France or Germany, suggesting that recently observed return migration is mostly a product of pre-2004 migratory waves and does not involve the most recent outflows.

With regard to the geography of the phenomenon (which seems crucial to migration policy and initiatives targeting returnees) clear patterns of selectivity have been observed. Figure 5.2 presents selectivity index values by geographical region (vovoidship). Three groups of regions have been identified: "pulling regions" (with SI $>0.1$ ), "pushing out regions" (SI<-0.1) and "unspecified regions" $(-0.1<\mathrm{SI}<0.1)$ (Anacka and Fihel, 2012a). 
Figure 5.2. Return migrant selectivity index by geographical region, Poland

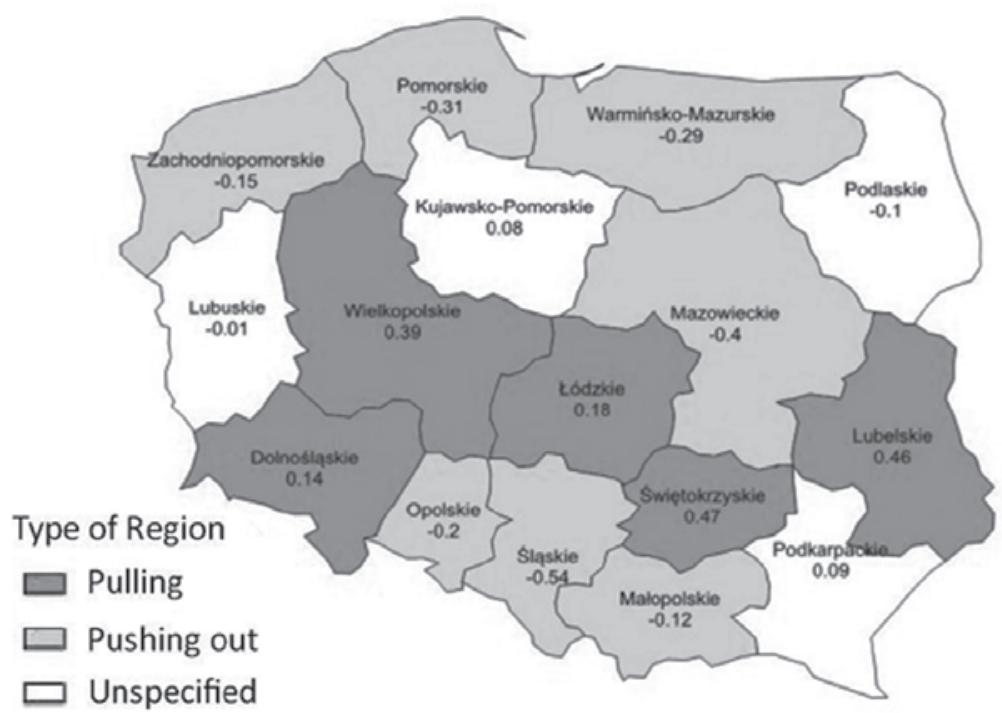

Source: Author's calculations based on Anacka, M. and A. Fihel (2012), "Return Migration to Poland in the Post-Accession Period", in J. Leschke, B. Galgoczi and A. Watt (eds), Migration and Labour Markets in Troubled Times, Ashgate, Aldershot.

As shown in the above figure, Polish regions differ greatly with respect to selectivity of return migration. On the one hand, there are regions where the share of returnees is higher than that of emigrants such as Lubelskie, Podlaskie, Świętokrzyskie and Wielkopolskie. On the other hand, in such regions as Śląskie, Mazowieckie and Pomorskie, the percentage of returnees is lower than that of emigrants (Anacka and Fihel, 2012a). This pattern contradicts expectation. In fact, the share of return migrants is lower in regions with relatively well developed labour markets and large cities (Warsaw, Katowice, Gdańsk). The fact that the regions attracting returnees are those with relatively long traditions of emigration and not necessarily those with strong pull factors, offers additional support to the hypothesis that what we are witnessing is the return of people who left Poland prior to EU enlargement

\section{The labour market performance of return migrants}

The re-integration of return migrants into the labour market is a crucial issue in the debate about the impact of return migration. The labour market performance of return migrants shapes the very assessment of migration and plays a significant role in the migration-development nexus (de Haas, 2010). Secondly, successful re-integration into the labour market is the main target of most migration policies targeting returnees. The most reliable information on the labour market performance of Polish return migrants can be drawn from the LFS module described above. Generally speaking, according to the 2008 LFS migrant module, the labour market position of Polish returnees was not significantly different from that of non-migrants. Around $69 \%$ of return migrants were employed as compared to $63 \%$ of non-migrants. At the same time, however, the unemployment rate of returnees was higher by about 2 percentage points (CSO, 2008; Fiałkowska and Szczepański, 2012). 
An in-depth, rigorous analysis based on the same data was performed by Anacka and Fihel $(2012 \mathrm{~b}){ }^{2}{ }^{2}$ The general picture that emerged is consistent with the results cited above. Return migrants were more exposed than non-migrants to the risk of unemployment. At the same time, their participation rates were higher than those of nonmigrants. In order to control for additional variables which could be responsible for a particular labour market position, a set of multinomial logit models was estimated (in which a distinction between short-term and long-term migration was considered). Results can be summarised as follows (Anacka and Fihel, 2012b):

- The risk of unemployment was much higher for short-term migrants (2.5 times higher) than for non-migrants.

- A similar pattern was observed among long-term migrants: for those aged 18-35 years, the risk of unemployment was 3-5 times higher than for nonmigrants.

- The highest risk of unemployment was observed among those with secondary education (particularly the long-term migrants among them).

- Generally, migration experience was associated with higher participation rates in the labour market.

- This was not true, however, for young persons with a background of short-term migration for whom the risk of labour market inactivity was around twice as high as in reference categories.

- Experience of migration thus seems to affect labour market performance in a negative way, particularly in the case of young people and those who spent a short period of time abroad (3-12 months). This effect is partially attributable to the profile of Polish post-accession migrants, many of whom left Poland after completing their education without ever entering the Polish labour market. In such cases - especially if combined with depreciation of skills abroad - reintegration in Poland upon return can be extremely difficult. A commonly discussed issue in the context of return migration is the question of skill transfer. Three factors are liable to compromise the ability of Polish return migrants to transfer to their country of origin, skills acquired in their country of destination:

- The majority of Polish migrants abroad are employed in jobs that are not in line with their education (so that skill transfer between Poland and destination countries also rarely occurs). According to CSO data, this was true of approximately $66 \%$ of Polish return migrants (CSO, 2008).

- Most Poles working abroad are considerably overqualified. For example, while close to $30 \%$ of Polish migrants in the United Kingdom have tertiary education, the vast majority of them (around 80\%-90\% ) are employed in jobs that require far lower qualifications (mostly in secondary sectors of the dual labour market offering manual jobs) (Kaczmarczyk, 2011).

- Mostly due to the above reasons, for Polish migrants abroad, the rate of return to human capital investment is low (or even extremely low) (Kaczmarczyk and Tyrowicz, 2012). This may explain not only specific strategies applied by migrants but also their decisions regarding return or further migration to a different country. 
Skill transfer is thus unlikely in Poland. The following points are worth considering however:

- There is evidence to suggest, that return migrants are more likely than non-migrants to hold stable employment contracts (SSC, 2010; SSC, 2011a; SSC, 2011b).

- Labour market reintegration in Poland tends to be easier for well-educated migrants; the position of persons with primary and secondary education is generally much more difficult (for these groups, self-employment serves as an escape from unemployment) (SSC, 2010; SSC, 2011a; SSC, 2011b).

- Return migrants tend to be self-employed. Regional studies indicate that the share of the self-employed (5\%-12\%, depending on the region) is significantly higher among return migrants than among non-migrants (SSC, 2010; SSC, 2011a; SSC, 2011b). While there is no clear evidence that self-employment is a dominant reintegration strategy (Fiałkowska and Szczepański, 2012) however, it seems particularly frequent among migrants who completed tertiary education in Poland but were employed in the secondary sectors abroad and faced problems with finding a job upon return.

On the basis of available data, it would be difficult to conclude that a migration/mobility experience is an advantage on the Polish labour market. Brain waste/deskilling abroad appear to be major problems. In addition, expectations regarding employment upon return were often frustrated, particularly in the time of economic downturn, becoming a major issue for return migrants.

\section{Social remittances}

Migration may affect sending countries not only through economic mechanisms such as labour markets or remittances. In many cases - particularly when migrants retain close links with sending communities or return to their places of origin - the socio-cultural impacts of migration, or "social remittances", should also be considered. According to de Haas (2009), migration involves not only flows of people but also flows of ideas, norms etc. Migration may thus alter socio-economic structures in sending communities (social, class and ethnic hierarchies), traditional care arrangements, family structure, gender relations or particular modes of behaviour (culture of migration, entrepreneurship).

In light of the relatively large scale of return migration to Poland, such cultural changes may be expected, but have not been studied extensively so far. As shown by Gmaj and Małek (2010), many returnees surveyed stated that they have learned a new organisational culture which may be useful in old or new working environments. According to Social Diagnosis ${ }^{3}$ data, persons with migration experience assess their chances on the Polish labour market in a more positive way than non-migrants, are more self-confident, open minded and ready to accept different lifestyles, but are relatively critical towards religious or political authority.

A closer look at the data reveals however, that return migrants share roughly the same characteristics as non-migrants, often contrary to expectations. For example, the average number of close friends amounted to 7.1 in case of returnees and 6.9 in case of non-migrants; return migrants and non-migrants similarly assessed the impact of foreigners on Poland ("Foreigners do have too much impact on life in Poland" - the average score, on a scale of 1 to 7 , was as high as 4.6 for return migrants and 4.4 for non-migrants); or level of self-responsibility ("Everyone is responsible for his own life" -2.34 and 2.37 , respectively). Tables 5.3-5.5 present other examples (to avoid problems with self-selection and provide a robustness check, columns 4 and 5 include information on persons aged 18-35 years only). ${ }^{4}$ 
Table 5.3. Assessment of one's own life

Percentages

\begin{tabular}{l|cc|cc}
\hline \multirow{2}{*}{ How do you feel? } & \multicolumn{2}{|c|}{ Total population } & \multicolumn{2}{c}{$\mathbf{1 8 - 3 5}$ year-olds } \\
\cline { 2 - 5 } & Non-migrants & Returnees & Non-migrants & Return migrants \\
\hline Very happy & 9.6 & 15.9 & 15.6 & 18.9 \\
Fairly happy & 70.7 & 63 & 71.8 & 60.1 \\
Not so happy & 18.1 & 19.8 & 12 & 19.1 \\
Unhappy & 1.6 & 1.4 & 0.7 & 1 \\
\hline Number of observations & 25604 & 816 & 8719 & 494 \\
\hline
\end{tabular}

Source: Author's calculations based on data from Social Diagnosis.

As shown above, generally return migrants assess their own life more positively: the share of those declaring themselves "very happy" was $9.6 \%$ among non-migrants and about $16 \%$ among returnees. Nevertheless, when we limit our analysis to persons aged $18-35$, those differences are much smaller (15.6 and 18.9 respectively).

Table 5.4. Assessment of socio-economic reforms started in 1989

Percentages

\begin{tabular}{l|cc|cc}
\hline \multirow{2}{*}{ How do you assess the socio- } & \multicolumn{2}{|c|}{ Total population } & \multicolumn{2}{c}{$\mathbf{1 8 - 3 5}$ year-olds } \\
\cline { 2 - 5 } economic transition in Poland? & Non-migrants & Return migrants & Non-migrants & Return migrants \\
\hline Successful & 13.8 & 14.8 & 14.5 & 12.6 \\
Not successful & 36.6 & 33.7 & 19.8 & 26.1 \\
Difficult to say & 49.6 & 51.5 & 65.7 & 61.3 \\
\hline Number of observations & 25604 & 816 & 8719 & 494 \\
\hline
\end{tabular}

Source: Author's calculations based on data from Social Diagnosis.

As can be seen in Table 5.4, young return migrants seem to be far more critical with regard to the socio-economic transition than young non-migrants. Last but not least, Table 5.5 summarises the assessment of main factors responsible for a person's life. Interestingly, returnees tend to believe in the power of authorities (policy makers, government representatives) more than non-migrants and also in their own power to change reality. Nevertheless, comparison of persons aged 18-35 reveals an (unexpected?) similarity between the responses obtained from the two groups.

Table 5.5. Main factors responsible for one's own life

Percentages of positive answers

\begin{tabular}{l|cc|cc}
\hline \multirow{2}{*}{ My life depends on: } & \multicolumn{2}{|c|}{ Total population } & \multicolumn{2}{c}{ 18-35 year-olds } \\
\cline { 2 - 5 } & Non-migrants & Return migrants & Non-migrants & Return migrants \\
\hline Government/policy makers & 7.9 & 9.8 & 6.3 & 8.7 \\
Other people & 26.2 & 24.2 & 32.6 & 25.9 \\
Fate / God & 41.8 & 36.6 & 33.4 & 42.8 \\
My own & 71.4 & 73.8 & 79.9 & 73.1 \\
\hline Number of observations & 25604 & 816 & 8719 & 494 \\
\hline
\end{tabular}

Source: Author's calculations based on data from Social Diagnosis. 
The analysis of Social Diagnosis data suggests that social remittances appear to be a limited phenomenon, which is, at any rate, difficult to ascertain. Conceivably, in the case of Poland, the recent nature of the social processes in question means that potential effects may become visible only in the longer term.

\section{Policies and programmes targeting return migrants}

Poland had policies targeting return migrants as early as the $1920 \mathrm{~s}$. Nevertheless, the issue entered into the public debate only in the late 1990s, and it was not before 2006 - following the massive scale of post-enlargement wave of emigration and the emergence of shortages in the Polish labour market - that discussion regarding return migration and the reintegration of returnees into the Polish labour market gained momentum. Several of the more important initiatives taken as a result to encourage the return of emigrants and Polish citizens staying temporarily abroad are discussed below. Table 5.6 summarises some of them.

Table 5.6. Programmes/initiatives targeting potential Polish return migrants

\begin{tabular}{|c|c|c|c|c|}
\hline $\begin{array}{c}\text { Name of the } \\
\text { programme/ } \\
\text { initiative }\end{array}$ & Institutions responsible & Main target groups & Time frame & $\begin{array}{l}\text { Level of } \\
\text { implementation }\end{array}$ \\
\hline $\begin{array}{l}\text { "Masz PLan na } \\
\text { powrót?" [Have you } \\
\text { got a PLan to return?] }\end{array}$ & \begin{tabular}{|l|} 
Chancellory of the Prime \\
Minister, Ministry of Labour \\
and Social Policy, Centre \\
of Human Resources \\
Development \\
\end{tabular} & $\begin{array}{l}\text { All migrants staying } \\
\text { abroad, persons } \\
\text { considering return to } \\
\text { Poland and return } \\
\text { migrants }\end{array}$ & $\begin{array}{l}\text { Since September } 2008 \\
\text { (still active) }\end{array}$ & National \\
\hline $\begin{array}{l}\text { Wracajdopolski.pl } \\
\text { [ReturntoPoland.pl] }\end{array}$ & \begin{tabular}{|l|}
$\begin{array}{l}\text { Hays Polska, Polish-British } \\
\text { Chamber of Commerce }\end{array}$ \\
\end{tabular} & $\begin{array}{l}\text { Polish migrants abroad, } \\
\text { particularly highly skilled } \\
\text { migrants }\end{array}$ & October 2007-11 & National \\
\hline $\begin{array}{l}\text { "Zostań w Polsce - } \\
\text { swoim szefem" } \\
\text { [Become your own } \\
\text { boss - stay in Poland] }\end{array}$ & \begin{tabular}{|l|} 
Urząd Marszałkowski, \\
Wyższa Szkoła Finansów i \\
Prawa
\end{tabular} & \begin{tabular}{|l|} 
Returnees in region of \\
Mazovia (especially \\
migrants aged 45 and \\
over, women, and people \\
who were forced to return \\
due to loss of job abroad)
\end{tabular} & $\begin{array}{l}\text { Since September } 2010 \\
\text { (still active) }\end{array}$ & Regional \\
\hline $\begin{array}{l}12 \text { miast - wracać, ale } \\
\text { dokąd? [The } 12 \text { cities } \\
\text { - to go back, but } \\
\text { where to?] }\end{array}$ & $\begin{array}{l}\text { Poland Street Association } \\
\text { (Polish NGO based in } \\
\text { London), municipalities of } \\
12 \text { biggest Polish cities: } \\
\text { Białystok, Bydgoszcz, } \\
\text { Gdańsk, Katowice, } \\
\text { Kraków, Lublin, Łódź, } \\
\text { Poznań, Rzeszów, } \\
\text { Szczecin, Warszawa i } \\
\text { Wrocław }\end{array}$ & $\begin{array}{l}\text { Polish migrants in the } \\
\text { United Kingdom }\end{array}$ & $\begin{array}{l}\text { January-August } 2009 \\
\text { (stopped due to financial } \\
\text { problems and economic } \\
\text { downturn) }\end{array}$ & Regional \\
\hline Powroty [Returns] & Fundacja Barka & \begin{tabular}{|l|}
$\begin{array}{l}\text { Polish migrants in } \\
\text { London (particularly if } \\
\text { homeless) }\end{array}$ \\
\end{tabular} & $\begin{array}{l}\text { Since January } 2007 \text { (still } \\
\text { active) }\end{array}$ & Regional \\
\hline $\begin{array}{l}\text { Opolskie - tutaj } \\
\text { zostaję ['Opolskie - } \\
\text { here I stay'] } \\
\end{array}$ & $\begin{array}{l}\text { Self-Government of Opole } \\
\text { region, Regional Labour } \\
\text { Office in Opole }\end{array}$ & $\begin{array}{l}\text { Persons staying abroad, } \\
\text { graduates, people looking } \\
\text { for a job in the region }\end{array}$ & 2009 & Regional \\
\hline $\begin{array}{l}\text { Wrócić i co dalej? [To } \\
\text { return and what next?] }\end{array}$ & \begin{tabular}{|l|} 
Fundacja Fundusz Lokalny \\
Ziemi Biłgorajskiej, \\
Powiatowy Urząd \\
Pracy, Biłgorajska Agencja \\
Rozwoju Regionalnego
\end{tabular} & $\begin{array}{l}\text { Young (below 35) Polish } \\
\text { migrants and their } \\
\text { families }\end{array}$ & January 2007-June 2009 & Local \\
\hline
\end{tabular}

Source: Fiałkowska, K. and M. Szczepański (2012), “Labour Mobility Within the EU - Impacts of Return Migration. Poland Case Study”, Eurofound - PPMI, unpublished manuscript. 


\section{National initiatives}

In 2006, the Ministry of Foreign Affairs announced the programme "Closer to work, closer to Poland" (Blizej pracy, blizej Polski) which was followed by a programme targeting the Polish diaspora. The first mention of a government "return programme" was in October 2007, when the Minister of Labour and Social Policy announced its outlines, but Polish parliamentary elections and a subsequent change of government prevented any action (Szczepański, 2010). In April 2008, the Interdepartmental Working Group on Return Migration formulated a programme targeting return migrants. Importantly, this programme was based on two main premises: first, that returns are an inevitable consequence of mass emigration, and second, that the responsibility of the government should not be to influence individual migrants' decisions to return, but to enable a "smooth" return to Poland and reintegration into its labour market. The programme consisted of six packages but only five have been implemented so far $^{5}$ (Fiałkowska and Szczepański, 2012; see also Table 5.6):

- $\quad$ Package 1 - services for returning migrants: a dedicated website, a "Return migrant handbook Social Diagnosis - a large-scale, countrywide survey devoted to the analysis of social norms and various forms of participation. Returner" (see also point 5), online employment office services, support for migrants with respect to vocational training, advice on investment and business opportunities in Poland.

- Package 2 - removal of barriers for persons planning to return to Poland: introduction of the Tax Abolition Act in order to avoid double taxation (2008), introduction of tax credits and investment allowances, grants for individual technology transfer, facilitated recognition of degrees and qualifications acquired abroad, easier acquisition or restoration of Polish citizenship.

- Package 3 - help for individual return migrants and their families, abroad as well as in Poland, particularly in the field of education (e.g. help for school children).

- Package 4 - interventions in the public administration, including the training of civil servants expected to come into contact with return migrants.

- Package 5 - information and promotion. In late 2008, a governmental campaign named "Have you got a PLan to return?" (where "PL" is the international abbreviation for Poland) was launched, to provide Poles who are considering or have already decided to return to Poland with all the necessary information for a smooth return to Poland and successful reintegration. Activities included the publication of a manual for return migrants ("A Returner") and the launching of the programme's official website (www.powroty.gov.pl). ${ }^{6}$

Due to the very structure of the initiative and its aims, it is extremely difficult to evaluate. Nevertheless, the programme as well its underlying approach influenced the debate on return migration in Poland affecting other initiatives dedicated to return migrants.

\section{Regional and local initiatives}

Several noteworthy regional and local initiatives have been introduced by local governments, NGOs or private companies (Fiałkowska and Szczepański, 2012; see also Table 5.6): 
- Return, a programme run by the Barka Foundation (Polish NGO based in London), was among the first initiatives targeting Polish migrants abroad. The programme, launched in 2007, targeted Polish emigrants in extreme difficulty (mostly homeless people and addicts). The idea was to provide transportation to Poland and participation in reintegration programmes. According to data provided by the Barka Foundation, so far, about 900 migrants have returned from the United Kingdom to Poland for social rehabilitation, detoxification, and employment programmes. No data is available on their further reintegration.

- $\quad$ To return and what next? (Wrócić i co dalej) was a programme active between 2007 and 2009, launched by the Local Labour Office and Agency of Regional Development in Biłgoraj. The programme's objective was to create local infrastructure by providing training and assistance for young people intending to start their own business locally. Several local NGOs were actively engaged.

- Opolskie voivodship - here I stay (Opolskie - tutaj zostaje) is a programme initiated in 2008 by the self-government of the Opolskie voivodship and the Regional Labour Office in Opole. The main goals were to increase work and educational opportunities in the region and encourage the return of people working abroad. Target groups were graduates, unemployed persons and persons residing and working abroad (mostly in the United Kingdom, Germany and the Netherlands).

- ReturntoPoland.pl (Wracajdopolski.pl) was launched in the third quarter of 2007 by the Polish branch of HAYES (an international human resources company) in co-operation with the Polish-British Chamber of Commerce and the Polish Ministry of Labour and Social Policy (the programme is not active at the moment). The programme's main objective was to address the shortages of skilled workers on the Polish labour market. Its main target group was therefore Poles working abroad in the IT, banking and finance sectors. HAYES played a major role in this programme, being responsible for information and training activities abroad as well as upon return.

- $\quad$ The 12 cities. To go back, but where to? (12 miast. Wracać, ale dokad?), introduced in 2009 by Poland Street (a London-based Polish diaspora organisation), was one of the most ambitious initiatives to encourage return, drawing much media attention. Twelve Polish cities were to be promoted in London through monthly presentations covering different aspects relevant to return migration, such as potential for individual development, educational and labour market opportunities and business opportunities. Meetings were open to the public and aroused much interest in the United Kingdom. Unfortunately, the programme was abandoned shortly after its inception due to the deteriorating economic situation in Poland.

- $\quad$ Become your own boss - stay in Poland (Zostań w Polsce - swoim szefem) was a programme launched in 2010 by the Warsaw Municipality in co-operation with the Higher School of Finance and Management in Warsaw. The aim was to encourage return migrants and Polish emigrants abroad to establish innovative enterprises, in the Mazowieckie region. Activities included training and the preparation of individual business plans, grants and donations covering six months of operating costs.

The above initiatives suffer from a number of shortcomings. First, only few of them (including the governmental programme Have you got a PLan to return? launched in 2008) could be described as evidence-based programmes, having clear assumptions, aims 
and objectives. This was partially due to a limited knowledge of Polish migration in general and of returnees in particular. Second, in most cases the evaluation criteria of the initiatives in question remain unknown or have been formulated in a very general way, making assessment difficult. In addition, as in the case of "The 12 cities" programme, initial plans were often disrupted by the economic downturn. Changes in economic conditions affecting both by migrants and institutions/organisations may be a partially responsible for the fact that most of the programmes are no longer active. Third, the need under Polish law, to avoid discrimination against Polish non-migrants is probably the reason why most programmes concentrate on providing information to returnees and Polish migrants abroad, or on training, with a special focus on self-employment. Lastly, and perhaps most importantly, it may be argued that, as with integration programmes targeting immigrants, reintegration programmes for returnees should above all be grounded in an efficient labour market support system. Unfortunately, however, in Poland - as in many other sending countries - the general labour market support system is highly inefficient.

\section{Conclusion}

In the second half of the 2000 s, return migration emerged as an important topic in Polish public debate. This was due to a few reasons. First, the scale of emigration in the post-accession period was so massive that large-scale return migration was (and is still) expected. Second, the economic crisis had a profound effect on the situation of migrants in many countries, and was expected to boost return migration. Third, anecdotal evidence pointed to relative difficulties in the reintegration of return migrants in the Polish labour market.

The question of return migration and its effects is closely linked to the "crowding-out hypothesis" proposed by Kaczmarczyk and Okólski (2008). Accession to the European Union and post-accession mass migration facilitated - for the very first time in contemporary history - the outflow of the "economically redundant" population from economically backward regions. Available evidence suggests that one of the most important post-accession migrant groups comprised young and relatively well-educated persons departing from regions with weak labour markets and a significant share (or remnants) of semi-subsistence economy. Following this line of reasoning, one may argue that even if post-accession flows have only had a moderate impact on Poland in the short run (including unemployment, economic activity or wages), this "crowding out effect" can significantly improve development potential in the longer term. Recent migration can bring about significant changes in labour market structure and its institutional setup. Essentially, while affecting the oversupply of labour it makes all reforms of the labour market easier (or even feasible). Return migration can be helpful, but may also hamper the mechanism described above. Available evidence suggests that a migration experience may influence labour market performance in a negative way, especially for young persons and short-term migrants. This effect is partially attributable to the very profile of Polish post-accession migrants (e.g. a large share of persons who leave Poland shortly after finishing their education without ever having entered the Polish labour market), and to their position in the labour markets of destination countries. Thus, for many returnees reintegration in Poland upon return can be extremely difficult. Personalised programmes (focusing on individual needs and advantages) may help pave the way of potential return migrants to successful return and reintegration. 


\section{Notes}

1. Okólski (2001) defines "incomplete migration" as quasi-migratory in character, with often irregular stay or work, and although they draw economic benefits from migration and spend time abroad, they maintain close ties with home.

2. Note, however, that the study did not address endogeneity nor selection mechanisms among return migrants (self-selection) and thus should be treated with caution.

3. Social Diagnosis - a large-scale, countrywide survey devoted to the analysis of social norms and various forms of participation.

4. Given that migrants are usually younger than the sending population, this is the most critical variable responsible for potential differences between the populations under analysis.

5. A package targeting specific groups, such as medical professionals, students or second- generation migrants is still in preparation. To some extent, this is due to controversies regarding possible discrimination against non-migrants.

6. In July 2011, the "Powroty" website was incorporated into the official website of the Polish Public Employment Services (ZielonaLinia.gov.pl). 


\section{References}

Anacka, M. and A. Fihel (2012a), "Return Migration to Poland in the Post-Accession Period", in J. Leschke, B. Galgoczi and A. Watt (eds), EU Labour Migration and Labour Markets in Troubled Times, Ashgate, Aldershot.

Anacka, M. and A. Fihel (2012b), "Wpływ doświadczenia migracyjnego na aktywność zawodową migrantów powrotnych" [Impact of migration experience, labour force of return migrants], unpublished manuscript.

CSO - Central Statistical Office (2012), "Informacja o rozmiarach i kierunkach emigracji z Polski w latach 2004-2011 - notatka informacyjna" [Information on the scale and destinations of Polish emigrants, 2004-2011. Press Release], CSO, Warsaw.

CSO (2008), "Informacja o badaniach zasobów imigracyjnych w Polsce w 2008 r. notatka Informacyjna" [Information on research on immigration resources in Poland in 2008. Press Release], CSO, Warsaw.

Engbersen, G., A. Leerkes, I. Grabowska-Lusinska, E. Snel and J. Burgers (2012), "Fourfold Labour Migration. On the Differential Attachments of Migrants from Central and Eastern Europe", Journal of Ethnic and Migration Studies (forthcoming).

Fiałkowska, K. and M. Szczepański (2012), "Labour Mobility Within the EU - Impacts of Return Migration. Poland Case Study", Eurofound - PPMI, unpublished manuscript.

Fihel, A. (ed.) (2011), "Recent Trends in International Migration in Poland: The 2011 SOPEMI report", CMR Working Paper, Vol. 52, No. 110, CMR, Warsaw.

Gmaj, K. and A. Małek (2010), "Powroty Polaków po 2004 roku: wyniki badania jakościowego" [Returns of Poles after 2004: results of qualitative research], w: Poakcesyjne migracje powrotne Polaków: geneza, przyczyny i konsekwencje [Post-Accession Return Migrations of Poles: Background, Reasons and Consequences], Biuletyn Naukowy Rzecznika Praw Obywatelskich, No. 69, Październik, Warsaw.

Grabowska, I. and M. Okólski (2010), Emigracja ostatnia? [The end of emigration?], Scholar, Warsaw.

de Haas, H. (2010), "Migration and Development: A Theoretical Perspective", International Migration Review. Vol. 44, No. 1, pp. 1-38.

Kaczmarczyk, P. (ed.) (2011), "Recent Trends in International Migration in Poland: The 2010 SOPEMI report”, CMR Working Paper, Vol. 51, No. 109, CMR, Warsaw.

Kaczmarczyk, P. and M. Okólski (2008), "Demographic and Labour-Market Impacts of Migration on Poland", Oxford Review of Economic Policy, Vol. 24, No. 3, pp. 600-625. 
Kaczmarczyk, P. and J. Tyrowicz (2012), "Be or Not To Be (Mobile)? Dilemmas of the Highly Educated Polish Migrants", unpublished manuscript.

Okólski, M. (2001). "Incomplete Migration. A New Form of Mobility in Central and Eastern Europe. The Case of Polish and Ukrainian migrants", in C. Wallace and D. Stola (eds.), Patterns of Migration in Central Europe, Houndmills/Basingstoke/Hampshire: Palgrave Macmillan, pp. 105-128.

SSC - Strategic Consulting Centre (2011a), "Powroty z migracji zagranicznych do Małopolski. Skala zjawiska, charakterystyka oraz potencjał powracających" [Return form emigration to Małopolska. Scale of the Phenomenon, characteristic, and Potential of returnees], Strategic Consulting Centre, Cracow.

SSC (2011b), "Wyjazdy i powroty z emigracji mieszkańców Województwa Śląskiego" [Departures and returns from emigration of inhabitants of Śląskie Voivodship], Strategic Consulting Centre, Cracow.

SSC (2010), "Migracja powrotna w Województwie Dolnośląskim. Skala zjawiska, potencjał oraz pogłębiona charakterystyka powracających" [Return migration in the Dolny Śląsk Voivodship. Scale of the phenomenon, potential and characteristic of returnees], Strategic Consulting Centre, Cracow.

Szczepański, M. (2010), “Analiza polityki państwa wobec migracji powrotnych. Przypadek Polski" [Analysis of state's policy towards returning migrants. The case of Poland], in M. Lesińska (ed.), Polityka państwa wobec migracji powrotnych własnych obywateli. Teoria i praktyka [State's Policy towards return migration of its national. Theory and practice], CMR Working Papers, Vol. 44, No. 102, CMR, Warsaw. 


\title{
Chapter 6
}

\section{Mobilising migrants skills and resources in Romania}

\author{
Cristina Mereuta \\ Employment Expert, Romania
}

This chapter focuses on Romanian labour migration, its effects on origin and destination labour markets, and its impact on social and economic development, as well as on pressing demographic issues, such as population ageing. The chapter then examines the effect of departure of Romanian workers on unemployment and its relation to economic restructuring. The educational characteristics of Romanian migrants are examined in terms of destinations, occupations and employment sector. The main policy initiatives to address emigration and support return are described, in terms of features and the actors implementing them. The chapter concludes by looking at potential future evolution of emigration and its impact on Romania. 


\section{Introduction}

Romania has had a tortuous experience of international migration. With a very low mobility in 1950-90 due to restrictions imposed by the totalitarian regime, emigration (mostly permanent) suddenly increased in 1990-91. The main reasons for emigration were ethnicity (significant flows to Germany, Hungary and Israel), business (small scale border trade), studies, and career (especially in mathematics, IT and other technical fields).

In 1990, 96929 Romanian citizens settled permanently abroad, followed by over 44000 persons in 1991 and over 25000 in 1995 (Figure 6.1). Due to EU restrictions and strict immigration rules in Canada and the United States, Romanian emigration slowed down in the late 1990s.

The new millennium brought important changes in migration patterns in terms of the scale of permanent migration, professional fields and destination countries. Italy and Spain gained popularity among Romanians seeking work, and the number of Romanians settling permanently abroad has steadily decreased.

According to the National Institute of Statistics, between 2005 and 2010, the number of emigrants (Romanian citizens who settled permanently abroad), varied, peaking in 2006 (14 197 persons) and reaching a minimum in 2010 (7 906 persons; a 50\% decrease).

Figure 6.1. Romanian citizens settling permanently abroad, by nationality, 1990-2010

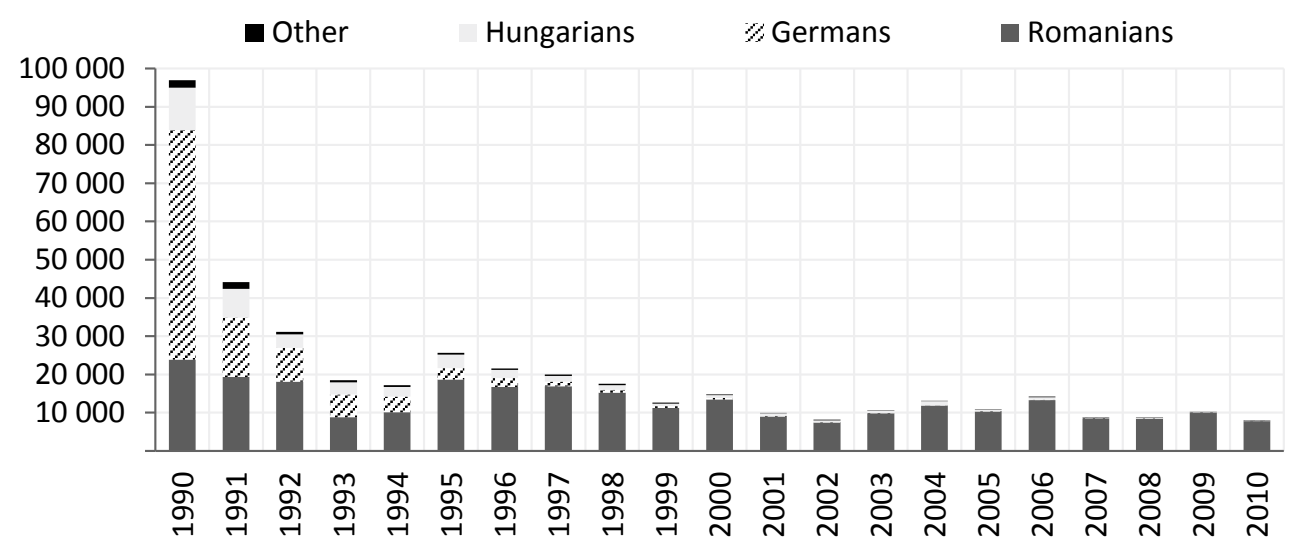

Source: National Institute of Statistics, Statistical Yearbook, various years.

During the period in question, the majority of emigrants were women (on average, women accounted for $63.5 \%$ of the total number of emigrants). In addition, an increase in the share of young emigrants (under 18 and aged 26-40) was registered.

The clear shift from ethnically motivated migration to migration motivated by work and life choices is reflected in the preponderance of ethnic minorities among emigrants in the early 1990s (Figure 6.1) on the one hand, and the clear predominance of Romanians in the period 2000-10 (reaching 99\% in 2010) on the other. Although national statistical data do not reflect the full extent of the phenomenon, it is nevertheless clear that, as soon as EU regulations allowed easier movement for Romanian citizens (e.g. lifting of visa requirements for short-term travel in Schengen countries), a growing trend of labour 
emigration began. The main triggers were (and partly still are) significant wage differentials between EU15 countries and Romania (Romanian minimum wage represents $15-20 \%$ of the minimum wage in certain destination countries) and a drastic reduction in job opportunities due to economic restructuring and the transition to a modernised economy. To a lesser extent, family circumstances, studies, a wish to change lifestyle or to acquire life and work experience were behind the decision to migrate.

Results of a survey by Sandu (2010) show that the opportunity to improve one's living conditions in Romania is an important reason for working abroad (specifically, $56 \%$ of those with a background of labour migration state that their plan for the next two-three years is to improve conditions of their current dwelling; $27 \%$ plan to open a business). Due to serious recessions in Europe in the 2008-12 period, emigration rates slowed down, although labour migration will continue to be considered a better prospect than work Romania in terms of employment and earnings, especially for the younger generation.

The 2011 population census ${ }^{1}$ provides a snapshot of certain aspects of population mobility, and a better assessment of the actual extent of Romanian emigration (and of its effects on small and medium-sized communities).

The final results of the Romanian 2011 census show a sharp population decline (by $7.2 \%$ compared to 2002). Mainly external emigration contributed to this outcome. According to the census, the usual resident population of Romania was 20121641 persons, of whom 385729 were temporarily absent (abroad for a period under 12 months). The number of persons abroad for a longer period (over 12 months) was 727 540. The Romanian National Institute of Statistics considers this figure an undercount, since for many long-term emigrants no family member or respondent was in Romania at the time of the census to report the information.

In spite of limitations, the census results for this population category show some significant elements: there is a balance in the gender ratio of emigrants; there are more urban residents (54\%); and emigrants are predominantly working-age (46\% in the 20-34 age cohort and 25\% in the 35-44 age cohort). Given the labour-oriented nature of Romanian emigration, the population decline will undoubtedly prove to have affected not only the country's demography but also its society and its labour market. This is already evident in several North-East counties in Romania which are important providers of external mobility. These counties are among the top five counties with the largest shares of persons abroad for a longer period, and also show a lower share of population aged 25-64 compared to the national average.

Table 6.1 shows the top ten destination countries for both the persons temporarily absent (under 12 months) and for those abroad for longer period (over 12 months). Not surprisingly, the main destination countries are the same for both categories.

Additional data from the respective population censuses and population statistics of the main destination countries contribute to the full grasp of the phenomenon. For example, Spain ${ }^{2}$ registered a strong increase in Romanian nationals compared to 2001 with a relative growth of $1287 \%$ (798 104 persons in 2011 compared with 57533 in 2001). In Italy, ${ }^{3}$ there were ten times more Romanians in 2011 (968 576) than in 2003 (95 039). Romanians are the largest group in the foreign population in both countries. 
Table 6.1. Persons left abroad (under and over 12 months), by country of destination

\begin{tabular}{lccc}
\hline & $\begin{array}{c}\text { Persons temporarily absent } \\
\text { (abroad for a period under 12 months) }\end{array}$ & $\begin{array}{c}\text { Persons abroad for a longer period } \\
\text { (over 12 months) }\end{array}$ & $\begin{array}{c}\text { Share of temporarily absent persons } \\
\text { among total reported abroad (\%) }\end{array}$ \\
\hline Italy & 169766 & 341296 & 33.2 \\
Spain & 71102 & 171163 & 29.3 \\
Germany & 29084 & 33089 & 46.8 \\
France & 21712 & 23205 & 48.3 \\
United Kingdom & 19064 & 40378 & 32.1 \\
Hungary & 14104 & 10291 & 57.8 \\
Greece & 9508 & 15851 & 37.5 \\
Belgium & 8257 & 11611 & 41.6 \\
Austria & 7737 & 9075 & 7651 \\
Portugal & 5271 & 727540 & 40.8 \\
\hline Total & 385729 & & 34.6 \\
\hline
\end{tabular}

Source: National Institute of Statistics, Population and Housing Censuses 2011.

It is worth noting that since 1992 Romania has registered a constant population decline from 22.81 million in 1992 to 21.68 million in 2002 and 19.04 million in 2012.

\section{Romania's experience in regulating labour migration}

Since 1990, Romania - having embarked on the road to EU membership - has modernised its labour market, especially with regard to labour mobility. In addition, negotiations were held with several states concerning the regulation of labour and social security arrangements. Traditionally, short-term labour migration was regulated through administrative arrangements for seasonal work, the oldest and most widely used instruments being those concluded with Germany (several agreements were signed in 1990-99). A milestone in Romanian labour migration was the bilateral labour agreement signed with Spain in 2002. Although the agreement was general in scope, it resulted mostly in labour migration destined for the agricultural and construction sectors - those in which demand was highest in 2002-08. This arrangement shaped future Romanian labour migration to Spain, which is still mainly characterised by low and medium-skilled migrants. Another major destination country for Romanian outflows is Italy. Interestingly, access to the Italian labour market was not regulated by labour agreements. Rather, cultural and linguistic affinity allowed an almost natural movement of Romanian workers towards sectors such as construction, domestic care services and agriculture in Italy.

Labour force survey data indicate that Romanian migrant workers moved mainly to Italy and Spain (about $40 \%$ to each country) and, to a lesser extent, to the United Kingdom, Germany and France (approximately $12 \%$ in total).

In the last decade, Romania became the European country with the largest outflow of migrants, with more than 2 million Romanians registered as residents in other EU countries, and over 70\% concentrated in Spain and Italy (Eurostat, 2011).

Among immigrants residing in EU countries, Romanians - whose numbers increased seven-fold between 2001 and 2010 - currently represent the largest group of EU citizens (6.6\% of all foreigners; second only to Turkish citizens, who represent $7.2 \%$ of foreigners). 
Romanian labour migration, initially a seasonal, circular movement of persons for work and study purposes (temporary work in Spain, Germany, Austria), later changed into a real option for long-term/indefinite stay, mainly in countries such Spain and Italy.

EU destinations appear to be linked to the migrant's level of skill and education. Highly skilled Romanian emigrants tend to head North (Germany, France, United Kingdom) to work in information and communication technologies, business and social service sectors, while those with vocational or less than secondary education tend to head South (Spain, Italy, Greece) to work in construction, domestic care services, housekeeping, hospitality, agriculture and manufacturing.

\section{The effects of emigration on the Romanian labour market}

During the 1990s and early 2000s, the outflow of Romanian workers represented an opportunity to reduce unemployment and alleviate the repercussions of economic restructuring.

In spite of this initial beneficial effect on the national labour market (which is still characterised by a low level of job availability), the sheer volume of labour emigration gave rise to several negative effects: labour shortages, skill gaps, distorted wage demand; depopulated areas, deepening of regional discrepancies; social problems with dependents (especially children) left behind; inflationary pressure (due to remittances).

Since 2006-07, the business sector has registered labour shortages, especially in construction, with a direct effect on wage demands. During 2007-08, Romanian employers made efforts to attract Romanians working abroad or to reduce the "appetite" of their staff for emigration.

A study carried out in 2007 by the National Research Institute for Labour and Social Protection (Ciuca et al., 2007) showed that most Romanians are ready for international mobility with a view to attain better employment. The types of jobs that are sought differ, however, between residents of urban and rural areas: urban residents tend to look for better jobs, especially better paid, while rural residents tend to look for any type of job.

The same study revealed that emigrants left the Romanian labour market from marginal jobs/situations (daily worker, unemployed or self-employed). Another interesting finding, which partly explains the high propensity for work emigration at the expense of internal mobility, is the frequent lack of information on job opportunities at the local, regional and national level.

According to medium- and long-term labour market forecasts conducted by the Romanian Ministry of Labour, Social Protection and Family, in co-operation with the National Research Institute for Labour and Social Protection, the highest risk of shortage is predicted to accumulate for International Standard Classification of Occupation (ISCO) groups 3 ("Technicians and associate professionals"), 7 ("Craft and related trades workers") and 8 ("Plant and machine operators and assemblers"). The Romanian National Agency for Employment (Public Employment Service) reported that vacancies have been repeatedly communicated by employers in clothing manufacturing, car manufacturing and building construction, with difficulties in finding suitable candidates (due to skill or location mismatch) and in placing jobseekers (due to low earnings, especially in clothing manufacturing).

Although last decade's migration patterns were marked by the emigration of lowskilled workers, emigration of highly skilled individuals also developed at a rapid pace, 
mainly based on student exchange programmes and rapid recruitment after graduation. Immigrant selection policies implemented by Germany, the United Kingdom and France attracted specialised workers to these countries, especially in the field of information and communication technologies. In recent years, the migration of health care workers has gained momentum, due also to significant wage reductions and poorer working conditions in the Romanian public sectors, coupled with an increasing demand in Western Europe for medium and highly skilled workers in the health sector (physicians, specialised nurses).

Finally, the phenomenon of children and teenagers left behind by migrant parents to be cared for by relatives or institutions ("home alone") represents a grave social problem, resulting in abuse, violation of children's rights, delinquency, poor educational performance etc.

\section{The effects of migration on domestic development}

Immigration as a mechanism for the replacement of workers and their skills is limited in Romania, especially due to low earnings. During 1991-2010, the yearly inflow of persons (by change of domicile) has been 1602 persons in 1991, 11907 in 1998, 8606 in 2009 and 7055 in 2010 (National Institute of Statistics, 2011), and - with the exception of 2001, 2007 and 2009 - net migration has been negative (Figure 6.2).

Figure 6.2. Net international migration, 1991-2010

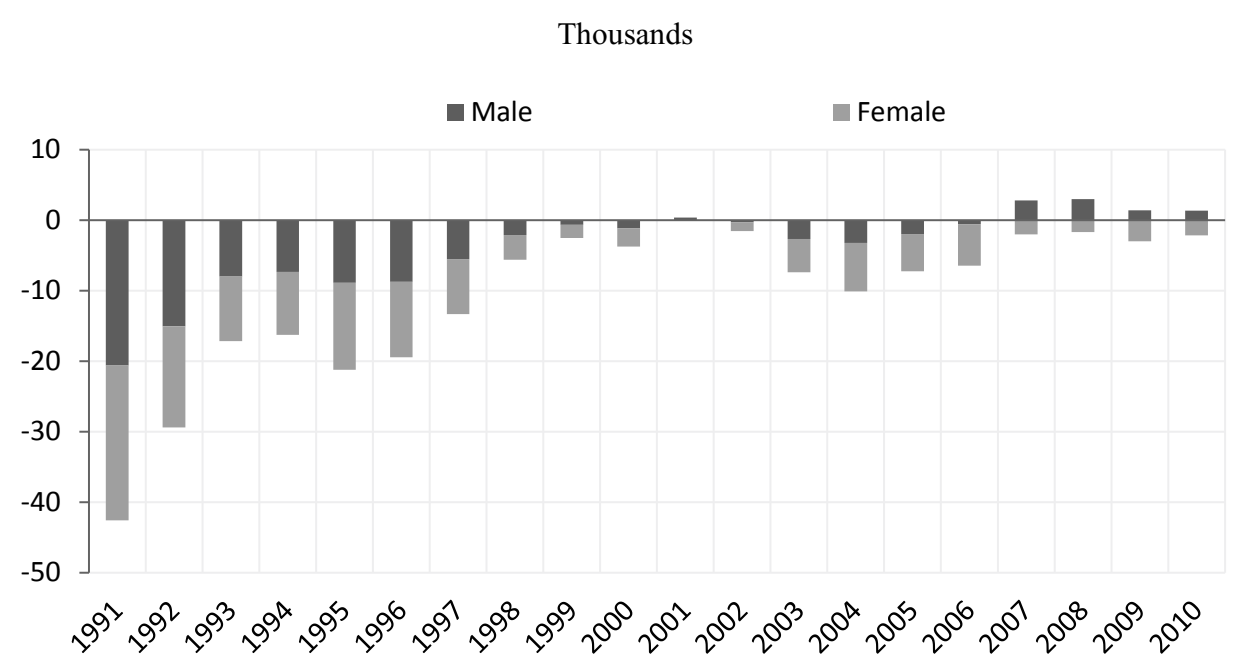

Source: National Institute of Statistics, Statistical Yearbook, various years.

The geographical distribution of immigrants is skewed. The capital region, BucharestIlfov, attracts over $40 \%$ of immigrants, followed by the North-East (13\%). Immigrants come mainly from the Republic of Moldova (over 33\%), Italy (14\%), the United States (6.2\%), France (5.7\%), China (5.3\%) and Turkey (4.5\%) (2009 data).

Young adults aged 26-40 make up about $50 \%$ of both emigration and immigration flows. The majority of immigrants are male $(60 \%)$ while the majority of emigrants are females $(63 \%)$. People with higher education represent $27 \%$ of both emigration and immigration flows. 
Another important feature of Romanian labour migration is the valuable impact on the economic and social status of the families left behind. Remittances directly fuelled business investments and consumption in Romania in the past decade. Foreign remittances peaked in 2008. Since then, however, due to the economic crisis, a declining trend has been observed.

The high level of remittances may point to the temporary character of Romanian emigration. According to World Bank data, in 2009 the value of remittances sent by Romanians working abroad amounted to about 3\% of Romanian GDP and was one of the highest among EU8+ two countries. The sheer volume of remittances, however, led to lower levels of economic activity in the remaining population. Money sent back by Romanian migrant workers represented, in a way, a second form of "welfare" deeply affecting recipients' willingness to work.

The last decade of migration in Romania triggered major social change. Traditionally immobile populations (mostly rural) suddenly benefited from the opportunities offered by labour migration with direct positive effects on the living standards of those back home (spouses, children, parents) as well as on individual adaptability.

Given the fact that Romanian migration is mainly based on family and community migration networks, an efficient match between skills and labour demand would be difficult to achieve through systems based on institutional actors.

\section{Skills aspects of return migration}

Studies show that, upon return, Romanian migrants use their newly acquired skills, technological and business knowledge to increase their productivity at the workplace, start businesses and enhance their mobility on the labour market (Sandu, 2006a).

Free, or almost free movement of workers contributed greatly to Romania's development. It increased labour force mobility, the transfer of skill, technology and work organisation models, and enhanced worker adaptability. Many self-employed individuals or small companies in the field of construction are based on work experience, skill and capital gained abroad.

According to Eurofound research which focused on Hungary, Latvia, Poland and Romania (Barcevičius et al., 2012), the foreign work experience of return migrants proves more valuable to highly skilled workers than for low-skilled workers.

\section{Measures to encourage return}

Migration channels affect policy approaches for stimulating return. The main migration channels from Romania are:

- Migration through family and community networks - most commonly used, especially in the context of restrictions imposed by destination countries in which informal (family and community) networks of support and facilitation are active. There are empirical examples of Romanian villages where a small group of successful emigrants formed the basis for mass labour migration.

- Legal migration facilitated by private agencies - a channel managed, since the beginning of the 1990s, by private agencies specialising mainly in the construction sector, and in emigration to Germany and Israel. 
- $\quad$ Legal migration mediated by state agencies - a channel strictly linked to bilateral labour agreements signed by Romania, and which allowed regulated, circular migration of Romanian workers in different economic sectors/occupations in the 1990 s and early 2000 s.

- $\quad$ Direct (non-mediated) migration - most used by qualified workers entering in direct contact with future employers abroad.

Considering these main migration channels, Romania's approach in responding to massive emigration and encouraging return focused on three elements: i) information; ii) entrepreneurship and large-scale investment; and iii) diversified public intervention. Only preliminary steps towards the implementation of policies focused on stimulating return have been taken (2007-08), however, as the impact of the domestic economic crisis diverted attention away from this issue. ${ }^{4}$

\section{Information}

Romanian migrant workers often lack important information and updates regarding opportunities to start a business or find satisfactory employment (mainly in terms of wages) in Romania in general, and in their regions of origin in particular.

Several information campaigns and labour exchanges have been organised in Italy and Spain by the Romanian Ministry of Labour, Family and Social Protection, in order to provide information as well as a concrete first step towards a decision to return - a job in Romania. A total of four events (information and job fair) were organised in 2008, in the four locations with the highest concentrations of Romanian workers: Castellon de la Plana (12-13 April) and Alcala de Henares (28 June) in Spain; Rome (24 February) and Turin (21 June) in Italy.

The following themes were covered: EU social security co-ordination - pensions, health, unemployment and family benefits; rights and obligations of working exercising mobility within the European Union; illegal/undeclared work risks; starting a business in Romania (including funding opportunities). Romanian companies (especially in construction, car industry, and manufacturing) presented vacancies during special job fairs organised in Spain and Italy for Romanian migrant workers (see Box 6.1).

\section{Box 6.1. Job fairs abroad}

A job fair was organised in Rome on 23 February 2008 by the Romanian Ministry of Labour, Family and Social Protection, the Romanian Embassy in Rome, and the National Agency of Employment. This was the first job fair organised by Romanian authorities abroad. The aims were to facilitate the encounters between Romanian employers and possible Romanian returnees, to support the employers in identifying the needed workers, to publicise the current vacancies from Romania, and to increase the chances of those who work irregularly in Italy to find a proper job in Romania. Approximately 1000 individuals attended the job fair, and around 7500 job offers were presented.

On 12-13 April 2008, an information/job fair was organised in Castellon de la Plana (Spain). Around 1300 participants attended, and 8000 jobs offers were presented. In addition to information on work and social security, relevant for migrant workers, special attention was paid to entrepreneurship in Romania (specific regulations; sources of funding). 
Although the main impediment to matching remained (the wage differential), information served as a good basis for a reassessment of options on the part of Romanian citizens who had left the country many years before. In 2008, the Romanian Government adopted an "Action Plan for promoting the return of Romanian migrant workers", 5 with the following objectives:

- $\quad$ to establish, maintain, and update databases periodically

- to conduct an information campaign on job opportunities in Romania, and actively recruit Romanian migrants for work in the Romanian labour market

- $\quad$ to stimulate return and professional reintegration of Romanian migrant workers by promoting a system for circular migration.

The Department for Romanians Abroad (see below) financed projects aimed at maintaining relations with Romanian communities abroad, including, for example, scholarships for graduate and post-graduate studies, research, and short-term training programmes to ethnic Romanians who established their permanent residence outside of Romania.

Interesting in this respect are also initiatives taken by associations ${ }^{6}$ of current and former students/graduates of foreign universities and/or international/European training programmes, who promote the transfer of knowledge and skill back to Romania (these initiatives are private, but provide valuable information, such as members' assessments of the current situation in Romania, career promotion opportunities, etc.).

In the various destination countries, numerous associations/organisations of Romanians have been established, and their activities focus on supporting diaspora members and strengthening ties with the country of origin. Members of Romanian migrant communities have facilitated the conclusion of co-operation agreements (e.g., town twinning) between local administrative bodies (municipalities, regional governments) in destination countries (especially Italy, Spain and Germany) and Romania. These instruments have fostered cultural, economic and social exchange and development.

\section{Entrepreneurship and large scale investments}

Entrepreneurship is quite limited in Romania relative to other countries. One study (Sandu, 2006b) found that only about $10 \%$ of the population are entrepreneurs or have a member of the family who is an entrepreneur. Among persons with experience "abroad" (travel or work), the share of entrepreneurs is higher (16\% and $23 \%$, respectively). Thus, foreign work experience is positively associated with entrepreneurial initiative. Capital, experience and contacts accumulated abroad explain these differences. The same study gives examples of businesses started upon return to Romania by applying business models learnt abroad. This is one area where return-support initiatives have been piloted (see Box 6.2).

Many studies and data show, that Romanians working abroad tend to spend their earnings on individual consumption and the improvement of their living conditions (mainly construction, extension or modernisation of their dwellings; purchase of cars and home appliances), and to a lesser extent on setting up a new business or buying land. 


\section{Box 6.2. Support for returning entrepreneurs}

Unicredit Group (Unicredit Tiriac Bank in Romania) managed, under the supervision of the Italian Ministry of Foreign Affairs, a special fund to support migrants who want to return and start a business in Romania. The project provided special banking tools to support investments in the country of origin, using the money earned in the destination country. The programme focused mainly on youth and female entrepreneurship. The total credit allocated was EUR 1.6 million (a EUR 20000 loan on average) and supported businesses in the health and care sector (35\%), business services sector (25\%), craftsmanship (25\%) wellness/rural tourism - individual or family enterprises $(15 \%)$.

Another strategy for stimulating the return or retention of Romanian workers, particularly highly specialised workers, is related to successful foreign investment in Romania, as, for example, in the automotive industry. The development of a Renault research centre near Bucharest, and a new Ford car factory in Craiova involved the implementation of training programmes, temporary work experience abroad for Romanian specialists, and a solid transfer of their knowledge and practice to the domestic market. Also, thanks to a qualified workforce and a dynamic business environment, big IT companies choose Romania as a base for their regional centres covering South-East Europe.

Former Romanian emigrants may act as agents of economic growth also by transferring knowledge and skills pertaining to the development and implementation of EU-funded projects, ${ }^{7}$ or by establishing the necessary contacts to build transnational partnerships.

\section{Diversified public interventions}

The EU Public Employment Services (PES). A key source of information and support for potential return migrants is the EURES network (of which Romanian PES is a part). Institutional development projects were implemented to improve coverage of clients (especially jobseekers from Romania). PES experts and specialised websites provide information on living and working conditions in Romania and other European community countries. It can be a challenge for PES to inform job-seekers of opportunities in other countries, even when the job-seekers are originally from another European country. Collaboration among PES can be further fostered (see Box 6.3. for an example of one such project).

\section{Box 6.3. The MEDIT project}

The MEDIT project was initiated by the Romanian Agency for Employment (Public Employment Service) in co-operation with Italia Lavoro (Veneto region). Developed during 2009-11, the project was co-funded by the European Social Fund. Its aim was to create a model of transnational co-operation for the return of Romanian migrants through the development of tools to inform Romanian migrants in Italy on the situation in Romania, and through the enhancement of local Romanian institutions' ability to support Romanian return migrants once they decide to return.

Immigration policy. In its National Immigration Strategy, Romania identified the following challenges for 2011-14: a) registered labour shortages in certain economic sectors/occupations due to massive emigration of Romanian workers; and b) European interest in using immigration as a possible measure to counteract the negative social and economic effects of an ageing population. The Romanian Government has already 
introduced changes in the conditions applied to work and residence permits, to facilitate the attraction and retention ${ }^{8}$ of highly skilled workers.

Maintaining cultural ties. Given the considerable size of Romanian communities abroad, another important strategy involves maintaining and strengthening cultural ties with these communities, and especially with the children of emigrants. ${ }^{9}$ In 1995 , The Romanian Government established the Department for Romanians Abroad ${ }^{10}$ to develop and implement Romanian diaspora policies. The Department ${ }^{11}$ focuses on:

- fostering of contacts between Romanian public figures and organisations from the diaspora and the institutions of the Romanian state

- $\quad$ increasing co-operation to support consolidation of EU membership

- promoting Romanian cultural values and strengthening bilateral relations between Romania and migrants' countries of destination.

The Government's Department for Romanians Abroad provides financial support for Romanian language courses in countries with large Romanian communities (see Box 6.4). It also promotes an online Romanian language course. ${ }^{12}$ In addition, the Ministry of Education, Research, Youth and Sports in Romania has organised Romanian language, culture and civilisation courses for teachers from Romanian communities abroad (such courses are given in numerous Italian regions, for example, based on a 2007 bilateral agreement with the Italian Ministry of Education).

\section{Box 6.4. Romanian language and civilisation courses}

The Government's Department for Romanians Abroad provides financial support, on a project basis, for Romanian language, culture and civilisation courses. The following are examples of projects already implemented:

- "Romanian school for second generation migrants - IV" - aiming at teaching Romanian language, history and geography, and providing support for the young generation of Romanian citizens in Spain (implemented by Association ARIPI).

- "Introduction to Romanian language, culture and civilisation" - providing Romanian courses (language and civilisation) to employees of the Spanish administrative system who interact with Romanian migrants (e.g., police, social services, health care and education institutions). The project has facilitated communication between Spanish administration employees and Romanian migrants (implemented by the Federation of Romanian Associations in Spain - FEDROM).

\section{Policy implications}

Substantial migration flows entail risks and opportunities, and intra-EU work mobility is no exception. A crucial question is how national and EU policies respond to this challenge.

In the case of Romania, migrants can act as "catalysts for the transformation of the Romanian society and for the convergence of Romanian values and lifestyles towards European ones" (Prelipceanu, 2008). This is especially true for the rural areas of Romania. Mass emigration emerged abruptly, however, destabilising the domestic labour market, and was marked by a distinct pattern based on individual initiative and community networks. Adequate policies (especially policies aimed at efficiently 
matching supply and demand on the domestic labour market) have therefore been difficult to implement. Migration management should constitute a key element in Romania's new strategic framework for employment (currently under drafting). Temporary migration schemes and support for reintegration into the domestic labour market should be envisaged.

An important issue is the limited availability of data to guide policy decisions, in light of the growing influence of Romanian migration on demography, social protection (e.g. the sustainability of the public pension system), education, training, employment (especially labour shortages) etc.

Romania continues to suffer from low employment $\left(58.5 \%{ }^{13}\right)$, high unemployment among youth $\left(23.7 \%{ }^{14}\right)$, and high in-work poverty (about $19 \%$ ). Wages remain considerably lower than in destination countries. This suggests that Romania will continue to be mainly a migrant-sending country, with a low propensity for return, at least in the short and medium term. Moreover, outmigration occurs in the context of accumulated labour shortages, especially in the health care sector, coupled with an ageing and rather economically inactive population. ${ }^{15}$ Effective migration management should be high on any political agenda related to employment, human resources development and social protection.

During the past decade, despite the effects of the economic crisis since 2008, Romania showed a constant trend towards convergence with the EU average in terms of GDP, productivity and sector distribution of the economy. Regional disparities still mark Romania and they partly explain the high propensity for migration in certain geographic regions (North-East, South-West, rural areas).

Romania does not lack opportunities for economic development and job growth, especially in sectors where development disparities between Romania and other EU countries are highest (transport infrastructure, construction, agriculture, alternative energy production) - sectors that match the skills of Romanian emigrants. Through effective employment and economic policies combined with information campaigns among Romanians abroad, these development opportunities could be used to stimulate and facilitate migrant return and integration.

\section{Conclusion}

Emigration has been largely for employment and has involved working-age individuals, so the initial benefits in terms of alleviating unemployment are counterbalanced by negative demographic effects, labour shortages, remittance-related inflation, and a range of social implications. These effects are particularly intense in certain regions. By now, the characteristics of Romanian emigration are known, as is the distribution of emigrants, although greater detail will help direct future policies to support return from employment abroad to activity in Romania. Public intervention to foster return has not led to large scale return, and much will depend on future growth prospects and on informing Romanians abroad of these prospects. 


\section{Notes}

1. Population and Housing Census 2011 - Final Results, National Statistics Institute, Romania (www.recensamantromania.ro/rezultate-2/).

2. Press Release on Population and Housing Censuses 2011 (14 December 2012), National Statistics Institute, Spain (www.ine.es/en/prensa/np756 en.pdf).

3. Foreign resident population on 1st January - focus on citizenship (data extracted), National Statistics Institute, Italy.

4. The increase in the unemployment rate in late 2008 and throughout 2009 diverted the attention of public policy makers towards the domestic labour market and the effects of the economic crisis.

5. The implementation of this plan has never been evaluated, possibly due to the negative impact of the economic crisis on the domestic labour market and the change of government in 2009.

6. Examples of such associations/organisations of Romanian students abroad are available on $\mathrm{http} / / /$ washington.mae.ro/node/288 and www.lsrs.ro/.

7. Italy and Spain are well-experienced users of EU-funded programmes.

8. Romania is mainly a transition country for migrants on their way to Western Europe.

9. In 2007, the Spanish Ministry of Education, with the support of the Romanian Language Institute, decided to introduce Romanian language and civilisation courses in the Spanish public colleges. Over 350 schools have included, in their extracurricular programme, an optional course of Romanian language, culture and civilisation.

10. The Department functioned under the direct authority of the Prime Minister and, since January 2013, it is part of the Ministry for Foreign Affairs.

11. The main programmes funded by the Department for Romanians Abroad focus on culture, mass-media, education, spirituality and tradition. The total staff of this institution is 30 employees.

12. www.dprp.gov.ro/about-us/education/ and www.dprp.gov.ro/elearning/.

13. Age group 15-64 (Labour Force Survey 2011, National Statistics Institute).

14. Age group 15-24 (Labour Force Survey 2011, National Statistics Institute).

15. In 2011, according to the National Statistic Institute 2011 Labour Force Survey, the economic dependency rate was 1340 per 1000 . 


\section{References}

Alexe, I. (2011), "The Fourth Wave. The Brain Drain Along the Route Between Romania-The West", Soros Foundation Romania.

Ambrosini, J.W., K. Mayr, G. Peri and D. Radu (2011), "The Selection of Migrants and Returnees: Evidence from Romania and Implications", National Bureau of Economic Research Working Paper, No. 16912, www.nber.org/papers/w16912

Barcevičius, E., K. Iglicka, D. Repečkaitè and D. Žvalionytė (2012), “Labour Mobility Within the EU: The Impact of Return Migration", European Foundation for the Improvement of Living and Working Conditions.

Ciuca, V., S. Pirciog, A.M. Zamfir and C. Mocanuna (2007), "Trends and Prognoses on the Phenomenon of Migration for Work at International and National Level", National Institute for Scientific Research in the Field of Labour and Social Protection.

Daniela-Luminita, C. (2004), "Migration Phenomenon from the Perspective of Romania's Accession to the EU", European Institute of Romania.

European Commission (2011a), "Report from the Commission to the Council on the Functioning of the Transitional Arrangements on Free Movement of Workers from Bulgaria and Romania".

European Commission (2011b), "Special Eurobarometer 337. Geographical and Labour Market Mobility".

European Commission (2010), Europe 2020. A Strategy for Smart, Sustainable and Inclusive Growth.

Eurostat (2011), "Migrants in Europe. A Statistical Portrait of the First and Second Generation", Eurostat Statistical Books Collection.

Ferri, A. and S. Rainero (eds.) (2010), "European Union and Return Migration Policies: The Case of Romanian Migrants".

Government of Romania (2011), "National Strategy on Immigration (2011-2014)”.

Government of Romania (2008), "Government Decision No. 187/2008 for the Approval of the Plan of Action on the Return of Romanian Migrant Workers".

Holland, D., T. Fic, A. Rincon-Aznar, L. Stokes and P. Paluchowski (2011), "Labour Mobility Within the EU -The Impact of Enlargement and the Functioning of the Transitional Arrangements", Final Report, National Institute of Economic and Social Research.

Hönekopp, E. and H. Mattila (eds.) (2008), "Permanent or Circular Migration? Policy Choices to Address Demographic Decline and Labour Shortages in Europe", International Organization for Migration (IOM). 
IOM - International Organization for Migration (2008), "Migration in Romania: A Country Profile 2008".

Makara, E., F. Csatári, J. Juhász, P. Makara and Panta Rhei Social Research Group (2011), "New Mobility Trends in Europe. A Preliminary Analysis for Further Research", European Foundation for the Improvement of Living and Working Conditions.

Marcu, S. (2011), "Romanian Migration to the Community of Madrid (Spain): Patterns of Mobility and Return", International Journal of Population Research.

National Statistics Institute Romania (2012), "Population and Housing Census 2011 final results".

National Statistics Institute Romania (2011a), Statistical Yearbook 2011, Romania.

National Statistics Institute Romania (2011b), "Labour Force Survey - 2011 Results”, Press Release.

National Statistics Institute, Spain (2012), "Population and Housing Censuses 2011", Press Release, December.

National Statistics Institute, Italy, Data extracted - Foreign resident population on 1st January - focus on citizenship.

OECD (2009), International Migration and the Economic Crisis: Understanding the Links and Shaping Policy Responses, OECD Publishing, Paris, dx.doi.org/10.1787/ migr outlook-2009-3-en.

Pasnicu, D. (2012), "Designing an Integrated Management System of the Migration Flows of Workers with a View to Manage Appropriate Economic Migration", National Institute for Scientific Research in the Field of Labour and Social Protection.

Pîrciog, S., V. Ciucă and E. Blaga (2006), "Evolution of Occupations on Romanian Labor Market in 2010 Perspective", National Institute for Scientific Research in the Field of Labour and Social Protection \& Ministry of Labour Family and Social Protection.

Prelipceanu, R. (2008), “The New Migration Patterns of Educated Romanians to EU: What Challenges for the Individuals and for the Nation-state", Romanian Journal of European Affairs, Vol. 8, No. 4.

Sandu, D. (2006), "Living Abroad on a Temporary Basis. The Economic Migration of Romanians 1990-2006", Soros Foundation Romania.

Shima, I. (2010), "Return Migration and Labour Market Outcomes of the Returnees. Does the Return Really Pay Off? The Case-study of Romania and Bulgaria, Forschungsschwerpunkt Internationale Wirtschaft (FIW).

Soros Foundation Romania (2011), "Maximizing the Development Impact of Migration”. 



\section{ORGANISATION FOR ECONOMIC CO-OPERATION AND DEVELOPMENT}

The OECD is a unique forum where governments work together to address the economic, social and environmental challenges of globalisation. The OECD is also at the forefront of efforts to understand and to help governments respond to new developments and concerns, such as corporate governance, the information economy and the challenges of an ageing population. The Organisation provides a setting where governments can compare policy experiences, seek answers to common problems, identify good practice and work to co-ordinate domestic and international policies.

The OECD member countries are: Australia, Austria, Belgium, Canada, Chile, the Czech Republic, Denmark, Estonia, Finland, France, Germany, Greece, Hungary, Iceland, Ireland, Israel, Italy, Japan, Korea, Luxembourg, Mexico, the Netherlands, New Zealand, Norway, Poland, Portugal, the Slovak Republic, Slovenia, Spain, Sweden, Switzerland, Turkey, the United Kingdom and the United States. The European Union takes part in the work of the OECD.

OECD Publishing disseminates widely the results of the Organisation's statistics gathering and research on economic, social and environmental issues, as well as the conventions, guidelines and standards agreed by its members. 


\section{Coping with Emigration in Baltic and East European Countries}

The Baltic countries have experienced sustained emigration over the past decade, contributing to population decline and a loss of working-age population. The impact of this emigration is felt strongly in the labour market, the general economy and in social developments. How can countries deal with the impact of high levels of emigration? How to attract back emigrants? How best to benefit from the financial, social and human capital developed abroad? The Baltic countries are not alone in addressing these challenges, and this volume brings together the recent experience of Poland and Romania, as well as a wide range of OECD countries, in developing new policies to cope with emigration.

\section{Contents}

Executive summary

Chapter 1. Emigration from the Baltic States: Economic impact and policy implications

Chapter 2. Emigration from Estonia: Recent trends and economic impact

Chapter 3. The social and economic impact of emigration on Lithuania

Chapter 4. Emigration from Latvia: Recent trends and economic impact

Chapter 5. Matching the skills of return migrants to labour market needs in Poland

Chapter 6. Mobilising migrants skills and resources in Romania

Consult this publication on line at http://dx.doi.org/10.1787/9789264204928-en.

This work is published on the OECD iLibrary, which gathers all OECD books, periodicals and statistical databases. Visit www.oecd-ilibrary.org for more information. 